UNIVERSIDADE DE SÃO PAULO

FACULDADE DE FILOSOFIA, LETRAS E CIÊNCIAS HUMANAS

DEPARTAMENTO DE LETRAS ORIENTAIS

PÓS-GRADUAÇÃO EM LITERATURA E CULTURA RUSSA

\title{
O MÉTODO DE ANÁLISE ATIVA DE K. STANISLÁVSKI COMO BASE \\ PARA A LEITURA DO TEXTO E DA CRIAÇÃO DO ESPETÁCULO \\ PELO DIRETOR E ATOR
}

Nair Dagostini

\begin{abstract}
Tese apresentada ao Programa de PósGraduação em Literatura e Cultura Russa, do Departamento de Letras Orientais Faculdade de Filosofia, Letras e Ciências Humanas da Universidade de São Paulo, para obtenção do título de Doutor em Letras.
\end{abstract}

Orientadora: Prof ${ }^{\mathrm{a}}$. Dr ${ }^{\mathrm{a}}$. Arlete Orlando Cavaliere

São Paulo 


\section{DEDICATÓRIA}
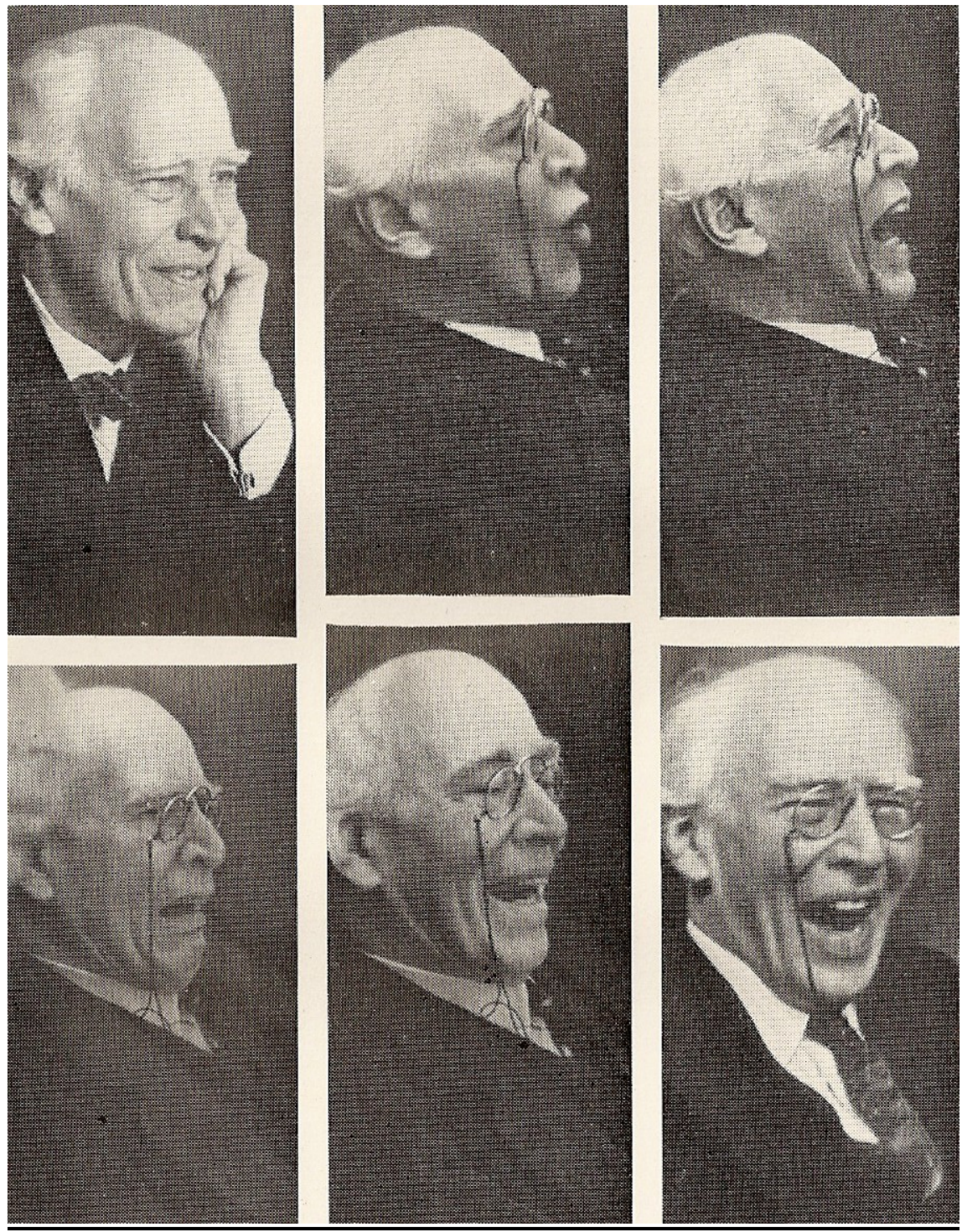

1935-1936

A mim, ainda me resta viver dois, três anos, os últimos. O que eu devo fazer é transmitir minha experiência e método para quem quiser recebê-los. Peguem, eu darei tudo o que sei.

Konstantin Stanislávski

Dedico a tese in memoriam aos meus mestres Tovstonógov e Katsman. 


\section{AGRADECIMENTOS}

Agradeço à minha orientadora, prof ${ }^{\mathrm{a}}$. $\mathrm{dr}^{\mathrm{a}}$. Arlete Orlando Cavaliere pelo estímulo e confiança proporcionados durante o processo de realização desta tese.

Aos professores integrantes da banca de qualificação, prof ${ }^{a}$. dra . Elena Vássina e prof $f^{a}$. dra. Maria Silvia Betti, pelas valiosas sugestões, os novos olhares e caminhos apontados.

À prof ${ }^{\mathrm{a}}$. dr ${ }^{\mathrm{a}}$. Elena Vássina, a quem ficarei eternamente grata por ter proporcionado as condições para a realização desta tese, colocando à disposição sua biblioteca, seu conhecimento e sua generosidade ímpar.

Em especial, aos meus atores-pesquisadores, que, apesar de todos os conflitos, estiveram comprometidos até o final com a pesquisa e criação do espetáculo: Cristiane Werlang, Gustavo Muller, Luana Michelottti, Maria Andréa Soares, Michele Zaltron, Rafael Sieg.

À equipe artística do espetáculo A Dócil - Risomá Cordeiro, Nara Maia, Cléber Laguna, Nelson Magalhães, Leandro Bartz, Sandra Tartas.

Ao Celso e ao Jorge, pela amizade e força incondicionais

Ao Emílio, pela leitura da adaptação, sugestões, poesias e amizade.

À Luana e Camilo, pela ajuda no italiano e no inglês.

À Klara Gurianova, pela generosidade em ajudar a sanar dúvidas da língua russa, da bibliografia e dos autores.

À Iara, pela atenta revisão.

À Irina Mikhailovna, pelas leituras, afeto e amizade.

À Maria Helena Lopes, pela amizade e discussões por telefone nos momentos críticos.

À Martina, pelos desabafos, leituras, opiniões e amizade.

À Márcia, Cléber, Adi, Adriane e Camilo, pela acolhida e amizade.

À Michele, pela ajuda, sugestões e amizade.

Ao Rafael, pela sua incondicional dedicação e disponibilidade na concretização desta tese, pela paciência e discussões.

Aos meus ex-colegas do Departamento de Artes Cênicas da UFSM e a todos os meus alunos que cooperaram para o amadurecimento destas reflexões ao longo dos anos.

A Tatiana Golscheva, pelos vídeos, CDs e bibliografia trazidos da Rússia, pela amizade, presença e transmissão de canções russas às atrizes. 
À minha família: à Adriana e Mauro pela disponibilidade, ajuda e afeto: ao Gil pela àgua nas flores e reuniões do condomínio; à Lourdes e Rosa, pelas caminhadas e conversas; ao Miguel e Geraldine, pelos momentos lúdicos e de descontração; à Ruth, pelo afeto e incondicional apoio; à minha querida mãe, pelas orações e pela espera, e a todos os que de alguma forma me apoiaram para a realização desse trabalho. 


\section{RESUMO}

A orientação deste estudo se dá na perspectiva de investigar, definir e especificar dentro do “sistema” de K. Stanislávski o método de análise ativa e o das ações físicas juntamente com os seus elementos constitutivos a partir das suas fontes primárias, teóricas e práticas, e do seu desenvolvimento por renomados diretores russos, que escreveram e aplicaram o método em suas criações. Obedecendo à coerência dos princípios metodológicos do "sistema”, esse trabalho contém uma parte teórica e outra prática. Na teórica, procuramos esclarecer em que consiste o método; especificar o processo de conhecimento da vida da obra, a criação do romance da vida das personagens por parte do diretor; os elementos necessários para a leitura da obra através da ação; o método de análise ativa e seus elementos estruturais; os elementos do "sistema” para o ator criativo, acompanhado da tradução de estenogramas das aulasensaios de K. Stanislávski sobre seus últimos experimentos relativos ao método das ações físicas. A aplicação do método se deu sobre a obra “A Dócil”, de Dostoiévski. Nela, primeiramente, foi realizada uma análise na busca de conhecê-la. Em seguida foi feita a transposição do texto literário para o texto teatral, o que resultou na adaptação e análise da ação da mesma, que se constitui no sistema do espetáculo, o qual interliga o projeto artístico do autor com o do diretor e se concretiza pela ação cênica do ator.

Palavras-chave: Sistema de Stanislávski/Análise Ativa, Autor/Diretor/Ator, “A Dócil”, de Dostoiévski, Criação teatral. 


\begin{abstract}
The present study intends to investigate, define and specify the following methods, which are part of K. Stanislavski' System: the Active Analysis and the Physical Actions with its elements. It is taken from the practical and theoretical primaries sources and also from its development through renowned Russian directors that have written and applied the method in their creations. Obeying the coherence of the methodological principles of the "system", this work has a theoretical and a practical part. In the theoretical one, we look for clarifying in what the method consists; specifying the process of knowing the text's life through the director's hands. We also search for the necessary elements to read the text through the action; the method of active analysis and its structural elements; the_elements of the "system” to the creative actor, followed by the translation of the notes from the rehearsal-classes of K. Stanislavski, about his last experiments related to the method of Physical Actions. The method was applied in the text: “A Dócil”, of Dostoiévski. First of all, this text was analyzed with the purpose of being deeper understood. After that, a transposition from the literary to theatrical text was done and we had as a result the adaptation of the text and its action's analysis. This adaptation constitutes itself the own system and is responsible for connecting the artistic project of the author with one of the director and that is materialized through the scenic action of the actor.
\end{abstract}

Keywords: Stanislavski’ System/Active Analysis, Author/ Director/ Actor, “A Dócil”, of Dostoievski, Theatrical Creation. 


\section{SUMÁRIO}

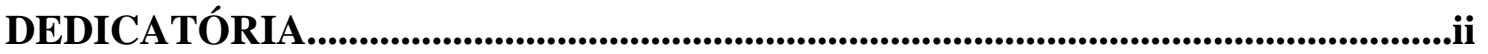

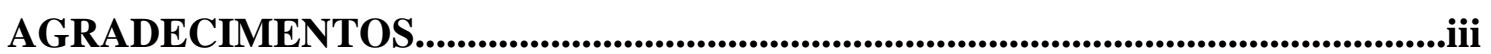

RESUMO..............................................................................................................................................V

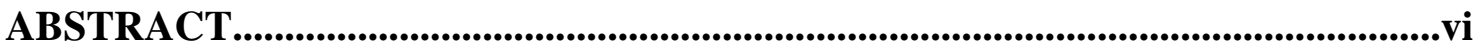

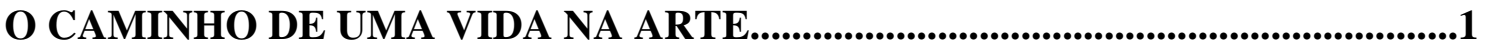

CAPÍTULO I - O estudo dos princípios de direção cênica na leitura do texto a partir do método de análise ativa............................................................................................22

1. Elementos do "sistema” para a análise do texto............................................26

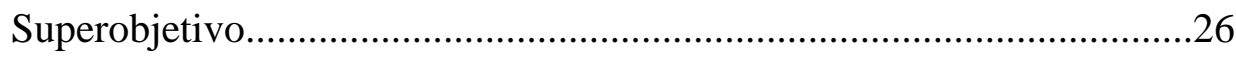

Linha transversal de ação.....................................................................31

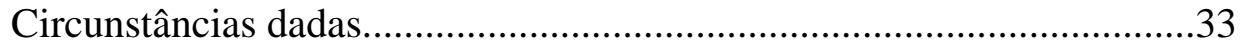

2. O trabalho do diretor no processo de conhecimento da vida da obra...............35

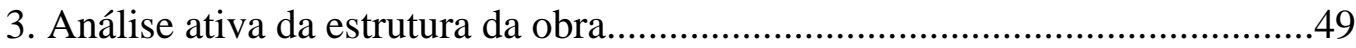

CAPÍTULO II - Elementos do "sistema" e a últimas investigações de K. Stanislávski com o método das ações físicas sobre o papel.........................................................58

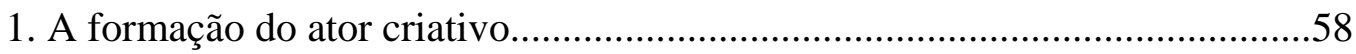

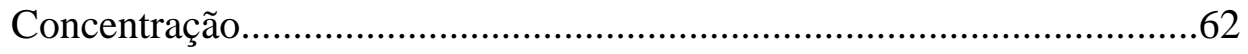

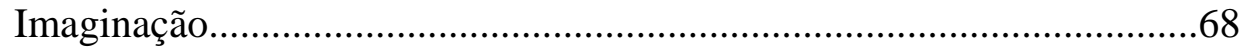

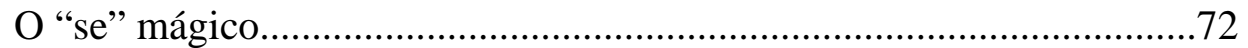

Fé e sentido da verdade..........................................................................73

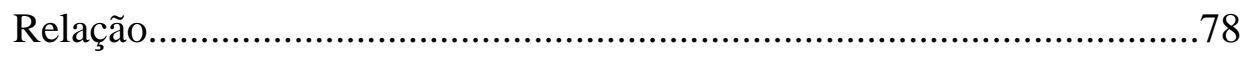

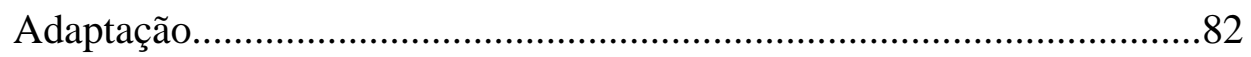

Liberdade muscular..............................................................................84

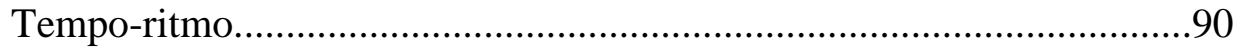

2. As últimas experiências de K. Stanislávski no Estúdio de Ópera

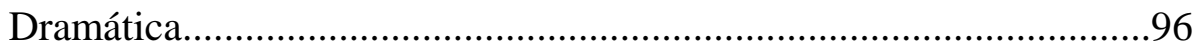

Tradução dos estenogramas das aulas-ensaios sobre o papel de Hamlet. 102 
CAPÍTULO III - Aproximação à análise de alguns aspectos da Imagem Artística na

Novela “Krotkaia” (A Dócil), de Fiódor M. Dostoievski...............................................145

1. Impressões sobre a Novela A Dócil.............................................................145

2. A Imagem Artística da Novela A Dócil.....................................................153

O Espaço Artístico.............................................................................161

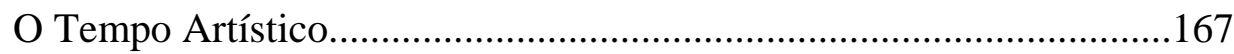

As oscilações na mentalidade dos heróis..............................................173

CAPÍtulo IV - Adaptação e Análise Ativa de A Dócil, de Fiódor M.

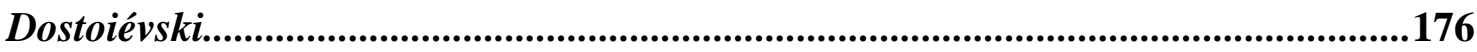

1. Adaptação da Novela “Krotkaia” (A Dócil)...............................................176

2. Análise Ativa da adaptação da narrativa de A Dócil.....................................203

3. Análise Ativa dos grandes acontecimentos da adaptação de A Dócil............204

4. Análise Ativa dos acontecimentos seqüenciais da adaptação de A Dócil......206

DA AÇÃO AO ESPETÁCULO.........................................................................225

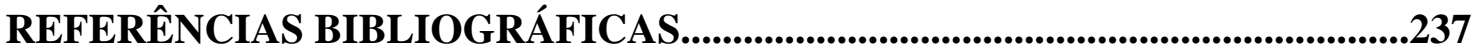

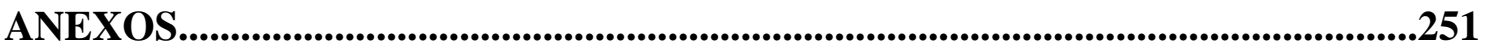




\section{O CAMINHO DE UMA VIDA NA ARTE}

Preservar a herança de Stanislávski - isso significa desenvolvê-la. ${ }^{1}$

O que será exposto, nesta parte inicial, é a trajetória de minha definição acadêmica e artística na área da arte teatral, as influências recebidas e a atividade como professora, pesquisadora e artista das artes cênicas.

Em 2001, com a defesa da dissertação de mestrado em Filosofia Mímesis de Práxis como Eudaimonia: Aristóteles e Lukács, pela Universidade Federal de Santa Maria, também encerrei a minha atividade acadêmica nesta instituição como professora do Curso de Artes Cênicas. A decisão de concorrer a uma vaga de doutorado na FFLHC/USP poderia erroneamente parecer uma questão de vaidade, já que o título não seria incorporado na ascensão da carreira. O que, então, me levaria a passar pelo processo de concretização de uma tese, que sempre envolve desafios e paixões, mas também certo desgaste e até sofrimento? Acredito que foi a constatação de não ter efetuado o registro de um conhecimento adquirido com grandes mestres da arte teatral num país que deu, no século XX, ao Ocidente, o maior legado nessa área através da figura incomparável de Konstantin Serguiêievitch Stanislávski -Alexéiev (1863-1938).

Esse conhecimento se refere ao seu "sistema", que me serviu de base e me guiou ao longo do percurso acadêmico-artístico. Essa dívida estava pendente devido ao envolvimento total com atividades de ensino, pesquisa e extensão dentro do curso em que atuei. Uma parte estava cumprida com a transmissão desse conhecimento via direta, nas aulas e orientações aos alunos, que hoje somam mais de uma centena espalhados pelo Brasil.

Mas, apesar desse conhecimento transmitido estar sendo aplicado e se expandindo em diferentes atividades artísticas, pedagógicas e culturais, penso que ainda é em pequena escala, pois os equívocos e mal-entendidos sobre o "sistema" ainda existem, e, em certa medida, sempre existirão. Constata-se a necessidade de se apossar individualmente desse saber através da prática, sobretudo, sendo que a sensibilidade e a capacidade de cada um fazem com que a peculiaridade subjetiva sempre esteja presente, em detrimento da objetividade do "sistema” e de suas leis.

O importante é a honestidade e a seriedade com que nos aproximamos e nos apoderamos de determinado conhecimento e a nossa atitude diante dele, encarando-o

\footnotetext{
${ }^{1}$ KEDROV, M. N. Stat'i, retchi (Ensaios e discursos). Moscou: VTO, 1978, p.51.
} 
como um valioso patrimônio produzido por nossos antecessores o qual temos a obrigação de preservar e de desenvolver para a transformação de nossas potencialidades artísticas, culturais e humanas.

Eugênio Kusnet (1898-1975) deixou para nós, brasileiros, o legado valioso de sua experiência pessoal sobre o "sistema”, como mestre, diretor, ator e escritor. No último período de sua vida, adquiriu em Moscou, dos discípulos de K. Stanislávski, o método de análise ativa. Com esse olhar renovado sobre o "sistema", empenhou-se para que muitos dos mal-entendidos produzidos, até por ele mesmo, em sua atividade artístico-pedagógica, fossem sanados e, em seus últimos anos de vida, além de promover a formação de professores, diretores e atores, escreveu o livro "Ator e Método”. Penso que, apesar de já se completarem 30 anos de sua morte, a sua constatação ainda possui certa validade:

Infelizmente, no Brasil nunca tivemos a oportunidade de confirmar esse método no trabalho cotidiano de nosso teatro. [...] os nossos diretores, sempre dispostos a fazer novas experiências, desistiram, por força de certas circunstâncias, até da própria 'Análise Ativa'.'

O impulso que me levou a realizar esse estudo não foi a pretensão de possuir a melhor verdade sobre o "sistema", por tê-lo recebido na fonte direta, mas, como já disse, foi a de fazer uma reflexão sobre a minha trajetória artística e acadêmica, com base num conhecimento adquirido com grandes mestres, herdeiros da tradição de K. Stanislávski, mas que foi assimilado e aplicado por mim dentro de determinadas peculiaridades artístico-pessoais.

Por outro lado, estou ciente da falta de informação e de acesso a muitos escritos do mestre publicados nos últimos anos na Rússia, como também de boas traduções diretas do russo, que possam desfazer muitos falsos pressupostos reinantes sobre o “sistema”, a fim de ser possível aprofundar e até contribuir para o seu desenvolvimento em muitos aspectos. Penso estar dando uma modesta contribuição relativamente ao “sistema” de K. Stanislávski, sobretudo no que tange a seu último período, o método de análise ativa, aos profissionais do teatro no Brasil, a partir do inesgotável material escrito que o mestre nos deixou, como nos dizem Arlete Cavaliere e Elena Vássina ${ }^{3}$ :

\footnotetext{
${ }^{2}$ KUSNET, E. Ator e Método. São Paulo: Hucitec; Rio de Janeiro: Funarte, 2003, p.150.

${ }^{3}$ Professoras Doutoras do Departamento de Literatura e Cultura Russa da FFLCH-USP.
} 
Stanislávski escreveu muito, e seu famoso 'sistema', que ele buscou aprofundar e aperfeiçoar até o final da vida, para a consecução de um grande projeto integrador, através do qual toda a sua experiência, enquanto ator, diretor e pedagogo, pudesse ser registrada, segundo uma perspectiva de conjunto, jamais foi concluído. ${ }^{4}$

Feita essa observação, passarei a dar uma perspectiva de minha formação e atividade nas Artes Cênicas.

Concluí o Bacharelado em Direção Teatral e Licenciatura em Arte Dramática na Universidade Federal do Rio Grande do Sul/UFRGS, em julho de 1978. Como diretora, no período de formação, destaco duas montagens: Os Fuzis da Senhora Carrar, de Bertold Brecht (1898-1956), e Senhorita Júlia, de August Strindberg (18481912). E, como atriz, também destaco a atuação no papel da "Mãe”, na peça $O$ MalEntendido, de Albert Camus (1913-1960), e no de “Isadora”, no texto dramático O Encontro no Bar, de Bráulio Pedroso (1931-1990).

À medida que se aproximava o término da faculdade, apareciam os questionamentos sobre o que fazer para continuar a desenvolver minha trajetória artística. Essas inquietações me levaram a encaminhar dois projetos com pedidos de solicitação de bolsas de estudos, um junto à Embaixada da URSS, na área de cinema, e o outro junto à Embaixada da Polônia, na área de teatro. Em setembro de 1978, fui contemplada com as duas bolsas de estudos, uma para o Curso de Artes Dramáticas, na Universidade Jagiellonica, em Cracóvia, e a outra na URSS. Optei por transferir a ida à Polônia para depois do término da bolsa da URSS, que seria, em princípio, de dois anos.

Em 30 de setembro de 1978, cheguei a Moscou, sem saber ao certo onde estudaria e em que área, teatro ou cinema, esta última de acordo com minha solicitação. Lá chegando, com o primeiro dia de neve, sem falar minimamente a língua, me vi entre milhares de estudantes estrangeiros. Após uma noite em Moscou, fui enviada pelo Ministério de Educação da URSS à cidade de Leningrado, hoje São Petersburgo. A viagem de trem rumo ao desconhecido, com dois estudantes, um árabe e outro indiano, sem comunicação verbal, já que não tínhamos uma língua comum que permitisse manter a mínima conversação, a não ser a mimética, anunciava o que estaria por vir.

\footnotetext{
${ }^{4}$ CAVALIERE, A; VÁSSINA, E. A herança de Stanislávski no teatro norte-americano: caminhos e descaminhos. In Crop. Theater Studies -.Guest Editor. Maria Silvia Betti. São Paulo: Humanitas FFLCH/USP . Número 7, p. 1-394, 2001, p.308.
} 
Na chegada à estação, fomos recebidos por responsáveis pelos estrangeiros e enviados às instituições destinadas a cada um de nós. Conduziram-me ao LGITMiK Instituto Estatal de Teatro, Música e Cinema de Leningrado, denominado N.K. Cherkacov. ${ }^{5}$ Fui a primeira brasileira a estudar no Instituto, onde ninguém falava a língua portuguesa. Tive, então, a impressão de pertencer a uma tribo totalmente desconhecida no mundo. Ao conseguir explicar que entendia o espanhol, trouxeram um doutorando cubano para me auxiliar. Nos primeiros três meses, estive envolvida, sobretudo, com a aprendizagem da língua russa, priorizando a comunicação imediata.

Vencidos os primeiros obstáculos com o idioma e com a adaptação, pois o inverno na virada do ano chegou a 43 graus negativos, passei a assistir às aulas de direção e interpretação, estas obrigatórias, pois as disciplinas referentes às práticas corporais oferecidas na Instituição e de cunho teórico eram de minha livre escolha.

A instituição determinou, diante da análise de meu currículo, que faria a pósgraduação (aspirantura) em "Maestria do Ator Dramático”, no curso de Arkadii Katsman (1921-1989), e em “Direção Dramática”, no curso de Gueorgui Tovstonógov (1913-1988). Ambos os cursos em nível de graduação, sendo que o de "Maestria do Ator Dramático” tinha duração de quatro anos, e o de “Direção Dramática”, de cinco.

Esses cursos só admitiam nova turma após os alunos ingressantes terem concluído o curso. Para o ingresso, os candidatos passavam por uma rigorosa seleção, submetendo-se a testes específicos, práticos e teóricos. Em "Maestria do Ator Dramático”, eram admitidos 22 alunos, sendo 11 mulheres e 11 homens; no curso de “Direção Dramática” esse não era o critério adotado, e o grupo, além de ser menor, apresentava predominância de alunos homens.

Ambos os cursos, atuação e direção, eram muito disputados pela notabilidade de seus professores principais, professor Katsman e professor Tovstonógov. Todos os demais professores assistentes na cátedra de maestria do ator e de direção teatral eram subordinados ao pedagogo principal, que tinha a função de uma espécie de guia, de orientador responsável pela formação profissional dos atores e diretores. Essa forma de organização curricular levava a formação de um coletivo muito forte, guiado pelo mestre principal. O que era destacado nesse sistema de ensino, além da qualidade da Instituição, era, sobretudo, o curso com determinado mestre, o que se assemelhava

\footnotetext{
${ }^{5}$ O LGITMiK em 1993 passou a denominar-se Academia Estatal de Arte Teatral de São Petersburgo SPGATI.
} 
muito à estrutura dos Estúdios criados por K. Stanislávski, principalmente, ao último, o Estúdio de Ópera Dramática. ${ }^{6}$

Seguem-se algumas referências sobre os dois grandes mestres com os quais tive o privilégio de estudar.

Arkadii Katsman formou-se como ator no Instituto LGITMiK, na época da Segunda Guerra Mundial, profissão que exerceu por muitos anos. Mas, ao assumir a responsabilidade do curso que levava o seu nome, passou a dedicar-se exclusivamente à formação dos estudantes desse curso, no papel de principal pedagogo e também de diretor responsável pelas montagens dos alunos do curso. Também ocupava o cargo de principal assistente de Gueorgui Tovstonógov no seu curso de “Direção Dramática”.

Nos anos de 1978-79, a turma de atores concluía a sua trajetória de estudos na arte do ator com o espetáculo, dirigido por Arkadii Katsman, Sonhos de uma noite de verão, de Shakespeare (1564-1616). Tive a oportunidade de assistir a uma parte do processo da criação desse espetáculo, apesar do obstáculo do escasso entendimento da língua russa. Com os alunos ingressantes no início do ano letivo de 1979, dirigiu, como trabalho final de formatura, o romance de Dostoiévski (1821-1881) Os Irmãos Karamásov. Nessa montagem só participei de parte do processo de criação, pois sua estréia ocorreu após minha volta ao Brasil. A peça tinha como meio principal de criação a improvisação de études (estudos). Faz-se necessário acrescentar que Lev Dodin (1944- ), internacionalmente reconhecido diretor teatral, era professor assistente nos cursos de Katsman e Tovstonógov, sendo que, com a morte de Arkadii Katsman, assume a cátedra do Curso de “Maestria do Ator Dramático”.

Gueorgui Tovstonógov, principal pedagogo do Curso de Direção Dramática, que levava o seu nome, fez sua formação como diretor no GITISa ${ }^{7}$, ingressante em 1933. Teve como pedagogos principais A. D. Popov (1892-1961), A. M. Lobanov (19001959) e M. O. Knébel (1898-1985), que também foi sua professora, mas não no papel de orientadora, ou seja, como pedagoga principal. Todos eles eram discípulos e seguidores de K. Stanislávski, e, além de terem sido atores do TAM, haviam participado como estudantes nos seus diversos Estúdios. Estes se constituíam em espaços que

\footnotetext{
${ }^{6}$ O Estúdio de Ópera Dramática de 1919 a 1926 funcionou na casa de K.S.Stanislávski, primeiramente na rua Karetni Riad e posteriormente na travessa Leóntiev. Em 1926, foi convertido em Teatro - Estúdio Estatal de Ópera Stanislávski. Em 1928, passou a chamar-se Teatro de Ópera Stanislávski. Em 1941, esse teatro fundiu-se com o Teatro Musical V.I. Nemiróvich-Dânchenko, sendo denominado Teatro Musical dos Artistas do Povo da URSS, K.S. Stanislávski e V.I. Nemiróvich-Dânchenko. Desde 1953, intitula-se Estúdio de Ópera Dramática K. Stanislávski.

${ }^{7}$ GITIS - Instituto Estatal de Arte Teatral de Moscou, de nome A.V.Lunatchrski. A partir de 1991 passa a chamar-se RATI - Academia Russa de Arte Teatral.
} 
funcionavam como laboratórios onde o mestre desenvolveu o seu "sistema", experimentou e explorou os princípios fundamentais do processo criativo da arte do ator com os estudantes.

Tovstonógov chegou a assistir a algumas palestras-aulas de K. Stanislávski no Estúdio de Ópera Dramática e a conferências no GITISa. Sofreu influência de Nemiróvitch-Dântchenko (1858-1943), Vartángov (1884-1924), Tairóv (1885-1950), Meyerhold (1874-1940) e Brecht, mas considerava-se filho da tradição stanislaviskiana, ou seja, discípulo do Teatro de Arte de Moscou, pois aprendeu com seus mestres o uso do "sistema" de Stanislávski e aplicou-o a partir do conhecimento adquirido com esses mestres e de sua vasta prática como pedagogo e diretor, mas de uma maneira muito pessoal.

Como artista, apesar de haver se adequado aos cânones do regime soviético, quanto às instituições, e de ter sido muito respeitado pelo regime, sempre usufruiu de muita liberdade em sua arte, a qual apresentava uma irreverência estética nãoconformista. Gueorgui Tovstonógov foi o principal diretor do Grande Teatro Dramático Gorki, de Leningrado (BDT), hoje com o nome de Grande Teatro Dramático Gueorgui Tovstonógov. Foi considerado um dos mais importantes diretores da encenação contemporânea, não só em seu país, mas internacionalmente.

Os seus espetáculos foram mostrados em temporadas pela Europa, Estados Unidos, América Latina, pelos países da Ásia e do Leste Europeu. Realizou inúmeras montagens nesse núcleo dos países socialistas. Para dar uma idéia resumida das suas grandes montagens, nomeio algumas entre mais de uma centena: As Três Irmãs e Tio Vânia, de Tchekhov (1860-1904), Baixos Fundos e Os Pequenos Burgueses, de Gorki (1868-1936), A História de um Cavalo e Ana Karénina, de Lev Tolstoi (1828-1910), O Inspetor Geral e Almas Mortas, de Gogol (1809-1852), A tragédia otimista, de V. Vichnevski (1900-1951), Henrique IV, de Shakespeare, Humilhados e Ofendidos e O Idiota, de Dostoiévski. Sobre este espetáculo há uma declaração de Eugênio Kusnet, que penso ser ilustrativa de sua grandiosidade artística, quando cita o genial ator I.M. Smoktunovski (1925-1994), no papel de príncipe Michkin: “Até agora, depois de muitos anos, ainda considero aquele espetáculo o melhor entre todos que vi na minha vida". ${ }^{8}$ Considerado um diretor altamente versátil, transitou por todo tipo de temas, gêneros e estilos. Foi mestre em criar cenas de grande tensão dramática.

\footnotetext{
${ }^{8}$ KUSNET, E. Ator e Método. São Paulo: Hucitec; Rio de Janeiro: Funarte, 2003, p.133.
} 
Tovstonógov dirigiu alguns filmes para televisão e escreveu inúmeros artigos e obras, sendo as mais conhecidas Zerkalo stseny (O espelho da cena), em dois tomos, Bessédy s kollegami (Conversa com os colegas) e Prem'éry (Estréias). O primeiro foi traduzido em várias línguas, o tomo I, com o nome de A Profissão do Diretor de Cena. Como diretor e pedagogo de alto nível intelectual e artístico, foi responsável pela formação de grandes gênios da cena russa, diretores e atores, muitos ainda em atividade e de reconhecimento público nacional e internacional. Entre os diretores conhecidos no Brasil que foram seus alunos, menciono Lev Dodin e Kama Guinkas (1941- ).

No curso de direção, Tovstonógov fazia-se presente duas vezes por semana, pela tarde, já que os ensaios no BDT eram pela manhã, sendo que a turma, no restante do tempo, ficava sob orientação do principal pedagogo assistente, Arkadii Katsman, e de seus respectivos pedagogos assistentes. Na esfera pedagógica do curso de direção, Tovstonógov e Katsman eram complementares, um não existia sem o outro, vale observar as datas de suas mortes, 1988 e 1989, respectivamente. Quando Tovstonógov chegava às aulas, era-lhe dedicada uma grande reverência, pois era considerado um diretor-pedagogo muito exigente, que paralisava a todos. Ao iniciar o trabalho com a apresentação de exercícios criativos preparados para o dia, os quais davam a dimensão daquilo que estava sendo trabalhado nas aulas, com os assistentes, na aquisição de técnicas referente aos elementos do "sistema" e à apresentação de études ou análise ativa dos textos, se instalava uma atmosfera descontraída e apaixonada, com calorosas discussões em que diferentes pontos de vista se contrapunham, não só entre alunos, mas entre os dois mestres. Dentro da sala de aula havia um clima de liberdade de expressão e de igualdade, em que dominavam o espírito ético e o entusiasmo artístico, tão essenciais no "sistema” de K. Stanislávski.

No coletivo de 1979, ingressantes do primeiro ano, nas aulas de maestria do ator, trabalhavam com o método das ações físicas, desenvolvendo os mais variados exercícios com objetos imaginários. Os elementos do sistema eram trabalhados por algumas horas diariamente. O trabalho criativo se dava, sobretudo, através de improvisações dos études, nos quais o aluno tinha que criar uma pequena cena com uma estrutura dramática que contemplasse as etapas exigidas, conforme o método de análise ativa, que será desenvolvido nos capítulos posteriores.

A matéria para a criação do étude devia ser resgatada da própria vivência do ator, de uma experiência pessoal, de sua memória emocional e de ações com que o aluno possuísse familiaridade. A imaginação entrava no momento da composição e 
organização do material e, sobretudo, na execução das ações físicas com objetos imaginários nas circunstâncias inventadas pelo aluno, dentro dos acontecimentos que compunham o étude. Esses eram elaborados individualmente e submetidos a uma criteriosa análise pelo mestre e professores assistentes. O aluno tinha que criar e apresentar, durante o semestre uma quantidade suficiente de études, para que os melhores fossem aperfeiçoados e apresentados em mostras no final do semestre. Nesses trabalhos, o objetivo principal das apresentações era avaliar o desenvolvimento do aluno em cada etapa de sua formação artística, pois aquele que não apresentasse as condições artísticas, disciplinares e éticas exigidas pelo curso seria eliminado do mesmo.

Toda aula com o mestre seguia um ritual rigoroso, uma espécie de "espetáculo" de uns 40 minutos, que se compunha de quatro momentos: zatchin, crônica, composição e popytka. O zatchin era um exercício criativo, espécie de prólogo, que aglutinava uma síntese dos elementos técnicos e teóricos que estavam sendo adquiridos na totalidade das disciplinas, que envolvia o coletivo, sob a "direção" de um dos alunos selecionado a priori. Nele era avaliado a escolha da linguagem artística e a sua coerência com o conteúdo apresentado, que, em geral, se tratava de habilidades de movimentos, gestos, ações, palavras e canções, tendo como fio condutor determinada idéia. Seguia-se a apresentação de uma crônica por um aluno também já selecionado, com resolução cênica adequada ao conteúdo, o qual devia estar ligado a algo que havia tocado o aluno, que podia ser no âmbito do curso, da rua, da realidade enfim, resultante de suas observações e impressões pessoais. Uma composição plástica a partir de um elemento fixo, a qual devia sugerir uma ação transcorrida que não fosse ilustrativa, mas se constituísse numa metáfora. E, por fim, a apresentação de uma “popytka”, uma forma de "etiqueta” criativa para apresentar uma bebida, oferecida aos professores (chá, suco, água, etc.).

No transcorrer da apresentação desses trabalhos, havia uma disciplina impecável, dentro de todos os requisitos necessários para a apresentação de um espetáculo. O professor principal, em conjunto com os demais professores, assistentes, alunos e "aspirantes” (alunos de pós-graduação) analisava cada exercício, tanto na forma quanto no conteúdo e sob o aspecto de sua coerência e lógica. Também eram destacados o humor na criação e a originalidade.

Essas aulas eram sempre assistidas por um público que se compunha de professores e artistas, visitantes nacionais e estrangeiros e dos "aspirantes”, em que eu 
me incluía. A seguir, eram mostrados os études individuais, que passavam por análise, discussões e eram retrabalhados nos aspectos considerados problemáticos. Quando os atores não possuíam études para apresentar, o mestre ou assistente trabalhava exercícios que envolviam os elementos do "sistema": atenção, imaginação, irradiação, jogos, pesquisa com animais, entre outras habilidades.

Se no primeiro semestre do ano ingressante a criação dos études devia estar ligada à experiência pessoal do aluno, já no segundo semestre a criação dos études iniciava-se a partir da literatura soviética, por estar mais próxima e pertencer ao seu universo cultural. Nessa etapa da criação dos études, havia a necessidade da relação com o partner e o desenvolvimento do conflito entre ambos. Os alunos deviam selecionar fragmentos da obra que possibilitassem o desenvolvimento dramático para a construção dos acontecimentos nas circunstâncias dadas na obra que contemplassem o processo de relação conflituosa e que dessem a idéia de totalidade. O texto, quando necessário, devia originar-se das próprias ações do ator dentro das circunstâncias da obra, prevalecendo o critério geral da criação, o "se”, gerado a partir da pergunta $O$ que eu faria em tais circunstâncias dadas?.

No segundo ano, o aluno passava a ter conhecimento teórico sobre o "sistema” e o método de análise ativa, com todos os elementos que a compõem. Na realidade o processo que se dava era uma reflexão sistematizada sobre a prática que já vinha sendo realizada e de certa forma em processo de desenvolvimento que se tornava mais complexo pela compreensão e reflexão sobre o ato criativo. Nesse estádio de desenvolvimento, o aluno-ator, já com certo domínio prático da criação, do núcleo dramático, passava a expandir sua capacidade para selecionar e eleger acontecimentos e circunstâncias na obra literária, a qual servia como base para a criação.

À medida que a experiência do estudante se tornava mais sólida e ele já possuía algum domínio da ação física com objetos imaginários e das técnicas referentes aos elementos, nos semestres subseqüentes passava a trabalhar com obras mais complexas da literatura clássica russa, sem que fosse abandonado o trabalho do ator sobre si mesmo. Nos dois últimos anos, todo o coletivo tinha que passar pela experiência de uma obra clássica de dramaturgia e de uma adaptação literária de um romance.

Os atores tinham que incluir em seu repertório um espetáculo de variedades, composto de números de circo e outras referências artísticas que exigiam habilidades específicas. Todo ator tinha que possuir pelo menos o domínio de um instrumento musical. Havia também a obrigatoriedade da criação de um "espetáculo”, com enfoque 
no domínio da palavra em verso, contando com a participação ativa dos professores de técnica vocal e da palavra cênica, disciplinas dadas por diferentes professores. No coletivo em que assistimos ao processo de estudos, tivemos a oportunidade de acompanhar o processo do espetáculo com poesias de Puchkin (1799-1837), que tinha como objetivo maior o domínio da ação da palavra em verso.

O coletivo de 22 alunos era formado desde o momento da seleção com critérios artísticos, éticos e disciplinares rigorosos, e isso contribuía para que, nos quatro anos de formação, sob a orientação do principal professor e dos assistentes, se desenvolvesse uma solidez artística e ética nos atores aptos a enfrentarem a profissão. As demais disciplinas, no que tange ao desenvolvimento técnico psicofísico, como voz, palavra cênica, rítmica, dança, luta, esgrima, movimento cênico, estilos, possuíam importância fundamental. Na avaliação dessas disciplinas, eram obrigatórias a escolha e a criação de études a partir de obras que exigissem essas habilidades, como o teatro renascentista espanhol, inglês, francês, etc. Essas técnicas, tanto para o ator quanto para o diretor, eram necessárias para atuarem no variado repertório de obras clássicas, modernas e contemporâneas, mas também eram complementares para o domínio das tão necessárias leis do controle, da precisão, da decisão e adaptação e da expressividade, que garantiriam a qualidade artística.

Penso ser de importância citar as pesquisas de campo que os alunos realizavam como processo do trabalho sobre si mesmo e para as suas criações. Nas férias de verão, o coletivo era designado a trabalhar em Kolkhoznyi (sistema de produção coletiva do campo) e, durante a permanência de dois meses no local de trabalho, em que eram desempenhadas as mais variadas tarefas junto à comunidade, devia transformar essa experiência em campo de observação, transposição artística através da concretização em ações físicas com objetos imaginários.

Esse material recebia um tratamento de estruturação por parte dos alunos, que lhe davam transposição e expressividade artística. O resultado da experiência era apresentado no início do ano letivo em forma de performances, études coletivos e individuais, crônicas, zachins, composições de canções, danças, músicas, etc. Era um espetáculo constituído dos mais variados números, originados a partir dessas observações e experiências vividas pelo coletivo junto a essas comunidades.

Semelhante processo de apropriação física e corporal também era usado quando havia a encenação de textos que remetiam à realidade mais próxima, ou permitiam uma transposição para a atualidade. Esses laboratórios experimentais eram 
vivenciados em locais escolhidos que propiciassem a vivência física e psíquica necessária, exigida para a concepção da encenação de determinado texto. Outra experiência que penso ser importante relatar era um trabalho com animais, resultante da observação, em que o aluno criava études individuais ou com partner. No coletivo dos atores houve uma apresentação da mímesis de cães, pois Leningrado era uma cidade povoada de cães enormes, em que todos os atores se apresentavam com o seu objeto de pesquisa, altamente caracterizados sujeito e objeto, o que se constituiu num espetáculo inesquecível.

No curso de Direção Dramática, da cátedra do professor G. Tovstonógov, as exigências eram gigantescas, pois os futuros diretores, nos primeiros dois anos, eram obrigados a adquirir o conhecimento prático do "sistema”, no que tange a arte do ator: trabalho com ações físicas com objeto imaginário, criação de études individuais, zatchin, crônicas, etc. Era priorizada a especificidade da direção, na apresentação dos trabalhos individuais e coletivos, que, em suma, eram os mesmos já descritos para o ator, sendo que havia a exigência de um olhar diferenciado sobre a invenção cênica, a capacidade mais aguda para dar a idéia de uma expressão artística individual.

Trabalhavam em diferentes materiais, além da experiência individual no resgate de memórias, como poesia, notícias de jornal, fatos da realidade, com os quais deviam encontrar uma forma de resolução artística da idéia contida no material. Para a análise e criação da obra, o método utilizado era o da análise ativa, e o seu domínio constituía a prova de fogo para o aluno continuar no curso. O método estava presente em qualquer criação, desde o material mais simples até o mais complexo, como a análise de romances e textos da dramaturgia clássica.

O aluno de direção cênica, após um ano e meio de curso, iniciava a análise de uma obra completa, que pretendia encenar nessa etapa dos estudos. Esse trabalho de análise da obra, de seus acontecimentos principais, tema, idéia e circunstâncias determinantes era apresentado aos mestres e ao coletivo. Esse material, após ter sido submetido à análise crítica, era aprofundado e muitas vezes totalmente recusado ou reelaborado, até que o aluno apresentasse um projeto de análise coerente com a obra. $\mathrm{O}$ trabalho criativo com o ator, em fragmentos da obra, também era apresentado e passava pelo rigoroso processo de questionamento e análise. Como resultado o estudante-diretor devia apresentar um espetáculo que se constituísse numa unidade artística, com todos os elementos que lhe são inerentes. Na montagem de conclusão do diploma, que era realizado no último ano, o aluno podia voltar ao seu país de origem ou república e 
realizar a montagem em algum teatro local, seguido de defesa do espetáculo. Nesse coletivo dominava uma total atmosfera de criação em cujo ambiente só se respirava arte.

Passo a listar o conteúdo teórico e prático recebido durante minha estada no curso de Pós-Graduação, de 1978 a 1981:

A obra de arte como consciência social; a imagem artística e sua estrutura; princípios específicos da arte teatral; fundamentos éticos da arte teatral; o diretor como organizador do processo da criação cênica; teoria da Direção Teatral; problemas modernos da Direção Teatral; unidade do Processo de Educação e Formação do Ator e Diretor.

Fundamentos da Direção Teatral: Método da análise ativa - fundamento da idéia da regência do espetáculo; “Romance da Vida” como método de aproximação ao pensamento do autor pelo diretor; tema, idéia e problema da obra; conflito da peça e circunstâncias; análise dos acontecimentos da obra; objetivos, superobjetivo e linha transversal de ação da obra e personagens como noção básica fundamental do “sistema” de K. Stanislávski.

> Problemas da Direção Teatral na concretização cênica da idéia: natureza do sentimento do espetáculo; resolução do jogo cênico; atmosfera cênica; tempo e ritmo da ação; resolução musical, cenografia e iluminação do espetáculo; trabalho com os artistas de cenografia, iluminação, música e indumentária.

> Aulas sobre Direção do Drama: trabalho prático como assistente no Curso de Direção Teatral com os estudantes, além do programa estabelecido; trabalho com études com fundamentos na literatura; criação sobre fragmentos de peças dramatúrgicas.

Aulas sobre maestria do ator: fundamentos da maestria do ator; princípios da psicotécnica do ator e suas tarefas; elementos e conformidades da ação cênica; tarefas do ator em relação ao seu treino; acontecimento como unidade fundamental e estrutural do processo da vida; études (exercícios de criação cênica), como forma de domínio integral e natural da ação cênica; caráter de metamorfose do ator no processo de criação;

$>$ Aulas práticas de maestria do ator: trabalhos práticos como assistente no Curso de Atores Dramáticos, com os estudantes, sobre fragmentos de romances e dramaturgia na criação de études; pesquisa sobre psicotécnica do ator; foram 
ministradas por mim aulas de treinamento psicofísico com alunos do referido curso e aulas abertas de treinamento psicofísico.

> Aulas práticas de movimento cênico, estilo, rítmica, esgrima, acrobacia, luta, dança e palavra cênica em horários livres, extracurriculares. Defesa prática e teórica do trabalho: Plasticidade e Expressão do Movimento, pesquisa realizada com os atores do Curso de Teatro Dramático. Participação do elenco da montagem Mandrágora, de Maquiavel (1469-1527), espetáculo final do diretor cubano Armando Crespo, aluno de Sulímov (1913-1994), Leningrado, URSS, 1980.

> Apresentação do trabalho de Direção sobre a encenação do conto de V. Chukchin (1929-1974) Lágrimas de Kuko cumprindo as etapas de estudo e aproximação da obra do autor; análise de direção da encenação; trabalho de criação sobre os fragmentos da obra pelo método da análise ativa para a realização da idéia.

$>$ Assisti a todo o processo de criação, desde o início dos ensaios até a estréia, dos espetáculos Lobos e Ovelhas, de A. N. Ostrovski (1823-1886), e Tragédia Otimista, de V. Vichnevski, direção de G. Tovstonógov, no Bolshoi Teatro Dramático M. Gorki.

$>$ Realizei pesquisas sobre o cinema novo brasileiro, no setor de cinema do LGITMiK, resultando no projeto Ideologia - Visão Artística Fundamental do Cinema Novo Brasileiro, que propunha a inter-relação entre a moderna literatura brasileira e o cinema novo brasileiro. Projeto apresentado para ingresso em doutorado em Moscou, no Instituto de Literatura Mundial Gorki, na especialidade de Literatura Latino-Americana, na cátedra de I. A. Terterian, a qual aceitou ser minha orientadora.

Em dezembro de 1981, fui obrigada a voltar ao Brasil, por não ter conseguido naquele momento uma fonte financiadora para bolsa de estudos de doutorado que me mantivesse na URSS, mas ainda tinha expectativas de um retorno em breve, o que não aconteceu.

O panorama teatral no Brasil, mais especificamente em Porto Alegre, depois de três anos e meio de ausência, se apresentava para mim, em termos profissionais, com poucas perspectivas, sem falar em termos políticos e emocionais, no entanto era preciso começar por alguma parte. O preconceito relacionava-se a fatores diversos: ao país no qual havia adquirido o conhecimento, a minha posição ideológica e, sobretudo, a K. 
Stanislávski, que era visto com suspeita, tachado de psicologismo e ultrapassado. Todos os cursos em voga na época faziam questão de anunciar que não seguiam a tendência psicologizante do sistema stanislaviskiano. A sobrevivência precisava ser garantida e, enquanto não surgia algum trabalho, vendia gelatinas para iluminação trazidas, algumas centenas, da URSS, como também trabalhava temporariamente para a Secretaria de Turismo em pesquisas de opinião púbica.

Por outro lado, dei início no MEC ao processo de reconhecimento do curso feito no exterior, o qual foi se arrastando de universidade em universidade até voltar às minhas mãos depois de mais de dez anos, sem obter nenhum resultado. O curso nunca foi reconhecido e não me trouxe qualquer ascensão na carreira acadêmica, nenhuma pontuação em concursos públicos nem vantagem financeira.

Em março de 1982, um ex-colega convidou-me para dirigir um espetáculo a quatro mãos, com o texto Yerma, de F. Garcia Lorca (1898-1936). Procurei, na medida do possível, dentro do espaço que me era permitido, aplicar os ensinamentos que havia recebido, tanto no que tange ao ator quanto ao diretor.

Na seqüência, passei a trabalhar com amadores ligados a uma entidade de classe, o que me obrigou a exercitar e transmitir na prática os conhecimentos adquiridos. Junto ao grupo eram desenvolvidos os elementos do "sistema”, a capacidade de improvisação e o treino corporal. O grupo tinha como objetivo principal a comunicação direta e imediata através de esquetes, intervenções e performances. Diante dessas características do coletivo e de suas aspirações em relação ao teatro, foi proposta a encenação do texto de Tchekhov O Aniversário do Banco. Essa montagem, totalmente despida de qualquer pretensão cenográfica, se sustentava, sobretudo, na capacidade de improvisação do elenco, era apresentada em comunidades e sofreu inúmeros desdobramentos.

Em 1983, Maria Helena Lopes, diretora teatral conhecida nacionalmente, que havia sido minha professora na universidade, convidou-me a fazer parte do elenco do espetáculo Crônica de uma cidade pequena, inspirada na novela de Gabriel Garcia Marques (1928- ), Crônica de uma morte anunciada. Maria Helena, que considera Eugênio Kusnet e J. Lecoq (1921-1999) seus mestres e trabalha com a improvisação como meio para a criação, me propiciou a oportunidade de poder avaliar e dimensionar o conhecimento adquirido sobre o "sistema” de K. Stanislávski. Apesar de não ter continuado no elenco até a apresentação pública, a participação no processo de criação da referida montagem foi altamente enriquecedora, pois vinha afirmar pontos relevantes 
sobre o jogo cênico e a metamorfose do ator, o que trazia confiança sobre os conhecimentos recebidos.

Fortalecida em minhas convicções e conhecimentos, passai a ministrar um curso de preparação de atores em que era desenvolvido o método das ações físicas de $\mathrm{K}$. Stanislávski, em Estágios I e II, de agosto de 1983 a dezembro de 1984, em Porto Alegre.

Nesse mesmo período, participei como diretora de atores da montagem Antonio Chimango, adaptação do poema homônimo de Ramiro Barcelos (1851-1916), com o grupo que já vinha desenvolvendo os elementos do "sistema”, treinamento psicofísico e improvisação. Também com o mesmo diretor e parte desse grupo, foi realizada a montagem de Macbeth, de Shakespeare, na qual participei como diretora de atores (1998/9).

Assumi a organização de um pequeno grupo de atores, oriundos dos cursos ministrados por mim e procedentes das montagens das quais participei, para a encenação do espetáculo Boca de Luar, (1996/7) inspirado nas crônicas de Carlos Drummond de Andrade (1902-1987), na obra de mesmo nome. Na montagem, atuei como diretora e dramaturga, nesta na qualidade da adaptação da obra literária para a forma teatral.

Ingressei na Universidade Federal de Santa Maria (UFSM) em 1985, na área de Artes Cênicas, na categoria de professor auxiliar, pois, além da graduação, só tinha o reconhecimento de um curso de especialização em Sociedade, Política e Cultura da América Latina, oferecido pela UFRGS (1984). O Curso de Artes Cênicas da UFSM, na época, era o de Educação Artística Licenciatura Plena em Artes Cênicas, extinto em 1994. Nesse curso, ministrei as disciplinas de Encenação, Técnicas de Teatro e Dança, Laboratório de Pesquisa Dramática, Evolução do Teatro e Dança, Prática de Ensino, Metodologia de Ensino em Artes Cênicas.

Em 1992, inicia-se o processo de estruturação e elaboração do Curso de Bacharelado em Artes Cênicas, opção em Direção e Interpretação Teatral, do qual assumi a coordenação. O currículo que entrou em vigor em 1994 foi construído sobre uma base comum para ambas as opções: as disciplinas práticas, como Encenação I a VI, para o ator, e até VIII, para o diretor, Técnicas de Representação I a VI, para o diretor, e até VIII, para o ator, Laboratório I a VIII, para ambos, Expressão Corporal e Vocal I a IV, para ambos, Técnica de Montagem I a IV, para ambos, e as disciplinas teóricas 
sendo iguais para os dois cursos. O método de análise ativa ocupou o lugar de centro unificador do processo de educação e formação do artista como um todo.

Apesar do corpo docente, em seu conjunto, originar-se de diferentes formações, com alguns professores provenientes do próprio curso, os quais haviam sido meus alunos, havia alguns princípios básicos em comum sobre a arte do ator e do diretor que possibilitavam a troca de experiências que enriqueciam a todos. Esse entendimento comum nos levava a realizar projetos que envolviam grande parte das disciplinas práticas e algumas teóricas, em que professores e alunos passavam por uma experiência unitária.

Aqui citarei alguns projetos interdisciplinares, com caráter de ensino, pesquisa e extensão, os quais envolviam grande parte dos professores, em que foi aplicado o método de análise ativa, na análise do material textual e no processo de criação. São eles:

A montagem Mokimpot, de Peter Weiss (1916-1982), na qual atuei como assistente de direção e no processo de análise do texto, cuja pesquisa de linguagem era sobre o clown e o bufão.

> A criação do espetáculo Manantiais, uma saga da cultura gaúcha, tendo como base para a criação contos e lendas de Simões Lopes Neto (1865-1916), Barbosa Lessa (1929-2002) e Auguste de Saint-Hilaire (1779-1853), aglutinava professores e alunos do curso de Artes Cênicas na sua pesquisa, criação e produção. Na preparação do elenco, foram conjugadas e compartilhadas várias experiências e referências dos professores, como a do "sistema" de K. Stanislávski, Meyehrold, Laban (1879-1958), Grotowski (1933-1999), Lecoq, Barba (1936- ), em que o método de análise ativa, através da análise do material textual e a técnica de improvisação, serviu como base no processo de criação. Assumi nessa montagem a assistência de direção e a criação do roteiro, o qual possuía uma estrutura que entrelaçava o real e o fantástico, imagens míticas e históricas, presente e passado. Na seleção do material literário para a criação dos acontecimentos pelos atores e na sua estruturação em espetáculo, foi utilizada a análise da ação, que se constituiu num sólido caminho para a organização do vasto e complexo material produzido pelas improvisações e pesquisa de campo, o qual teve o seu entrelaçamento produzido nos múltiplos níveis da narrativa do espetáculo. 
A montagem de Os Tambores Silenciosos, romance de Josué Guimarães (19211986), em que, além de atuar como assistente de direção, coordenei a equipe de dramaturgia, na adaptação do texto literário para o teatral, que passava pelo processo de seleção de fragmentos e circunstâncias da obra e que se concretizava em acontecimentos através de improvisações, para serem estruturados no roteiro final.

$>$ A Construção de uma Dramaturgia de Imagens a partir dos Poemas de Sam Shepard (1943- ), projeto em que realizei a análise da ação dos poemas, a revelação de seus acontecimentos imersos na palavra poética, as circunstâncias, a idéia, o superobjetivo e a ação transversal. Esses elementos serviam de suporte para a criação, por meio da improvisação, na busca de imagens que revelassem o conteúdo através do poético, em que a palavra só podia surgir como resultado da ação concreta e podia ser usada em sua totalidade, em parte ou estar ausente.

O projeto de pesquisa e criação do espetáculo O Nariz, de Gogol, em que realizei a análise geral da obra e de fragmentos do texto literário, escolhidos pelo aluno, destacando que a análise, sem perder a visão de totalidade da obra, estava na dependência da escolha de cada fragmento, isto é, o desenvolvimento dramático era relativo ao momento do início e do fim da parte selecionada. Essa escolha de fragmentos gerou inúmeras análises e processos de evolução dramática dos acontecimentos. As criações individuais, em que todos os alunos tinham de dirigir um fragmento e também atuar em outros, possibilitaram vasto material criativo que passou por um processo de sistematização e montagem resultando no espetáculo.

$>$ A participação, como co-orientadora, em projetos que aglutinavam algumas disciplinas afins, nos quais se propunha a criação, com base na aquisição de técnicas e estilos específicos do "Bufão", do “Clown” e da “Comédia Dell’Arte”, conteúdos esses transmitidos pela professora doutora Inês Marocco, do departamento de Artes Cênicas, a qual os havia adquirido na Escola Jaques Lecoq, me levou a assumir a função de responsável pela análise ativa do material textual. Atualmente a referida professora está lotada no Departamento de Arte Dramática da UFRGS e atua na disciplina de Direção Teatral, na qual utiliza o método de análise ativa com seus alunos, adquirido através das experiências compartilhadas nos projetos. 
Nas disciplinas de Encenação, o conhecimento do método para a análise do material textual se dava na disciplina de Encenação III, a qual sempre esteve sob minha responsabilidade. Essa ordem do conteúdo, no processo de aquisição do conhecimento prático-teórico do método, se dava por entendermos que o aluno já deveria ter passado pela experiência com as ações físicas com objetos imaginários e a criação do pequeno núcleo dramático através de improvisações. Essas improvisações eram geradas a partir de temas oriundos de material ligado à experiência pessoal do aluno, através do resgate de suas memórias. Esse material, proveniente da própria vivência, levava o aluno a mergulhar em suas raízes e torná-las fonte de criação, na qual dava início ao processo de individualidade artística.

Dentro desse processo evolutivo, já no terceiro semestre de encenação o recurso aplicado para a transmissão do método sempre foi a utilização de material literário, essencialmente contos, por entendermos que esse recurso obriga o aluno a criar a partir de uma estrutura da ação possibilitada pela análise e não a partir do texto dramático, que já vem com o diálogo pronto. Esse procedimento, além de afastar a tendência ilustrativa do texto, força tanto o diretor quanto o ator a entrarem no núcleo da obra e encontrarem soluções individuais criativas na construção dos acontecimentos.

Após ter transmitido os elementos e princípios fundamentais do método de análise ativa através de um texto que eu considerava exemplar, didaticamente falando, cada aluno elegia um conto de sua preferência, devendo justificar sua escolha, suas primeiras impressões sobre o mesmo e suas possibilidades cênicas. Esses aspectos passavam pela verificação da análise da ação por mim junto com o coletivo, podendo então iniciar-se o processo de criação. A disciplina Ética e Estética, também sob minha responsabilidade, que só iniciava nessa etapa dos estudos, também ajudava a estabelecer, através do estudo dos pesquisadores, diretores e diretores-pedagogos, os princípios éticos e estéticos e os métodos que regiam as práticas desses produtores da tradição teatral do século XX. Essas duas disciplinas se complementavam pois levavam a dimensionar a importância da individualidade artística e as tendências de determinada estética, como também possibilitavam obter a idéia de conjunto da criação.

A fonte de experiência prática com o método de análise ativa mais significativa, além da já mencionada, foi como orientadora da dramaturgia e/ou de espetáculos, através da orientação e/ou coordenação de projetos finais de montagem, tanto de alunos de direção quanto de atuação. Foi utilizado o método na criação de espetáculos a partir dos mais diversos textos literários ou de dramaturgia de autores clássicos, modernos e 
contemporâneos. Citarei somente alguns autores para não me alongar demasiadamente em nessa exposição:

Eurípedes - dramaturgia, Sófocles - dramaturgia, Jean Genet - dramaturgia e literatura, Beckett - dramaturgia e literatura, Nelson Rodrigues - dramaturgia, Plínio Marques - dramaturgia, Oscar Wilde - dramaturgia e literatura, Pirandello - dramaturgia e literatura, Ionesco - dramaturgia, Shakespeare - dramaturgia, Cervantes - dramaturgia e literatura, Clarice Lispector - literatura, Hilda Hilst - literatura, Guimarães Rosa literatura, Tchekhov - dramaturgia e literatura, Artaud - dramaturgia e literatura, Gogol literatura, Cortazar - literatura, Jean Jarry - dramaturgia, A. Dumas Filho dramaturgia, Ariano Suassuna - dramaturgia, Edward Albee - dramaturgia, Kafka literatura, Albert Camus - literatura, Arrabal - dramaturgia, Frederico Garcia Lorca dramaturgia, Luis Fernando Veríssimo - literatura, Buechner - dramaturgia, Brecht dramaturgia, Calderon - dramaturgia, Peter Weiss - dramaturgia, Borges - literatura, Caio Fernando Abreu - literatura, Jean Cocteau - dramaturgia, Lya Luft - literatura, Ligya Fagundes Telles - literatura, Cleber Laguna - literatura e dramaturgia .

Atualmente os professores, atores e diretores que concluíram seus estudos universitários no Departamento de Artes Cênicas da UFSM, entre 1987 a 2001, e de que tenho conhecimento, encontram-se atuando em escolas, em grupos de teatro independentes, em secretarias de cultura e também em universidades do país como professores. Todos passaram pelo processo de conhecimento do método em sua trajetória de formação. Uns o assimilaram com maior paixão e domínio do que outros, e a importância que lhe atribuem, em seus trabalhos criativos ou pedagógicos, depende, sobretudo, da individualidade artística e pessoal de cada um, que foge de meu alcance.

Tenho acompanhado a trajetória de alguns atores e diretores que utilizam o "sistema”, mais especificamente o método de análise ativa, em seu trabalho criativo, e o consideram não só um meio para as suas produções artísticas mas também um princípio orientador geral de suas práticas artísticas. Também tenho conhecimento de inúmeros alunos, que concluíram, ingressaram ou estão ingressando em cursos de pósgraduação, em mestrado e doutorado, no país e no exterior, alguns atuando em universidades com conclusão de excelentes dissertações e em processo de finalização de teses de doutoramento. Em muitas dessas dissertações e teses, os objetos de estudo estão ligados diretamente ao “sistema” de K. Stanislávski, enquanto outros, focalizam o ponto de vista dos seus discípulos. 
É por essa formação e experiência aqui explicitadas que me sinto responsável em sistematizar esse conhecimento como uma contribuição para a área teatral. É importante salientar que concretizei o projeto dessa tese em duas esferas, uma teórica e uma prática, sendo que, na segunda, foi realizada a montagem do espetáculo A Dócil, de Dostoiévski. Essa escolha, de realizar uma montagem, como parte do projeto, foi mais um desafio a que me propus, pois, apesar de ter trabalhado com textos de autores russos, sobretudo, Tchekhov, os quais somam mais do que dezenas, entre dramaturgia e literatura, foi a primeira vez que trabalhei com o nada convencional, mas cênico, Dostoiévski.

Entendo que o "sistema” de K. Stanislávski forma uma totalidade que abrange a teoria e a prática da arte do diretor e do ator, tendo esse aspecto pautado a investigação e composição da tese, onde essas duas esferas foram realizadas ao abordar os problemas da "ciência” da arte teatral vinculados à criação artística. A profissão do diretor apresenta dois lados fundamentais, que procurei teorizar nos capítulos I e II, um deles é o de encontrar a chave para dar acesso à idéia da obra através da análise da ação, e o outro é o de conseguir concretizá-la cenicamente pela ação psicofísica do ator.

O capitulo I tratará do método da análise ativa e da sua aplicação pelo diretor na leitura do texto, esclarecendo no que consiste esse método. Nele estão expostos os processos de conhecimento da vida da obra, a criação do romance da vida das personagens. São desenvolvidos os elementos essenciais para a análise da obra pelo diretor, como o superobjetivo, a linha transversal de ação, as circunstâncias dadas. Esses são os elementos que possibilitam revelar a ação do texto, por meio da valorização e da seleção de seus acontecimentos conflituosos gerados pelas circunstâncias dadas. Segue-se a exposição de meu entendimento sobre o método de análise ativa, objeto desse estudo.

O capítulo II se compõe de duas partes, sendo que, na primeira, são expostas as leis da criação cênica, como exigência fundamental do "sistema”, na formação do ator criativo, para a utilização do método. O foco se dá sobre os elementos do "sistema” para a arte do ator considerados essenciais, como concentração, imaginação, o “se” mágico, fé e sentido da verdade, relação, adaptação, liberdade muscular, tempo-ritmo. A segunda parte deste capítulo será acompanhada da tradução, direta do russo, de estenogramas das últimas aulas-ensaios ministradas por K. Stanislávski sobre o novo 
método, no Estúdio de Ópera Dramático, na análise e criação do papel da peça Hamlet, de Shakespeare, juntamente com uma introdução aos mesmos.

Completada a fundamentação teórica e metodológica sobre o recorte que fiz do “sistema”, na apresentação da análise ativa e dos elementos do "sistema” que considero fundamentais para a criação por meio do método, realizei, a segunda parte, que é a prática e se compões do III e IV capítulos e parte final.

O capítulo III é composto da análise literária do texto Krótkaia (A Dócil), de Dostoiévski, em que, primeiramente, foram abordadas as impressões sobre a novela. Nele também focalizaram-se alguns aspectos da imagem artística na novela como: composição, personagens, tempo, espaço, mentalidade dos heróis e arquétipos. Essa investigação auxiliou na compreensão da vida da obra, de sua estrutura, das motivações e origem dos conflitos de suas personagens, como também na concepção da encenação como um todo, na busca das imagens, signos e metáforas concretas que possibilitaram expressar a idéia do espetáculo.

O método de análise ativa foi aplicado, sobretudo, no capítulo IV, por meio da adaptação do texto literário, original, Krotkaia para a encenação do espetáculo A Dócil. A análise se dá sobre o texto adaptado, seguindo a recomendação do método, ou seja, primeiro em seus acontecimentos gerais, seguindo-se a análise da ação detalhada de seus acontecimentos seqüenciais. Na parte conclusiva da tese constam os procedimentos utilizados no processo de criação e as considerações finais sobre as potencialidades do método e do "sistema", como um todo, para a leitura do Material textual e na criação do espetáculo pelo diretor e ator .

Devido à abrangência do "sistema” de K. Stanislávski, elegi os elementos que considero fundamentais para o desenvolvimento da tese, portanto, ao longo do texto, quando me refiro ao "sistema”, trata-se do recorte realizado para esse estudo. 


\section{CAPÍTULO I}

\section{O ESTUDO DOS PRINCÍPIOS DE DIREÇÃO CÊNICA NA LEITURA DO TEXTO A PARTIR DO MÉTODO DE ANÁLISE ATIVA}

O método de análise ativa se apresenta, para mim, como o mais completo meio de trabalho com o ator, nos dias de hoje; ele representa o coroamento de muitos anos de investigação de Stanislávski no domínio da metodologia. ${ }^{9}$

No início do século $\mathrm{XX}$, as inquietações sobre a especificidade artística do teatro, a sua linguagem, expressaram preocupação de todos aqueles que se dedicaram seriamente a essa arte. K. Stanislávski se sobressai entre os artistas, pesquisadores e pedagogos que se dedicaram a encontrar uma espécie de gramática que pudesse dar conta da complexidade da arte teatral e que, através dela, fosse possível expressar a “vida do espírito humano".

As pesquisas desenvolvidas por ele durante toda a sua vida artística, como diretor, ator e pedagogo, as quais originaram o seu "sistema”, culminaram no método das ações físicas. Como decorrência deste, por meio de um processo constante de investigação, preocupado em captar o impulso de vida que originou a criação do autor, K. Stanislávski nos contempla com o método de análise ativa. O método constitui-se num paradigma do diretor teatral para a análise da obra do autor, através da ação, e é um meio para o ator recriar, em seu sentido mais profundo, a atualidade da obra, dando origem ao espetáculo.

A análise ativa consiste em um método capaz de acionar o pensamento ativo e criativo do diretor e do ator, gerando um processo de conhecimento da estrutura da ação dramática, que se complementa e concretiza na prática através do processo de criação do ator, envolvendo todo o seu aparato psicofísico. Esse método de investigação da obra, através da ação do ator e da sua estruturação pelo diretor, experimentado e desenvolvido pelo próprio K. Stanislávski em seus últimos anos de existência, continua a ser utilizado e em processo de desenvolvimento por seus discípulos diretos e indiretos, como também é adotado por artistas do mundo todo que obtiveram conhecimento do mesmo. A eficácia do método e sua flexibilidade têm possibilitado o desvelamento da

\footnotetext{
${ }^{9}$ TOVSTONÓGOV, G. A. Zérkalo Stséni (O espelho da cena). 2 volumes. Leningrado: Iskusstvo, 1980, p.235, v.1.
} 
estrutura da ação em diferentes materiais textuais, respeitando o significado mais profundo do texto, possibilitando, assim, uma criação original a partir da individualidade do diretor e do ator.

A análise ativa se coloca como um meio producente para o diretor conduzir o processo criativo através da ação, princípio primordial do teatro. A investigação da estrutura da ação, que se dá na experimentação através da criação do ator, pode revelar o impulso primeiro que originou a obra, possibilitando, assim, alcançar níveis diferenciados entre texto e ação, que transcendem a mera ilustração da palavra. A maior ou menor complexidade de compreensão da ação dependem da relação dialógica que se estabelece entre texto e sujeito que compreende e desvela a ação contida nele, por meio da vivência.

A investigação da ação do texto pelo método de análise ativa possibilita ao diretor introduzir o ator direta e imediatamente na atividade produtiva com seu corpo e sua mente, colocando-o como parte fundamental do processo criativo.

A importância atribuída ao resgate do sentido primeiro do texto é de importância fundamental para a criação teatral, pois é nele que está contida a verdade que ainda pode nos encantar e revelar algo sobre nossa atualidade, vivenciada no aqui e no agora pelo ator. A arte verdadeira se caracteriza por ser portadora e geradora de vida por conter um "impulso vital” sempre renovado em cada sujeito-leitor-espectador. O teatro tem esse poder de renovação da vida a cada momento da apresentação de um espetáculo. O espectador participa, por identificação, desse fenômeno vital, que é alcançado quando o ator consegue a fusão orgânica do seu ser com a personagem e o poeta.

A meta de K. Stanislávski, durante toda a sua vida, foi compreender e tornar consciente esse "mistério" da criação, pois, para ele, “a verdadeira arte deve ensinar como despertar conscientemente em si mesmo a natureza inconsciente, para a criação orgânica supra-consciente”. ${ }^{10}$

O “sistema”, resultado da investigação e inquietação de toda uma vida, complementa-se com a sistematização do método de análise ativa, que contém em si o método das ações físicas. Este permanece em aberto como meio e possibilita chegar à essência da obra dramática, ao núcleo que determina o sentido da criação, a ação e sua recriação pelo ator. Nesse processo é promovido o desenvolvimento psicofísico

\footnotetext{
${ }^{10}$ STANISLÁVSKI, K. Sobránie sotchinéni v 8 tomakh, 1954-1961. Moiá jizn’ v iskússtve (Minha vida na arte). Tomo 1. Moscou: Iskusstvo, 1954, p.406.
} 
integral do ator, em seu papel, resultando no espetáculo, uma unidade da criação do autor, do diretor e do ator.

Grotowski $^{11}$ (1933-1998) assinala dois princípios nos quais fundamenta seu respeito por K. Stanislávski.

O primeiro foi sua auto-reforma permanente, o seu contínuo submeter à discussão o trabalho, as suas etapas precedentes.[...] $O$ segundo motivo pelo qual respeito Stanislávski é pelo seu esforço em pensar a base daquilo que é prático e concreto. Como tocar o que não é tangivel? Quis encontrar as vias concretas sobre o que é secreto, misterioso. Não os meios, contra os quais lutava e chamava de 'padrões', mas os caminhos. ${ }^{12}$

K. Stanislávski, com o método de análise ativa, concretiza o ideal das buscas artísticas e metodológicas de seu "sistema”, que sempre foi o de possibilitar a formação de um ator que ultrapassasse a mera interpretação de um texto, que participasse ativamente do processo de criação, sendo resgatada a sua individualidade como sujeito criativo, através de sua especificidade artística.

Tovstonógov $^{13}$ fala da evolução constante que sofreu o "sistema", o que testemunha não a contradição muitas vezes apontada, mas a coerência de $\mathrm{K}$. Stanislávski em seu processo de investigação, que se dá na seguinte ordem: o pensamento como fator primordial do processo criativo, com o qual chegou ao subtexto; o monólogo interior, onde o caráter humano se revelava principalmente através do intelecto. Como despertar no ator os sentimentos no processo de existência cênica da personagem? Desde o início, a emoção foi sempre algo derivado; o ator que confia na inspiração e no subconsciente da criação cai no clichê; é preciso confiar na evocação consciente, deliberada das emoções necessárias; o fator volitivo, a “vontade”, produz as emoções necessárias e leva a resultados corretos que correspondem aos conceitos de objetivo e ação total, que ainda hoje mantêm validade.

\footnotetext{
${ }^{11}$ Jerzy Grotowski, polonês, diretor e investigador de teatro. Influenciado pela técnica das ações físicas de Stanislávski, a biomecânica de Meyerhold e o teatro oriental. Dirigiu o teatro-laboratório de Wróclaw, definido como "teatro pobre" e focado na relação ator/espectador. Em 1986 fundou o Centro de Pesquisa e Experimentação Teatral de Pontedera, na Itália, onde em seu último período buscou desenvolver práticas, técnicas e metodologias criativas ligadas ao seu trabalho, chamado "A arte como veículo", no qual investigava os processos ligados aos cantos antigos.

${ }^{12}$ JIMENEZ, S. (org.) El Evanagelio de Stanislávski segun sus apostoles, los apócrifos, la reforma, los falsos profetas y Judas Iscariote. México: Gaceta, 1990, p.492.

${ }^{13}$ TOVSTONÓGOV, G. A. Zérkalo Stséni (O espelho da cena). 2 volumes. Leningrado: Iskusstvo, 1980, p.236, v.1.
} 
Toda essa evolução foi confirmada e comprovada por um processo criativo realizado nos estúdios o qual levou K. Stanislávski a formular as leis da atuação cênica constantes de seu "sistema”. Todas essas "verdades" do "sistema” foram amplamente reconhecidas através da qualidade artística dos atores e dos espetáculos do TAM, nos quais, para a sua criação, na primeira etapa era utilizado o chamado “ensaio de mesa”, em que, por meio de uma cuidadosa análise da idéia, das personagens, dos objetivos e superobjetivo, compreendiam intelectualmente a obra, para só numa segunda etapa passarem para o espaço cênico e atuarem. K. Stanislávski, sempre inquieto em relação aos resultados artísticos de suas investigações, percebeu o papel preponderantemente ativo do diretor nesse processo da criação, enquanto que ao ator era relegada uma posição passiva. Constatado esse perigo, ele percebeu outro, que consistia no desenvolvimento não-integral do psicofísico do ator. Diz Tovstonógov:

A Stanislávski preocupou-lhe muito a falta de uma oportunidade para o desenvolvimento harmonioso, completo, de todo o aparato do ator, o psíquico e o físico, durante o processo de criação, tanto que se pôs a revisar todo o seu sistema e, pouco antes de sua morte, desenvolveu um novo sistema, mais tarde recebendo o nome de método de análise ativa. Stanislávski chegou à conclusão de que somente a reação física do ator, a cadeia de suas ações físicas, a ação física na cena estimulam a razão e a vontade, e evocam, em última instância, tal emoção, o sentimento, graças ao qual existe o teatro. Havia descoberto finalmente o estímulo básico no processo que conduziria o ator 'do consciente ao subconsciente'. ${ }^{14}$

Angel Ruggiero ${ }^{15}$ (1946-1992) também fala sobre as aparentes contradições no desenvolvimento do "sistema”, quando K. Stanislávski inverte o conceito crer para agir e o transforma em agir para crer, o que o leva a mudar os procedimentos dos ensaios.

[...] Com relação à análise de mesa, Stanislávski não se contradisse. Simplesmente, descobriu que o momento de fazê-lo devia ser outro. Não no começo do trabalho do ator, mas no momento adequado, depois que o ator, 'em temperatura', tivesse encontrado o essencial de sua personagem e das situações. É então, que a análise de mesa cobra importância, e serve para que o ator aprofunde sua busca e não se paralise. Aqui, longe de encontrar uma contradição,

\footnotetext{
14 TOVSTONÓGOV, G. A. Zérkalo Stséni (O espelho da cena). 2 volumes. Leningrado: Iskusstvo, 1980, p.237, v.1.

${ }^{15}$ Angel Ruggiero, de origem argentina, exilado na Espanha, se formou com o diretor Raul Serrano em Buenos Aires. Realizou sua vida profissional como professor, ator e diretor em Madri. Vinculado ao teatro independente, foi um dos fundadores do grupo La Quarta Pared.
} 
encontramos uma reafirmação do conceito, porém uma modificação do uso no tempo do mesmo. ${ }^{16}$

Ele conclui que, com essa mudança, K. Stanislávski mostra-nos a lei do desenvolvimento do processo criativo do ator, que é a lei do desenvolvimento do objeto de sua investigação, a personagem. A importância do método enquanto atividade interativa e criativa do diretor e do ator no processo de criação do espetáculo, é confirmada pelos seus discípulos, que aplicaram o método em suas inúmeras criações e no seu processo pedagógico.

\section{ELEMENTOS DO “SISTEMA” PARA A ANÁLISE DO TEXTO}

Antes de entrar nos procedimentos da análise da obra, será definida e esclarecida a terminologia de alguns elementos que a compõem, como superobjetivo, linha transversal de ação e circunstâncias dadas.

\section{Superobjetivo}

K. Stanislávski, em seu "sistema”, avaliou que as forças motrizes da vida psíquica: mente, vontade e sentimento, possuem o poder de mobilizar todas as forças internas da criação, ou seja, ativam todos os elementos da ação, que conduzem para o cerne da obra, para o objetivo essencial do autor, do diretor e do ator. O objetivo principal do diretor e do ator, através do espetáculo, é transmitir todo o material espiritual que o autor reflete na obra, as idéias, os sentimentos, os sonhos, as alegrias e as dores. Esse fim essencial, que levou o autor a escrever a obra, foi chamado de “superobjetivo”, e é ele que movimenta todas as forças psíquicas, elementos, ações e atitudes dos atores em suas personagens.

Consideramos que o superobjetivo é um dos elementos fundamentais do “sistema” para a atitude do diretor diante da análise da obra, para a concretização do espetáculo e para o ator na criação do papel.

G. Tovstonógov considera que:

A idéia mais importante de todas no 'sistema' de Stanislávski é a do 'superobjetivo', tal como ele chamou o sentido principal de uma obra dramática. No trabalho sobre o espetáculo a principal

\footnotetext{
${ }^{16}$ REVISTA MÁSCARA. Stanislávski, Esse Desconocido. Ano 3, número 15. México, D.F.: 1993, p.75.
} 
preocupação de Stanislávski era a de encontrar um verdadeiro e absorvente 'superobjetivo', que subordinasse a totalidade da montagem. ${ }^{17}$

Salienta ainda que K. Stanislávski ampliou o conceito de “superobjetivo” com o de "super-superobjetivo", o qual contempla a totalidade da vida do homem-artista, toda a atividade do autor, diretor e ator e possibilita ligar a individualidade artística com os problemas de importância fundamental na contemporaneidade, fazendo que autores clássicos tenham voz no mundo atual, unindo os pensamentos e os sentimentos dos autores, diretores, atores e do espectador num só impulso.

K. Stanislávski ${ }^{18}$ fala desses vitais propósitos do artista e do ser humano, que podem ser chamados de objetivos supremos e de linhas supremas da ação. Dá um exemplo real de sua vida, que ilustra a origem do super-superobjetivo e da "super-linha transversal de ação” e como surgiu nele essa idéia e necessidade como artista e cidadão: ao ver uma multidão que esperava numa fila durante toda noite, debaixo de neve, para comprar ingressos no dia seguinte, arriscando a saúde e até a própria vida, foi levado pelo desejo de criar um objetivo tão elevado que contemplasse toda a sua vida como artista e homem, que correspondesse ao seu objetivo supremo na vida e ao seu cumprimento, a linha suprema de ação, os quais foram chamados por ele de supersuperobjetivo e super-linha transversal de ação.

O superobjetivo deve conter a idéia do autor, que surge do seu conteúdo mais profundo, pressupondo um mergulho no universo espiritual do escritor, em suas idéias, nos motivos impulsores de sua obra. O superobjetivo do autor é a finalidade principal da obra. Por isso na sua definição deve estar contemplada a universalidade da mesma. O trabalho criativo do diretor e do ator, quer seja a partir de uma obra dramática, quer literária ou de outro material textual, deve orientar-se pelo superobjetivo.

Para Maria Knébel ${ }^{19}$ (1898-1985), a definição do superobjetivo é a principal incumbência dos diretores e atores para concretizar na cena as idéias e sentimentos do dramaturgo, os quais o fizeram escrever a obra. Ele atrai para si todas as tarefas que

\footnotetext{
${ }^{17}$ TOVSTONÓGOV, G. A. Zérkalo Stséni (O espelho da cena). 2 volumes. Leningrado: Iskusstvo, 1980, p.40, v.1.

${ }^{18}$ STANISLÁVSKI, K. Sobránie sotchinénii v 8 tomakh, 1954-1961. Rabota aktiora nad soboi. Rabota nad soboi $v$ tvórtcheskom protsésse perejivânia (O trabalho do ator sobre si mesmo. O trabalho sobre si mesmo no processo da criação da vivência). Tomo 2, Moscou: Iskusstvo, 1954, p.341.

${ }^{19}$ Maria Knébel, aluna de Stanislávski no $2^{\circ}$ Estúdio e atriz do TAM. Em 1936 foi convidada a trabalhar no Estúdio de Ópera Dramática. Pedagoga do GITIS (atual Academia Russa de Arte Teatral GITIS), diretora teatral e autora de inúmeras obras sobre o "sistema" de Stanislávski.
} 
mobilizam as forças internas, como o intelecto, a vontade e o sentimento, e as externas, como as ações, as atitudes e os elementos sensoriais do ator para com o seu personagem. O que possibilita a realização do superobjetivo da obra pelo ator é o seu correto entendimento do papel. ${ }^{20}$

K. Stanislávski, em toda a sua vasta obra, não cansou de reforçar a importância do superobjetivo no trabalho do ator, na criação do papel. Ele afirma que a máxima proposição dos grandes autores dramáticos é oferecer um objetivo emocional para o trabalho do ator que carregue todos os diversos elementos da obra e do papel: “Tudo o que ocorre na obra, todas as tarefas isoladas grandes ou pequenas, todos os pensamentos e ações do artista relacionados com a criação e o papel tendem a concretizar o superobjetivo". ${ }^{21}$

Para ele, a qualidade da obra e o poder de atração do superobjetivo tornam a aspiração real, humana, ativa, como uma artéria que alimenta todo o organismo do artista e da personagem.

K. Stanislávski ${ }^{22}$ declara que o superobjetivo consciente é imprescindível. Aquele que nasce da emoção estimula toda a personalidade do artista, ele é tão necessário como o alimento. E aquele que nasce da vontade é essencial, pois arrasta todo o nosso ser físico e espiritual.

O superobjetivo para o papel deve vir do autor, mas deve ressoar na alma do ator. O superobjetivo gera desejo para a sua realização, estimula a imaginação criativa, absorve nossa atenção, satisfaz o sentido da verdade, desperta a fé e os demais elementos da atitude do ator. Deve ser fundido com a sensibilidade do ator, converter-se em algo próprio, encontrar a essência interior do ator. O superobjetivo deve estar estreitamente unido ao plano do subconsciente.

A busca do superobjetivo exige tempo, atenção e investigação profunda na obra do autor e deve repercutir no espírito do ator. Sobre essa lenta assimilação do superobjetivo por parte do ator, Nemiróvitch-Dântchenko ${ }^{23}$ (1858-1943) diz que:

\footnotetext{
${ }^{20}$ KNÉBEL, M. O. El Último Stanislávski, Análisis Activo de la Obra y el Papel. Madrid: Editorial Fundamentos, 1999, pp.51-53.

${ }^{21}$ STANISLÁVSKI, K. Sobránie sotchinénii v 8 tomakh, 1954-1961. Rabota aktiora nad soboi. Rabota nad soboi $v$ tvórtcheskom protsésse perejivânia (O trabalho do ator sobre si mesmo. O trabalho sobre si mesmo no processo da criação da vivência). Tomo 2, Moscou: Iskusstvo, 1954, p.333.

22 Ibidem, p.334.

23 Vladimir I. Nemiróvitch-Dântchenko, fundador do Teatro de Arte de Moscou, dramaturgo, pesquisador, pedagogo e diretor teatral.
} 
Uma semente ao cair na terra germina, porém ao preço de sua própria decomposição, e exatamente o mesmo ocorre com a obra de um poeta ao penetrar na alma artística, já que desperta sua criatividade, porém ao fazer isso morre dentro dela. ${ }^{24}$

Como já foi dito, a definição do superobjetivo exige um difícil processo de investigação que mobiliza não só o intelecto, mas os sentimentos e a vontade do diretor e do ator, e K. Stanislávski determinou que fosse nomeado por um verbo de ação para reforçar o ímpeto de desejo ardente da criação. A precisão do nome, da ação que este encerra, depende da orientação e do enfoque da obra. A ampliação do superobjetivo, ou seja, a sua universalidade, no plano humano, social e filosófico dá à obra um conteúdo mais profundo.

O superobjetivo universalizado amplia e aprofunda o sentido da obra. K. Stanislávski ${ }^{25}$ dá, entre outros, o exemplo do superobjetivo em Hamlet, que se for determinado assim: "quero honrar a memória de meu pai” tem a conotação de um drama familiar. Mas se for: “quero conhecer o sentido da existência”, resulta numa tragédia mística, na qual o homem que vislumbrou para além da vida já não pode deixar de resolver essa questão. E acrescenta outro mais amplo: “quero salvar a humanidade”, que amplia e aprofunda ainda mais a tragédia.

A eleição das palavras que nomeiam o superobjetivo é de suma importância para a arte e a técnica do ator, e para a orientação do espetáculo como um todo. A escolha errada pode levar o ator à expressão de sentimentos, que o levam à passividade e ao clichê. São numerosos os exemplos extraídos de sua experiência pessoal no papel que o mestre nos dá desse perigo. Aqui citaremos o da obra Mirandolina de Goldoni (17071793), em que o superobjetivo da obra eleito foi: “a dona de nossas vidas é a mulher Mirandolina, a dona da pousada”. Esse só foi formulado, mais corretamente, depois de ter sido corrigido o do papel, no qual K. Stanislávski representava “o misógeno”, pois tinha como superobjetivo: "quero evitar às mulheres". Ao perceber a paralisia da personagem, a falta de humor e ação, compreendeu que o herói amava as mulheres e que sua atitude era fingida e mudou para: “quero galantear em segredo”. Essa mudança

\footnotetext{
24 STANISLÁVSKI, K. Sobránie sotchinéni v 8 tomakh, 1954-1961. Stat'i, réchi, zamétki, dnevniki, vospominânia [1877-1917] (Artigos, Palestras, Anotações, Diário e Recordações [1877-1917]). Tomo 5, Moscou: Iskusstvo, 1958, p.528.

${ }^{25}$ STANISLÁVSKI, K. Sobránie sotchinénii v 8 tomakh, 1954-1961. Rabota aktiora nad soboi. Rabota nad soboi $v$ tvórtcheskom protsésse perejivânia (O trabalho do ator sobre si mesmo. O trabalho sobre si mesmo no processo da criação da vivência). Tomo 2, Moscou: Iskusstvo, 1954, p.336.
} 
tornou o ator ativo, deu vida ao espetáculo e ajudou a estabelecer o superobjetivo da obra de forma mais correta. ${ }^{26}$

O ator, nesse processo de busca, deve ter cautela para não eleger um objetivo secundário, que o desvie do grande propósito do papel. Para isso deve vigiar para que todos os objetivos dos acontecimentos e as linhas da vida da personagem se dirijam a um lugar comum a todos, isto é, ao superobjetivo do espetáculo. Assim, todas as linhas, grandes e pequenas da vida do papel, devem se orientar para um único lugar, o superobjetivo da obra. O superobjetivo e a linha transversal de ação estão intimamente, organicamente, ligados à obra e não podem ser inventados por temas estranhos agregados à mesma.

A renovação da obra, a sua modernização, não pode destruir o eterno nela, que assenta nos grandes temas e idéias que dizem respeito a toda a humanidade. A tendência na obra são os acréscimos modernos, para a sua renovação, que não deve ser alheia à mesma, mas contemplada e descoberta na obra, e permitida pela sua relação com a modernidade.

Portanto a tendência deve se harmonizar com o superobjetivo da obra, não podendo existir autonomamente, por estar vinculada organicamente ao superobjetivo e à linha transversal de ação. Esses dois elementos K. Stanislávski considerou os mais valiosos do "sistema". ${ }^{27}$

O superobjetivo deve orientar o ator ao longo da obra, traçando a linha psicofísica da vida que representa, da ação ininterrupta que atravessa o papel. O propósito da obra, expresso pelo superobjetivo, deve estar sempre presente no espírito do ator, em sua imaginação e sensibilidade. "Do superobjetivo nasceu a obra do escritor, e para ele deve dirigir-se a criação do artista". ${ }^{28} \mathrm{O}$ superobjetivo é o núcleo que une todas as linhas da criação, as quais seguem as forças motrizes da vida psíquica, conectadas a todos os demais elementos do ator.

Knébel, discípula direta de Stanislávski, afirma:

O Superobjetivo tem que ser 'consciente', tem que partir da razão, do pensamento criativo do ator, tem que ser emocional, capaz de

\footnotetext{
${ }^{26}$ STANISLÁVSKI, K. Sobránie sotchinénii v 8 tomakh, 1954-1961. Rabota aktiora nad soboi. Rabota nad soboi $v$ tvórtcheskom protsésse perejivânia (O trabalho do ator sobre si mesmo. O trabalho sobre si mesmo no processo da criação da vivência). Tomo 2, Moscou: Iskusstvo, 1954, p.337.

${ }^{27}$ Ibidem, p.334.

${ }^{28}$ Ibidem, p.338.
} 
excitar toda sua natureza humana, e por fim voluntário, tem que partir de seu 'ser espiritual e físico'. ${ }^{29}$

Quando o superobjetivo é tomado do núcleo da obra, do mais profundo de seus mistérios, desperta a fantasia criativa do ator, estimula sua fé e toda a sua vida psíquica. E, quando bem definido o “o que eu quero”, estabelece todas as relações, ações e comportamento e dá a direção do trabalho prático da criação. É ele que impulsiona o autor a criar sua obra e é ele que vai dirigir o ator em sua atuação, respondendo às perguntas: O que quero? (desejo-objetivo); O que faço? (ação psicofísica); Como faço (habilidade artística); Para atingir “O que eu quero?”. O ator tem de realizar ações lógicas e coerentes que criem uma linha ininterrupta de ações que expressem as idéias e sentimentos da personagem, formando assim a linha transversal de ação e, conseqüentemente, alcançando o superobjetivo. Toda a vida psicológica da personagem e todas as suas ações devem dirigir-se para a realização do superobjetivo. A realização do superobjetivo da obra, que se dá através da linha transversal de ação do ator, é a concretização da idéia fundamental do método pedagógico de K. Stanislávski, partir da criação consciente para atingir o inconsciente.

Com a importância atribuída ao superobjetivo, para a arte do diretor e do ator, K. Stanislávski resgata a força do espírito que a arte deve conter, pois o superobjetivo passa de procedimento a princípio estético, valor espiritual da arte teatral.

\section{Linha transversal de ação}

Todos os elementos da ação interna e externa têm o objetivo de forjar a atitude orgânica do ator em cena e sua preparação para a busca profunda do superobjetivo e da ação central, ou seja, a linha transversal de ação em seu papel. Tudo o que existe no sistema se faz necessário, sobretudo para poder realizar essa complexa tarefa, a linha transversal de ação, atingindo através dela o superobjetivo. K. Stanislávski afirma que não há criação na arte teatral na ausência desses dois essenciais elementos da atuação, simplesmente há a execução de alguns exercícios isolados, que não possuem ligação entre si e que não podem ser considerados arte.

A linha transversal de ação da obra é a concretização da sua linha axial, da sua espinha dorsal, a qual se dá através da ação dos atores. É o caminho por onde o

\footnotetext{
${ }^{29}$ KNÉBEL, M. O. El Último Stanislavski, Análisis Activo de la Obra y el Papel. Madrid: Editorial Fundamentos, 1999, p.53.
} 
superobjetivo se afirma ao longo da obra. Quando ela não existe, a criação não consegue sobreviver, pois a obra se torna mutilada, fragmentada, e não forma uma totalidade. Toda a obra bem construída possui intrinsecamente, por sua própria natureza composicional, o superobjetivo e a linha transversal de ação, e eles são revelados para o ator e o diretor à medida que vão se aprofundando na estrutura da ação e na idéia da obra.

Como já foi esclarecido, o superobjetivo deve conter a idéia central da obra, sendo que K. Stanislávski encontrou uma via concreta para realizar a idéia abstrata, que é a ação psicofísica do ator, a linha transversal de ação, que une organicamente toda a obra. Para cumprir com essa alta missão, criou um "sistema” dos meios de educação do ator, o qual determina que, desde o mais sutil ao mais difícil e complexo movimento psicológico, tudo deve ser transformado em ação.

K. Stanislávski chama linha transversal de ação do ator em seu personagem a tendência ativa das forças motrizes da vida psíquica do ator em seu papel que passam por toda a obra:

[...] para o próprio artista a linha transversal de ação surge como um prolongamento direto das linhas que seguem as forças motrizes de sua vida psíquica, que tem sua origem na mente, na vontade e nos sentimentos. Se não existisse a linha transversal de ação, todas as unidades e os objetivos da obra, as circunstâncias dadas, a relação, a adaptação, os momentos de verdade e de fé ficariam inativos, separados entre eles, não teriam nenhuma possibilidade de reviver. ${ }^{30}$

A linha transversal de ação percorre de um extremo a outro a obra. Não é criada por si só, mas por uma longa série de objetivos menores e outros mais importantes que cumprem o superobjetivo da obra e são absorvidos por este. Ela é considerada um poderoso estímulo para a criação subconsciente da natureza orgânica do ator, e o seu desenvolvimento depende da atração do superobjetivo, que deve ser usado pelo diretor e ator como "uma estrela guia".

O espetáculo, tendo a tarefa fundamental de transmitir todo o material espiritual que está na obra através da ação do ator, necessita de uma linha ininterrupta que ligue todas as ações realizadas pelos atores, que reúna todos os elementos, as diferentes partes e objetivos, num único fecho e os dirija para o objetivo geral.

\footnotetext{
${ }^{30}$ STANISLÁVSKI, K. Sobránie sotchinénii v 8 tomakh, 1954-1961. Rabota aktiora nad soboi. Rabota nad soboi $v$ tvórtcheskom protsésse perejivânia (O trabalho do ator sobre si mesmo. O trabalho sobre si mesmo no processo da criação da vivência). Tomo 2, Moscou: Iskusstvo, 1954, p.338.
} 
Esse fio condutor, pelo qual o superobjetivo da obra vai se afirmando no processo do desenvolvimento do espetáculo, chamado de linha transversal de ação do espetáculo, deve congregar todas as ações, e dirigi-las para o seu fim, o superobjetivo. O superobjetivo é a trilha, o caminho no qual a idéia da obra é afirmada através da ação transversal, linha física e espiritual das personagens realizada pela ação dos atores, a qual reúne todos os fragmentos da obra.

Para o ator, em seu trabalho prático, não basta ter um superobjetivo instigante, é preciso saber concretizá-lo através da linha transversal de ação, para poder chegar ao nível artístico desejado. K. Stanislávski assegura que se o ator:

atua sem a linha transversal de ação significa que não atua na cena dentro das circunstâncias dadas e com o mágico 'se', significa que não incorpora a criação à natureza e ao subconsciente, não cria a 'vida do espírito humano' do papel, como o exige o objetivo principal e o principio de nossa orientação artística. Sem eles não existe 'sistema'. ${ }^{31}$

A linha transversal de ação automaticamente dá origem a sua ação contrária, a linha transversal da contra-ação. Essa oposição, que se dá pela contra-ação, origina novas ações e promove a luta com seus objetivos correspondentes, que precisam ser solucionados pelo ator cenicamente. Essa luta estabelecida entre as duas linhas é o que leva à atividade, sendo essa a base da arte teatral.

No “sistema”, K. Stanislávski ${ }^{32}$ assenta que é a linha transversal de ação contrária que possibilita a geração do conflito entre as personagens movidas por objetivos opostos e é graças a esses choques originados pela ação e reação que a obra possui propriedades cênicas.

\section{Circunstâncias Dadas}

K. Stanislávski fundamenta a análise da obra e a sua criação no preceito de Puchkin: "A sinceridade das paixões, sentimentos verossímeis em circunstâncias supostas: eis o que exige nosso espírito de autor dramático”. ${ }^{33} \mathrm{Na}$ sua prática, ele afirmou a expressão “circunstâncias dadas”, pois elas são propostas na obra pelo autor,

\footnotetext{
${ }^{31}$ STANISLÁVSKI, K. Sobránie sotchinénii v 8 tomakh, 1954-1961. Rabota aktiora nad soboi. Rabota nad soboi $v$ tvórtcheskom protsésse perejivânia (O trabalho do ator sobre si mesmo. O trabalho sobre si mesmo no processo da criação da vivência). Tomo 2, Moscou: Iskusstvo, 1954, p.339.

${ }^{32}$ Ibidem, pp.345-346.

${ }^{33}$ Ibidem, p.61.
} 
enquanto que o diretor e o ator as aceitam como uma máxima para a criação, por isso elas são dadas.

Elas constituem um dos pilares básicos do sistema. K. Stanislávski lhes atribuiu grande valor, pois elas envolvem todo o processo da criação, desde nossa posição e constituição como artistas, a escolha da obra, a sua análise, até as condições da criação e a criação em si. Vejamos o que ele propõe que se entenda por circunstâncias dadas:

A fábula da obra, seus fatos, acontecimentos, a época, o tempo e o lugar da ação, as condições de vida, nosso entendimento da obra como atores e diretores, aquilo que agregamos de nós mesmos, a mise-en-scène, o cenário, os trajes, os objetos, a iluminação, os ruídos, os sons e tudo o mais o que é proposto aos atores prestar atenção durante a sua criação. ${ }^{34}$

O autor, ao criar a obra, propõe as condições em que a mesma se desenvolve: a época, o país, o ambiente, o espaço onde as pessoas vivem, as relações e inter-relações, a disposição de ânimo das pessoas, a mentalidade, as idéias e os sentimentos, que se constituem na soma total das circunstâncias propostas na obra e geram os conflitos na mesma. Desvendar o conflito de uma obra é desvendar as circunstâncias propostas pelo autor.

A capacidade de determinação correta das circunstâncias dadas na análise da obra depende do nível intelectual, cultural e artístico do diretor e também do ator, em todos os aspectos do conhecimento humano e da vida.

Para escolher quais circunstâncias são determinantes na estrutura e composição da obra e quais constituem apenas obstáculos, ou seja, trata-se de circunstâncias secundárias, exige do diretor a capacidade de desmontar não só o mecanismo da obra, o seu esqueleto, mas o seu conteúdo intrínseco. Nesse trabalho é preciso desvendar o que é causa e o que é efeito e quando este se transforma em causa e vice-versa. Elucidar os acontecimentos da obra e encontrar a causa dos mesmos é descobrir as circunstâncias que lhe deram origem; é determinar o seu conflito e, conseqüentemente a ação. As personagens se entrelaçam por objetivos opostos, que levam à luta, ao conflito. Quanto mais profundamente o diretor mergulhar nas circunstâncias da obra e compreender a época em que o autor situa suas personagens, mais ele se aproxima da medula da obra, e, conseqüentemente, do seu gênero.

\footnotetext{
${ }^{34}$ STANISLÁVSKI, K. Sobránie sotchinénii v 8 tomakh, 1954-1961. Rabota aktiora nad soboi. Rabota nad soboi $v$ tvórtcheskom protsésse perejivânia (O trabalho do ator sobre si mesmo. O trabalho sobre si mesmo no processo da criação da vivência). Tomo 2, Moscou: Iskusstvo, 1954, p.62.
} 
Juntamente com o diretor, o ator dá vida àquilo que está entre linhas, àquilo que o autor escreveu, colocando seus próprios pensamentos e estabelecendo sua própria relação com as personagens da obra e as condições em que vivem. $\mathrm{O}$ ator, além de assimilar e incorporar todo o material que recebe do autor e do diretor, acrescenta com sua própria experiência e imaginação novos dados, isto é, novas circunstâncias relativas ao passado, presente e até futuro.

Para o ator, são circunstâncias envolvendo a personagem, toda sua vida detalhada, a situação em que vive e viveu, tudo que constitui o seu mundo interno e externo, seu comportamento, sentimentos, idéias, seus sonhos, tudo aquilo que forma a sua individualidade. Esse material proveniente das circunstâncias propostas na obra, mais os acréscimos do diretor e ainda suas próprias contribuições passam a ser parte espiritual e física do ator, e, como resultado final, ele alcança uma ação real, autêntica e produtiva, intimamente unida à trama da obra.

\section{O TRABALHO DO DIRETOR NO PROCESSO DE CONHECIMENTO DA VIDA DA OBRA}

O trabalho do diretor sobre a obra inicia desde a primeira leitura. Esse primeiro contato com a obra do autor constitui um verdadeiro talismã para a futura criação. Tovstonógov, fiel aos princípios de K. Stanislávski, recomenda uma atitude de isolamento e concentração, nesse momento de conhecimento ou releitura da obra.

[...] em nós transcorrem complexos processos psicológicos e tudo isso se reflete no próprio trabalho criador e em nossa percepção de uma obra de arte, de forma que as circunstâncias em que se lê uma obra assumem particular importância. ${ }^{35}$

Após essa etapa, na fase inicial, recomenda que o diretor evite a chamada “primeira visão”, para torná-la a origem da concepção, pois “ela não só pode ser banal, mas está sujeita ao primeiro impacto representativo e encontra-se no poder da estampa-clichê, porque a primeira visão sempre encontra-se na superfície”. ${ }^{36}$

\footnotetext{
${ }^{35}$ TOVSTONÓGOV, G. A. Zérkalo Stséni (O espelho da cena). 2 volumes. Leningrado: Iskusstvo, 1980., p.180, v.1.

${ }^{36}$ Ibidem, p.144, v.1.
} 
Ele estabelece uma diferença entre primeira visão e a primeira impressão, sendo que esta toca a nossa alma, está ligada ao sentimento, phatos, e a outra, a imagem visual, é nociva para a nossa imaginação. A primeira impressão é valiosa e deve ser guardada e registrada nos apontamentos do diretor, pois, além de ser fonte de estímulo permanente no processo de criação do espetáculo, pode ser conferida durante a montagem. É igualada a um termômetro, e, se essa impressão se confirma no espetáculo, o diretor pode ter um parâmetro do acerto do mesmo.

K. Stanislávski também se referiu à importância da primeira impressão, mas essa foi interpretada por muitos de seus leitores como primeira visão, o que banalizou a primeira impressão e tornou-a prejudicial para a criação de uma obra de valor artístico.

Sulímov ${ }^{37}$ também se refere à importância desse primeiro conhecimento da obra, da inquietação que desperta em nossa alma, o que ele chama de "primeiro sentimento". Esse está ligado aos nossos "pontos dolorosos”, nossos sofrimentos e alegrias, oriundos de nossa experiência de vida, os quais são munição para o nosso superobjetivo, humano e artístico. É nesse transparente e espontâneo sentimento que repousa e afirma-se " $a$ força de nossa viva e ativa posição", de nossos prós ou contras, dos quais surge a individualidade artística. É ele que dá a direção de nossa análise, constitui-se no propósito de nossa entrada no "labirinto da peça" e contém a saída do superobjetivo do futuro espetáculo. ${ }^{38}$

Não podemos esquecer o que K. Stanislávski preconizou para o ator, no primeiro contato com o papel, em seu "sistema”, válido igualmente para o diretor: "Posto que na linguagem do artista conhecer significa sentir é que ele, diante do primeiro contato com a obra e o papel, dá rédea solta não somente à razão, mas também ao sentimento criativo". 39

K. Stanislávski, como diretor e ator, ao longo da sua vasta experiência na investigação do "sistema", sempre dedicou tempo prolongado ao encontro com determinado texto, para penetrar na psicologia das personagens, através da análise de seu conteúdo, determinando o tema, o superobjetivo, a idéia, a linha transversal de ação, as circunstâncias dadas. No novo método, o da análise ativa, esse trabalho de investigação sobre o texto e todos os elementos da análise utilizados antes da sua nova

\footnotetext{
${ }^{37}$ Mar Vladimirovitch Sulímov, professor no LGITMiK, diretor teatral e escritor.

${ }^{38}$ SULÍMOV, M. V. Regissior naediné s piéssoi, 1999 (O diretor em solidão com a peça). Mundo virtual www.domika dramaturga. 03/2002, p. 11.

39 STANISLÁVSKI, K. Sobránie sotchinéni v 8 tomakh, 1954-1961. Rabota aktiora nad róliu (O trabalho do ator sobre o papel). Tomo 4, Moscou: Iskusstvo, 1957, p.69.
} 
metodologia continuam em vigência. Só que, agora, não mais como conceitos abstratos, intelectuais, mas como elementos concretos, precisos, que podem ser plasmados a partir da ação psicofísica do ator.

Os diretores pedagogos e estudiosos que continuam desenvolvendo o "sistema" de K. Stanislávski, na prática e na teoria, recomendam que, antes de estabelecer a concepção, o gênero, o estilo e a estrutura do texto, o diretor deve munir-se de vontade e disciplina, num esforço profundo para entrar no âmago da obra, na vida que lateja nela, nos sonhos, aspirações, desenganos, frustrações, traumas das pessoas que a habitam.

Tovstonógov aconselha a não partir imediatamente para a fase analítica da estrutura da ação, mas desvendar a vida da peça, entrar no universo das personagens, situar-se no mundo delas, perscrutar seus desejos, suas alegrias, tristezas, conflitos, amores, ódios, relações e inter-relações. Esse processo de envolvimento com a vida da obra é concretizado através da chamada criação da "novela da vida" da obra, na qual o diretor completa todas as informações que estão ausentes na mesma, do passado, do presente e até do futuro das personagens.

A concretização desse trabalho exige um esforço imenso do diretor, pois, além do entendimento coerente das personagens com aquilo que o autor fornece na obra, é necessário, para preencher os vazios da mesma, uma grande imaginação. Considerada esta a principal força do diretor, que deve ser coerente com o cerne das personagens e do universo em que elas estão inseridas: o mundo cultural, artístico, econômico, político, histórico, costumes, mentalidade da época, etc. O diretor tem que realizar um grande trabalho de preparação que ultrapasse a primeira visão, adquirindo "um enfoque imaginativo” do texto, próprio de um artista.

O objetivo de toda a arte consiste em recorrer não somente ao intelecto $e$ aos sentimentos, mas à imaginação do espectador também. Despertar a imaginação do espectador e colocá-la a funcionar em uma nova e inesperada direção, que nunca teria surgido espontaneamente. ${ }^{40}$

A imaginação, quanto mais alimentada pela garimpagem no texto, mais fértil se torna, manifestando-se explosivamente. A futura idéia se fortalece e se concretiza cada vez mais, num processo ininterrupto de descoberta de camadas do subtexto, o que abre

${ }^{40}$ TOVSTONÓGOV, G. A. Zérkalo Stséni (O espelho da cena). 2 volumes. Leningrado: Iskusstvo, 1980, p.144, v.1. 
novos campos de visão, em que as relações se multiplicam, expandindo, dessa forma, o universo da obra. A "novela da vida" obriga o diretor a entender os motivos dos atos e das ações das personagens, explicando cada mudança de ação e os ínfimos movimentos da alma. Penetrando através dos fatos, da fábula, que se dão na superfície ou no comportamento das personagens, pode-se decifrar a natureza interna do conflito.

Sulímov também fala dessa aproximação do diretor com a vida da peça, a qual permite, pela compenetração e aprofundamento no texto, que ele viva internamente as preocupações e paixões das personagens, padeça com elas, para poder entendê-las e desvendar os seus segredos. Diz: “A essência da análise é o entrelaçamento de sentimento e reflexão, ligação do raciocínio e observação frios com coração quente...". ${ }^{41}$ As respostas às perguntas, que surgem durante o processo de criação do “romance da vida”, vêm do maior entendimento da vida das personagens.

O texto do autor tem que parecer a continuidade dessa criação do diretor, que resulta do seu envolvimento interno com a obra, participando da existência de seus habitantes, de suas relações uns com os outros. Só depois de compreender ativamente a verdade subjetiva das personagens, da qual nasce a lógica de seu comportamento, suas valorizações e apreciações, e de esclarecer as causas, o solo no qual nascem os conflitos, é que o diretor pode iniciar o desvendamento da estrutura da ação do texto.

É importante o diretor não estar no mesmo nível de conhecimento do texto que o ator no primeiro ensaio coletivo. O diretor deve realizar um estudo detalhado da vida dessa obra, das personagens, para, só depois, determinar os acontecimentos, as circunstâncias dadas, a idéia, o tema, a linha transversal de ação, os objetivos, etc. Sulímov chega a atribuir o insucesso de alguns espetáculos ao fato de o diretor chegar diante dos atores "com uma folha em branco", 42 ou seja, sem ter realizado a prolongada preparação exigida no processo de desvelamento da vida da obra, o estudo aprofundado de suas personagens.

Somente depois de o diretor ter realizado essa importante etapa do estudo do texto, "o romance da vida”, o qual possibilita ao diretor dialogar com o autor, explicando zonas obscuras da obra e, decifrar, nos próprios acontecimentos, a natureza interna dos motivos das personagens, pode passar para a análise da estrutura dessa obra, determinando, assim, os acontecimentos, as circunstâncias e os demais elementos que

\footnotetext{
${ }^{41}$ SULÍMOV, M. V. Regissior naediné s piéssoi, 1999 (O diretor em solidão com a peça). Mundo virtual www.domika dramaturga. 03/2002, pp.10-11.

${ }^{42}$ Ibidem, p.06.
} 
constituem a ação e a composição da mesma. Esse procedimento do diretor, de mergulhar profundamente na vida da obra a fim de captar a sua essência e grandeza, abre a perspectiva para a sua renovação artística e da arte como um todo.

Sulímov $^{43}$ atribui o procedimento leviano e superficial do conhecimento do texto ao mau entendimento do novo método de K. Stanislávski. Em uma carta enviada ao filho Igor C. Alekseivich (1894-1974) em 1935, declara uma nova saída prática para o seu "sistema". Achamos pertinente citar parte da referida correspondência que diz respeito ao método:

Agora eu coloquei em andamento um novo método, uma nova aproximação para o papel. Ele consiste em que, hoje a obra é lida, e amanhã ela já pode ser ensaiada na cena. O que é possível atuar? Muito! A personagem entra, cumprimenta, senta, anuncia algum acontecimento presenciado, manifesta uma série de idéias. Em cada momento o ator age, (igraet-joga), em seu próprio nome, orientandose pela própria experiência. E assim é abrangida a obra toda por episódios, com as ações físicas segmentadas. Quando isso for feito corretamente, sentindo a verdade e provocando a crença com relação ao que está acontecendo em cena - então se pode falar que a linha da vida do corpo humano foi criada. Isso não é pouco, não é ninharia, mas a metade do papel. Pode existir a linha física sem a espiritual? Não. Quer dizer que já está indicando a linha interna da vivência. Eis aproximadamente o sentido das novas investigações. ${ }^{44}$

Esse novo procedimento diz respeito ao trabalho com os atores, e não ao vasto trabalho do diretor, sozinho com a peça. O método de análise da ação, o sentido de sua proposta, exige o domínio, a assimilação da obra pelo diretor, desde o início do trabalho com os atores. O objetivo essencial da cuidadosa análise da obra é o de o diretor poder aprofundar, com base nos fatos superficiais da fábula, a essência do comportamento oculto das personagens, ou seja:

revelar o seu verdadeiro sentido, a abertura do subtexto, os estímulos, impulsos internos, os motivos e os secretos movimentos da alma, os quais determinam subjetivamente a lógica e a verdade do comportamento humano. ${ }^{45}$

\footnotetext{
${ }^{43}$ SULÍMOV, M. V. Regissior naediné s piéssoi, 1999 (O diretor em solidão com a peça). Mundo virtual www.domika dramaturga. 03/2002, p.06.

${ }^{44}$ STANISLÁVSKI, K. Sobránie sotchinéni v 8 tomakh, 1954-1961. Pís'ma 1918-1938 (Cartas 19181938). Tomo 8, Moscou: Iskusstvo, 1961, carta $\mathrm{n}^{\circ}$. 332, p.422.

${ }^{45}$ SULÍMOV, M. V. Regissior naediné s piéssoi, 1999 (O diretor em solidão com a peça). Mundo virtual www.domika dramaturga. 03/2002, p.06.
} 
Polamíchev ${ }^{46}$ (1923- ) entende que o diretor tem de ter consciência do papel fundamental da dramaturgia na determinação da idéia do espetáculo e reforça a opinião de Tovstonógov sobre a importância de o diretor confirmar a “primeira impressão” pelo caminho da análise da obra. Essa primeira impressão em geral “muda no decorrer da análise cuidadosa e minuciosa e dela nasce o entusiasmo e a idéia da obra”. ${ }^{47}$

Ao queimar essa importante etapa com a obra, o diretor reduz o espetáculo na própria montagem, ou na variação do tema da obra, na mera representação da fábula. Diz Tovstonógov: "Uma peça dramática que se constitui uma verdadeira obra de arte representa uma combinação complexa de idéias e ações, a música das palavras, ritmos e cores". ${ }^{48}$

O novo método criado por K. Stanislávski e em desenvolvimento por seus seguidores traz uma contribuição fundamental para a análise da obra, e seus princípios desempenham papel importante para a arte do diretor e do ator. Suas buscas e descobertas se deram essencialmente no sentido de resgatar o que há de vida por trás de um texto e de seus conceitos, revelando, assim, a ação que gera a palavra, para que possa ser vivenciada pelo ator.

K. Stanislávski debruçou-se sobre o problema da interpretação do texto dramático pelo ator, empenhado em chegar ao que dá origem à palavra, àquilo que vem antes dela, o transcorrer da própria vida, que é expressa pela ação, entendida esta como luta que manifesta o conflito. Segundo Tovstonógov, a essência do método, a sua tese principal, consiste em que a ação supõe uma confrontação ininterrupta, pois, diz ele, “não existe vida cênica sem conflito". 49

Polamíchev diz que:

O revolucionário desse método, vivo o máximo, concreto, surge no momento em que o ator, juntamente com o diretor, realiza a análise da ação da peça no espaço cênico, e não pelo longo e demorado caminho do raciocínio, das discussões, sentados à mesa, como era o trabalho anterior, o velho método, o assim chamado 'período de mesa, ${ }^{50}$

\footnotetext{
${ }^{46}$ Aleksandr Mihailovich Polamíchev, professor, escritor e crítico de arte.

47 POLAMÍCHEV, A. M. Masterstvó regissióra: ot análisa $k$ voploschéniu (A profissão do diretor: da análise à concretização cênica). Moscou: Iskusstvo, 1992, p.53.

48 TOVSTONÓGOV, G. Zérkalo Stséni (O espelho da cena). 2 volumes. Leningrado: Iskusstvo, 1980, p.145, v.1.

${ }^{49}$ Ibidem, p.238, v.1.

${ }^{50}$ POLAMÍCHEV, A. M. Masterstvó regissióra: ot análisa $k$ voploschéniu (A profissão do diretor: da análise à concretização cênica). Moscou: Iskusstvo, 1992, p.13.
} 
A análise ativa pode chegar ao âmago da ação do texto. Segundo K. Stanislávski, a própria palavra, quando expressa pelo ator, é ação que deve ser vivenciada pela ação psicofísica e pela visualização de imagens que remetem ao vivido e ao possível de ser vivido ou imaginado. O espetáculo, através da ação do ator, tem que revelar a estrutura interna do texto, o projeto secreto do autor.

Essa nova visão do trabalho com o ator sobre a obra determinou também o procedimento da fase analítica realizada pelo diretor, pois este utilizará uma metodologia concreta, fundamentada nos elementos da ação cênica, descobertos na prática. Os elementos que constituem a ação cênica são os chamados por K. Stanislávski de leis da natureza orgânica do homem em ação e são determinantes, como meios, ferramentas, para a criação do ator e também para o diretor, na análise da obra, no esforço em desvendar o projeto invisível do autor, a composição da obra, a estrutura da ação.

Os elementos da ação cênica constituem uma chave de leitura da obra, como as notas musicais o são para o músico ler a partitura. É uma espécie de gramática do ator e do diretor. O diretor, ao dominar os elementos do "sistema”, possui a capacidade de ler a obra de acordo com os acontecimentos conflituosos. Dentro do "sistema", o acontecimento é determinante, pois ele agrega todos os demais elementos da ação e traz em si o conflito que se estabelece entre as personagens que dele participam.

Knébel, citando esse vasto caminho percorrido por K. Stanislávski, diz:

Stanislávski buscou durante anos a chave e o segredo da análise da obra, e somente os encontrou nos últimos anos de sua vida. Para ele, a investigação da obra e do papel constitui-se em dois lados do mesmo processo. A exploração com a inteligência e a exploração com todo o aparato físico são duas partes inseparáveis de um único processo de conhecimento, ao qual chamamos análise ativa da obra e do papel. ${ }^{51}$

Polamíchev busca os fundamentos do novo método de K. Stanislávski ligados ao problema da dramaturgia nos princípios da teoria do drama de Aristóteles, Hegel, Lessing, os quais focalizam-se unânimes, sobretudo, na ação, e indaga se o método simplesmente se estabelece como um instrumento de ensaio. Para mostrar as principais novas possibilidades que esse método revela para a análise da obra, busca o testemunho

\footnotetext{
${ }^{51}$ KNÉBEL, M. O. Poésia pedagóguiki (Poesia da pedagogia). Moscou: VTO, 1976, p.297.
} 
de Blok $^{52}$, o qual afirma que o novo método "esclarece e explica o aparecimento de muita dramaturgia não explicável com a posição canônica da teoria do drama”. ${ }^{53}$

A vasta teorização e prática de K. Stanislávski são testemunhos do seu esforço constante para encontrar um caminho não repetitivo, no que diz respeito ao mundo artístico, de um autor em relação a outro. A importância do novo método se dá essencialmente por contemplar cada autor em sua especificidade artística. A essência da metodologia do novo tipo de análise estabelecido por K. Stanislávski consiste no processo de valorização dos fatos pela sua qualidade e significado:

'Estudar'- significa na nossa linguagem não somente comprovar a existência, distinguir, indagar e compreender, mas também julgar e valorizar todo o acontecimento de acordo com sua qualidade e seu significado. $^{54}$

Esse trabalho se realiza no plano de nossa imaginação ativa, pois, para conseguir determinar os acontecimentos na obra, faz-se necessário estudar atentamente todas as circunstâncias que os geraram. Estudar todos os motivos que levaram as personagens a agir dessa ou daquela forma exige o conhecimento dos fatos acontecidos, para compreender e julgar quais fatos da obra são para elas importantes ou secundários. Mas valorizar e determinar quais circunstâncias da obra e acontecimentos são determinantes ou episódicos para as personagens exige um julgamento pessoal. Sobre esse caráter subjetivo da valorização dos acontecimentos, Knébel esclarece que:

A análise dos fatos da obra deve surgir como um processo no qual o artista verifica e comprova tudo o que lhe indica o subconsciente e a intuição. É necessário lembrar que, apesar de determinarmos os acontecimentos, os quais existem na obra como dados objetivos, ao selecioná-los, obrigatoriamente incluímos nesse processo um início subjetivo. [...] cada diretor inclui nesse processo aquilo que a ele interessa e lhe é valioso como artista. ${ }^{55}$

Essa subjetividade está na valorização de determinado acontecimento da obra, e é aí que reside a força da individualidade artística, pois já há um olhar diferenciado sobre o fenômeno, um ponto de vista próprio, que é inerente a qualquer criação.

\footnotetext{
${ }^{52}$ V. B. Blok, autor da obra O Sistema de Stanislávski e Problemas Dramatúrgicos, entre outras.

53 POLAMÍCHEV, A. Masterstvó regissióra: ot análisa $k$ voploschéniu (A profissão do diretor: da análise à concretização cênica). Moscou: Iskusstvo, 1992, p. 13, nota 20.

54 STANISLÁVSKI, K. Sobránie sotchinéni v 8 tomakh, 1954-1961. Rabota aktiora nad róliu (O trabalho do ator sobre o papel). Tomo 4, Moscou: Iskusstvo, 1957, p.247.

${ }^{55}$ KNÉBEL, M. O. Poésia pedagóguiki (Poesia da pedagogia). Moscou: VTO, 1976, p.310.
} 
Para Tovstonógov, o ponto de vista do autor em relação a sua obra está intimamente ligado ao gênero, e o que o determina é a eleição das circunstâncias, que sempre são diferentes em cada obra e autor. Trata-se da maneira como este vê a vida, em algumas de suas manifestações, e o motivo que o leva a expressá-la de tal forma. A diferença entre os autores se dá na seleção e organização das circunstâncias. Cada autor contempla o mundo sob determinado reflexo, e é a forma como o autor reflete o seu objeto que o torna único, diferente. O diretor, para poder descobrir a chave, o enfoque do autor, tem que colocar o espelho no ângulo do autor. Os autores podem "tratar do mesmo tema, mas a maneira de refleti-lo é diferente, são diferentes percepções e pensamentos refratados na obra através do prisma do escritor". 56

O diretor, por meio da criação do "romance da vida”, juntou um somatório de conhecimentos e entendimentos ausentes na obra, o que lhe permitiu conhecer e entender as personagens, a origem dos seus conflitos, o que fazem e quais as ligações que possuem com os acontecimentos da obra. Mas, apesar de já ter realizado o vasto trabalho de conhecimento da vida da obra, de suas personagens, e de ter penetrado nas suas verdades subjetivas, a análise da obra, para desvendar o que acontece nela e por que acontece, ainda não foi realizada. Isso se dá com a análise de sua estrutura, com a determinação dos seus acontecimentos.

A análise da obra por meio dos fatos e acontecimentos atinge a essência do método, pois possibilita a concretização da ação, que se dá através da determinação dos acontecimentos seqüenciais. Os acontecimentos são o sustentáculo da ação e através deles, de forma sucessiva, vivenciamos tudo o que acontece na obra. O conhecimento da obra, possibilitado pelo processo de valorização dos fatos, transformados em acontecimentos pelo diretor, constitui a matéria da arte teatral. Citamos Sulímov sobre essa questão:

A interpretação dos fatos e a correspondente transformação deles em acontecimentos de maior ou menor significado, isso já é uma categoria da mobilidade, prerrogativa da direção, ela é 'leitura da direção'. ${ }^{57}$

\footnotetext{
${ }^{56}$ TOVSTONÓGOV, G. A. Zérkalo Stséni (O espelho da cena). 2 volumes. Leningrado: Iskusstvo, 1980, p.174, v.1.

${ }^{57}$ SULÍMOV, M. V. Regissior naediné s piéssoi, 1999 (O diretor em solidão com a peça). Mundo virtual www.domika dramaturga. 03/2002, p.27.
} 
K. Stanislávski aconselha realizar a análise por camadas, sendo que, na mais externa, encontram-se a fábula e os fatos da obra. Os fatos e acontecimentos podem possuir suas próprias linhas, mas há um momento em que as diversas linhas da intriga se unem. As linhas da intriga são planos, camadas, da obra. Ele vincula o conceito de “fato” ao conceito de “episódio”. O fato ou episódio, a partir da valorização do diretor, é transformado em acontecimento cênico, no qual se estabelece a luta das personagens para alcançar seus objetivos. A análise do reconhecimento do fato se dá por meio da seleção das circunstâncias dadas pelo autor, e ela se realiza no segundo plano da obra, onde se situa o conflito. O diretor tem de selecionar as circunstâncias mais importantes que originam os acontecimentos e que entram em choque com os mesmos.

À medida que se analisam os acontecimentos exteriores, eles se chocam com as circunstâncias dadas da obra, que são as que originam os próprios fatos. Analisando-os entendemos as causas internas que estão vinculadas a eles e escavando assim, cada vez mais profundo, nos segredos da vida do espírito humano e do papel, aproximamo-nos do subtexto, chegando à corrente submersa da linha da obra, a qual nos ajuda e leva a entender as causas internas, que provocam, na superfície, ondas de ações, de atitudes e de comportamentos, dos quais, freqüentemente, se originam os fatos. ${ }^{58}$

O mestre entende que, nas obras de Tchekhov, consideradas complexas, a fábula e os fatos não constituem o seu maior significado, pois são as relações que se convertem em núcleo e essência da obra, criando a linha condutora do espetáculo, enquanto os acontecimentos são necessários como suporte para originar o conteúdo interno, expressar o conflito das personagens. Quando o conteúdo e a forma guardam uma relação recíproca, em que há ligação da ação interior com o conflito do acontecimento, com a linha exterior, a fábula, o espírito da personagem se torna inseparável do fato e da fábula. No processo de valorização dos fatos, pela sua análise, torna-se possível compreender as causas interiores vinculadas a eles.

É de conhecimento notório as incursões de K. Stanislávski, tanto como ator quanto como encenador, pelos inúmeros gêneros poéticos, que vão desde os clássicos até o teatro moderno, do naturalismo, realismo, simbolismo até o futurismo. Peter Szondi $^{59}$ (1929-1971), na obra Teoria do drama moderno, aponta as contradições internas entre a forma e o conteúdo existentes nessa dramaturgia, que considera

58 STANISLÁVSKI, K. Sobránie sotchinéni v 8 tomakh, 1954-1961. Rabota aktiora nad róliu (O trabalho do ator sobre o papel). Tomo 4, Moscou: Iskusstvo, 1957, p.247.

${ }^{59}$ Peter Szondi, crítico literário húngaro e professor da Universidade Livre de Berlim. 
problemática em relação ao drama absoluto, o qual está fundamentado na tríade: ação, diálogo e tempo presente. Constata a substituição de seus elementos constitutivos, em que o passado domina o lugar do presente, e o intersubjetivo dá lugar ao intra-subjetivo. Parte bem significativa dessa obra é dedicada à análise de autores que K. Stanislávski também trabalhou, quer como diretor, quer como ator, que são: Ibsen (1828-1906), Maeterlink (1862-1949), Hauptmann (1862-1946) e Tchekhov. Sobre este último o crítico diz que:

Nos dramas de Tchekhov a vida ativa no presente cede à vida onírica na lembrança e na utopia. O fato torna-se acessório, e o diálogo, a forma de expressão intersubjetiva converte-se em receptáculo de reflexões monológicas. ${ }^{60}$

Anatol Rosenfeld (1912-1973) na obra O teatro épico analisando os mesmos autores referidos acima destaca os elementos épicos que estão presentes desde a tragédia grega e indica as transformações que sofreram ao longo do processo histórico. Sobre as obras de Tchekhov assim se refere:

[...] o diálogo passa a ter função sobretudo expressiva, ou seja lírica (o que representa na estrutura dramática função retardante, épica). Debaixo da troca superficial de comunicações revelam-se estados emocionais, aquela 'corrente submarina' de que fala Stanislávski. $O$ diálogo é eivado de entrelinhas expressivas e passa a compor-se em larga medida de monólogos paralelos, cada personagem falando de si sem dirigir-se propriamente ao outro. É uma espécie de cantarolar que suspende a situação dialógica. ${ }^{61}$

Apesar dos fatos nessas obras se apresentarem de forma tênue, K. Stanislávski fundamenta sua análise no acontecimento como base da ação, sendo que o processo de valorização dos fatos, no curso de seu desenvolvimento na obra, é inseparável da sua justificação, pois exige por parte do diretor a descoberta do motor que está escondido por baixo das relações das personagens. Ele recomenda que, no processo de valorização dos fatos e sua justificação, para a composição da obra e, sobretudo, para as personagens que deles participam, se use o procedimento de "remoção" ou "suspensão mental” do fato que está sendo julgado e, então, se procure compreender o que

\footnotetext{
${ }^{60}$ SZONDI, P. Teoria do Drama Moderno [1880-1950], São Paulo: Cosac\&Naify, 2003, p.91.

${ }^{61}$ ROSENFELD, A. O Teatro Épico. São Paulo: Perspectiva,1994, p.92.
} 
aconteceria com as personagens envolvidas no acontecimento, sem a sua existência, e como isso teria influencia "sobre a vida do espírito humano". ${ }^{62}$

Esse recurso também ajuda a clarificar se trata-se realmente de um acontecimento ou é apenas um obstáculo ou circunstância. É necessário construir as mais diversas questões, coerentes com o caráter dos protagonistas e com a história do autor, para verificar quais dos fatos operam mudança significativa no destino das personagens e qual deles determina que essa história seja contada pelo autor. "Isso nos obriga a uma comparação do passado com o futuro da obra, de tal forma que podemos ver a obra em movimento e adivinhar o seu desenvolvimento”, declara Knébel ${ }^{63}$.

A criação do "romance da vida” possibilita a visão da totalidade das personagens que compõem a obra, e isso certamente ajudará a realizar essas comparações de tempo necessárias para saber avaliar o grau de significação dos acontecimentos para as personagens.

O meio de determinar a importância do acontecimento na obra de acordo com a sua "remoção" foi também aconselhado por Aristóteles na Poética, quando se refere à necessidade do acontecimento para a unidade da obra. Aqui, K. Stanislávski não tem em vista a ação linear aristotélica, mas a coerência da linha de ação interna, no projeto do espetáculo e do papel, conforme a concepção do autor, dependendo de suas escolhas estéticas.

O acontecimento precisa ser imprescindível para a existência das personagens e, conseqüentemente, para a história. O conhecimento da estrutura da obra se dá por meio da valorização dos acontecimentos por necessidade, visando a coerência interna da obra em relação às personagens que dela participam. $\mathrm{O}$ fato deve ser fundamentado, ter sua base "na vida do espírito", incluindo-se na linha interior, no subtexto da personagem. Ele tem de ser necessário para o papel, a fim de que a vivência siga uma linha lógica e conseqüente. É um procedimento que exige um trabalho enorme e complexo, realizado com a razão, auxiliada pelos sentimentos e pela vontade criadora.

Trata-se de um trabalho concreto, ativo, da imaginação, que o diretor tem de efetuar a partir das indicações da obra. Desse julgamento, sob o ponto de vista humano e pessoal, de “forma autenticamente real”, o fato é transformado em acontecimento, com base na individualidade artística, na concepção da vida, na cultura, na experiência e

\footnotetext{
62 STANISLÁVSKI, K. Sobránie sotchinéni v 8 tomakh, 1954-1961. Rabota aktiora nad róliu (O trabalho do ator sobre o papel). Tomo 4, Moscou: Iskusstvo, 1957, p.247.

${ }^{63}$ KNÉBEL, M. O. Poésia pedagóguiki (Poesia da pedagogia). Moscou: VTO, 1976, p.319.
} 
nos sentimentos do diretor. K. Stanislávski assim define a individualidade artística: “ $A$ individualidade cênica é antes de tudo a individualidade espiritual. É aquele ângulo de vista do artista em relação à criação, é aquele prisma artístico, através do qual ele vê o mundo, as pessoas e a arte". ${ }^{64}$

Sulímov cita três fundamentos obrigatórios que constituem o caminho da análise:

Nós sempre temos que colocar perguntas: o que aconteceu, o que mudou em relação àquilo que era. Esse é o primeiro fundamento. Ele existe por essência determinando os acontecimentos seqüenciais. [...] Segundo: nós devemos esforçar-nos para entender não somente aquilo que está em ligação com os acontecimentos das personagens [...], mas necessariamente procurar responder à pergunta 'o que elas fazem', isto é, abrir caminho para seus comportamentos, para o entendimento de suas ações. E terceiro: esclarecimento da natureza do conflito, 'drama é luta'. B.L. Belinski determinou isso com total precisão: 'O drama se dá quando uns pisam nos outros para alcançarem o topo'. A luta determina o conflito-oposição de idéias, posições, objetivos, caracteres das personagens vigentes. ${ }^{65}$

Ao desvendar o fluxo da própria vida, o movimento dos acontecimentos da obra, o diretor está se aproximando da compreensão do superobjetivo, carregado pela linha transversal de ação ao longo do espetáculo. É necessário encontrar o caminho para o comportamento e para o entendimento das ações das personagens e entender o que elas fazem e por que fazem. A representação viva da existência humana, com base nas ações das personagens, na sua psicologia, e nos seus sentimentos, é a essência do teatro.

Revelar a verdade da obra através da ação na qual assenta o drama, do comportamento e atos das personagens é uma tarefa que só pode ser concretizada se o diretor for capaz de analisar todo o material da obra e reunir todas as informações dos sentimentos e conhecimento em um único sistema - o do espetáculo.

O sistema do espetáculo consiste no nascimento interligado e interordenado necessariamente com cada palavra para o conhecimento do objetivo artístico, expressando o superobjetivo do espetáculo. $O$ sistema do espetáculo é a síntese da obra, que compreende o

\footnotetext{
${ }^{64}$ STANISLÁVSKI, K. Sobránie sotchinéni v 8 tomakh, 1954-1961. Stat'i, réchi, zamétki, dnevniki, vospominânia [1877-1917] (Artigos, Palestras, Anotações, Diário e Recordações [1877-1917]). Tomo 5, Moscou: Iskusstvo, 1958, p.422.

${ }^{65}$ SULÍMOV, M. V. Regissior naediné s piéssoi, 1999 (O diretor em solidão com a peça). Mundo virtual www.domika dramaturga. 03/2002, p.16.
} 
superobjetivo e o sistema de encarnação artística do autor e a composição do espetáculo do diretor. ${ }^{66}$

O sistema do espetáculo é o compromisso do diretor com o autor e com o conteúdo da obra. Para captar o conteúdo espiritual da obra, faz-se necessário determinar o seu núcleo, compreender o que aconteceu e o que mudou na vida das personagens e o que está em ligação com os acontecimentos das mesmas. K. Stanislávski afirma que:

O mais importante é que o artista seja capaz de captar os centros básicos da obra, os seus pontos nervosos, os quais a alimentam e a movem, transmitindo-lhe o tom que possui. O artista, reconhecendoos terá de imediato, em suas mãos, a chave que lhe permitirá compreender a criação do poeta. ${ }^{67}$

A tarefa do diretor, como ideólogo do espetáculo, de saber em nome de que está montando a obra, o que se propõe descobrir nela e quais os seus objetivos com a mesma o leva a atribuir a responsabilidade pessoal do papel ao ator, e torná-lo maximamente ativo, para que possa descobrir o mundo interno da personagem, o seu superobjetivo.

A realização do superobjetivo da obra obrigatoriamente tem que passar pela visão artística do diretor e do ator, na qual a subjetividade de ambos desempenha um papel significativo, que leva a uma compreensão pessoal e única da idéia da obra. Há uma ligação intrínseca entre o primeiro sentimento, a idéia e o superobjetivo.

K. Stanislávski, como homem de teatro, viveu e lutou incessantemente para poder estabelecer princípios e meios para um teatro espiritual, os quais pudessem garantir a possibilidade de expressar em cena “a vida do espírito humano”, “a expressão da alma humana”. O superobjetivo do espetáculo é o elemento que viabiliza o cumprimento dessa missão cultural e tem a função de influenciar o mundo espiritual do espectador, devendo levar a uma mudança em sua alma e, como conseqüência, no clima moral da sociedade. Seus estudos transcendem as leis que ditam procedimentos do fazer artístico, mas os seus princípios artísticos, obrigatoriamente, trilham caminhos subjetivos, que são universais.

\footnotetext{
${ }^{66}$ SULÍMOV, M. V. Regissior naediné s piéssoi, 1999 (O diretor em solidão com a peça). Mundo virtual www.domika dramaturga. 03/2002, pp.01-05

${ }^{67}$ STANISLÁVSKI, K. Sobránie sotchinéni v 8 tomakh, 1954-1961. Stat'i, réchi, zamétki, dnevniki, vospominânia [1877-1917] (Artigos, Palestras, Anotações, Diário e Recordações [1877-1917]). Tomo 5, Moscou: Iskusstvo, 1958, p.462.
} 
É fundamental o conhecimento da estrutura dramatúrgica da obra, pois isso possibilita ao diretor antever e intuir o superobjetivo e a ação transversal. A análise "racional” da obra fornece conhecimento profundo do texto, por meio da penetração na vida e nos acontecimentos da obra que levam à compreensão e apreensão de toda sua amplitude, da idéia principal que a sustenta, o superobjetivo. Apreender a totalidade do superobjetivo da obra significa apreender a concepção do autor. Ele contém a idéia e o tema da obra que são estabelecidos pelo diretor preliminarmente ao trabalho de experimentação com o ator.

A idéia da obra é aquilo que o autor quer expressar com ela, seus conceitos, sua visão de mundo, sua posição. O tema é sobre o que a obra fala, através dos fatos fundamentais da trama, e está ligado à fábula, à seqüência objetiva dos fatos. Entendemos que, para determinar o tema em sua complexidade, é necessário ligá-lo ao enredo, ao argumento, chamado siujet em russo, entendido como o conjunto de ações e de acontecimentos que se desenvolvem concretamente na obra.

O enredo contém a explicação e a valorização dos fatos pelo autor. É mais complexo e rico que a fábula, pois, além de ser mais detalhado, há a inter-relação das personagens com o fato e com a idéia do autor, o que lhe confere um caráter subjetivo, dado pela valorização dos fatos. O significado do tema muitas vezes está ligado ao nome da obra. De acordo com Kokórin ${ }^{68}$ (1932-), para poder determinar tanto o tema quanto a idéia é necessário

revelar as inter-relações das personagens, seus atos, caráter, esclarecer o que elas querem, o que ambicionam, a sua perspectiva, para onde vão, aonde querem chegar, por que e com quem se conflituam. ${ }^{69}$

\section{ANÁLISE ATIVA DA ESTRUTURA DA OBRA}

O modelo de análise aqui explicitado será conforme foi adquirido, assimilado, e como foi aplicado no trabalho prático. Na etapa da análise da estrutura da obra, com todos os elementos que a constituem, é aconselhável que o diretor parta primeiramente

\footnotetext{
${ }^{68}$ Anatolii Konstantinovitch Kokórin, diretor teatral, pedagogo e escritor.

${ }^{69}$ KOKÓRIN, A. K. Vam priviet ot Stanislávskovo (Saudações de Stanislávski para vocês). Moscou: A. K. Kokórin, 2001, p.42.
} 
para a descoberta dos seus acontecimentos principais, a fim de que possa ter a totalidade da mesma, partindo do geral para o particular e para o singular. Esse procedimento é recomendado por K. Stanislávski, de não esmiuçar os acontecimentos no início da análise, mas de perceber a obra em sua totalidade através dos principais acontecimentos.

O chamado universo da obra, o seu plano geral, universal, engloba toda a obra e é também chamado de grande círculo. Este constitui o universo no qual a história vai ser contada. Nesse grande círculo, nós detectamos e evidenciamos, em primeiro plano, o acontecimento inicial e o acontecimento final, para se estabelecerem como marcos, por sua “estabilidade". Tudo o que ocorrer entre esses dois acontecimentos é aquilo que poderíamos chamar de história, onde o tema se desenvolve. O universo em que a história está inserida, marcado desde o seu início, pode ser constituído de um ou mais acontecimentos, dependendo de cada autor, da especificidade artística da obra em questão e de seu projeto composicional.

Saber determinar o universo da obra, o solo no qual ela vai germinar e se desenvolver, é de importância fundamental, pois é nele que as personagens tecem a sua vida. Do entendimento multifacetado desse universo, em seus aspectos sociais, econômicos, políticos, culturais, existenciais, depende, em grande parte, a complexidade da história. Esse universo deve ser concretizado cenicamente, no espetáculo, através da construção dos acontecimentos ou acontecimento inicial. Ele é o trilho onde a vida da obra passa a transcorrer, no qual as personagens lutam, desejam, odeiam, amam, etc.

Dentro do método, a determinação do acontecimento inicial e do final ajuda na percepção da totalidade e dá orientação à análise. São quatro os acontecimentos considerados essenciais no universo da obra e que devem ser identificados para que se possa ter uma visão geral da mesma: o acontecimento inicial, que nos situa no contexto onde vai eclodir o problema, em que inicia a principal circunstância dada; o acontecimento fundamental, determinado pela principal circunstância dada que deslancha a história; o tema, em que inicia a linha transversal da ação, que carrega e une em um único fio todas as ações dos acontecimentos seqüenciais que compõem a história; o acontecimento central, que deve constituir o ápice do conflito, o clímax, o fim da linha transversal da ação; o acontecimento final, também chamado de principal, pois ele abrange a solução ou não do conflito. Nele deve desembocar a idéia graças à qual o autor escreveu a obra, consciente ou inconscientemente, junto com o superobjetivo do diretor. 
Do acontecimento inicial emerge a principal circunstância dada, e através dela acontece a transgressão da ordem e a quebra da "estabilidade" do mundo existente, gerando o acontecimento fundamental, onde a história, também chamada fábula, passa a transcorrer e dá início à linha transversal de ação. Por meio dos acontecimentos seqüenciais, o movimento da linha da ação transversal prolonga-se até o fim do acontecimento central, para onde todas as forças convergem, determinando o clímax da história. Só depois de detectar-se a idéia geral da obra, no que tange à sua estrutura básica, pode-se dar prosseguimento ao trabalho analítico de cada acontecimento singular. Entre os acontecimentos inicial e final, devem ser desvendados todos os acontecimentos seqüenciais, que constituem a história propriamente dita, o enredo, juntamente com as circunstâncias que lhes dão origem e todos os elementos da ação que fazem parte de cada acontecimento singular.

Ao determinar a estrutura básica da obra, o diretor já tem condições de vislumbrar o tema e a idéia da obra, mas é aconselhável não os formular ainda. A análise detalhada de cada acontecimento exige do diretor a seleção exata da circunstância única que o determina, a qual dá origem ao acontecimento e, conseqüentemente, gera o conflito entre todas as personagens que dele participam.

Em cada acontecimento, além de ser determinada a circunstância que lhe deu origem, deve ser desvendado o objetivo do mesmo para a história, no projeto de composição do autor, as personagens que participam dele, seus objetivos e obstáculos. A circunstância e o acontecimento devem abarcar todas as personagens que estão envolvidas no conflito naquele determinado momento.

O universo inicial, como já foi observado, é composto por acontecimentos que expõem a ordem vigente, social, econômica, filosófica, cultural, existencial, em que as personagens estão inseridas. Ele é o somatório de todas as circunstâncias que o determinam, mas o nomeamos pela circunstância mais significativa que o caracteriza, ou seja, a mais ampla, que subordina todas as demais. Cada autor, na criação de sua obra, dispõe do número de fatos que julga serem necessários para expor esse universo onde as personagens estão situadas, antes de iniciar o verdadeiro problema que enseja a história. O universo inicial dado pelo autor, com sua complexidade, é expresso pelas ações das personagens envolvidas nesses acontecimentos.

Se tomarmos o exemplo de Romeu e Julieta, Shakespeare nos fornece uma exposição bastante ampla, antes de iniciar a história, ou seja, antes dos protagonistas se conhecerem e se apaixonarem. São, no mínimo, cinco os acontecimentos que fazem 
parte desse universo expositivo, os quais nos situam no mundo das personagens, sob os seus aspectos sociais, econômicos, políticos, pessoais, etc.

O primeiro acontecimento desse universo “estável” inicia com a briga das gangues adversárias, representantes das famílias rivais, Montecchio e Capuleto, na praça pública. Instantaneamente, percebe-se a existência de um mundo em desavença, o que culmina com o aparecimento da autoridade, que promete punir os responsáveis pela desordem. Nesse encontro detecta-se, além do sistema vigente, representado pela autoridade do príncipe, o domínio da cidade pelas duas famílias rivais. Essas, apesar de suas reputações terem sido abaladas pelo escândalo, têm suas atenções, naquele momento, voltadas para os filhos.

Em seguida, ocorre um acontecimento cujo foco é Romeu, único rebento da família Montecchio totalmente alheio aos interesses e desavenças entre as duas famílias. Nesse acontecimento, é desvendado o caráter romântico de Romeu. A seguir, nos é apresentado o mundo de Julieta, também filha única, inocente, ingênua, submissa à vontade dos pais, sem ter a mínima idéia do que seja o amor.

Na seqüência, ocorre outro acontecimento: o pai de Julieta, num ato demonstrativo de não-abalo social, organiza uma festa e aproveita para comprometer sua inocente e ingênua filha com o abastado pretendente Páris. Dentro de todo esse quadro, aparecem outros aspectos reveladores do caráter elevado de Romeu, típico do papel de herói. Junto com seus amigos, numa atitude audaciosa, característica da juventude, penetra mascarado na festa do inimigo.

Shakespeare nos apresenta esse universo expositivo caracterizando não somente o contexto social, político e econômico, mas revelando sua simpatia para com os heróis da futura história, o que cria no receptor empatia pelos mesmos. Esse quadro denso transcorre antes de iniciar o problema, ou seja, o real conflito da peça, o surgimento do tema do amor, que se dá no interior do acontecimento "Festa”.

Chama-se a atenção para o ponto de que o primeiro acontecimento desse universo, o confronto na praça, é potencializado no acontecimento "Festa" pela desconfiança de invasão e presença dos supostos inimigos. Aqui, no interior do acontecimento "Festa”, o problema eclode, com o surgimento da principal circunstância dada, a atração amorosa entre Romeu e Julieta.

Nesse momento, o acontecimento "Festa" passa a ser pano de fundo de um outro acontecimento que se estabelece em primeiro plano, denominado por nós acontecimento fundamental, conseqüência da principal circunstância dada, no qual se 
realiza a magia hipnótica entre o jovem casal, causada pela força do surgimento do amor. A esse acontecimento fundamental, conseqüência do aparecimento da principal circunstância dada, nós chamaríamos de "Encantamento Amoroso". Ele entra em confronto com o mundo dado, em que domina a guerra entre as duas poderosas famílias, determinando que, a partir desse momento, se desenvolva toda a luta dos protagonistas para concretizar o seu amor dentro desse solo hostil.

Para termos certeza do ponto em que começa a história, aplicamos o procedimento de "suspensão” do acontecimento, recomendado por K. Stanislávski a fim de saber se ele é determinante para o nascimento da história, se ele envolve todas as personagens e se o que vai transcorrer se estabelece como antagônico ao mundo existente, como contra-ação da linha transversal de ação que está nascendo.

A valorização dos acontecimentos que fazem parte do universo inicial da obra depende da concepção do diretor, mas esse núcleo traz um forte contraste com o que irá suceder na história, pois ele se estabelece como contra-ação da linha transversal de ação, que se põe em marcha no momento em que entra a principal circunstância dada, em que inicia a história, o tema. O conflito principal, que vai percorrer toda a história, origina-se das forças antagônicas que se estabelecem desde o momento em que surge a principal circunstância dada, a qual se opõe ao mundo existente. A luta detonada pela principal circunstância dada só tem seu término quando todas as forças antagônicas se conjugam e se resolvem, o que acontece através do processo interno do acontecimento central até a sua finalização.

No caso de Romeu e Julieta, essa luta cessa com a morte dos dois amantes. A circunstância que dá origem a esse acontecimento é o não-recebimento da carta do padre Lourenço, na qual Romeu é advertido da falsa morte de Julieta.

Ele acredita que Julieta morreu e, chegando ao jazigo da família antes de Julieta acordar, decide morrer junto com ela, pois a vida não tem mais sentido para ele, sem o amor. Julieta, ao acordar, vendo Romeu morto, também se mata.

Os dois provam um ao outro o seu amor incondicional desafiando as leis dominantes, das quais os pais são representantes, com a renuncia à própria vida. Concretizam o seu amor no plano transcendente, já que nessa existência isso lhes foi negado pela mentalidade obscura das intrigas familiares. A tragédia é a história da morte em nome do amor.

A partir desse final trágico há a volta ao mundo inicial, ou seja, ao universo que se estabeleceu como contra-ação, só que transformado pela tragédia, com nova ordem, 
representada pelo acontecimento final, também chamado de principal, em que as famílias se reconciliam. A paz é conquistada como resultado da luta pela realização do amor dos dois jovens. Esse final leva à universalização da idéia do amor, pois é através da sua força que a paz foi alcançada, e também mostra os altos sacrifícios de duas vidas em pleno desenvolvimento, inocentes, puras e plenas de ideais, sendo destruídas pela intolerância e vontade de domínio daqueles que as geraram.

Percebe-se que, diante da tragédia, as famílias, tomadas pela dor da perda de seus únicos herdeiros, tomam consciência da sua própria destruição. Surge a dúvida se trata-se de uma trégua entre os inimigos ou se realmente houve um reconhecimento verdadeiro na paz decretada. No filme de Franco Zefirelli (1923-) o final deixa em dúvida essa possibilidade de paz duradoura, o que é captado pelos olhares entre os dois progenitores. Nesse final se concretiza a concepção de mundo do diretor e o que ele quis dizer com o espetáculo ou filme.

No exemplo dado, Romeu e Julieta lutam pela concretização do seu amor apesar de todos os obstáculos, sob as mais adversas circunstâncias impostas. Tudo o que fazem é para realizar esse superobjetivo, que é carregado pela linha transversal de ação, a qual se impõe através das ações conflituosas realizadas em cada acontecimento. A história contada tem como fundo o universo inicial, que está presente no desenrolar da mesma e se constitui o maior motivo dos choques e obstáculos existentes.

O tema em desenvolvimento tem em oposição o universo inicial, que se estabeleceu como contra-ação, e entra em conflito constantemente com os objetivos e a linha transversal de ação dos protagonistas. A presença do contexto, no transcorrer da história, como pano de fundo da luta, é a causa para que haja essa luta, que se evidencia, em primeiro plano, sobretudo, nos acontecimentos iniciais e no acontecimento final, transformado esse ou não. Neste acontecimento final, também chamado por nós de principal, o sentido da história é revelado. Nele o autor coloca a sua idéia, e o diretor concretiza o que ele quis dizer ao longo do processo do espetáculo.

O universo inicial estabelecido pode ser representado por uma única personagem, ou por um grupo que entra em choque com outro, quebrando-se essa estabilidade e dando origem à história. Para determinar a principal circunstância que ocorre no universo inicial, a qual dará origem ao acontecimento fundamental, que inicia o conflito da obra, é necessário fazer perguntas sobre sua importância e do acontecimento por ela gerado na vida das personagens envolvidas. Se, sem o acontecimento, a história igualmente se desenrolaria, ele não pode ser considerado o 
acontecimento gerado pela principal circunstância dada. Aqui, se trata da aplicação do princípio de “suspensão" do acontecimento, recomendo por K. Stanislávski, e dos fundamentos citados por Sulímov.

Em grande parte das obras, o título está relacionado ao desenvolvimento do tema, ligado à fábula que inicia com o estabelecimento da principal circunstância dada. As circunstâncias são fatos que aconteceram ou acontecem e que podem ser convertidos em acontecimentos e vice-versa. Nem toda circunstância que aparece no interior do acontecimento dá origem a outro acontecimento, podendo ser considerado um obstáculo, pois esse não muda a ação principal do acontecimento, mas se coloca apenas como um impedimento para a sua realização, lhe injetando mais tensão.

Todo acontecimento possui uma causa, sendo um efeito produzido por essa causa, ou seja, uma circunstância que pode ter sido acontecimento e que se transformou em causa de outro acontecimento. Na análise seqüencial dos acontecimentos, há um processo ininterrupto de causas e efeitos, sendo necessário que o diretor faça uma seleção cuidadosa, através de valorizações, para determinar o que é acontecimento e o que é circunstância, os quais estão intimamente relacionados.

A concretização de um acontecimento se dá por meio de um processo de transformação, que é precedida por sinais, que vão do mais baixo até o mais alto, isso é, do menos significativo ao mais significativo. Há uma evolução qualitativa de reconhecimentos através de avaliações dos fatos que geram mudanças no comportamento das personagens, o que dá outra direção à ação, surgindo outra circunstância, que gera outro acontecimento.

De acordo com Sulímov, a valorização por meio dos sinais "é um processo psicológico de compreensão do ocorrido, tendo como ponto de partida a própria espontaneidade, quase instintiva, o sentimento sobre a impressão do fato", ${ }^{70}$

Com o surgimento de uma nova circunstância, que dá origem a outro acontecimento, inicia um novo processo de luta, para vencer, naquele dado momento, os novos obstáculos que impedem a realização do objetivo imediato e, conseqüentemente, do superobjetivo. De acontecimento em acontecimento, com a superação dos obstáculos que aparecem, as personagens vão lutando contra as circunstâncias dadas, para alcançar o superobjetivo, e realizando a linha transversal de ação.

\footnotetext{
${ }^{70}$ SULÍMOV, M. V. Regissior naediné s piéssoi, 1999 (O diretor em solidão com a peça). Mundo virtual www.domika dramaturga. 03/2002, p.22.
} 
O acontecimento, como categoria do singular, encontra-se situado dentro do pequeno círculo da história, pois esta é representada como concretização de uma totalidade, que chamamos de médio círculo. A história está contida dentro do grande círculo e é representada pelo médio círculo, que faz parte da categoria do particular, que inicia com a principal circunstância dada e se realiza desde o acontecimento fundamental até a conclusão do acontecimento central.

Fazem parte do médio círculo todos os acontecimentos singulares, seqüenciais, necessários para contar a história, desde o fundamental até o central, situando-se entre o acontecimento inicial e o acontecimento final. O médio círculo é constituído de pequenos círculos, que representam os acontecimentos seqüenciais através dos quais a história está sendo contada. Se, no plano geral da obra, temos os acontecimentos essenciais, designados por inicial, fundamental, central e final, no pequeno círculo, no acontecimento singular, essa estrutura do grande círculo se reflete em seu núcleo, como unidade intrínseca.

Na análise da ação da obra, esse critério ajuda a detectar os elementos que fazem parte de cada acontecimento singular, os quais, na prática, devem ser concretizados pela ação por meio do processo de valorização desses elementos, ou seja, das unidades que formam as etapas dramáticas do acontecimento, da ação dramática, que possui os momentos: inicial, fundamental, central e final.

Essa forma de desvelar o acontecimento e identificar os momentos de evolução e tensão da ação, que traz à tona o conflito, através do processo de luta entre as circunstâncias dadas e o objetivo que é almejado, é muito importante na prática cênica, não só por evitar a ilustração, mas por imprimir dinâmica e tensão no processo de desenvolvimento da ação pelas suas valorizações, mudanças e superações.

Há uma evolução qualitativa dessa luta até chegar ao máximo da tensão para uma transformação final, sendo os sinais que impulsionam esse desvelamento da ação até o final. Nesse processo de luta, ocorre a junção e valorizações, por parte do ator, dos sinais revelados, que levam a tensão ao ápice quando uma nova circunstância se instala, determinando um novo acontecimento.

Aristóteles chama de peripécias esses elementos existentes na dramaturgia que, com o seu surgimento, fazem que ocorra a revelação da causa, da qual resultam o reconhecimento e as mudanças.

K. Stanislávski estabeleceu que esses elementos fossem exteriorizados fisicamente pelo ator, por meio da segmentação da ação, o que forma as células da 
partitura da ação do papel, as micromudanças causadas pela entrada de novas circunstâncias, que se constituem em obstáculos e revelam os sinais, que dão um novo sentido ao desenrolar da ação. Eugênio $\operatorname{Barba}^{71}$ (1936- ) também identifica esses elementos de transformação, existentes no material textual, e os toma como um paradigma para a dramaturgia do ator, que através de peripécias e mudanças contínuas, compõe o desenvolvimento da situação dramática:

Os saltos do pensamento podem ser definidos como peripécias ou mutabilidade. 'Peripécia' é uma trama de acontecimentos que faz desenvolver uma ação por um caminho imprevisto ou faz concluí-la de modo oposto ao que começou. A peripécia atua por meio da negação: isto é o que se sabe desde o tempo de Aristóteles. ${ }^{72}$

Ocorre nesse processo de luta um nascer, crescer e morrer do acontecimento, que envolve concretamente o desvelar de todos os elementos da ação através dos choques entre as personagens, que o impregnam de uma qualidade específica em sua forma de expressão, com ritmo e atmosfera próprios.

\footnotetext{
${ }^{71}$ Eugênio Barba, diretor e pesquisador teatral, fundador do Odin Theatre e da International School of Theatre Anthropology.

${ }^{72}$ BARBA, E; SAVARESE, N. A Arte Secreta do Ator. Campinas: Hucitec, Ed. da Unicamp, 1995, p.56.
} 


\title{
CAPÍTULO II
}

\section{ELEMENTOS DO “SISTEMA” E AS ÚLTIMAS INVESTIGAÇÕES DE K. STANISLÁVSKI COM O MÉTODO DAS AÇÕES FÍSICAS SOBRE O PAPEL}

\begin{abstract}
A ação psicofísica para o ator é comparável à nota da partitura da obra para o músico. Mas o verdadeiro músico, não aquele que consegue reproduzir corretamente nos sons as notas da partitura, mas aquele que, na execução de sua obra musical, pode entregar sua alma, fundir com ela toda a sua essência. Tal pessoa nós chamamos artista-master. ${ }^{73}$
\end{abstract}

\section{A FORMAÇÃO DO ATOR CRIATIVO}

Konstantin Stanislávski, ao dar início a sua atividade pedagógica nos estúdios, foi imbuído pela forte necessidade de investigação prática dos processos artísticos, de experimentar e explorar os princípios criativos do ator, renovar o "sistema” e compartilhar com os jovens atores e diretores suas descobertas, suas próprias experiências como artista, seu conhecimento e suas realizações. A sua preocupação está manifestada na obra Lições de 'Direção' de Stanislávski, de Nicolai M. Gorchakov (1898-1958), quando confessa estar preocupado com a educação dos novos atores e diretores, que futuramente irão assumir o lugar que hoje ele ocupa entre outros artistas famosos.

Isso justifica, diz ele, porque se prolonga tanto em discutir os princípios gerais do trabalho do ator e do diretor, além da curiosidade de conhecer e saber quem são e como serão esses jovens que vão ocupar lugar de destaque na vida teatral russa. ${ }^{74}$ Seus ensinamentos estão plenos do desejo de contribuir e transmitir, de forma prática, o que ele havia aprendido com o seu extenso trabalho de investigação sobre si mesmo, as suas descobertas para a evolução e aperfeiçoamento artístico dos que se dedicam a arte teatral.

Na introdução sobre os estenogramas, do Estúdio de Ópera Dramática existentes na obra Stanislávski Ensaiando, I. N. Vinogradskaia (1920- ), afirma que:

\footnotetext{
${ }^{73}$ KEDROV, M. N. Stat'i, retchi (Ensaios e discursos). Moscou: VTO, 1978, p.26.

${ }^{74}$ JIMENEZ, S. (org.) El Evanagelio de Stanislávski segun sus apostoles, los apócrifos, la reforma, los falsos profetas y Judas Iscariote. México: Gaceta, 1990, p.115.
} 
Stanislávski foi discípulo obstinado na busca de transformar na vida, na prática do teatro sua revelação na esfera do ator artístico. Ele queimava de desejo de deixar para as futuras gerações encontrarem o caminho orgânico para a concretização da imagem do ator, mas o processo artístico para ele não se aliava ao raciocínio frio e ao pedantismo. A educação artística da juventude não se coaduna com a ausência de talento e sensibilidade artística do pedagogo. ${ }^{75}$

Os seus conceitos sobre a arte teatral constituem a soma de toda a sua vida dedicada a essa arte, quer como ator, quer como diretor e pedagogo.

Ele parte do princípio de que todo o ser humano possui em si as faculdades da criação, sendo que a tarefa do mestre consiste em despertar o entusiasmo para a análise da natureza dessas faculdades. Afirma que o "sistema” não foi inventado, mas tomado da vida, das suas observações pessoais sobre a natureza das faculdades da criação que atuam no teatro, e está destinado aos que estão dispostos a dar um amor ilimitado a essa arte e se dedicar às qualidades do espírito e do coração. O “sistema” se dedica ao estudo da natureza das faculdades e sentimentos inerentes ao homem.

Apesar de K. Stanislávski afirmar a arte como uma forma de expressão individual e de conceber que as faculdades da criação que cada homem carrega dentro de si seguem um desenvolvimento pessoal, fundamenta seu "sistema” nos problemas de natureza geral, que podem ser aplicados igualmente a todos os artistas criadores, os quais neles podem buscar a natureza das faculdades criativas que carregam dentro de si. Para ele, a arte está contida no próprio ser do indivíduo, e o caminho para ela só é possível ser aberto através de si mesmo. Isso leva a necessidade de um trabalho prático constante sobre si mesmo, para o desenvolvimento das faculdades e qualidades internas e dos movimentos do corpo que correspondem a essas faculdades. O trabalho sobre os elementos do "sistema” objetiva a perfeição e procura encontrar e descobrir a natureza dessas faculdades, através de meios para purificá-las e desenvolvê-las, a fim de que o ator encontre a beleza e a perfeição, desenvolvendo uma metodologia que contemple a individualidade artística.

O desenvolvimento interior e exterior, ou seja, espiritual e técnico, é adquirido com base nos novos princípios da arte da criação. Esses levam à organicidade, à naturalidade na atuação e a sentimentos e pensamentos autênticos, repletos de beleza. O talento é o resultado do desenvolvimento pleno das forças humanas contidas no ator e

\footnotetext{
${ }^{75}$ VINOGRADSKAIA, I. N. (org.) Stanislávski Repetíruet (Stanislávski ensaiando). Moscou: MKHT, 2000, p.441.
} 
no seu amor desinteressado e puro pela arte, empenho, dedicação e constante treinamento de seu aparato psicofísico.

O trabalho de metamorfose total do ator, conforme o aforismo de Puchkin, “para apresentação das paixões nas circunstâncias dadas”, exige anos de trabalho dedicados a exercícios físicos e espirituais, disciplina e mudança de hábitos, levando o ator a criar em si uma segunda natureza: uma natureza de ordem física, espiritual e emocional. O “sistema”, em seus princípios e fundamentos, ensina o ator a fundir a ação física com a psíquica, criando uma completa harmonia do físico e do psíquico. Ele revela as riquezas ocultas que o ator abriga em seu interior, para que possa compreender a natureza do sentimento da criação através da ação física e psicológica precisa e correta.

K. Stanislávski deixa muito claro em seus ensinamentos que, em arte, "saber é saber fazer", e seu "sistema” mostra como buscar o melhor caminho para conseguir a natureza do sentimento criativo, através de seus elementos externos e internos, para poder atingir a verdadeira arte, que é alcançada pelo novo ator autônomo e criativo. Fabrizio Cruciani ${ }^{76}$ (1941-1992) fala das críticas a K. Stanislávski sobre o abandono do teatro calcado na palavra, no qual o ator tinha a função maior de “ilustrar" o texto, contraposto ao teatro do corpo e esclarece:

Pela ação do ator ser mais 'interior' e 'psicológica'- como normalmente se pensa em relação a Stanislávski - ou mais 'física' e projetada para o 'externo', não era essa a questão essencial. Essencial era a revolução que estava sendo operada no palco cênico: não era mais o ator a serviço do texto escrito, mas o texto escrito a serviço do ator. ${ }^{77}$

Dos inúmeros estúdios que K. Stanislávski manteve destinados a investigação e experimentação do "sistema”, além do de 1905, dirigido por Meyerhold, uns ligados ao TAM, outros independentes, foi possível reunir um conhecimento sistematizado, que se compõe de formulações teóricas e de um arsenal de exercícios para a prática, os quais permitem dar conta da complexa formação do novo ator, proporcionando uma educação espiritual e técnica. Essa sistematização foi desenvolvida através dos chamados

\footnotetext{
${ }^{76}$ Professor na Universidade de Bologna e de Lecce, em Problemas de Historiografia do Espetáculo e História do Teatro e do Espetáculo, membro do Staf científico do ISTA, pesquisou e publicou sobre o teatro renascentista e a reforma teatral do Novecentos, o teatro criativo de K. Stanislávski, entre outras publicações.

${ }_{77}$ CRUCIANI, F. Registi Pedagoghi e Comunità Teatrale nel Novecento. Roma: E\&A editori associati, 1995, p.117.
} 
elementos do "sistema", nos quais está contida a chave do ato criativo para quem se entregar totalmente a desenvolver em si mesmo as qualidades artísticas essenciais inerentes à arte teatral. Esses elementos são considerados uma espécie de gramática da arte do ator, abrindo e desenvolvendo o seu talento, e têm valor universal, pois suas bases fundam-se na natureza humana, e por isso o mestre os chamou de leis da natureza orgânica do homem em ação.

Citamos Camilo Scandolara ${ }^{78}$ sobre a importância dos estúdios no desenvolvimento do “sistema”, através da prática dos exercícios:

[...] os estúdios foram, por excelência, os locais de surgimento e desenvolvimento dos exercícios. São, portanto, fundamentais para compreendermos o surgimento de uma nova dimensão do trabalho do ator, que, sem dúvida, revolucionou também a maneira de se pensar o fazer teatral. $O$ sentido do ofício, aquilo que permite a alguém se intitular ator, passa a não mais residir, pelo menos não mais somente, na apresentação de espetáculos públicos. Afirma-se pela primeira vez de maneira explícita a necessidade de uma prática de exercícios como base para o trabalho criativo do ator. E principalmente, este espaço do exercício, do trabalho cotidiano, passa a ser visto como o espaço de construção da identidade profissional e artística do ator. Esse novo enfoque teve profunda influência sobre o desenvolvimento da prática e da teoria teatral do século $X X{ }^{79}$

K. Stanislávski se ressentia pelo fato de o teatro ser a única arte que não possuía um instrumental teórico-prático sistematizado para desenvolver as qualidades artísticas daquele que queria se dedicar à arte teatral. $\mathrm{O}$ ator só podia contar com sua boa-vontade, sua intuição, sua inspiração e seu talento. O músico e o pintor possuíam um conjunto de princípios e exercícios que faziam parte da alfabetização nessas áreas. Essa inquietação levou K. Stanislávski a buscar fundamentos sólidos, em que o ator pudesse se apoiar, além de sua própria natureza espontânea e criativa. Foi essencialmente pela observação pertinaz de si mesmo e dos grandes artistas, além da observação da natureza humana e da vida que K. Stanislávski construiu o seu “sistema”, que tem como base o domínio dos elementos da ação cênica. Através de intenso estudo sobre si mesmo e do treinamento constante dos elementos quer trazer à tona a verdadeira inspiração, proporcionada pela total atenção e concentração no trabalho. O desenvolvimento

\footnotetext{
${ }^{78}$ Camilo Scandolara, ator e diretor, graduado na UFSM. Atualmente professor de teatro na U.E.Londrina $-\mathrm{PR}$.

${ }^{79}$ SCANDOLARA, C. "Os estúdios do Teatro de Arte de Moscou e a formação pedagógica teatral no século XX” - Dissertação de mestrado, Universidade Estadual de Campinas, Instituto de Artes, Campinas, 2006, p.162.
} 
individual das faculdades humanas universais é possibilitado pelo treinamento de seu “sistema”, o qual permite ao ator dirigir sua imaginação de forma controlada e guiá-la exclusivamente para a criação. K. Stanislávski propunha uma liberação do “eu” criativo do ator de todas as amarras da vida cotidiana, do "eu” egoísta, do orgulho, da vaidade que o colocam em constante luta consigo mesmo.

Estabeleceu que sem uma férrea disciplina sobre si mesmo seria impossível ao ator iniciar na nova arte de atuar. Essa disciplina começaria pelo desenvolvimento da concentração.

\section{Concentração}

O elemento concentração é fundamental e necessário para a criação. Ele envolve a observação, a percepção, a imaginação, a memória e a vontade. O desenvolvimento da faculdade de observação e percepção exige uma mente flexível e aberta, capaz de concentração absoluta, que possibilite o domínio consciente e voluntário da atenção, levando o ator a concentrar todo o seu aparato psicofísico ativamente numa única direção, no objeto escolhido. A ação de concentrar a atenção num objeto aguça a capacidade de percepção e de observação e leva à essência das coisas. Obriga a atenção a penetrar profundamente no objeto observado, a avaliá-lo e captar a sua essência. Com um esforço de vontade, o ator deve encontrar na vida, através da observação, o essencial, o característico, deve captar tudo o que ocorre ao seu redor e eleger aquilo que é mais significativo, interessante e típico. A observação da vida e de si mesmo inclui um vasto trabalho sobre os cinco sentidos, que, segundo K. Stanislávski, liberam o sexto sentido, a intuição e a inspiração. $\mathrm{O}$ ator deve adquirir o hábito de dirigir sua atenção a todas as manifestações da vida, desenvolver a faculdade consciente de observação de tudo o que ocorre dentro e fora dele. Essa observação não pode ser superficial, mas o ator deve descobrir no objeto observado algo ainda não percebido, os detalhes, aprofundando assim todas as peculiaridades únicas do objeto em questão, sob os aspectos da textura, cheiro, forma, cor, movimento, ritmo, etc.

A esfera da atenção exige uma dedicação intensa, tempo para habituar-se a olhar, ver, escutar, ouvir, e conseguir "relatar" de forma viva o que foi percebido. O ator deve procurar distinguir pelo rosto, pelo olhar, pelo timbre da voz o estado de ânimo do interlocutor e, para isso, precisa realmente olhar e escutar ativamente a complexidade da vida. Ter uma aguda atenção ajuda a captar as características mais sutis, imperceptíveis da vida e das pessoas. K. Stanislávski refere-se às dificuldades de compreender a 
essência da vida do ser humano por sua característica invisível, mas propõe a utilização dos recursos de observação das expressões da face, da mímica, das atitudes, dos olhos, da voz, da fala, dos movimentos do corpo, que ajudam a apreender a vida interior, a descobrir o mundo interior do ser humano. Por meio de atitudes, idéias, impulsos e ações determinadas pelas circunstâncias da vida, o ator deve fazer o possível para captar as características do espírito das pessoas que são objeto de observação.

K. Stanislávski aconselha a buscar, nas coisas e no ser humano, o seu lado positivo e o negativo, o belo e o feio, e aprender a distingui-los, gravar as impressões do observado com a mente e com o coração, com os sentimentos. O espírito observador do artista deve penetrar em tudo o que ocorre na realidade ao seu redor: nos ambientes, nos objetos animados e inanimados que despertam a atenção, a curiosidade, a imaginação, e provocam a emoção, impulsionando-o a formular perguntas, investigar, adivinhar e observar. Os objetos são sinais que levam a suposições, a conjunturas da imaginação agregadas a eles, aguçando, assim, o interesse pelos mesmos. A observação realizada com interesse gera uma atenção dirigida e concentrada com clareza, precisão e agudeza, enriquecida pela imaginação.

O aspecto prático da função da atenção artística consiste em que o ator deve observar tudo o que ocorre em cena, deve concentrar-se com todo o seu ser no objeto de atenção e observá-lo com agudeza. A concentração é o primeiro alicerce, o germe da criação. Para o ator, a observação da vida sob todos os seus aspectos e a apreensão das impressões obtidas nela, através da comunicação direta com o que é visto, ouvido e percebido, constituem elementos e material necessários que passam a ser fonte de inspiração para a criação de imagens cênicas vivas. Esse material sensitivo-emocional é valioso para dar forma à “vida do espírito humano do papel”, objetivo principal da arte teatral.

O “sistema” propõe, através de exercícios, trabalhar exaustivamente a disciplina do pensamento para o desenvolvimento da concentração cênica. Na concentração da atenção, se estabelece uma condição, um estado, que leva a uma ação interior ativa do pensamento. K. Stanislávski ${ }^{80}$ destaca o caráter ativo da atenção cênica, que se revela através dos círculos de atenção. É uma atividade voluntária do pensamento possibilitada pela concentração da atenção em um único objeto ou idéia, dentro do inquebrantável

80 STANISLÁVSKI, K. Sobránie sotchinénii v 8 tomakh, 1954-1961. Rabota aktiora nad soboi. Rabota nad soboi $v$ tvórtcheskom protsésse perejivânia (O trabalho do ator sobre si mesmo. O trabalho sobre si mesmo no processo da criação da vivência). Tomo 2, Moscou: Iskusstvo, 1954, pp.108-118. 
círculo de atenção. Este obriga o ator a se colocar totalmente imerso, com toda a sua capacidade afetiva, intelectual e física, na ação interna e externa que está realizando cenicamente. A obtenção desse estado orgânico de criação é possibilitado pelo desenvolvimento da concentração, por essa capacidade de dirigi-la exclusivamente, sem esforço, para o círculo de atenção, exigindo o comprometimento total do ser do ator, de forma precisa e eficaz, no qual permanece em solidão pública, para o cumprimento da tarefa que lhe é solicitada.

Para isso, o ator deve fazer todo o possível para desenvolver e controlar sua atenção e poder centrá-la, conforme sua vontade, sobre certo objeto interno ou externo e, então, entrará no círculo de solidão pública sem esforço. O círculo de solidão pública exige toda a concentração, da atenção dos pensamentos, voltados para dentro do círculo de atenção, advindo daí o seu poder e força de atração sobre o público. K. Stanislávski esclarece para os atores que: “É pública porque o público está com vocês e é solidão porque vocês estão separados do público pelo pequeno círculo de atenção que criaram". 81

O chamado círculo de atenção é um espaço traçado pela visão do ator no qual pode haver muitos objetos, pontos ou focos. Sobre eles o ator pode dirigir a sua atenção, dentro do limite estabelecido do círculo. Os círculos de atenção se tornam relativos conforme a ação que se desenvolve no espaço. K. Stanislávski determinou que a extensão dos espaços internos e externos do círculo de atenção fossem definidos como pequeno, médio e grande círculo.

O pequeno círculo é um espaço íntimo do ator, onde se realizam ações próximas, de caráter complexo e singular, seja com o objeto, com o espaço, consigo mesmo, com o pensamento ou com o partner. Pela sua característica espacial condensada, ele permite ao ator experimentar em cena, diante do público, o isolamento de tudo aquilo que está fora do limite determinado pelo pequeno círculo.

O médio círculo amplia a extensão da área de visibilidade da atenção e pertence ao particular, ou seja, abarca o espaço da atuação do jogo cênico, onde estão contidos os pequenos círculos de atenção com seus objetos de atenção.

No grande círculo, a linha do círculo imaginário traçada é ampliada; possui caráter universal. É o lugar das grandes idéias, memórias, reflexões que se realizam pela

\footnotetext{
${ }^{81}$ STANISLÁVSKI, K. Sobránie sotchinénii v 8 tomakh, 1954-1961. Rabota aktiora nad soboi. Rabota nad soboi $v$ tvórtcheskom protsésse perejivânia (O trabalho do ator sobre si mesmo. O trabalho sobre si mesmo no processo da criação da vivência). Tomo 2, Moscou: Iskusstvo, 1954, p.109.
} 
visualização das imagens do pensamento que o ator projeta externamente. Esses limites dependem de convenções dadas pelo diretor, pelo texto e pelo próprio imaginário do ator, ao estabelecer e relativizar os espaços em que atua e os objetos cênicos concretos ou imaginários de sua atenção num determinado momento.

K. Stanislávski propõe que, quando o ator percebe que a sua concentração está se diluindo, e para evitar uma atuação geral, ele deve voltar ao círculo menor possível de ser abarcado pela sua atenção visual, mantendo a atenção dentro dos limites da linha fixada. "Se te perderes em um círculo grande, refugia-te imediatamente em um pequeno". 82

Esse recurso de transição de um círculo a outro, ampliando o espaço da visão do pequeno para o grande e vice e versa, exige do ator controle absoluto na condução de sua atenção, para que ele possa obter fluência na passagem de um círculo de atenção para outro. Com a capacidade de transitar nos círculos de atenção, de atrair e governar a atenção com a ajuda de um objeto de atenção, o ator passa a atuar concretamente de forma eficaz e orgânica em cada momento de sua presença cênica. Com a aquisição do hábito mecânico e inconsciente de fluir pelo pequeno, médio e grande círculo, sem debilitar a atenção, a solidão pública se torna uma necessidade natural.

O olhar dirigido à platéia é determinado pelas circunstâncias dadas do papel, quer essas advenham do texto, ou de indicações da direção, quer da invenção do ator, e é possibilitado pela ampliação do círculo de atenção. $\mathrm{O}$ ator deve compreender o significado do espaço para o ângulo da visão em cena e, com o domínio da técnica, aprender a colocar um objeto concreto ou imaginário no lugar exato determinado pela vontade e fixar nele a atenção.

Os objetos de atenção podem ser exteriores ou interiores, podendo advir de um objeto externo ou de uma imagem que provoca outras sensações, como o gosto, o cheiro, o som, que se produzem internamente. O objeto da vida imaginária chega indiretamente através de um objeto auxiliar, externo, que é aquilo que acontece com os cinco sentidos. A atenção se dirige para determinado lugar e daí surgem representações visuais, que originam uma sensação interior. $\mathrm{O}$ material da atenção interior advém da imensidão de impressões de toda a nossa vida real que existem e permanecem em nossa memória sensitiva, corporal, afetiva e intelectual e, sobretudo, da vida

\footnotetext{
${ }^{82}$ STANISLÁVSKI, K. Sobránie sotchinénii v 8 tomakh, 1954-1961. Rabota aktiora nad soboi. Rabota nad soboi $v$ tvórtcheskom protsésse perejivânia (O trabalho do ator sobre si mesmo. O trabalho sobre si mesmo no processo da criação da vivência). Tomo 2, Moscou: Iskusstvo, 1954, p.116.
} 
imaginária, possível de existência real ou não. Os objetos da vida imaginária são instáveis e frágeis, por isso exigem uma atenção muito exercitada para que se tornem acessíveis e concretos.

Para conseguir a estabilidade do objeto na atenção interior, o procedimento técnico deve ser o mesmo que para a atenção exterior, isto é, valer-se dos objetos de atenção dentro dos círculos de atenção, pequenos, médios, grandes, móveis e imóveis. Para o desenvolvimento da ação interior, é necessário o treino mental com os mesmos exercícios da atenção exterior. Somente com o adestramento interno prolongado e sistemático da atenção exterior e interior, o ator consegue uma concentração produtiva, aguda, estável e poderosa. A importância da atenção interior é fundamental para o processo de criação, pois o mesmo se realiza no plano da ficção, pelas circunstâncias dadas, por meio da imaginação, e somente é acessível à atenção interior.

Para o trabalho diário e consciente, há a exigência de uma disciplina que requer força de vontade, firmeza e domínio de si mesmo. K. Stanislávski ${ }^{83}$ diz que, em arte, a atenção e os objetos devem ser estáveis, por isso a criação exige a concentração de todo organismo do ator, e afirma que o que atrai a atenção em cena não é o objeto em si, mas aquilo que a imaginação forjou. Com a ajuda das circunstâncias dadas, o objeto toma novo significado e se torna atraente, transformado-se em estímulo para a criação, pois, pela observação detalhada e concentrada, o objeto excita a imaginação. Ao orientar a atenção sobre determinado objeto, surgem idéias relativas a ele que instigam a imaginação, e isso desperta o desejo de atuar.

Os princípios da ação exigem a aceitação do objeto, a crença nele, que resulta na relação com o mesmo, e então inicia-se a transformação do objeto. A aceitação do objeto, a crença, é o "se” que exige uma resposta humana, estabelece um objetivo, que gera uma ação e leva a uma nova relação. O surgimento da pergunta, diante do objeto, “o que fazer?”, torna-o mais importante, sedutor e hipnótico. Através da presença ativa da imaginação, o objeto transforma-se e cria-se, assim, uma reação interior afetiva produzindo uma atividade criativa com o objeto. A atenção está sempre ligada à percepção, ao trabalho do pensamento e da vontade sobre a imaginação que gera a necessidade de uma atitude de interesse diante do objeto. Ruffini (1939- ) aponta, como mais um paradoxo do teatro de K. Stanislávski, essa ajuda da atenção para excitar a

\footnotetext{
${ }^{83}$ STANISLÁVSKI, K. Sobránie sotchinénii v 8 tomakh, 1954-1961. Rabota aktiora nad soboi. Rabota nad soboi $v$ tvórtcheskom protsésse perejivânia (O trabalho do ator sobre si mesmo. O trabalho sobre si mesmo no processo da criação da vivência). Tomo 2, Moscou: Iskusstvo, 1954, p.117.
} 
imaginação: "Se para um objeto real se trata de prestar atenção a cada detalhe, para um objeto real da ficção se trata de criar os detalhes, mediante a atenção que se dá a eles". 84

Em cena, no momento da atuação no papel, o ator necessita de uma ação centrada e alerta, pois há a exigência de ter vários objetos de atenção simultânea, que são os procedimentos técnicos, a relação com o partner, com os objetos cênicos e com o espectador. K. Stanislávski diz que isso é possível porque a "atenção do ser humano" foi formada por múltiplos planos que não se interferem. ${ }^{85}$

O controle eficaz do ator, para poder manter fixa a atenção no principal objeto de atenção, exigido no momento da atuação, e ao mesmo tempo conservar as "antenas" de seu aparato sensitivo e perceptivo alerta a todas as circunstâncias existentes no aqui e no agora do jogo cênico, só é conquistado pelo trabalho incessante sobre si mesmo. Esse trabalho leva ao adestramento, condicionamento e condução da atenção conforme a vontade, pois aquilo que é habitual torna-se automático. É a aquisição de uma segunda natureza, que se revela pela precisão na ação, exigência do “sistema” de K. Stanislávski.

Por isso, o desenvolvimento de uma atenção ininterrupta e indivisível, constitui a base fundamental dos recursos técnicos e das faculdades internas, espirituais, para aquele que quer se tornar ator. Essa capacidade, adquirida através de exercícios práticos, possibilita ao ator dimensionar o seu talento artístico, levando-o a utilizá-lo como meio de expressão.

O domínio da arte da concentração, o seu constante desenvolvimento, leva o ator a discernir o que é essencial na natureza das coisas e das pessoas, a obter o máximo controle sobre seu corpo e sua mente e, conseqüentemente, conquistar um aperfeiçoamento na sua percepção do mundo, na sua sensibilidade, e uma alteração qualitativa em sua consciência. Portanto há uma elevação como artista e como ser humano, pois não há separação entre sua atitude no teatro e na vida: elas se coadunam.

Para essa finalidade, os meios metodológicos de ajuda a serem aplicados devem transcorrer dentro de uma atmosfera de entusiasmo, alegria, interesse e profunda serenidade, possibilitando que a atenção se converta no principal estímulo na vida do ator e na sua criação, que, a cada momento, exige novas adaptações.

\footnotetext{
${ }^{84}$ RUFFINI, F. Stanislavskij: Dal lavoro dell'attore al lavoro su di sé. Roma: Laterza, 2003, p.48.

${ }^{85}$ STANISLÁVSKI, K. Sobránie sotchinénii v 8 tomakh, 1954-1961. Rabota aktiora nad soboi. Rabota nad soboi $v$ tvórtcheskom protsésse perejivânia (O trabalho do ator sobre si mesmo. O trabalho sobre si mesmo no processo da criação da vivência). Tomo 2, Moscou: Iskusstvo, 1954, p.123.
} 


\section{Imaginação}

A imaginação e a concentração são elementos considerados por K. Stanislávski essenciais no processo de criação, pois eles são imprescindíveis para o fazer artístico, e a própria arte não existe sem eles. O artista, conscientemente ou inconscientemente, seleciona constantemente imagens fundamentais que povoam a sua mente e que constituem material para o seu trabalho criativo. A imaginação, para o ator, tal qual a atenção, pode ser desenvolvida e direcionada exclusivamente para o ato criativo. K. Stanislávski estabeleceu uma diferença entre imaginação e fantasia:

A imaginação cria aquilo que é, o que acontece, o que conhecemos; a fantasia, porém, nos mostra o que não existe, o que realmente jamais existiu nem aconteceu [...] ainda que possa acontecer. ${ }^{86}$

Tanto a imaginação quanto a fantasia são indispensáveis para o artista. A diferença fundamental entre fantasia e imaginação é a participação ativa do sujeito-ator que a imaginação exige, no momento dado da realização de determinada tarefa. A fantasia, considerada absoluta em seu saber e poder, porém passiva, pode se transformar em imaginação no momento em que o ator se torna agente e a concretiza através de uma ação. K. Stanislávski quer para o ator uma imaginação produtiva que se estabeleça, através de um treino sistemático, como uma alavanca que impulsiona a criação, despertando o inconsciente e a intuição, levando-o à ação e indiretamente podendo despertar os sentimentos. Assim, a imaginação junto com a atenção torna-se psicotécnica sensorial.

Diante dessa necessidade de uma imaginação ativa, o ator é levado, por meio de exercícios, a participar de invenções propostas, reagindo fisicamente e psiquicamente ao jogo, como se fosse real, o que exige a ingenuidade da criança. A imaginação no ator não pode ser geral, ela tem que se constituir num poder para sugerir imagens claras, definidas e concretas para a criação. No processo criativo, a imaginação do ator precisa ser estimulada com um objetivo interessante para que os pensamentos se tornem ativos e gerem ações internas e externas concretas. K. Stanislávski fala dessa participação ativa do ator na vida criada pela imaginação e do seu estado ativo, o "eu sou”, que se apropria de todo o ser do ator e exige o comprometimento de toda a sua natureza:

\footnotetext{
${ }^{86}$ STANISLÁVSKI, K. Sobránie sotchinénii v 8 tomakh, 1954-1961. Rabota aktiora nad soboi. Rabota nad soboi $v$ tvórtcheskom protsésse perejivânia (O trabalho do ator sobre si mesmo. O trabalho sobre si mesmo no processo da criação da vivência). Tomo 2, Moscou: Iskusstvo, 1954, p.70.
} 
Estabelecer o 'eu sou', em nossa linguagem, indica que me coloquei no centro das condições imaginárias, sinto que me encontro entre elas, que eu existo no mais denso da vida da imaginação, no mundo dos objetos imaginários, e que começo a atuar movido pelos meus próprios impulsos. ${ }^{87}$

K. Stanislávski afirma que a fantasia “em geral” sem um tema proposto é inútil, pois para a criação de imagens é necessário que a imaginação seja submetida a uma atividade mental, porém adverte, que, por outro lado, uma imaginação produzida de forma consciente e racionalizada pode ser estéril, pode faltar-lhe vida.

O ator tem que inquietar a imaginação formulando perguntas simples, para ativála e aproximar o objeto de investigação à sua mente por meio de uma lógica coerente. As perguntas quem? o quê? por quê? quando? onde? como? o que faz? o que vê? de que é feito? como é? etc., feitas sobre o objeto pesquisado, ajudam a despertar a imaginação e levam a criar imagens vivas definidas e claras. À pergunta “para quê?”, também é atribuída grande importância, pois "ela obriga a esclarecer o objetivo das nossas aspirações, e isso nos indica o futuro e nos impulsiona à atividade, à ação". ${ }^{88}$

Aos temas propostos através de exercícios para desenvolver a imaginação mediante o processo de aceitação das invenções com o “se”, K. Stanislávski sugere que seja aplicada a pergunta-chave: “Que faria eu em tais circunstâncias dadas?”, pois ela desperta a imaginação, estabelecendo o "se” mágico, e já coloca os procedimentos técnicos para a futura criação do papel. Exigia que nos exercícios fossem esgotadas todas as possibilidades de exploração e aperfeiçoamento, considerando que os exercícios inacabados eram prejudicais para o desenvolvimento artístico do ator. Um único exercício poderia ser renovado dezenas de vezes totalmente ou, em parte, por uma nova idéia e não poderia ser aplicado formalmente, como um mero cumprimento de tarefas ou para preencher um "fazer de conta” pedagógico.

No seu processo pedagógico, exortava o ator a estar sempre disponível para aceitar as proposições sugeridas; lutava para que o ator estivesse aberto para as possibilidades da vida imaginária, pois a técnica amplamente utilizada por ele, como meio de criação era a improvisação. Esta exige do ator não a rigidez de idéias e atitudes, mas uma mente volátil, ágil e alerta, capaz de responder, imediatamente, aos estímulos

\footnotetext{
${ }^{87}$ STANISLÁVSKI, K. Sobránie sotchinénii v 8 tomakh, 1954-1961. Rabota aktiora nad soboi. Rabota nad soboi $v$ tvórtcheskom protsésse perejivânia (O trabalho do ator sobre si mesmo. O trabalho sobre si mesmo no processo da criação da vivência). Tomo 2, Moscou: Iskusstvo, 1954, p.79.

${ }^{88}$ Ibidem, p.91.
} 
com a ação. Para dar sentido e interesse ao "jogo", o ator tem que acreditar nas proposições do mesmo, desenvolvendo-o na perspectiva não do "confronto", mas do “acordo”, da receptividade e reciprocidade. A improvisação exige do ator, além do envolvimento de seu imaginário interno, o comprometimento total de seu aparato sensorial de forma ativa, que o possibilite prever e dar respostas inusitadas ao problema e que expressem a fé naquilo que é vivenciado por meio de ações físicas coerentes e verazes.

Considerando que a percepção da realidade está intimamente ligada à individualidade artística, o ângulo de visão do ator sobre a mesma ocorre conforme sua capacidade de imaginação e fantasia. O papel da imaginação no trabalho de criação do ator se dá, sobretudo, através do "se” mágico e das circunstâncias dadas pelo autor. Sobre essa imensa responsabilidade artística do ator K. Stanislávski sentencia: “A tarefa do ator e de sua técnica artística consiste em transformar a idéia da obra em acontecimento artístico da cena" ${ }^{89}$ Para o ator poder realizar essa enorme incumbência tem que se transportar para o plano de uma vida suposta e inexistente com a ajuda das circunstâncias dadas e do mágico "se” e para isso ele necessita de uma imaginação ativa que concretize essa "realidade” criada pela ficção. Ruffini fala sobre a exigência do mestre em relação à aparente contradição entre fantasia e imaginação:

A imaginação, segundo Stanislávski, é justamente o contrário do lugar-comum. Não se alimenta tirando o freio à fantasia, mas, ao contrário, pondo-lhe freios continuamente; nisto consiste o caminho da precisão; não serve para se perder em outro mundo mas para entrar, e situar-se no outro mundo, da ficção. ${ }^{90}$

O ator deve preencher com a sua imaginação todos os espaços obscuros da personagem, não esclarecidos pelo autor na obra e, em particular, no papel, pois ele deve justificar para si toda a vida da personagem com uma imagem íntegra, externa e interna, que abrange o caráter, as idéias, os sentimentos, os impulsos, as ações da personagem criada por ele. Somada a essas exigências complexas da obra, há a inclusão de novas circunstâncias, colocadas pela própria imaginação do ator e dadas também pelo diretor, as quais exigem uma imaginação penetrante, apurada e ágil, com sugestões criativas que levam a novas soluções, acrescentando assim elementos originais ao

\footnotetext{
${ }^{89}$ STANISLÁVSKI, K. Sobránie sotchinénii v 8 tomakh, 1954-1961. Rabota aktiora nad soboi. Rabota nad soboi $v$ tvórtcheskom protsésse perejivânia (O trabalho do ator sobre si mesmo. O trabalho sobre si mesmo no processo da criação da vivência). Tomo 2, Moscou: Iskusstvo, 1954, p.69.

${ }^{90}$ RUFFINI, F. Stanislavskij: Dal lavoro dell'attore al lavoro su di sé. Roma: Laterza, 2003, p.46.
} 
processo do trabalho e a criação como um todo. O trabalho de criação exige todas as forças do ser do ator, da sua imaginação e da sua criatividade, voltadas para obter a totalidade da vida da personagem na imaginação, tornando-se seu criador absoluto, e é nisso que se constitui o seu segredo.

No desenvolvimento da imaginação de forma lógica e contínua dirigida a um fim, o maior desafio para o ator, dentro dessa psicotécnica, é criar o filme de imagens que vão dar vida à personagem no papel. Essa complexa tarefa do ator, a de criar o filme de imagens da vida da personagem em sua visão interna, exige o máximo potencial de sua imaginação, para a projeção externa dessas imagens no momento da comunicação do papel. O filme de visualizações se constitui de todo o material acumulado e fixado de imagens sobre a personagem que transcendem o papel, que ilustram as circunstâncias dadas da obra, o "se” mágico, o subtexto, expressos na comunicação com o partner, nos monólogos e nos momentos de imobilidade, criados pelo ator.

Para K. Stanislávski, as “visões” englobam todo o complexo de sensações imaginárias sensoriais sobre o objeto de forma ativa. Para cada instante do ator em cena, o filme de imagens o obriga a estar presente concretamente, dirigido pela imagem como objeto de atenção dentro do seu círculo de atenção. No solilóquio e na imobilidade trágica, a imaginação do ator é exigida de forma mais densa, pois ele tem que potencializar a ação interna com o significado das imagens e tem que se comunicar com elas, estabelecendo e exteriorizando uma relação física, mental e emotiva.

A expressão da fala cênica para K. Stanislávski deve ser o resultado da ação interna e externa, a qual gera a ação da palavra, determinada pela transmissão de imagens sobre aquilo que o ator está falando e a relação psicofísica que se estabelece com as mesmas no momento da comunicação. A técnica do filme é amplamente utilizada pelo ator na fala, pois ele deve falar aquilo que enxerga pela visão interna, pela ação, isto é, para K. Stanislávski, na palavra há ação, e a ação da palavra consiste na visualização das referências sobre aquilo que o ator está falando. O mestre considera que a expressão não correta da palavra se dá pela falta de visualizações interessantes em relação àquilo que o ator está dizendo, ou seja, não está agindo corretamente com a palavra.

Para o ator obter a totalidade das imagens que criam o filme, ele necessita repetilo inúmeras vezes, até gravá-lo profundamente na memória, e isso o levará a viver 
intensamente o papel, despertando nele um estado de ânimo análogo ao que corresponde à personagem provocando os impulsos e, a partir deles, as próprias ações.

\section{O "se" mágico}

No trabalho de criação, K. Stanislávski propõe a palavra mágica “se” para o ator poder concretizar e levar a cabo as proposições das circunstâncias dadas. A pergunta antes utilizada por K. Stanislávski: “O que eu quero na presente situação?”, foi substituída por outra, que coloca o "se” diante das circunstâncias eleitas, que estabelece imediatamente o ator dentro da situação e o leva a agir concretamente: "O que eu faria se me encontrasse em tais circunstâncias?”. Isso estabelece como princípio que toda a ação é gerada não só pelo objetivo externo, mas também pelo impulso interno, por um motivo, uma causa, ou seja, pelas circunstâncias dadas que se constituem no estímulo para invenção do "se”. As circunstâncias dadas são a causa pela qual se realiza a ação, e o "se" é o impulso para a sua realização que vem do próprio ator.

O “se”, como também as circunstâncias dadas, é uma invenção, um jogo, uma suposição da imaginação, uma ficção, em que o fato proposto pode ou não acontecer na realidade da vida. K. Stanislávski esclarece que:

O 'se' sempre dá começo à criação; as circunstâncias dadas a desenvolvem. Não pode existir uma sem a outra, nem obrigatoriamente adquirir sua força de estímulo. Porém tem funções diferentes: $o$ 'se' dá um impulso à imaginação adormecida, enquanto que as 'circunstâncias dadas' dão fundamento ao 'se'. Juntos ajudam a criar o estímulo interior. ${ }^{91}$

O ator, diante de um problema proposto pelo "se", começa a agir e tenta solucionar esse problema com toda a liberdade de ação, de acordo com sua experiência de vida e o que a imaginação lhe propõe, condicionado pelas circunstâncias dadas e pela situação. O "se" constitui-se num desafio para a ação, ele estimula e dispõe o ator para o jogo, criando nele um estado ativo interior e exterior, levando-o a realizar a ação de forma produtiva e com lógica e coerência. O "se" introduz o ator num estado criativo que o leva a solucionar a tarefa que lhe foi proposta de forma natural e sem esforço. A

\footnotetext{
${ }^{91}$ STANISLÁVSKI, K. Sobránie sotchinénii v 8 tomakh, 1954-1961. Rabota aktiora nad soboi. Rabota nad soboi $v$ tvórtcheskom protsésse perejivânia (O trabalho do ator sobre si mesmo. O trabalho sobre si mesmo no processo da criação da vivência). Tomo 2, Moscou: Iskusstvo, 1954, p.62.
} 
atividade na criação e na arte é uma propriedade constitutiva do "se", tornado-se assim um dos pilares do sistema. ${ }^{92}$

K. Stanislávski declara, em uma carta à Liubòv I. Gurevitch ${ }^{93}$ (1866-1940), que, em cena, só considera criativos aqueles momentos que foram provocados pelo “'se' mágico”:

Nestes momentos não existe o papel. Só existo eu mesmo. Do papel e da obra somente ficam as condições, as circunstâncias de sua vida. Sendo todo o resto meu, próprio. Tudo me pertence, já que qualquer papel, em cada um de seus momentos criativos, pertence a um indivíduo vivo, isto é, ao artista, e não ao esquema morto de um indivíduo, isto é, o papel. ${ }^{94}$

Como podemos perceber K. Stanislávski, através do "se”, estabelece e atribui a autoria da criação cênica única e exclusivamente ao ator. O "se" é uma palavra mágica que transporta o ator para o mundo da imaginação, único espaço onde pode ser realizada a criação. Ele possui o poder de produzir um estímulo interno que leva o ator a atuar de maneira autêntica e orgânica.

K. Stanislávski qualifica o “se" em simples e complexo. O “se" simples é aquela palavra mágica que dá o impulso para o desenvolvimento lógico da criação, que provoca uma reação instantânea, leva a uma ação instintiva. É próprio de proposições de improvisações com temas e circunstâncias simples em situações que geram o jogo imediato como também em obras que não possuem circunstâncias múltiplas. Nas obras complexas, "entrelaçam-se uma grande quantidade de autores e outros variados 'se', que justificam esse ou aquele comportamento e tais ou quais atos dos heróis". 95

\section{Fé e sentido da verdade}

\section{O significado e o papel da verdade e da fé no processo da criação}

A verdade e a fé em cena exigem a participação ativa de todos os elementos da ação de forma clara, correta e harmônica. Para alcançar a autenticidade em cena, o ator

\footnotetext{
${ }^{92}$ STANISLÁVSKI, K. Sobránie sotchinénii v 8 tomakh, 1954-1961. Rabota aktiora nad soboi. Rabota nad soboi $v$ tvórtcheskom protsésse perejivânia (O trabalho do ator sobre si mesmo. O trabalho sobre si mesmo no processo da criação da vivência). Tomo 2, Moscou: Iskusstvo, 1954, pp.60-61.

${ }^{93}$ Liubòv I. Gurevitch, escritora, crítica, historiadora teatral, redatora e colaboradora na obra Minha Vida na Arte, entre outros livros de Stanislávski.

${ }^{94}$ STANISLÁVSKI, K. Sobránie sotchinéni v 8 tomakh, 1954-1961. Píś́ma 1918-1938 (Cartas 19181938). Tomo 8, Moscou: Iskusstvo, 1961, p.285.

${ }^{95}$ STANISLÁVSKI, K. Sobránie sotchinénii v 8 tomakh, 1954-1961. Rabota aktiora nad soboi. Rabota nad soboi $v$ tvórtcheskom protsésse perejivânia (O trabalho do ator sobre si mesmo. O trabalho sobre si mesmo no processo da criação da vivência). Tomo 2, Moscou: Iskusstvo, 1954, p.58.
} 
tem que colocar em movimento todas as forças criativas para realizar a ação como quando a criou pela primeira vez, não imitando o que criou, mas passando novamente pelo processo vivo orgânico da criação. Na ficção artística, a verdade e a fé surgem do trabalho de fermentação e ativação da vida imaginária. Para o ator realizar uma ação genuína, despertando em si mesmo a verdade cênica, deve transferir-se para o plano da vida imaginária, com a ajuda das circunstâncias dadas e do "se". O que torna verazes e autênticas as ações e atitudes em cena e leva à fé é o sentimento interior do ator, que as justifica sempre com os "se", com as circunstâncias dadas e com objetivos interessantes. A permanência do ator em cena deve estar constantemente ratificada pela verdade das ações que está realizando e pela fé na verdade dos sentimentos que está vivendo. K. Stanislávski diz que:

A verdade na cena é aquilo que acreditamos sinceramente que ocorre dentro de nós mesmos, internamente, como também na alma de nossos partners. A verdade é inseparável da fé, como a fé o é da verdade. ${ }^{96}$

O ator deve atuar para o seu partner, influenciá-lo, fazê-lo crer em seus sentimentos e em sua comunicação. O partner é o juiz, o termômetro de sua atuação, e se ele conseguir fazê-lo sentir a verdade dos sentimentos e da comunicação, terá alcançado o objetivo da criação.

Na arte da vivência se estabelece a interação viva entre os jogadores, pois a fé e a verdade estão na ação autêntica, que consiste na busca do vínculo com os partners, procurando influenciá-los e encontrando-se, por sua vez, sob a influência dos mesmos. Esse processo de interação, no aqui e no agora, exige do ator disponibilidade, flexibilidade mental, controle sobre si mesmo, atenção e observação aguda. K. Stanislávski indica o caminho para encontrar a fé e a verdade: no domínio do corpo, nos objetivos e ações, os quais são mais acessíveis, visíveis, perceptíveis e se subordinam à consciência, despertando assim os sentimentos. A fé e a verdade na ação física correta, lógica e coerente são consideradas o melhor estímulo para o sentimento, que é de índole subconsciente, sendo que o caminho que a psicotécnica do ator encontra para despertálo é pela via indireta, pela via consciente.

\footnotetext{
${ }^{96}$ STANISLÁVSKI, K. Sobránie sotchinénii v 8 tomakh, 1954-1961. Rabota aktiora nad soboi. Rabota nad soboi $v$ tvórtcheskom protsésse perejivânia (O trabalho do ator sobre si mesmo. O trabalho sobre si mesmo no processo da criação da vivência). Tomo 2, Moscou: Iskusstvo, 1954, p.168.
} 
A liberdade do ator em cena advém da sua crença na verdade das ações psicofísicas, de sua lógica e coerência. O ator cria, a partir de pequenas ações físicas, uma partitura de ações, espécie de linha, e, através de um árduo trabalho de repetição para dominá-las e fixá-las, realiza e concretiza um caminho em completa relação com os objetivos, com as circunstâncias dadas e com os "se", que levam à verdade autêntica em cena, na qual se pode crer. Para que o trabalho sobre as ações físicas, de forma lógica e coerente, resulte eficaz deve ser "levado até o limite, quando naturalmente se cria o estado chamado 'eu sou', isto é, eu existo, vivo em cena, tenho o direito de estar aqui". 97

O ator, independente do gênero da obra em que atua, deve esforçar-se para executar corretamente as ações criadas por ele, nas circunstâncias dadas pelo autor, de forma gradual, lógica, coerente, captando sucessivamente cada verdade e acreditando nelas, para poder chegar gradualmente ao mais importante momento dramático. Ele tem que saber por que e para que faz tudo o que realiza em cena, as circunstâncias dadas, os “se”, as ações físicas, os objetivos, a fim de criar a vida do papel e com ela a "vida do corpo humano".

A partitura de ações físicas criadas de forma lógica e coerente mantém a atenção do ator na esfera da cena e o orienta numa linha estável do papel, despertando assim a fé no autêntico e a verdade do que faz em cena. O ator, em cena, é levado a perceber a verdade do corpo e do espírito através da linha das ações físicas, pois ela cria uma interação entre ambos, "entre a ação e o sentimento, graças a isso o exterior ajuda o interior e o interior evoca o exterior". ${ }^{98}$ Por meio da ação física o ator pode expressar toda a complexidade da lógica da conduta psicofísica da personagem.

\section{Ações com objetos imaginários e a verdade cênica}

A ação física com o objeto imaginário, além de ser uma técnica psicofísica eficaz para o treino de todos os elementos do sistema, sobretudo a atenção, a imaginação, a lógica e coerência, é também fundamental para o ator criar a verdade cênica. Ela obriga a atenção a se fixar no objeto inexistente e o ator começa a agir. A

\footnotetext{
${ }^{97}$ STANISLÁVSKI, K. Sobránie sotchinénii v 8 tomakh, 1954-1961. Rabota aktiora nad soboi. Rabota nad soboi $v$ tvórtcheskom protsésse voplochtchênia (O trabalho do ator sobre si mesmo. O trabalho sobre si mesmo no processo da encarnação). Tomo 3, Moscou: Iskusstvo, 1955, p. 419.

98 STANISLÁVSKI, K. Sobránie sotchinénii v 8 tomakh, 1954-1961. Rabota aktiora nad soboi. Rabota nad soboi $v$ tvórtcheskom protsésse perejivânia (O trabalho do ator sobre si mesmo. O trabalho sobre si mesmo no processo da criação da vivência). Tomo 2, Moscou: Iskusstvo, 1954, p.179.
} 
ação com o objeto imaginário ajuda o ator a compreender a lógica e coerência das ações, pois, ao estudar cada parte da ação em separado, ele toma consciência dessas partes que constituem as grandes ações físicas. Também ajuda a encontrar a verdade através da lógica e da continuidade das ações, pois estas estabelecem a “ordem, $a$ harmonia, o sentido e ajudam a evocar a ação autêntica, frutífera e dirigida a um fim”. 99 Para ser lógico e coerente nas ações, é necessário obedecer ao processo de início, meio e fim da ação.

K. Stanislávski ${ }^{100}$ diz que, na vida, o que cuida da lógica das ações mecânicas é o subconsciente, a atenção afinada e o controle instintivo. Em cena, o ator deve substituir o mecânico, o automático da vida pelo controle consciente, lógico e contínuo de cada momento da ação física. Para alcançar a organicidade na ação, e, com isso, a verdade e a fé, todos os planos da natureza humana do ator, que são contemplados pelo domínio dos elementos da ação, devem trabalhar de um modo lógico, coerente e em harmonia. Citamos Adriana Dal Forno ${ }^{101}$ sobre a obtenção dessa autenticidade na ação:

A organicidade na ação se constitui pela concomitância do pensamento e do movimento, reconstituindo um processo que, ao longo da vida, é suplantado pelo hábito e pela mecanicidade, que se colocam como obstáculos para a sua realização. ${ }^{102}$

As ações físicas sem objeto, ou seja, com o objeto imaginário, se constituem numa técnica consciente que desenvolve a atenção, a imaginação e influencia os sentimentos. O trabalho sobre pequenas ações com objetos imaginários faz o ator recuperar a consciência da atenção, do controle e da lógica mecânica da ação, fazendo-o lembrar e compreender o sentido e o nexo das pequenas partes da grande ação, o caminho lógico e o seu desenvolvimento. O ator ao lembrar de cada etapa, de forma lógica, coerente e ordenada, de todas as ações integrantes da grande ação, cria a verdade e a crença naquilo que está fazendo. As ações com objetos imaginários levam o ator a

\footnotetext{
${ }^{99}$ STANISLÁVSKI, K. Sobránie sotchinénii v 8 tomakh, 1954-1961. Rabota aktiora nad soboi. Rabota nad soboi $v$ tvórtcheskom protsésse perejivânia (O trabalho do ator sobre si mesmo. O trabalho sobre si mesmo no processo da criação da vivência). Tomo 2, Moscou: Iskusstvo, 1954, p.182.

${ }^{100}$ Ibidem, p.182

${ }^{101}$ Adriana Dal Forno, atriz e diretora teatral, graduada na UFSM. Professora do Departamento de Artes Cênicas da UFSM.

102 DAL FORNO, A. "A organicidade do ator" - Dissertação de mestrado, Universidade Estadual de Campinas, Instituto de Artes, Campinas, 2002, p.39.
} 
ter o controle e a consciência de cada pequeno ato auxiliar de sua ação, e isso o faz atuar em cena de uma forma autêntica, produtiva e conseqüente. As ações com objetos imaginários, com a sua infindável repetição de forma lógica e coerente, tornam-se mecânicas e se constituem na técnica fundamental do ator, pois ajudam a conseguir o processo vivo da criação em cena. Quando o ator passa a utilizar os objetos reais em cena, já de posse dessa psicotécnica e com domínio de um vasto arsenal de ações, elabora cada ação física sem esforço, de forma natural e com precisão absoluta, dentro de novas circunstâncias dadas. Tudo isso tem que ser feito com lógica e coerência, para não destruir a verdade, pois sem verdade não há fé e não há vivência do artista nem do espectador.

O ator, ao realizar em cena uma ação lógica e coerente, depurada de todo o supérfluo, leva o espectador “a perceber o 'mecanismo' da ação que inconscientemente conhecemos na vida”. ${ }^{103} \mathrm{~K}$. Stanislávski via nesse oferecimento ao público da lógica e coerência de cada ação, realizada com precisão, em todos os detalhes, e perfeição pelo ator, uma possibilidade de identificação pelo reconhecimento de algo que ele já não tem consciência de como se faz. Brecht queria, através da habilidade e domínio técnico, que conduzem ao reconhecimento do como se faz, uma forma de estranhamento. São duas visões sobre o mesmo efeito estético:

Tudo o que o ator produz em matéria de gesto, verso, etc., deve ser algo acabado e levar o selo do ensaiado e concluído. Deve produzir uma sensação de coisa simples e fácil, que equivale a sensação de dificuldade superada. Ademais deve permitir que o público aprecie o que ele está colocando de arte, seu domínio do técnico. Está mostrando ao espectador, de maneira mais acabada, como a seu entender se cumpre, ou como foi cumprido na realidade, um determinado processo. Não lhe oculta o que esteve estudando intensamente - da mesma forma que o acrobata não oculta seu treinamento - e sublinha que esta é a declaração do ator, sua opinião, sua versão do processo. ${ }^{104}$

Com a ação sem objeto se criam ainda outras condições, que é a instalação obrigatória da atividade de todos os elementos da natureza orgânica do ator, que envolvem o corpo, a mente, a vontade-sentimento, pois há a exigência de fixar a

${ }^{103}$ STANISLÁVSKI, K. Sobránie sotchinénii v 8 tomakh, 1954-1961. Rabota aktiora nad soboi. Rabota nad soboi $v$ tvórtcheskom protsésse perejivânia (O trabalho do ator sobre si mesmo. O trabalho sobre si mesmo no processo da criação da vivência). Tomo 2, Moscou: Iskusstvo, 1954, p.186.

104 JIMENEZ, S.; CEBALLOS, E. (org.) Técnicas y teorias de la dirección escénica. México: Editorial: Gaceta, 1988, p. 332. 
atenção na segmentação das partes que compõem cada célula das pequenas ações, para poder realizar a totalidade das partes que formam o todo da grande ação. A linha ininterrupta das ações de maneira lógica e coerente faz com que o ator necessariamente lembre cada etapa das pequenas ações que compõem a grande ação. Assim é levado de forma natural à verdade e desta à fé, obtendo assim a mais autêntica vivência. A ação sem objetos obriga o ator a penetrar de forma atenta e profunda na natureza das ações físicas, estudá-las e dominá-las a tal ponto, que se tornam próprias, orgânicas. Esse ato intenso de adentrar na essência da ação física envolve todo o processo físico e orgânico do ator para a realização da ação, gerando a verdade e a fé.

Após um período prolongado de repetição das ações sem objeto, em que o ator se torna capaz de identificar e realizar todos os seus diversos momentos, a natureza corporal do ator passará a agir por si mesma, como respondendo a uma necessidade natural e orgânica, constituindo-se numa segunda natureza. $\mathrm{O}$ ator tem "que amar cada uma das pequenas ações, partes integrantes da grande ação, como o músico ama cada nota da melodia que interpreta”. 105

\section{Relação}

Na vida, o ser humano sempre possui um objeto de atenção. Isso significa que está em constante contato com algum objeto, sendo essa uma lei da natureza humana. A comunicação com o objeto animado ou inanimado surge da relação que se estabelece entre sujeito e objeto, que se dá através de imagens, pensamentos, sentimentos que despertam dentro do sujeito num determinado momento. Em cena, a fim de que esse processo de relação se realize, são necessárias a percepção e a absorção do objeto, para que possa haver contato e, com isso, se instale a comunhão, a entrega e a recepção entre sujeito e objeto. $\mathrm{O}$ ator, em cena, para conseguir entrar em relação, deve voltar totalmente o seu interesse para o objeto de atenção, tornando disponível todo o seu aparato sensorial de ver, ouvir, perceber tudo o que ocorre ao redor, para poder estabelecer a comunhão de dar e receber algo do objeto de atenção. K. Stanislávski não se cansa de repetir: “Os olhos são o espelho da alma. O olhar vazio é o reflexo de uma alma vazia”. ${ }^{106}$

\footnotetext{
${ }^{105}$ STANISLÁVSKI, K. Sobránie sotchinénii v 8 tomakh, 1954-1961. Rabota aktiora nad soboi. Rabota nad soboi $v$ tvórtcheskom protsésse perejivânia (O trabalho do ator sobre si mesmo. O trabalho sobre si mesmo no processo da criação da vivência). Tomo 2, Moscou: Iskusstvo, 1954, p.188.

${ }^{106}$ Ibidem, p.251.
} 
O ator precisa reunir em si um vasto material de criação, com profundo conteúdo espiritual análogo à "vida do espírito humano" do papel, para poder compartilhar o que acumulou em seu interior com os partners em cena. O processo de comunicação em cena deve seguir a mesma lei ininterrupta da linha de ação do papel que deve ser potencializada pela relação que se estabelece entre as personagens e indiretamente com o espectador. $\mathrm{O}$ ator, ao manter a constante "comunicação de seus sentimentos, idéias $e$ ações análogos ao da sua personagem”"107, consegue manter o domínio sobre a atenção do público.

K. Stanislávski considera que o processo de comunicação mútua com o partner é mais fácil de ser dominado. A comunicação pode ser estabelecida com todas as partes do corpo. No entanto, o que deve ser buscado no ser humano é, sobretudo, o seu mundo interior, e, nesse contato com o outro, todos os sentidos devem estar alertas como tentáculos, para captar, compreender e sentir o estado interior do outro. O ator deve estar sempre presente em cena, não destruir a continuidade da comunicação mútua, pois esta exige a entrega e recepção dos sentimentos que se processam pelos olhares e todos os órgãos do aparato psicofísico e pela expressão de idéias, através do pensamento, no ato de escutar, nos silêncios, gestos e atitudes. Na comunicação, o ator deve se esforçar para que suas idéias cheguem à consciência e aos sentimentos do partner e por sua vez, deve captar as idéias do interlocutor já conhecidas, sempre de forma renovada. "Os processos de percepções mútuas ininterruptas, de entrega de idéias e sentimentos devem ser realizados em cada criação que se repete”. ${ }^{108}$

Para poder alcançar essa constante renovação orgânica da criação, há a exigência de muita atenção, técnica e disciplina artística. O processo de comunicação externa, visível, necessita de todo o aparato corporal e sensitivo afinado e sob controle absoluto, para que o ator possa colocar o seu instrumento ativo e receptivo em interação com o objeto. Aqui K. Stanislávski aplica a máxima: “Se os olhos são o espelho da alma, os dedos são os olhos do corpo". ${ }^{109}$ Através da energia visível nos movimentos dos dedos, o mestre media os impulsos internos da ação que envolvia todo o aparato psicofísico do ator e que lhe conferia organicidade.

\footnotetext{
${ }^{107}$ STANISLÁVSKI, K. Sobránie sotchinénii v 8 tomakh, 1954-1961. Rabota aktiora nad soboi. Rabota nad soboi $v$ tvórtcheskom protsésse perejivânia (O trabalho do ator sobre si mesmo. O trabalho sobre si mesmo no processo da criação da vivência). Tomo 2, Moscou: Iskusstvo, 1954, p.253.

108 Ibidem, p.257.

${ }^{109}$ Ibidem, p.265.
} 
Outra forma de comunicação de que K. Stanislávski se ocupou é a que se realiza com um objeto imaginário, inexistente. O objeto inexistente exige do ator uma atitude interior ante o mesmo e para isso deve colocar no lugar do objeto inexistente o seu mágico "se" e procurar responder profundamente o que faria se, no espaço vazio que existe diante dele, estivesse o objeto imaginado. Dá como exemplo o fantasma em Hamlet. $^{110}$ Outro tipo de comunicação é realizado pela via da ação concreta do ator, entendida como a interação do sujeito (ator) com o objeto imaginário, que se dá principalmente no monólogo, em que o ator tem que estabelecer uma relação com aquilo que fala, com as imagens mentais referentes. Esse tipo de comunicação com o objeto imaginário expressa pela comunicação de imagens deve estar presente o tempo todo no ator, e ela se estabelece não só como subtexto da fala, mas nas pausas e silêncios.

Todos os tipos de comunicação exigem profunda atenção na qualidade interior do objeto visado e a presença ativa do ator com o verdadeiro desejo de transmitir e receber emoções vivas, humanas. Essa troca de sentimentos próprios, palpitantes, que resultam da ação concreta, é o que K. Stanislávski reconhece como teatro das vivências. O princípio ativo do processo de comunicação não é só o que se dá pelos movimentos externos, visíveis, sendo também consideradas ativas as ações da comunicação interior.

K. Stanislávski considerava a forma de comunicação interna, invisível e espiritual muito importante. Para o desenvolvimento desse tipo de comunicação, adotou uma psicotécnica chamada de irradiação, que consiste na emissão e recepção de raios. Explica que a terminologia utilizada é um jargão, pois os caminhos invisíveis da comunicação são estudados com as próprias sensações do ator. Ele a define assim:

Uma espécie de comunicação invisível, comunicação recíproca que cria a sensação de uma corrente de vontade que brota das entranhas do ser como se fluísse através dos olhos, através das pontas dos dedos, através dos poros da pele. ${ }^{111}$

As chamadas irradiações são passíveis de ser mais perceptíveis, definidas e evidentes em momentos de fortes emoções, estados de êxtase ou exaltação de sentimentos, tanto para o receptor quanto para o emissor. Esse recurso técnico foi considerado por K. Stanislávski uma forma de comunicação pura, “de uma alma para

${ }^{110}$ STANISLÁVSKI, K. Sobránie sotchinénii v 8 tomakh, 1954-1961. Rabota aktiora nad soboi. Rabota nad soboi $v$ tvórtcheskom protsésse perejivânia (O trabalho do ator sobre si mesmo. O trabalho sobre si mesmo no processo da criação da vivência). Tomo 2, Moscou: Iskusstvo, 1954, p.257.

${ }^{111}$ Ibidem, p.267. 
outra, dos olhos nos olhos". ${ }^{112}$ Foi usado por ele nos últimos anos, vinculado à ação física, onde predominava a ação aguda do olhar, com a total participação do corpo, desde a ponta dos pés, em estado interno intenso e quase em imobilidade.

O ator deve conhecer, a partir de sua experiência pessoal, a força dos raios invisíveis da irradiação. Por um ato de vontade tem que buscá-los dentro de si durante a comunicação e fazer com que fluam de si, mas precisa acumular material criativo para poder transmitir essa corrente de raios. Esse procedimento só é possível se o ator estiver totalmente disponível e livre de tensões supérfluas, porém firme, estável, sem dispersão de energia, pois a comunicação através da irradiação é um processo delicado que não se realiza através do esforço. Com o domínio dessa psicotécnica, a qual exige muito treino, o ator aprende não só a expressar as idéias com as palavras e viver sua essência interior, mas também a perscrutar o outro. Nesse processo de comunicação invisível transcorre um intercâmbio recíproco de percepção, absorção e emissão de idéias e sentimentos que cria a concatenação interior entre os comunicadores.

Na recepção de raios acontece o processo inverso da emissão, há a assimilação dos sentimentos e desejos interiores do outro que fluem de seus olhos, de seu corpo e que envolve o receptor com sua corrente. K. Stanislávski ${ }^{113}$ esclarece que o hipnotismo parte desse mesmo princípio da irradiação. Esse procedimento possibilita estabelecer o nexo interno na comunicação entre os atores, dirigir e fortalecer a atenção sobre o objeto essencialmente estável. Ele salienta a importância de o ator desenvolver essa qualidade, pois ele necessita de uma grande atividade interior e exterior. Diz que é preciso possuir "garras" nos olhos, nos ouvidos, em todos os órgãos sensoriais, porque esse processo de comunicação "exige do ator uma força contínua para que possa lutar pela liberdade, pela idéia e pela existência” e exige “paixões ardentes, alegrias intensas". 114

Para o ator poder viver esse processo organicamente tem que conhecer as leis que regem esses recursos de comunicação, adaptar-se a elas e estudá-las por meio da prática constante até se tornarem uma necessidade orgânica. A irradiação é mais um elemento que enriquece a técnica necessária para a presença e comunicação do ator em cena.

\footnotetext{
112 Ibidem, p.268.

113 STANISLÁVSKI, K. Sobránie sotchinénii v 8 tomakh, 1954-1961. Rabota aktiora nad soboi. Rabota nad soboi $v$ tvórtcheskom protsésse perejivânia (O trabalho do ator sobre si mesmo. O trabalho sobre si mesmo no processo da criação da vivência). Tomo 2, Moscou: Iskusstvo, 1954, p.269.

${ }^{114}$ Ibidem, p.273.
} 


\section{Adaptação}

K. Stanislávski considera que a adaptação é um dos elementos mais valiosos da comunicação, pois o ser humano o tempo todo necessita adaptar-se não só às pessoas com as quais tem contato, mas a si mesmo, ao próprio estado de ânimo do momento e às novas condições e circunstâncias que se apresentam a cada instante de forma inusitada, exigindo do sujeito a capacidade de adaptações coerentes e ajustes que lhe são próprios.

O significado da palavra adaptação no trabalho do ator dentro do "sistema” passa a designar "tanto os meios internos como os artifícios externos com os quais as pessoas se ajustam umas às outras na relação e que ajudam a influenciar sobre o objeto". ${ }^{115}$ A adaptação, além de ajudar a despertar a atenção sobre aquilo com que se quer entrar em contato, seja objeto, seja pessoa, também transmite o invisível, o interno, que não é expresso em palavras, se fazendo ainda necessária para ocultar os sentimentos e a verdadeira ação interior. Ela é indispensável para que a comunicação se realize e as palavras se tornem vivas, plenas de significado, e os sentimentos possam ser revelados. A adaptação, em determinados casos, é uma espécie de ardil, uma estratégia, como também pode ser uma "ilustração visível de sentimentos e pensamentos internos". ${ }^{116}$ Para K. Stanislávski, o êxito na comunicação em cena advém da qualidade da adaptação, de como o ator se ajusta às condições, às circunstâncias dadas, ou seja, da forma que ele encontra, no aqui e no agora, dentro da situação em que atua, para alcançar o objetivo que se propõe. As adaptações são originadas nas mais diversas fontes e valores e a qualidade das mesmas depende de cada artista em particular, pertence a ele somente.

As possibilidades de adaptação são infinitas, dependem da perspicácia do ator, de sua agilidade mental, temperamento, imaginação, individualidade artística e, sobretudo, de sua disposição e capacidade para o jogo. No processo de comunicação, em cena, o ator tem que ser capaz de incutir e exercer o domínio sobre a mente, os sentimentos, a atenção e a imaginação do partner, comover sua alma e, para isso, deve possuir a capacidade de encontrar no dado momento adaptações convincentes. A fim de

115 STANISLÁVSKI, K. Sobránie sotchinénii v 8 tomakh, 1954-1961. Rabota aktiora nad soboi. Rabota nad soboi $v$ tvórtcheskom protsésse perejivânia (O trabalho do ator sobre si mesmo. O trabalho sobre si mesmo no processo da criação da vivência). Tomo 2, Moscou: Iskusstvo, 1954, p.281.

${ }^{116}$ Ibidem, p.281. 
conseguir uma eficaz adaptação, interna e externa, o ator precisa da ajuda de elementos visíveis e invisíveis e, para isso, tem que utilizar todo o seu aparato corporal, os órgãos sensoriais, os movimentos, a emissão e recepção de raios. As adaptações, para poderem transmitir força, precisam ser variadas, terem clareza, agudeza, serem originais, autênticas, audaciosas e inesperadas. O ator em cena necessita de ajustes constantes, que requerem uma infinidade de adaptações pois, além da comunicação ser contínua, ele tem que saber se adaptar constantemente as circunstâncias dadas, ao tempo, ao espaço, aos objetos e a cada pessoa em particular.

K. Stanislávski ${ }^{117}$ qualifica as adaptações em conscientes e subconscientes, sendo que estas são espontâneas, involuntárias, próprias da ingenuidade infantil. As conscientes são geradas voluntariamente e por um ato de reflexão. Em cena, as adaptações espontâneas surgem inesperadamente e impressionam pela sua audácia e força orgânica, visto que são geradas da profunda natureza artística do ator, de sua inspiração criativa.

As adaptações conscientes que o ator retirou e absorveu da vida exigem muito trabalho para poderem ser incorporadas à sua natureza artística, ou seja, para serem transformadas em psicotécnica e virarem semiconscientes, orgânicas. O ator pode tornar essas adaptações convincentes com a aquisição de uma elaborada psicotécnica, ou seja, com o domínio dos elementos poderá encontrar ajustes eficazes em qualquer situação e com o acréscimo de novas circunstâncias dadas. A adaptação exige do ator a capacidade de jogo, que saiba usar os mais variados recursos e ajustes para conseguir o que quer e influir sobre o partner. A busca da diversidade no processo de comunicação deve estar sempre relacionada às exigências da obra, ligada ao objeto de atenção e ao objetivo final, não sendo usada como um fim em si mesmo, para mostrar virtuose.

A principal tarefa do ator, no ato de comunicação em cena, é ajustar-se ao partner, através de ações claras, exatas, lógicas e coerentes. A forma como essas ações são realizadas depende da habilidade artística do ator e de sua capacidade de apresentar adaptações com contrastes agudos e elementos inesperados, as quais devem ser sempre verdadeiras e humanas. Para poder expressar todos os matizes das adaptações em cena, que precisam ser sempre renovadas, o ator deve ter alta exigência psicotécnica, que o obrigue a uma disciplina interna e externa, a fim de poder obter flexibilidade,

${ }^{117}$ STANISLÁVSKI, K. Sobránie sotchinénii v 8 tomakh, 1954-1961. Rabota aktiora nad soboi. Rabota nad soboi $v$ tvórtcheskom protsésse perejivânia (O trabalho do ator sobre si mesmo. O trabalho sobre si mesmo no processo da criação da vivência). Tomo 2, Moscou: Iskusstvo, 1954, p. 285. 
expressividade, delicadeza, domínio e controle do aparato físico e vocal e de todos os meios expressivos. Cruciani fala da alta exigência de K. Stanislávski na técnica da improvisação exigida na realização da ação, sempre renovada em cada momento da apresentação:

O ator improvisa porque aprendeu a representar segmentando, dissecando, depois reconstruindo a ação interna e externa do homem (é o método dos grandes romancistas russos, Tolstoi e Dostoiévski especialmente, que é comparado com a "ciência" de Stanislávski). Stanislávski decompõe/separa/fragmenta o drama nas suas ações $e$ as ações nas suas motivações, para dar ao ator a possibilidade de não atuar "em geral", mas de atuar com precisão e coerência uma sucessão de processos, por meio de exercícios e de improvisações; [...]; a execução e o peso do detalhe são a primeira definição que a prática da improvisação requer na contradição entre precisão e espontaneidade. [...] improvisar é uma palavra que oscila entre criatividade (o trabalho para expressar só aquilo que não se conhece) e habilidade (possuir tanta técnica para poder eleger-ser livre). ${ }^{118}$

Para manter o processo vivo orgânico em cena, sempre com novas adaptações, dentro de uma partitura de ações já determinada, há a exigência constante, por parte do ator, de buscar novas 'iscas', que desencadeiem, estimulem e renovem a criação sem se desviarem de seu objetivo cênico e da precisão da ação. K. Stanislávski solicitava aos seus alunos-atores que estivessem o tempo todo capacitados e disponíveis para entrar no jogo cênico, reagindo a qualquer dado inesperado de forma imediata e espontânea.

\section{Liberdade muscular}

K. Stanislávski constatou que os defeitos físicos que na vida são imperceptíveis se tornam evidentes em cena, potencializados e multiplicados, pois estão sob o olhar atento do espectador, que assume o caráter de uma lupa, tornando-se a cena semelhante ao diafragma de uma câmara fotográfica. Também percebeu, durante o desenvolvimento dos elementos da psicotécnica do ator, as dificuldades do artista em poder expressar o conteúdo interno sem a ajuda de uma técnica externa que viabilizasse a concretização física da vivência. Após relatar uma experiência desastrosa ocorrida pelo emprego de esforço exagerado em cena, decide mudar a ordem da investigação técnica dos elementos internos da ação cênica e dar início ao estudo na esfera do treino corporal para a liberação dos músculos. Considera que a tensão e o esforço físico em cena são ${ }_{118}$ CRUCIANI, F. Registi Pedagoghi e Comunitá teatrale nel Novecento. Roma: E\&A editori associati, 1995,
pp. $94-95$ 
causados pela violação das leis da natureza e paralisam todo o trabalho ativo do ator interferindo em sua vida psíquica, o que se reflete no processo orgânico da ação e na expressão dos sentimentos. Os sintomas da tensão são defeitos que influem sobre o estado geral do ator e a tensão muscular deforma o artista e o impede de atuar, afetando todo o seu aparato psicofísico: o corpo, a voz, os olhos e a respiração. “Enquanto existir tensão física não se pode falar de verdade cênica, de sensações sutis, coerentes, nem de uma vida espiritual normal do papel".119

Essa comprovação levou K. Stanislávski a estabelecer, em seu processo pedagógico, um treino psicofísico que ajudasse o ator a liberar as contrações supérfluas antes de iniciar qualquer trabalho criativo. Era necessária a aquisição de um hábito que conduzisse a uma luta permanente para o desenvolvimento em si mesmo de observação e controle que possibilitassem a elevação da consciência corporal e, com isso, a criação de uma segunda natureza. É proposta a constante relaxação muscular tanto na vida quanto em cena. Essa habilidade é conquistada com exercícios e adestramento sistemáticos para que se torne inconsciente no artista, levando-o a um estado natural. O domínio do controle físico e a ordenação dos músculos tornam-se condição intrínseca do processo criativo para liberar o corpo, impingindo-lhe agilidade na realização da ação, e alterar o estado de ânimo do ator, tornando-o mais ativo e produtivo.

K. Stanislávski, além de ter determinado um treino físico diário, adotou, nessa primeira etapa prática do estudo do elemento liberdade muscular, um programa pedagógico que consistia de exercícios de sensibilização, percepção, equilíbrio, força, resistência, agilidade, destreza e consciência do fluxo da energia interna do movimento. Esse processo era guiado de tal forma que contemplava o desenvolvimento e aperfeiçoamento da vontade, da imaginação, da atenção, da memória, de habilidades cênicas especiais e, sobretudo, visando à realização concreta de uma ação orgânica plasticamente expressiva, dirigida a um fim.

Os princípios da escultura guiaram o desenvolvimento de sua prática nessa etapa na relaxação dos músculos e das tensões necessárias para poder manter uma postura. Para esse fim, propunha "estudar as leis que mantêm o equilíbrio do corpo humano e através da própria experiência aprender a determinar a posição do centro

\footnotetext{
${ }^{119}$ STANISLÁVSKI, K. Sobránie sotchinénii v 8 tomakh, 1954-1961. Rabota aktiora nad soboi. Rabota nad soboi $v$ tvórtcheskom protsésse perejivânia (O trabalho do ator sobre si mesmo. O trabalho sobre si mesmo no processo da criação da vivência). Tomo 2, Moscou: Iskusstvo, 1954, p.133.
} 
de gravidade em cada uma das posturas". ${ }^{120} \mathrm{O}$ ator deve adquirir aptidão para fixar instantaneamente o centro de gravidade nas posturas e manter-se firme. Com o estudo das leis da gravidade, o ator pode vencer qualquer adversário, pois aprende a detectar os pontos vulneráveis, para, sem esforço, fazê-lo perder o equilíbrio.

Esse processo requer atenção aguda, controle, rápida orientação, distinção das sensações físicas e ajustes precisos e firmes. O ator, através do estudo e observação de si mesmo, deve compreender e aprender a encontrar a posição do centro de gravidade, que condiciona a estabilidade. Esses experimentos desenvolvidos sistematicamente levam à consciência do grau de desenvolvimento que se pode "conseguir em relação à mobilidade, à agilidade, à capacidade de adaptação do próprio corpo, no qual os músculos realizam somente o trabalho que lhes indica um sentido bem desenvolvido do equilíbrio". ${ }^{121}$

No desenvolvimento prático desse estudo sobre o equilíbrio, no qual trabalhou as posturas esculturais, K. Stanislávski agrega outros complementos essenciais aos exercícios e exige que:

cada postura não só esteja sujeita ao controle próprio, liberada mecanicamente de toda a tensão, mas que se baseie em alguma idéia imaginária, as circunstâncias dadas e o 'se'. A partir desse momento ela deixa de ser uma pose, mas recebe um objetivo ativo $e$ se converte em ação. ${ }^{122}$

K. Stanislávski insiste que, em cena, todos os movimentos, gestos, atitudes e posições devem ser justificadas, isto é transformadas em ações, precisam de um fundamento e têm de estar a serviço de uma essência interior. Diz que a ação que possui um objetivo concreto, com base em alguma circunstância, leva o corpo agir de forma correta, ou seja, todos os músculos tomam sua verdadeira posição e trabalham corretamente. Na cena, em cada posição do corpo, devem existir três momentos: tensão, relaxação e justificação. ${ }^{123}$ Afirma que um objetivo interessante, fundamentado nas circunstâncias, faz a natureza trabalhar sem obstáculos e leva a realizar uma ação

\footnotetext{
${ }^{120}$ Ibidem, p.140.

${ }^{121}$ STANISLÁVSKI, K. Sobránie sotchinénii v 8 tomakh, 1954-1961. Rabota aktiora nad soboi. Rabota nad soboi $v$ tvórtcheskom protsésse perejivânia (O trabalho do ator sobre si mesmo. O trabalho sobre si mesmo no processo da criação da vivência). Tomo 2, Moscou: Iskusstvo, 1954, p.140.

${ }^{122}$ Ibidem, p.140.

${ }^{123}$ Ibidem, p.141.
} 
verdadeira. Somente a natureza, “em total medida pode dirigir nossos músculos, relaxálos ou tensioná-los corretamente”. ${ }^{124}$

Observa que a tensão necessária para manter determinada posição requer domínio e equilíbrio, sendo que o controle é considerado o inspetor dos músculos, e os ajustes sobre as partes do corpo em movimento devem ser claros como as notas de um instrumento, pois necessitam de precisão e fluência para que soem harmonicamente.

Sem esse requisito, os movimentos que acompanham a um papel não serão adequados e sua execução será, por força, obscura e carente de arte. [...] Quanto mais delicado o sentimento tanto mais precisão e plasticidade requer sua expressão física. ${ }^{125}$

Por essas exigências observamos que K. Stanislávski buscava o ideal de um corpo inteligente, artístico, que obedecesse às ordens do pensamento, da imaginação e tornassem o invisível visível.

“Quem me ensina melhor do que o meu gato?”. ${ }^{126}$ K. Stanislávski indaga sobre a plasticidade do movimento e a sua correlação com a energia que circula internamente no mesmo, e encontra no gato, objeto de sua pesquisa corporal, o exemplo sobre a expressividade e o emprego das tensões. Diz que:

[...] tal harmonia dos movimentos e tal desenvolvimento corporal, como os dos animais, são inacessíveis para o ser homem. Não existe técnica que consiga tamanha perfeição no que tange ao domínio dos músculos. Somente uma natureza inconscientemente apta pode alcançar tal virtuosismo, facilidade, precisão, desenvoltura dos movimentos, poses, e tal plasticidade. ${ }^{127}$

A partir da sua observação, experimenta centenas de posturas e infinidades de adaptações que envolvem todo o aparato corporal interno e externo, respiração, ritmos, variações infindáveis. Tal qual o gato, tenta passar da total quietude para o mais rápido e surpreendente movimento. O gato gasta sua energia com economia, sabe distribuí-la passando da imobilidade para a mobilidade; não perde forças, pois nele as tensões supérfluas são inexistentes. Ele acumula as forças, para dirigi-las, num único impulso, para o centro motor que necessita no momento. Disso resulta suas ações, tão precisas,

\footnotetext{
124 Ibidem, p.143.

125 STANISLÁVSKI, K. Sobránie sotchinénii v 8 tomakh, 1954-1961. Rabota aktiora nad soboi. Rabota nad soboi $v$ tvórtcheskom protsésse perejivânia (O trabalho do ator sobre si mesmo. O trabalho sobre si mesmo no processo da criação da vivência). Tomo 2, Moscou: Iskusstvo, 1954, p.154.

${ }^{126}$ Ibidem, p.140.

${ }^{127}$ Ibidem, p.146.
} 
determinadas e poderosas. A mobilidade e a liberdade dos músculos dos felinos criam uma plasticidade excepcional.

A observação e a mímesis dos animais passam a ser estudo obrigatório, desenvolvido nos programas das “escolas-estúdios”. A mímesis deve ser entendida não como cópia do animal, uma imitação, mas a incorporação do ritmo interno, que constitui a essência de determinado animal. $\mathrm{O}$ ator necessita entender e perceber em si mesmo o mecanismo do corpo do animal, as articulações e plasticidade e, sobretudo, a sua característica interior, as nuances de seu estado anímico, as defesas e ataques.

Através da observação do gato, de suas diferentes e estranhas posturas, K. Stanislávski considera essencial para o ator entender a “psicologia” que leva o animal a adotar determinada posição, a sua natureza orgânica, compreender o seu motor, o que o faz agir desta ou daquela forma.

A apreensão do motor interno da personagem é um requisito necessário para o ator no processo orgânico da criação, na transformação do ator-personagem em personagem-ator, pois, sem a sua captação, se torna impossível a concretização da imagem do papel, ou seja, sua metamorfose. K. Stanislávski declara ter usado o andar do "tigre” em seu papel de Otelo. O ator, para poder expressar sentimentos delicados em personagens complexos, como Hamlet e Otelo, precisa de um corpo flexível, sem tensão supérflua, para sentir-se livre e ter vida própria em cena. ${ }^{128}$

É nesse elemento do "sistema”, liberdade muscular, que K. Stanislávski lança as bases dos princípios teóricos e práticos da cultura corporal que vão reger a pedagogia da área: Fundamentos do movimento cênico, da escola soviético/russa. Todas as práticas corporais estão subordinadas a essa área, com suas disciplinas específicas: cultura física para o desenvolvimento geral do corpo, ginástica, dança, acrobacia, esgrima cênica, quedas, punhal e luta cênica, biomecânica, box, estilos que envolvem diferentes épocas, ginástica sueca, deslocamento cênico e domínio espacial, coordenação simples e complexa do movimento com a palavra, études e improvisações envolvendo as técnicas corporais adquiridas, plasticidade e expressividade do movimento, educação rítmica, tempo-ritmo da ação física e todas as demais técnicas psicofísicas que são incorporadas à esfera do aparato motor. É a produção e aquisição, através de uma prática constante, de um conhecimento consciente da direção do movimento do corpo, na participação e

\footnotetext{
${ }^{128}$ STANISLÁVSKI, K. Sobránie sotchinénii v 8 tomakh, 1954-1961. Rabota aktiora nad soboi. Rabota nad soboi $v$ tvórtcheskom protsésse perejivânia (O trabalho do ator sobre si mesmo. O trabalho sobre si mesmo no processo da criação da vivência). Tomo 2, Moscou: Iskusstvo, 1954, p.147.
} 
complementação de uma ação psicofísica que deve ser sempre autêntica, fecunda, produtiva e ter um propósito.

O desenvolvimento teórico-prático do "sistema”, no que tange ao domínio da cultura do movimento, foi enriquecido pela inclusão de inúmeras técnicas, todas elas a serviço da tarefa prática do ator na aquisição de habilidades e aperfeiçoamento pessoal, para poder concretizar psicofisicamente a vida cênica do espírito humano através da concretização da personagem. Entendida esta, sobretudo, pela sua corporeidade física e psíquica, já que, para alcançar a organicidade, ambas devem formar uma totalidade.

O desenvolvimento e aperfeiçoamento do aparato físico buscam atingir centros motores pouco utilizados, sensibilizar cadeias musculares internas e experimentar sensações desconhecidas, gerando outras possibilidades expressivas. ${ }^{129}$ São focalizados no desenvolvimento e aperfeiçoamento do aparato motor o sistema ósseo ligado ao muscular e o sistema nervoso do ator. O sistema muscular garante a sua ação recíproca com o trabalho interno dos órgãos, a respiração e a circulação sanguínea.

No elemento Desenvolvimento da Expressão Corporal ${ }^{130}$, K. Stanislávski dá continuidade ao programa já em andamento da liberdade muscular. Trabalha, sobretudo, com problemas ligados à organização corporal, à plasticidade, à expressividade e à energia do movimento. Exige que todos os exercícios contemplem a individualidade do ator e devem seguir corretamente o equilíbrio e as proporções específicas de cada corpo em particular. O objetivo aqui é especificar teoricamente e verificar na prática os benefícios de cada técnica e, através do seu domínio, tornar o corpo mais dinâmico, flexível, sensível e expressivo para concretizar fisicamente o invisível.

Marinis $^{131}$ (1949- ) destaca, entre os diretores-pedagogos do Novecento teatrale, no que tange ao trabalho do corpo, a importância de K. Stanislávski, dizendo que:

sempre assinalou a atividade da segmentação, na conduta do alunoator e do ator já formado, em todas os níveis do aprendizado e em todas as fases do processo criativo: seja no trabalho sobre si mesmo, como para chegar a adquirir o considerado 'movimento plástico', isto é, fluído, ininterrupto, sustentado pela 'sensação interior'; seja durante o trabalho sobre a parte, como mediante a

\footnotetext{
${ }^{129}$ STANISLÁVSKI, K. Sobránie sotchinénii v 8 tomakh, 1954-1961. Rabota aktiora nad soboi. Rabota nad soboi $v$ tvórtcheskom protsésse voplochtchênia (O trabalho do ator sobre si mesmo. O trabalho sobre si mesmo no processo da encarnação). Tomo 3, Moscou: Iskusstvo, 1955, p.33.

${ }^{130}$ Ibidem, p.31.

131 Marco de Marinis, um dos mais importantes teóricos teatrais contemporâneos, é professor da Universidade de Bologna e autor de inúmeras obras sobre teoría e prática do teatro do siglo XX.
} 
segmentação progressiva de cada cena e das ações, que são consideradas segundo as suas metas, ou seus objetivos, correspondentes. ${ }^{132}$

\section{Tempo-ritmo}

Onde há vida há também ação; onde há ação há também movimento; onde há movimento há também tempo; onde há tempo há também ritmo. ${ }^{133}$

K. Stanislávski começou seus experimentos sobre o tempo-ritmo com o Estúdio de Ópera Bolshoi de Moscou (1918-1922) junto a alunos-cantores e atores do TAM. Atribuiu-lhe uma importância fundamental, pois considerou que o elemento vinha a contribuir de forma cabal para a arte do ator. Deu ênfase sobretudo à ligação existente entre respiração, atenção e ritmo, como também sublinhou a ajuda da música para criar condições favoráveis à inspiração.

É antológica a experiência que realizou junto aos atores-cantores com uma dezena de metrônomos, aparelho que determina a exata duração do tempo, produzindo os mais variados ritmos, experimentando diferentes atmosferas, estados de ânimo e situações. Contagiava os atores com invenções e jogos, desafiando-os a entrarem nas situações que propunha. Mas foi em seus últimos anos de vida, trabalhando no Estúdio de Ópera e Arte Dramática com jovens cantores e atores, que conseguiu realmente verificar o estreito vínculo do Método das Ações Físicas com o tempo-ritmo. Considerou essa descoberta excepcional para a correlação intrínseca entre tempo-ritmo interno e externo, ou seja, da ação física para o sentimento e vice versa. Destacamos o testemunho de Maria Knébel sobre sua experiência com o mestre neste último período:

Ao trabalhar posteriormente no Estúdio, sob as ordens de Konstantin Serguiêievitch, na qualidade de pedagoga, fiquei surpreendida pelo enorme significado que ele dava ao trabalho sobre o tempo-ritmo e quão ampla e plenamente era trabalhada por ele esta seção da psicotécnica cênica. ${ }^{134}$

Os escritos de K. Stanislávski sobre tempo-ritmo são o somatório das experiências práticas realizadas nos diversos estúdios em que trabalhou sobre esse

\footnotetext{
${ }^{132}$ MARINIS, M. de. In Cerca dell'attore: um balancio del Novecento teatrale. Roma: Bulzoni Editore, 2000, pp.207-208.

${ }^{133}$ STANISLÁVSKI, K. Sobránie sotchinénii v 8 tomakh, 1954-1961. Rabota aktiora nad soboi. Rabota nad soboi $v$ tvórtcheskom protsésse voplochtchênia (O trabalho do ator sobre si mesmo. O trabalho sobre si mesmo no processo da encarnação). Tomo 3, Moscou: Iskusstvo, 1955, p.152.

${ }^{134}$ KNÉBEL, M. O. La Palabra en la Creación Actoral. Madrid: Editorial Fundamentos, 2000, p.183.
} 
elemento. Ele abriu um potente caminho para a eficácia e precisão na arte do ator nessa esfera, sendo que seus seguidores procuraram avançar nas investigações práticas e teóricas do tempo-ritmo, no que tange às correlações entre o físico, o emocional e o mental na arte do ator.

K. Stanislávski esclarece que o elemento tempo-ritmo é um acréscimo muito importante aos estudos práticos, dentro do processo de criação, e que deveria ter sido tratado há mais tempo, mas justifica a ordem em que se encontra dentro do "sistema": “É muito mais fácil e importante falar de forma concreta sobre o tempo-ritmo interno simultaneamente ao externo, isto é, no momento em que ele surge visível nos movimentos físicos [...] que pode ser visto com os olhos". ${ }^{135}$

Apesar de K. Stanislávski entender que era necessário, primeiro, experimentar com o corpo físico para depois captar interiormente o significado e a influência do tempo e ritmo em cena, e alertar da pouca utilidade das definições para a prática do ator, pensamos ser oportuno citar a definição dos termos tempo, ritmo e medida, conforme ele o fez:

[...] tempo é a rapidez com que se alternam períodos iguais, de uma medida qualquer, que são tomados como unidades, condicionalmente aceitas. Ritmo é a relação quantitativa de períodos efetivos (de movimento e som) para a duração, condicionalmente aceitos, como unidades num tempo e medida determinada. Medida é a repetição (pressupõe-se repetida) da soma de partes iguais, condicionalmente aceitas, que se estabelecem como unidades assinaladas pela acentuação de uma delas (duração do movimento e do som). ${ }^{136}$

Essa terminologia só começa a fazer sentido para o ator com o domínio da prática, a qual dá a dimensão das infinitas possibilidades das variações do tempo e ritmo e dos seus efeitos sobre o seu estado criativo geral. Tanto as ações quanto as palavras, por transcorrerem no tempo, devem acontecer dentro de um tempo-ritmo variado, sendo que as ações preenchem o tempo com movimentos rápidos e lentos e pausas, enquanto na linguagem são os sons das mais diversas durações, intercalados por pausas, que preenchem o tempo. "O tempo é rapidez ou lentidão. O tempo encurta ou prolonga a

135 STANISLÁVSKI, K. Sobránie sotchinénii v 8 tomakh, 1954-1961. Rabota aktiora nad soboi. Rabota nad soboi $v$ tvórtcheskom protsésse voplochtchênia (O trabalho do ator sobre si mesmo. O trabalho sobre si mesmo no processo da encarnação). Tomo 3, Moscou: Iskusstvo, 1955, p.140.

${ }^{136}$ Ibidem, pp.140-141. 
ação, acelera ou retarda a linguagem ". ${ }^{137}$ O tempo-ritmo está presente na imaginação, no pensamento, na comunicação, nos sentimentos.

As pesquisas de K. Stanislávski nesse campo se dirigiram, sobretudo, ao estabelecimento de uma psicotécnica que elevasse a arte do ator a uma precisão absoluta da ação psicofísica e da linguagem, correspondendo a uma partitura musical. Com o domínio desse recurso, que se encontra estreitamente vinculado à respiração e à atenção, todos os outros elementos da arte do ator, quer físicos, quer emocionais e espirituais, seriam desencadeados, pois o tempo-ritmo constitui-se num meio direto e imediato para estimular as forças motrizes da vida psíquica: a mente, a vontade e o sentimento. $\mathrm{O}$ caminho para encontrar o tempo-ritmo correto de uma ação se dá através da repetição, até que se estabeleça a sua precisão absoluta e, assim, a autenticidade e a verdade da ação e, como conseqüência, a fusão harmônica da ação física com a psíquica, gerando, no ator, um estado cênico prazeroso. Há a exigência para a ação e para a linguagem dos procedimentos da dança e da música, pois nelas as coincidências rítmicas são rigorosamente regulares e precisas e podem ser trabalhadas e ordenadas previamente, ou seja, podem ser fixadas através da repetição.

A infindável criatividade de K. Stanislávski, na proposição de exercícios para produzir os mais variados tempos e ritmos inseridos num acontecimento involucrado por diferentes circunstâncias dadas, tinha por objetivo não só o domínio do temporitmo da ação e da linguagem mas, sobretudo, criar, no aqui e no agora, o grande espectro de estados anímicos e das paixões humanas necessárias para o papel. "Cada paixão humana, cada estado e cada experiência tem seu tempo e ritmo". ${ }^{138}$ A força do ritmo atua de forma direta e imediata sobre o estado físico e psíquico que influencia o domínio dos músculos e se expressa externamente em todo o aparato físico. O mestre, tomado de um entusiasmo juvenil e contagiante em conseqüência do valioso descobrimento sobre uma verdade já sabida, mas freqüentemente esquecida, sentencia que:

a correta medida das sílabas, palavras e toda a linguagem, dos movimentos e ações, seu ritmo preciso, possuem grande significado para uma vivência verdadeira, mas adverte sobre as duas faces do tempo-ritmo: Se o tempo-ritmo for corretamente tomado, o

\footnotetext{
${ }^{137}$ Ibidem, p.143.

138 STANISLÁVSKI, K. Sobránie sotchinénii v 8 tomakh, 1954-1961. Rabota aktiora nad soboi. Rabota nad soboi $v$ tvórtcheskom protsésse voplochtchênia (O trabalho do ator sobre si mesmo. O trabalho sobre si mesmo no processo da encarnação). Tomo 3, Moscou: Iskusstvo, 1955, p.152.
} 
sentimento e a vivência corretos se criam por si só. Mas se for incorreto, então, da mesma forma, naqueles lugares do papel que os sentimentos e a vivência não forem corretos, só podem ser corrigidos se o tempo-ritmo for modificado. ${ }^{139}$

É através da ação física, lógica e coerente, da ação da palavra e da comunicação a serviço de um objetivo que o ator consegue transmitir o tempo-ritmo e as coincidências rítmicas precisas em cena. Na música, são as notas que transmitem o ritmo, enquanto que, para os atores, diz K. Stanislávski ${ }^{140}$, as ações segmentadas em movimentos de diferentes medidas e durações e a linguagem formada por letras, sílabas e palavras, curtas ou longas, acentuadas ou não, são as que marcam o ritmo.

O mestre conduzia seus ensinamentos pela via técnica, do externo para o interno, até que o ator dominasse os diferentes ritmos e os gravasse em sua memória, onde se estabeleciam como um metrônomo interno que o ator carregava dentro de si, resultando que as ações e palavras do papel fossem realizadas com a contagem interior, mental, do metrônomo próprio.

Para que o ator consiga uma gama diversificada de ritmos na partitura das ações físicas e das ações vocais e possa atuar de forma produtiva e com um fim, esse processo exige, num segundo momento, a criação de visões internas, invenções da imaginação decorrentes das circunstâncias dadas. Num papel como o de Hamlet, para poder expressar o conflito, há a necessidade de coexistirem vários ritmos diferentes para provocarem a luta interior de princípios opostos. “[...] diante de estados complexos, com linhas e correntes internas contraditórias não é possível conseguir dar conta com um único tempo-ritmo. É necessária a combinação de vários”. 141

K. Stanislávski ${ }^{142}$ propunha ao ator elaborar os ritmos em separado até dominálos e só depois fundi-los. Exigia que o ator detectasse e fixasse os momentos de ênfase e que encontrasse em seu organismo "o metrônomo imaginário”, ou seja, que tivesse a consciência do lugar, no corpo, onde ocorria o processo das pulsações do tempo-ritmo evidenciadas pelo movimento. Depois da constatação de que essas pulsações internas são sempre manifestas de maneira física, alternando a mobilidade com a imobilidade

\footnotetext{
139 Ibidem, p.147.

140 STANISLÁVSKI, K. Sobránie sotchinénii v 8 tomakh, 1954-1961. Rabota aktiora nad soboi. Rabota nad soboi $v$ tvórtcheskom protsésse voplochtchênia (O trabalho do ator sobre si mesmo. O trabalho sobre si mesmo no processo da encarnação). Tomo 3, Moscou: Iskusstvo, 1955, p.153.

${ }^{141}$ Ibidem, p.163.

${ }^{142}$ Ibidem, p.158.
} 
como forma de conhecimento consciente, o ator deve justificá-las com as circunstâncias dadas, pois são elas que servem de apoio para a velocidade e a medida corretas.

Ruffini, em seu texto sobre o elemento tempo-ritmo do "sistema" de K. Stanislávski, afirma que se trata de um estudo sobre a música, sendo esta uma arte que compreende poesia e dança, conforme a acepção da antiga Grécia, a qual o mestre percebeu que levaria à "grande música”, ou seja, à ação interior, a de um sentimento verdadeiro:

Para suscitar sentimentos verdadeiros, será necessário falar e agir em forma de poesia e de dança, respectivamente. O objetivo do ator de Stanislávski permanece sempre o mesmo: dar expressão sensível aos sentimentos verdadeiros, para isso serve a revivência. Aquilo que muda, agora, é a via para despertá-los: a ação sobre os sentimentos não é mais a via psicotécnica, mas o tempo-ritmo justo. Ou seja, através da poesia e da dança: compreendidas na música. ${ }^{143}$

Segundo José A. Sánchez ${ }^{144}$ (1963- ), a necessidade de utilização de formas equivalentes à música, sejam sonoras ou imagéticas, na arte teatral, surge da desconfiança com a palavra. Isso se dá, sobretudo, nas produções simbolistas, em que Edward Gordon Craig (1872-1966) pensava o drama como "uma construção mediante a ação, a linha, a cor e o ritmo”. Assim a música se converte em "guia das demais artes”, e o conceito de partitura passa a ser sinônimo de 'dramaturgia', sendo que K. Stanislávski é considerado o primeiro a utilizar o termo partitura tanto para a arte do ator quanto para a composição cênica: "estas partituras respondem a diversos conceitos da 'música cênica'”. ${ }^{145}$

Enumeramos a seguir as descobertas valiosas e revolucionárias a que $\mathrm{K}$. Stanislávski chegou e, mais tarde, sua discípula direta Maria Knébel, sobre o temporitmo para a finalidade da criação, as quais foram incorporadas à psicotécnica do ator, à criação do papel e à composição do espetáculo, segundo A. K. Kokórin ${ }^{146}$ : o temporitmo ajuda a chegar ao momento dramático mais agudo e a realizar as valorizações e as passagens de um acontecimento a outro; determina as circunstâncias dadas e o modo de atuação, que se encontram intimamente relacionados entre si, sendo que as

\footnotetext{
${ }^{143}$ RUFFINI, F. Stanislavskij: Dal lavoro dell'attore al lavoro su di sé. Roma: Laterza, 2003, p.74.

${ }^{144}$ José A. Sánchez Martínez, Doutor em Filosofia e Ciências da Educação, pela Universidade de Murcia, com o tema "Beltolt Brecht la disolución y las formas". Professor do Departamento de História da Arte na Faculdade de Belas Artes de Cuenca, Universidade de Castilla-La Mancha, Espanha.

${ }^{145}$ SÁNCHEZ, J.A. Dramaturgias de la imagen. Múrcia/Cuenca: Gráfica Cuencas, 1992/94, p.29.

${ }^{146}$ KOKÓRIN, A. K. Vam priviet ot Stanislávskovo (Saudações de Stanislávski para vocês). Moscou: A.

K. Kokórin, 2001, pp.187-188.
} 
circunstâncias dadas evocam o tempo-ritmo, e este faz pensar nas circunstâncias dadas; cria o sentimento e a vivência de forma orgânica; desperta a memória emotiva, atua sobre os sentimentos e estimula a si mesmo, gerando o estímulo interno; faz reviver as sensações de uma experiência passada, desperta as lembranças e recordações visuais; qualquer situação da vida possui seu tempo-ritmo correspondente; o tempo-ritmo da vida do ser humano muda constantemente e está na dependência da mudança das circunstâncias dadas, da sua influência sobre o ser humano; o tempo-ritmo da obra é o tempo-ritmo da linha transversal de ação e do subtexto; o tempo-ritmo encontra-se em dependência direta da correta valorização das circunstâncias dadas, dos acontecimentos da obra e do superobjetivo do autor; quanto mais complexas as circunstâncias da obra, do papel, mais difícil e complexo é o tempo-ritmo; possui ligação orgânica com o caráter da personagem, com seu subtexto, com o segundo plano, com o monólogo interno; a apreensão correta do tempo-ritmo ajuda o ator a evocar o sentimento verdadeiro, mantendo-o e contribuindo de forma mais plena para a sua expressão.

K. Stanislávski comprovou, na prática, outras relações do tempo-ritmo com o sentimento e observou que: para que o tempo-ritmo exerça a sua força nas lembranças e nos sentimentos, é necessário que o ator crie imagens, representações mentais das visualizações correspondentes às circunstâncias dadas, e que tenha ações e objetivos definidos; o ator quando está imerso numa determinada situação com as circunstâncias dadas deve pensar no que ocorre e de que modo ocorre, para, então, obter a representação do tempo-ritmo, pois ele tem que corresponder àquilo que está ocorrendo; o tempo-ritmo é necessário não por si só, mas ligado às circunstâncias dadas, que criam o estado de ânimo relativo a sua própria essência interior; o tempo-ritmo encerra não somente as qualidades externas, que influem diretamente sobre a natureza do ator, mas também o conteúdo interior que nutre o sentimento; a atmosfera criada pelo temporitmo sugere novas circunstâncias dadas e novos sentimentos, estados de ânimo que sugerem novas situações, tudo dependendo do aumento ou retardo do ritmo.

O tempo-ritmo é o alargamento e o coroamento do objetivo do "sistema”, que busca a fusão harmônica total da ação física com a psíquica, na qual o ator cria por si só a música internamente, a partir do corpo que vive e da alma que passa a crer. Há nesse processo a necessidade do estabelecimento da segunda natureza, ou seja, da plena organicidade na arte do ator. 


\section{AS ÚLTIMAS EXPERIÊNCIAS DE K. STANISLÁVSKI NO ESTÚDIO DE ÓPERA DRAMÁTICA}

O fundamental tema de nosso Estúdio: "estudar-estudar". O teatro ou ergue o ser humano ou o corrompe. Aquele que pensa que ele já não tem mais nada a estudar, que já alcançou tudo, este não tem lugar no Estúdio. ${ }^{147}$

Essa apresentação é uma idéia-síntese da introdução de I. N. Vinogradskaia aos estenogramas do Estúdio de Ópera Dramática contidos na obra Stanislávski Ensaiando, registros realizados no referido Estúdio. Neles destaca-se, sobretudo, a nova metodologia de K. Stanislávski, ou seja, o método das ações físicas na construção do papel desenvolvido na prática com os estudantes. Esse foi o último laboratório experimental em que K. Stanislávski realizou suas pesquisas na esfera das ações físicas de 1935 a 1938. As aulas foram ministradas na pequena cena do TAM, na rua Gorki, e em outros espaços, até mesmo na casa de K. Stanislávski, situada na travessa Leontiévski. Esse espaço, desde 1953, recebeu o nome de Estúdio de Ópera Dramática de K. Stanislávski. Após a morte de K. Stanislávski quem assumiu o Estúdio, ao longo de nove anos, foi M. N. Kedrov (1893-1972), um dos estudantes prediletos de K. Stanislávski.

Os atores do TAM que foram assistentes-pedagogos de K. Stanislávski no estúdio estudaram com ele o "sistema”, pois, além de terem participado de diferentes estúdios, também se preparavam para ensinar. “O Estúdio de Ópera foi uma instituição superior de estudos teatrais. Com alta qualificação do corpo de professores. Com alta e qualificada formação pedagógica da atividade teatral e musical”. ${ }^{148}$

No estúdio eram ensinadas todas as disciplinas práticas e teóricas que faziam parte do programa pedagógico criado por K. Stanislávski, que estabelecia a orientação das investigações empreendidas por ele e tinha como objetivo a educação de um novo tipo de ator - “cidadão, indivíduo e artista de alta categoria, com livre domínio das últimas conquistas obtidas com o sistema”. ${ }^{149}$

Esses professores-assistentes ensinavam études para a arte do ator, rítmica, plasticidade do movimento cênico, dança, acrobacia, palavra cênica, colocação da voz,

\footnotetext{
147 STANISLÁVSKI, K. aput VINOGRADSKAIA, I. N. (org.) Stanislávski Repetíruet (Stanislávski ensaiando). Moscou: MKHT, 2000, p.441.

${ }^{148}$ VINOGRADSKAIA, I. N. (org.) Stanislávski Repetíruet (Stanislávski ensaiando). Moscou: MKHT, 2000, p.431.

${ }^{149}$ Ibidem, p.431.
} 
dicção e correção de defeitos vocais, canto, domínio da música com pianista e compositor, história do teatro, literatura e pintura, entre outras. Todas as disciplinas referentes à especificidade teatral eram orientadas por K. Stanislávski, que acompanhava também as orientações da parte musical, em que aproveitava todas as oportunidades para destacar a importância da cultura musical, do tempo-ritmo da ação e da ação da palavra cênica.

A presença da atividade dramática e de ópera num único estúdio não foi casual, pois para Stanislávski isso possui significado fundamental e profundo sentido. Stanislávski acumulou imensa experiência com o trabalho no teatro dramático e no operístico, e considerou que ambos os tipos de arte podem e devem enriquecer um ao outro. ${ }^{150}$

O mestre considerava que o cantor, além de dominar a música e o canto, devia dominar a arte do ator. Por sua vez, o ator dramático não poderia se desenvolver totalmente sem os fundamentos da cultura musical, sem a assimilação da prática e da disciplina musical.

A ética e a disciplina ocuparam lugar importante nas aulas de K. Stanislávski, que considerava ambas como determinantes da qualidade do trabalho no coletivo e da própria estética. Esta encontra-se estreitamente vinculada à posição do artista como pessoa, ao seu super-superobjetivo, à sua capacidade de criar e viver como um único organismo, que é o que possibilita criar a esfera espiritual no trabalho criativo.

Essa exigência levava o artista à necessidade de auto-educação e aperfeiçoamento pessoal numa superação constante de si mesmo, não somente na especificidade teatral, mas no domínio do conhecimento humano, da cultura e da arte em geral. Para conseguir personificar as grandes idéias, o ator deve possuir um nível intelectual elevado, ter a capacidade de reflexão de grandes pensamentos, sentimentos e ter gosto apurado. Para poder realizar uma nova forma artística e criar em cena a vida humana, ajudando, assim, a transformar a vida e as pessoas com a sua arte, o ator tem que se envolver organicamente com a sua época e responder aos problemas da existência humana da vida dessa época.

Para Stanislávski, ética não é somente uma importante parte do método das ações físicas criado, é o seu sustentáculo, a sua alma, o

\footnotetext{
${ }^{150}$ VINOGRADSKAIA, I. N. (org.) Stanislávski Repetíruet (Stanislávski ensaiando). Moscou: MKHT, 2000, p.431.
} 
seu fundamento. $O$ ator distante do princípio ético-moral, propõe Stanislávski, não pode criar pelo método das ações físicas. ${ }^{151}$

K. Stanislávski, nesse período, dedicou muito tempo ao seu teatro de ópera, constituindo-se este em sua maior preocupação, e trabalhou intensamente com os estudantes do estúdio. Dirigiu ensaios e encenou inúmeras óperas, não só clássicas, mas do repertório moderno soviético. Em 1935, no TAM trabalhou com os atores ensaiando Molière, de Bulgákov (1891-1940), e trabalhou com Tartufo, de Molière, em 19371938, aplicando seu último método. Também nesse período deu conferências sobre as suas últimas investigações, escreveu artigos sobre o "sistema”, além de terminar de escrever a segunda parte do livro $O$ trabalho do ator sobre si mesmo.

No estúdio, o próprio mestre se ocupava em iniciar os estudantes no processo criativo e em despertar neles a independência artística através da aplicação de exercícios chamados de “toalete do ator” e dos études realizados por meio da ação física com objetos imaginários. O mestre exigia que o estudante-ator fosse independente na criação dos études, que, ao serem mostrados, passariam por uma minuciosa análise, em que eram apontados todos os seus pontos insuficientes e suficientes. Além da avaliação do trabalho, esclarecia o significado de cada exercício aplicado no processo de ensino do ator. K. Stanislávski também se dedicou, neste período, com muita ênfase, à palavra cênica e às aulas de tempo-ritmo.

A fixação do material de ensaios realizados no Estúdio de Ópera Dramática e dos ensaios nos últimos anos de K. Stanislávski com os atores do TAM possibilita, hoje, dominar e entender os preceitos práticos do seu "sistema”.

Nessa última etapa de seu trabalho, como já é conhecido, não enfoca mais os sentimentos como ponto de partida, pois estes são obtidos como resultado, mudando, dessa forma, o processo de abordagem sobre o papel, não sofrendo mais a fragmentação do texto em pequenas partes. Há o estabelecimento e a exigência da realização de uma linha de ação interna e externa ininterrupta do papel, criada com lógica e coerência absolutas na ação que conduz o processo de comunicação na cena. Todos os elementos do sistema, considerados inseparáveis um do outro, também passaram a fazer parte do processo unitário da criação, e eram trabalhados em situações concretas, nos études na dependência das respectivas circunstâncias dadas e do nível de desenvolvimento em que

\footnotetext{
151 VINOGRADSKAIA, I. N. (org.) Stanislávski Repetíruet (Stanislávski ensaiando). Moscou: MKHT, 2000, p.434.
} 
o ator se encontrava, recebendo maior ou menor significado. "Todos os elementos do sistema estão ligados entre si e ajudam a criar a principal artéria do papel”. ${ }^{152}$

Na concretização do processo de criação, K. Stanislávski não intervinha na esfera da individualidade do ator, mas procurava, através da improvisação, alcançar o fortalecimento da linha da ação interna, sem que houvesse uma preocupação com a mise-en-scène, para só mais tarde chegar aos momentos artísticos desejados. Considerava que o ator tinha que possuir uma firme linha interna, inquebrantável, ligada à linha transversal de ação e ao superobjetivo do papel, do étude ou do espetáculo.

A única linha a que em vocês permanece inabalável é a linha da ação interna [...] diante disso, vocês não devem demorar muito tempo em alguma mise-en-scène, mas somente, como vejo agora, no que estão presos nesse momento, e transmitam-no. [...] Eu propositadamente desnortearei, confundirei a mise-en-scène de vocês para fortalecer a ação interna. ${ }^{153}$

A ação física é o fundamento concreto com o qual o ator dá inicio à criação e através dela é gerada a ação interna, obtendo assim, nesse processo, o comportamento orgânico nas circunstâncias dadas. K. Stanislávski esteve sempre preocupado com a verdadeira ação do ator:

Com que ações vocês podem explicar a elas - as personagens? Correr para alguém ainda não é a expressão de uma ação. Atrair a atenção do partner. Correr não quer dizer chamar a atenção. Eu preciso ver seu trabalho interno, e não o trabalho das suas pernas. ${ }^{154}$

O ator-cantor devia entender que ação o compositor tinha em mente quando escreveu a partitura, para obter a ação física e poder agir a partir da música e só depois dizer o texto, gerando, desta forma, a vida em cena. O processo necessário era, primeiro, a lógica da ação, seguida da música, e, por último, a palavra. A voz correta é conseqüência da linha da ação e da música corretas.

\footnotetext{
${ }^{152}$ VINOGRADSKAIA, I. N. (org.) Stanislávski Repetíruet (Stanislávski ensaiando). Moscou: MKHT, 2000, p.435.

153 STANISLÁVSKI, K. aput VINOGRADSKAIA, I. N. (org.) Stanislávski Repetíruet (Stanislávski ensaiando). Moscou: MKHT, 2000, p.436.

${ }^{154}$ Ibidem, p.437.
} 
K. Stanislávski atribui grande significado, na criação artística, ao estado de espírito geral do ator em cena, ao processo de comunicação, à interação do ator com o partner e com o meio circundante. Dizia que na verdadeira comunicação se dá o “engate”, em que se estabelece uma luta com o partner da qual participam todos os elementos do sistema: atenção, vontade, ação interna e externa, percepção, sentimento da verdade, crença nesse sentimento, etc. Solicitava aos alunos-atores ter "garras”, possuir a capacidade de entrelaçamento com o objeto, pegar algo dele. O elemento da verdadeira comunicação é aquele que assegura o conjunto e a inteireza do futuro espetáculo.

Para poder dominar o verdadeiro processo instantâneo da comunicação cênica, é necessário que o ator leve em conta exatamente o seu estado de hoje e o do partner. O movimento da própria vida, sempre renovado, deve ser incorporado a qualquer atividade criativa, nos exercícios, ensaios e espetáculos.

A fonte da experiência da vida é inesgotável. Se o ator não contar com a natureza orgânica, a capacidade dele chegará a um ou dois espetáculos, e depois, será repetição, clichês, o motor do hábito tagarelar palavras de cor, fazer movimentos musculares costumeiros. $^{155}$

Vinogradskaia reafirma a importância do ator em manter-se conectado com a vida para a sua arte:

Não interromper a ligação do ator-ser humano com a vida; não com a vida em geral, mas com a realidade concreta de hoje, exige evitar especificamente que o ator atue estados anímicos em cena, e procurar criar o estado humano orgânico ligado com a vida real ainda que provocando a invenção imaginativa - essa é a pedra angular do sistema, a qual constitui a sua garantia de estar sempre vivo e atual. Stanislávski nunca identificou a vida cênica com o nosso cotidiano da vida real. Mas o "diapasão da vida”, pela expressão de Stanislávski, deve sempre ser percebido pelo ator, e essa amplitude pode colorir todo o papel de forma nova. ${ }^{156}$

K. Stanislávski impunha altas exigências para a técnica externa do ator, no desenvolvimento e colocação da voz, plasticidade e domínio do corpo. O ator deve não somente possuir sentimentos, sensibilizar-se, mas contagiar os outros com os seus

155 STANISLÁVSKI, K. aput VINOGRADSKAIA, I. N. (org.) Stanislávski Repetíruet (Stanislávski ensaiando). Moscou: MKHT, 2000, p.438.

${ }^{156}$ VINOGRADSKAIA, I. N. (org.) Stanislávski Repetíruet (Stanislávski ensaiando). Moscou: MKHT, 2000, p.438. 
sentimentos, com a sua verdade. Sua ação deve ser convincente e contagiante para o espectador, possuir encanto cênico, o que só é possível se tiver o domínio profundo e sutil de seu aparato. Como diretor-pedagogo, foi muito criterioso e severo com os estudantes, em relação às formas buriladas, e preocupado com a expressão cênica externa:

Qual clássico vocês podem representar, se vocês possuem deficiências nos treinos do aparato físico? Vocês podem ter uma linha interna maravilhosa, mas vocês não podem se apresentar na cena com insuficiências na técnica externa. [...] Esforcem-se para que vosso corpo seja elástico, belo, plástico. ${ }^{157}$

Entendia que as aulas de dança, voz, dicção, rítmica, acrobacia poderiam dar somente fundamentos, direcionar o trabalho do ator, mas o principal treino diário devia ser feito em casa, pela manhã, no momento de descanso, do passeio, antes do sono e em cada minuto livre. Os estudantes, independentemente, devem estudar, exercitar as ações com objetos imaginários, constantemente treinar a sua atenção, o seu aparato físico.

$\mathrm{Na}$ arte das vivências, a qual K. Stanislávski professou, é inconcebível a existência do ator sem o domínio da técnica, sem o sentimento de estilo e forma e sem a capacidade de utilizá-los. K. Stanislávski queria que o ator experimentasse a alegria da total liberdade nos movimentos, sentisse o ritmo, percebesse a sua plasticidade e tivesse o domínio da voz. Exigia que os estudantes dominassem todos os elementos do "sistema” através de um treino constante, com base nas aulas práticas estimuladas pelos professores.

No museu do TAM, existem 48 estenogramas de aulas e palestras de K. Stanislávski no Estúdio de Ópera Dramática. Para a publicação Stanislávski Ensaiando foram escolhidos alguns estenogramas, nos quais encontram-se reflexões e exigências gerais de K. Stanislávski, apresentações aos atores de sua escola para o trabalho sobre os exercícios, études , “toalete do ator”, sobre o coletivo, como também perguntas sobre ética teatral, disciplina, e o debate dos dois primeiros atos de As Três Irmãs e os estenogramas sobre o trabalho de Hamlet:

Os estenogramas não abrangem a representação total sobre aquilo que acontecia nas aulas. Os estenogramas escritos são esquemáticos; por eles, absolutamente, nem sempre é possível

157 STANISLÁVSKI, K. aput VINOGRADSKAIA, I. N. (org.) Stanislávski Repetíruet (Stanislávski ensaiando). Moscou: MKHT, 2000, p.439. 
captarem o sentido dessa ou daquela frase ou parágrafo. Muitos exemplos que Stanislávski trouxe de sua vida pessoal na arte não são decifrados, mas somente referidos. Por isso, para sua publicação os estenogramas foram submetidos à algumas redações, facilitando o entendimento da essência do acontecido.[...] Na realidade, as aulas de Stanislávski sempre foram vivas e festivas, freqüentemente inesperadas para os estudantes. Stanislávski entusiasmava aos alunos e a si mesmo. ${ }^{158}$

Consta nos estenogramas das aulas de K. Stanislávski o trabalho orientado por ele sobre a tragédia Hamlet de Shakespeare. Ele mesmo ocupou-se com a principal imagem cênica, e determinou a linha transversal do papel de Hamlet. O mestre permitiu que a estudante Irina Rozanova, por insistência própria, trabalhasse no papel da personagem principal. Ela distinguia-se pelo seu temperamento forte e elevada emoção. K. Stanislávski ocupou-se muito com a cena do Fantasma, pois entendia que esse era o momento de mudança radical em toda a tragédia.

Nós selecionamos para a presente tradução somente as aulas sobre Hamlet.

\section{Tradução dos estenogramas das aulas-ensaios sobre o papel de Hamlet ${ }^{159}$}

\section{Hamlet - Shakespeare - 21 de abril de 1937}

(pp.455-462)

Konstantin Stanislávski - Então falem, o que vocês conseguiram?

Viakhireva (professor assistente) - O senhor nos deu Hamlet. Eu comecei o trabalho com o que contei aos estudantes: o conteúdo da peça; dividi o segundo ato pelos fatos e fiz com que cada um deles falasse o seu prelúdio a partir do momento da morte do rei. Depois pedi que cada um escrevesse a linha física do papel.

(K.S. solicita que leiam a linha física do papel de Hamlet. Rozanova a lê).

K.S. - Vocês percebem que aqui houve ações inconscientes de Hamlet, as quais vocês misturaram com as conscientes? Mas é necessário ser muito mais simples. Qual é a tarefa de vocês aqui?

Rozanova - Entender o que está acontecendo.

\footnotetext{
${ }^{158}$ VINOGRADSKAIA, I. N. (org.) Stanislávski Repetíruet (Stanislávski ensaiando). Moscou: MKHT, 2000,p.441.

159 Tradução de Nair D’Agostini da obra de VINOGRADSKAIA, I. N. (org.) Stanislávski Repetíruet (Stanislávski ensaiando). Moscou: Ed. MKHT, 2000.
} 
K.S. - Muito bem, eu preciso entender, observar... O que vocês devem fazer para isso nas atuais circunstâncias dadas? Vejam que vocês têm circunstâncias dadas concretas: eu viajei por muito tempo, quando cheguei vi que tudo mudou. O pai havia morrido e a mãe casara-se com outro. Na mãe você encontrou uma outra pessoa - outra mulher - alegre e coquete. O que vocês fariam nesse caso?

Rozanova - Eu perguntaria à mãe sobre a razão de tais mudanças.

K.S. - Muito bem, mas vocês não têm a possibilidade de falar com a mãe, o que fariam neste caso?

Rozanova - Eu seguiria os seus passos e a observaria.

K.S. - Então, escrevam essas ações. Anotem: observar. A palavra "observar” significa uma única ação ou muitas?

Todos - Muitas.

K.S. - Então, dividam esta ação em suas partes integrantes. A arte não pode ser “em geral” - ela é sempre concreta. O que vocês fariam para entender a metamorfose que ocorreu com sua mãe? Eu levo vocês do plano do ator para a real esfera humana de vocês.

Expliquem-me: como cada um de vocês agiria, baseado na sua experiência pessoal, para compreender o que está acontecendo com sua mãe? Fale, o que você deve fazer para responder a essa pergunta? Que processo está acontecendo em sua alma?

Rozanova - Um processo de perplexidade. Eu não entendo o que acontece com a mãe de Hamlet.

K.S. - Não há nenhum Hamlet, somente você! Passe tudo para você. Pode imaginar, por exemplo, que a sua vizinha é a sua mãe?

Rozanova - Posso imaginar minha mãe real?

K.S. - Por favor, que seja a sua verdadeira mãe. Vá pela sua memória emocional. O que você necessita fazer para entender essa situação?

Rozanova - Eu observo a minha mãe para saber o porquê dela se comportar de tal forma.

K.S. - Apenas isso?! Imaginem: você volta, esperando ver a sua mãe de luto e em lágrimas e, de repente, no lugar disso, a encontra alegre e, além disso, casada com um canalha, vil. Para isso escolha em sua vida a pessoa mais desagradável para você e imagine-a ao lado de sua mãe. O que você faria nesse caso?

Rozanova - Eu sentiria ciúmes.

K.S. - Sente-se e sinta ciúmes. Isso é possível? 
Rozanova - Não, não posso.

K.S. - Ciúme é resultado de muitas ações. Por exemplo, Otelo. No resultado de toda a peça fica claro que Otelo tem ciúmes. Que processo acontece em você quando você olha a sua mãe?

(Rozanova está pensando)

Afanasiév - Eu tenho que reavivar a imagem de minha mãe pela memória emocional. Como ela era antes?

(K.S. continua em silencio)

Piatnitskaia - A mãe mudou, ela é totalmente outra, ela se relaciona comigo de forma diferente, eu sinto isso.

K.S. - Vocês todos falam comigo na língua do resultado, mas eu necessito que vocês falem na língua da ação.

Chur - Observo a mãe e vejo que ela mudou. Olho para o rei e os comparo.

K.S. - (Para Rozanova) O que você irá fazer?

Rozanova - Lembrarei de minha mãe. Minha mãe era tão carinhosa! Como ela servia chá para o meu pai, como ela era atenciosa com ele!

K.S. - Correto, isso em você são quadros separados, visualizações separadas. Agora, com base nas memórias emocionais de sua vida faça-me um grande quadro. No grande quadro inclua: a mãe afetuosa, que ama você, ama o marido, imagine-a no dormitório, e de repente... o quadro é totalmente outro: você vê sua mãe casada, e ainda com um miserável! Ela está alegre e contente.

Rozanova - Isso tudo existe em mim de passagem.

K.S. - Isso tudo não deve ser imaginado passageiramente. Você deve imaginar nitidamente toda a vida, desde criança até a morte do pai. De que ela pode se compor? Ela armazena-se de suas próprias lembranças emocionais, de pequenos episódios os quais para você são especialmente caros. Conecte esses fatos e entrelace-os nessa vida. Imaginem, através das visualizações, tudo: até pequenos detalhes, tudo o que é caro a vocês. Mas esse quadro não deve ser passageiro: você deve pormenorizar e aprofundar a vida inteira. Bom seria arranjar aquele livro dourado e com letras de ouro e escrever nele seus papéis. Esse material é que não tem preço. Esse material é para os seus futuros papéis. Vocês devem juntá-lo a vida toda.

A primeira condição artística é a seguinte: assim que eu recebi o papel, por exemplo, Hamlet, doravante Hamlet - já não existe mais separado de mim. Existo eu 
nas circunstâncias dadas de Hamlet. Tudo vocês captem das suas lembranças emocionais.

Rozanova - Mas será que eu necessito imaginar o que eu estudei em Vittenberg?

K.S. - Veja, você estudou! Assim, imagine-se na tal instituição em que você estudou. Mas, pode ser que você tenha uma idéia sobre Vittenberg? Apesar de ser fantástica, criada somente por você e entendida somente por você? Então, junte-a! Se eu ler sua linha, então eu confundo você, por isso eu quero que você pegue tudo de suas lembranças emocionais pessoais. Eu não quero oferecer nada a vocês.

Chur - Vamos imaginar Konstantin Serguiêievitch, que eu realizei todas essas ações, e começo a sobrepor nelas o texto da peça, mas se ele não coincide com as minhas ações?

K.S. - Você sabe a natureza da ação, a sua estrutura. E, se a estudar, você pode fazê-la em todas as circunstâncias dadas e em qualquer ordem. Por exemplo, a verdade e a lógica de se vestir para vocês são conhecidas, vocês se acostumaram com elas. Imaginem que vocês levaram essa ação até o fim, estudaram-na e me falam: “Agora eu vou representar esta ação para o senhor”.

Hoje é feriado, não estou apressado para ir a lugar nenhum, eu levanto e começo a me vestir. O processo de se vestir está sendo estudado há tanto tempo, que vocês se vestem inconscientemente. Assim não atrapalha os pensamentos, que chegam a vocês. Querem ler um livro, leiam. Amanhã vocês não gostariam mais de ler o livro - não o leiam. Pode ser mais pálido, mas de qualquer forma, uma nova ação é mais valiosa do que a de ontem. Adiante, você muda as circunstâncias dadas: "Hoje eu atrasei-me para a escola e por isso me apresso". Eu devo executar todas as ações físicas de me vestir, não suprimir nada, mas agora em cinco minutos.

Na próxima etapa pode ser de incêndio, pânico. Falem abertamente: vocês entendem isso? Falem caso não entendam algo.

Ginzburg - No primeiro ano de estudos nos falaram que o ator, terminando o espetáculo, deve ir para a sua casa e lavar de suas paletas todas as suas adaptações. É necessário saber o que eu fiz, mas absolutamente não é necessário saber como eu fiz: descrevendo as ações físicas, eu descreverei como eu ajo.

K.S. - Para que descrever o como? Vocês descrevam o que vocês vão fazer. Se vocês vão se cuidar, então, assim será - o que eu posso fazer? Não é necessário descrever, como eu farei. Esse como cada vez mudará, ele assumirá forma nova, a forma de hoje. E é bom, se ele puder mudar. 
Chur - Eu entendi que o senhor quer, que possamos, em cada estado de espírito, dividi-lo em ações físicas simples.

K.S. - Se aparecesse tal ator, que com profundidade realizasse o trabalho, imbuído de todos sentimentos humanos, esse seria o ator ideal. No final das contas, a natureza dos sentimentos é a mesma, mas neles, inevitavelmente, deve haver lógica. A lógica dos sentimentos é uma característica de toda obra genial. Indo para o papel, nós encontramos lá os sentimentos, a natureza e as ações físicas que para nós são conhecidas. E aqui nós vemos que a ação física coincide com o texto quase com a mesma coerência de pensamento. Eu procuro o papel em vocês e, para que vocês entendam a lógica de dada pessoa, obrigo vocês a fazerem as ações mais simples.

Assim o que eu farei para entender os atos de minha mãe?

Viakhireva - O mais difícil - agir a partir de si mesmo! Quando os estudantes sentam, eu sinto que eles pensam como se fossem outra coisa, mas não como eles mesmos.

K.S. - Mas, na vida, por acaso é difícil para você agir a partir de sua própria pessoa?

Chur - Mas será que eu faço corretamente? Imaginariamente, de mim sai uma pessoa, como se fosse o meu segundo “eu”, e eu vejo como este homenzinho age. Vejo ele andar, cumprimentar alguém, perguntar sobre algo, mas eu sei também que simultaneamente esse sou eu mesmo.

K.S. - E você copia a si mesmo? Isso é representação pura. Assim fazia Koklen ${ }^{160}$. Koklen contava como ele trabalhava: "Eu vejo a imagem de Tartufo, eu visto nele a roupa de Tartufo e em pensamento escolho para ele a maquiagem. O Tartufo está pronto, eu entro em cena, e o copio”. Mas Koklen foi um homem genial e dominava essa técnica perfeitamente; nós podemos amar e admirar essa técnica, mas acreditar em Koklen não podemos. Vocês aplaudiriam depois do espetáculo, mas, assim que saíssem do teatro esqueceriam Koklen e Tartufo.

Tenham medo disso como do fogo. Isso cria o clichê vulgar. Copiar não é arte. Façam sempre e tudo a partir de seu nome, perguntem a si mesmos sempre: como eu faria hoje, nas circunstâncias dadas, isto e aquilo.

Chur - As ações físicas são adaptação?

\footnotetext{
${ }^{160}$ B. K. Koklen (1841-1909), ator francês. N.T.
} 
K.S. - As ações físicas são ações físicas, mas elas necessitam de adaptações. Por exemplo, nós temos uma ação física - adular; a adaptação para ela deve ser acariciar, pegar pela barba, etc.

Jamais pensem na adaptação, no ajustamento. A adaptação pensada é um truque, um clichê. Na peça Todo esperto tem seu dia de bobo ${ }^{161}$ é muito fácil se enganar. Ela é toda feita nas adaptações. Uma pessoa sempre está sentada, desenhando, outra sempre dá conselhos. O que há de horrível nisso? É importante que as adaptações não se transformem no objetivo.

Ginzburg - Essa é minha tarefa - sou uma figura simpática, ou não?

K.S. - Essa é a sua ação.

Ginzburg - Eu toco na sua mão, acaricio.

K.S. - Essas são suas adaptações e não devem ser fixadas. Esse é o novo método e vocês devem entender.

(Para Rozanova) O que assusta você em Hamlet? Você tem que comparar sua mãe: como ela era antes e como ficou agora. Onde está aqui a ação física? Essa comparação será a ação física, apesar de ser mental. Em nossa arte isso é invenção da imaginação.

Vejam: na visão há ação. Nesta ação interna haverá ação física, porque ela nos dá o impulso - o sinal para ação, mas para nós é importante despertar essa chamada. Se isso for estudado e a ação pensada, nós vamos provocar o truque.

Chur - Eu quero esclarecer: nós estamos fazendo corretamente? Vamos supor que eu vou até os pais de minha noiva para esclarecer se ela vai continuar sendo minha noiva ou não, e me deparo com o escândalo. O que eu tenho que contar? Que eu abro a porta, observo a sala, entro, fecho a porta, viro a cabeça para um e para outro lado?

K.S. - Não, você não deve fixar isso, que você vira a cabeça para um ou para outro lado, mas que, ao defrontar-se com o escândalo, com um obstáculo inesperado, você demonstra que não percebe esse escândalo, isso é o que você deve fixar.

Na vida há ações físicas grosseiras, mas eu não vou incluí-las, sobre elas é necessário falar em separado. Imagine que você arruma o quarto. Diante de quais circunstâncias dadas você não o arrumaria como sempre, todas as ações de limpeza você necessita obrigatoriamente fazer, e elas sempre serão aproximadamente iguais. Pois não é assim?

${ }^{161}$ Peça de A. N. Ostrovski. N.T. 
Piatnitskaia - Se, por exemplo, eu estou limpando uma simples mesa e necessito tirar o pó dela, colocar em ordem as coisas que estão sobre ela, então eu limpo cada objeto. Mas se essa mesa pertencesse à mãe morta, cara para mim pela lembrança, eu a limparia totalmente de outra forma?

K.S. - A ação física será igual a de sempre, você não poderá fazê-lo de outra forma. Você limpa o pó e coloca os objetos no lugar, mas a sua relação com eles será diferente.

Piatnitskaia - Mas como eu posso expressar relação com essa mesa?

K.S. - Realizem ações físicas nas circunstâncias dadas e não pensem sobre quais sentimentos elas devem despertar em vocês. Façam com verdade e lógica, façam assim como vocês as fariam hoje, no estado de ânimo de hoje, contando com todas as complexas casuais do dia de hoje. Lembrem que tudo isso tem uma grande importância. E agindo logicamente no dia de hoje, vocês nem percebem como chegam aos sentimentos corretos.

Pois os sentimentos não podem ser fixados, por isso eu procuro somente aquilo que é possível fixar, e isso será uma ação física.

Ginzburg - Tudo isso é maravilhoso, mas o que exatamente eu necessito descrever nesse livro? Pois um faz uma coisa, e outro faz outra?

K.S. - Lembrem que esse livro é somente para vocês! Se eu pegar esse livro, eu não vou entender nada o que há nele, porque eu tenho o meu próprio livro, conveniente com a minha individualidade. Lembrem o que é mais importante: despertar no ator o impulso para a ação.

(Para os estudantes) Mas vocês devem acumular em si esses sinais e começar a agir somente quando sentem que já não suportam mais. Começam a agir, refletindo sentados sobre as mãos. Vocês podem me pedir que eu dê a vocês a possibilidade de se moverem, mas eu não deixo que se movam porque, eu sei: entre seis de seus movimentos quatro estarão errados.

Se nós deixarmos vocês saírem daqui antes do tempo, vocês cairão no clichê, dando liberdade a seus músculos vocês imediatamente cairão no clichê.

Vocês devem realizar seu papel somente com ações físicas, pelas chamadas em direção a elas. Assim é a vontade do ser humano - como se fossem fios delicados, mas os músculos são cordas pesadas. Por acaso vocês podem com tais fios trincar as cordas (músculos), já treinadas no clichê? Mas se vocês com esses fios delicados entrelaçarem 
a corda, nada será mais forte do que essa corda; e assim vocês já não se assustam com os músculos, vocês os submeteram a si.

Nós vamos segurar vocês aqui em inércia externa até que, como o pinto, com o próprio tamanho quebrem a casca do ovo. Pois isso é sabido: se a casca do ovo com o pinto quebrar antes do tempo, ele morrerá. Mas, quando o pinto alcançar tamanho normal, então com o seu próprio corpo, quebrará a casca.

Martianov - Konstantin Serguiêievitch, o que eu devo anotar? Hoje, por exemplo, a minha tarefa é mostrar-me carinhoso. Para isso, eu coloco a mão no ombro do parceiro, olho-o nos seus olhos, mas pode ser, que amanhã eu vá querer para essa mesma tarefa fazer algo totalmente diferente?

K.S. - É necessário que vocês fixem as suas ações: lisonjear, mostrar-se carinhoso. Porque se mostrar carinhoso pode ser feito de mil maneiras. Enfim, da combinação de todas essas adaptações resulta, então, que vocês acariciaram.

Seria muito bom que cada vez que vocês acariciassem o fizessem de formas diferentes, novas, e não repetindo as antigas, adaptações já decoradas.

Eu já falei que não se deve ir pela adaptação. Acariciar é uma ação, mas as adaptações dessa ação serão de mil maneiras.

Sokolova - Kostia, eles se confundem sobre como descrever, como fixar, quando é necessário fazer tudo toda vez de forma diferente?

K.S. - Vocês devem anotar somente as ações e não devem fixar a adaptação.

Ginzburg - Eu quero ler o que eu escrevi, para ver se está correta a ação do papel. (lê, contando não somente ações, mas algumas adaptações)

K.S. - Não está mal, mas eu escreveria disso somente as ações: "verificar a relação delas consigo mesmo” (aqui pode ir “acariciar”). Segurar-se na rainha como atrás da “autoridade" - a partir disso seguem todas as adaptações, as quais você necessita para isso. Esconder seu sentimento pelo Hamlet.

Guinsburg - Para isso Hamlet deve me olhar de tal maneira, para que eu comece a esconder meus sentimentos por ele.

K.S. - É claro, sempre é necessário orientar-se pelo partner, mas imagine-se em um caso tão infeliz que ele se apresente como um poste, com um rosto que não expressa nada. Você deve deixar de agir? Não. Você olhou para ele e ele não devolveu nada, mas se você tem uma lógica forte, a utilize e não se desligue do papel. Você pela lógica sabe: se Hamlet olhasse para você, você teria que esconder seus sentimentos. Quer dizer, utilizem aqui o mágico “se” e a lógica. 
(Piatnitskaia lê sua linha física do papel de Gertrudes, incluindo nela a situação, sua relação com o papel e as adaptações)

Há aqui muita coisa supérflua, pois a sua principal tarefa é apresentar o marido de forma que o aceitem como rei.

Piatnitskaia - Sim, mas eu mesma devo fazer algo para que o aceitem.

K.S. - O que você fará para isso? Você - Olga Mikhailovna?

Piatnitskaia - Olho para todos. Pode ser, sorrio.

Chur - É necessário chamar a atenção de todos para o rei.

K.S. - (para Piatnitskaia) Vocês me falam de adaptações, mas eu necessito que vocês me falem de ações. Apresentar o marido! Mas isso inclui muitas ações. Para que ele seja bem recebido, talvez você deva acariciar, lisonjear alguém, subornar e tudo isso é formado por muitas ações e adaptações.

Você percebe que rica paleta tem aqui. Realize tudo isso e a vossa tarefa estará cumprida.

Viakhireva - Konstantin Serguiêievitch, que o senhor não exige fixação das adaptações, isso está totalmente compreendido. Mas vamos supor, os estudantes escreveram ações físicas. Enquanto nós agimos, sentados nas mãos, de onde eu, pedagogo, saberei com quais adaptações eles me revelam essas ações físicas?

Será necessário que eles me contem as adaptações, que me falem como eles, neste determinado caso, pretendem agir? Ou eles somente me falam como, num determinado fragmento, eles entendem a cena, e eu devo acreditar em suas palavras e ir adiante?

K.S. - Se você acredita que ele entende, então siga em frente. Eu, em seu lugar, perguntaria o que o estudante faria em tal caso. Em cada ação é necessário olhar.

Skalovskaia - Eu estou trabalhando com a peça Deslealdade e amor $^{162} \mathrm{e}$ gostaria de, no meu material, saber como verificar na prática a linha da ação física de Vurm no ponto em que ele chega ao Muller.

K.S. - Quando o homem chegou à casa onde acontece um bate-boca, um escândalo, o que ele deve fazer? Ele mostrará que não percebeu esse escândalo. Em primeiro lugar, ele olha, quem discute com quem. Em segundo lugar, avalia se pode falar sobre seus interesses, então surge a relação necessária entre determinadas pessoas e surge a lógica da ação.

${ }^{162}$ Peça de F. Schiller (1759-1805). N.T. 
Imagine que você veio para cá, mas aqui há um escândalo. Talvez o escândalo seja tamanho que você nem consegue falar, apenas fechar a porta e sair.

Estudante - Como o senhor falou que há partner cujo rosto não expressa nada. É necessário, assim mesmo, continuar sua linha?

K.S. - Pode acontecer que vocês encontrem na vida real tal excêntrico, o que nada expressa no rosto. Você, nesse caso, mesmo assim levará sua linha. Aqui vos ajuda o mágico "se fosse".

Skalovskaia - Se freqüentemente repetirem-se pequenas ações físicas, acumulam-se os clichês. Às vezes queixam-se os estudantes disso. O que fazer nesses casos?

K.S. - Deixe que façam assim. Como diz Leonid Leonidov ${ }^{163}$. Hoje eu atuei o papel, peguei a esponja e limpei tudo; amanhã devo buscar tudo de novo, já novamente pelo o que acontece no dia de hoje.

Afanasiév - Quer dizer que tudo depende das circunstâncias dadas? Sempre devemos fazer de nova maneira?

K.S. - Se você cada vez contar com as circunstâncias dadas e o partner, então em você, obrigatoriamente, surgirão novas adaptações.

Chur - O que se deve fazer no seguinte caso: eu falo com o professor que aqui faço assim e assado, mas o professor responde-me que isso não é correto, que ele não faria assim. Dessa forma, ele me imporia algum ponto de vista seu.

K.S. - Eu não faria isso! Eu necessito que vocês se revelem no papel, para que encontrem a si mesmos no papel e o papel em si, mas depois, com o tempo, eu colocaria circunstâncias dadas tais que obrigassem vocês a fazer diferente.

Viakhireva - Konstantin Serguiêievitch, o que fazer quando os estudantes imaginam para si ações físicas somente por elas serem novas e não velhas?

K.S. - Isso é ruim. Não é importante que essas ações físicas sejam velhas ou novas, mas elas, cada vez, devem ser justificadas e lógicas.

Piatnistkaia - Mas como fazer em casos em que eu estudo minha tarefa e a mim parece que devo realizá-la de determinada forma, mas quando começo a executá-la ou contá-la, de repente, de modo totalmente inesperado, chegam outras adaptações?

K.S. - Isso é exatamente aquilo que é o necessário.

${ }^{163}$ Leonid Leonidov (1873-1941), ator do TAM e de grande temperamento trágico. N.T. 
Gurko - Em As Três Irmãs eu passo pensando e realizando ações físicas, e isso provoca resposta nos sentimentos.

K.S. - Vocês atuem corretamente. As ações físicas são necessárias somente para obrigar a agir o sentimento e nosso inconsciente. Depois, as adaptações durante a criação deverão vir inconscientemente.

\section{Hamlet - Shakespeare - 13 de maio de 1937}

(pp.462-469)

K.S. - (Para Viakhireva) Você vai dar a aula, e eu vou assistir. Depois falaremos.

(A cena é do encontro de Hamlet com o Fantasma. Rozanova fala sobre a linha de seu papel)

K.S. - Muitas coisas não estão ruins, há coisas muito boas. Vamos analisar. (para Rozanova) Quando você pensa em Hamlet o que fica em seu estado geral? (Rozanova fala de sua linha contínua, acrescentando seus sentimentos, sua fantasia)

Aquilo que eu gostaria é bem mais simples. Você se antecipa na imagem e no sentimento, mas eu necessito tudo muito mais simples. Mostre-me o processo orgânico da espera. Como a pessoa espera alguma coisa? (Rozanova analisa o momento da espera). O que vocês farão?

Rozanova - Escutar.

K.S. - Você vai se orientar. Com o que a pessoa se orienta?

Afanasiev - Olharei.

K.S. - Com os olhos, ouvidos, consciência. E ainda com o quê?

Afanasiev - Com a imaginação.

(Rozanova fala que na imaginação dela passa algumas mães, entre as quais ela não consegue escolher uma para ela. K.S. esclarece que essas mães imaginadas, mas não visualizadas, não são conhecidas dela na vida)

K.S. - Sempre peguem o seu partner (no presente caso, Olia Piatnitskaia) tal qual ele é hoje. Eu necessito de vocês somente isto: vocês voltaram para casa e encontraram sua mãe, não chorando, mas alegre e casada com um canalha. Você quer entender o que está acontecendo com ela. Eu não necessito de mais nada. Aqui eu os interrompo e pergunto: o que significa entender, o que é necessário fazer para isso?

Rozanova - Eu não sei como ela é: meiga ou perversa? 
K.S. - Você fala sobre o papel, mas eu necessito falar sobre a natureza humana. Isso é bem mais fácil, tão simples, como se nada fosse preciso fazer.

Imaginemos que na sala entrou uma pessoa estranha, um estrangeiro de farda. Você quer entender para que ele veio. Ele andou entre as pessoas e foi embora sem dizer uma única palavra. O que você organicamente vai fazer para saber por que esse homem veio.

Rozanova - Eu olho para a mãe, mas ela não me olha, ou olha alegremente, mas não triste. Como eu devo atuar, triste ou alegre?

K.S. - Assim você já entra na esfera do subconsciente. Eu não necessito disso. Você começa a representar o resultado. Hoje a mãe está de tal jeito, e eu devo agir assim, mas amanhã pode ser diferente. Ela está alegre, quer dizer, ela não está arrependida, e então desenvolvo ações em relação a ela. No outro dia Olia Piatnitskaia vai estar triste, ou seja, está difícil para ela, pois sente que fez algo errado. Ela merece piedade, e terei outras adaptações em relação a ela. É necessário sempre estudar como está o partner no momento. Se você atua, uma vez para sempre, uma única linha, não prestando atenção no estado do partner, essa linha não só será não-lógica: ela será estereotipada. O que quer dizer entender ou observar? Essa, pois, é uma verdade banal. Se você realiza alguns papéis pelo processo orgânico, você saberá todos eles. O que significa observar eu sei; o que significa conhecer eu também sei. Com o que então inicia cada processo de entender? Ele começa quando você lança os tentáculos dos seus olhos nos olhos da mãe; você necessita saber por que ela é assim. As pessoas que estão sentadas ao seu redor talvez saibam. Quero sondar os olhos de cada um em seqüência. Todos estão tranqüilos, somente eu não entendo o que está acontecendo. Então tenho que aglutinar os pensamentos e compreender sozinho. Nesse caso pode haver dois tipos de comunicação: ou eu passo a relacionar-me com a mãe imaginária ou posso relacionar-me comigo mesmo (como se minha mente se relacionasse com meu plexo solar).

Rozanova - Hoje eu olho para Olia, e ela está assim, mas amanhã ela será outra.

K.S. - Vejam: isso é valioso. Ajam como é necessário hoje, agora. Ontem ela estava amável, amorosa, mas hoje está coquete. Observem como ela está hoje e não deixem passar nada.

Rozanova - Será que isso me aproxima do papel de Hamlet?

K.S. - Hamlet não existe, somente existo “eu” nas circunstâncias dadas de Hamlet. Se você parar de pensar “como eu faria isso?”, e começar a pensar em como 
Hamlet o faria, isso já seria estranho: não é seu. Isso não será arte, será oficio. Eu necessito que você, exatamente você, decida o que está acontecendo hoje com a mãe, com Olia Piatnitskaia, sua partner. Sim, se você já conjeturou sobre o passado da sua mãe e até pôde comparar como ela está hoje com como ela estava no passado, mas de forma autêntica, humana, isso é tudo de que eu preciso. Mas lembre-se, não pode copiar o passado. Vá sempre pelo novo, pelo autêntico do dia de hoje. Imaginem que hoje o espetáculo transcorre animado, você, então, precisa entender de onde origina-se essa alegria. Você poderá empenhar-se em saber, ter forte vontade de entender no que consiste isso. No próximo espetáculo, todos atuam molemente, algo não funciona, a rainha está indolente, impassível. Você pode atuar como ontem? Não, você deve entender por que ela está indiferente, por que ela está indolente. Em cada espetáculo, você deve procurar a lógica e esforçar-se em entender, no dia de hoje, o que acontece com a mãe. (Fale o que quer dizer entender)

Rozanova - Mas nas nossas aulas, não há nenhum cortejo nem corte; nós sentamos, ao todo, algumas pessoas, não há sala, nem banquete, nem casamento.

K.S. - Você pode fantasiar, em geral, tudo, o casamento e o banquete. Mas, se agora você tem só três pessoas, imagine que os outros se retiraram; o rei não fala com os ministros, mas dita ao secretário aquilo que quer falar. Por acaso, sua ação será outra, por acaso você não sente aversão? Por acaso, você não quer ardentemente entender o que aconteceu com a mãe quando ela olha o novo rei com olhos de apaixonada?

Rozanova - Tudo bem, aqui eles, pelo menos, estão sentados e esperam o que eles deveriam falar, mas nas aulas um escreve suas tarefas, e o outro espera eu terminar de falar.

K.S. - Não vá pela mise-en-scène; esses estudantes, na opinião de vocês, devem sentar aqui, outros, lá; isso não é correto: assim vocês podem cair no clichê. Peguem os partners assim como eles são. Se alguém escreve algo, deixe que escreva, aproveite-se disso. Vocês não podem sentir por todos, deixem que cada um faça o que quer. No fim das contas, se você, individualmente consegue realizar todos os processos orgânicos, então vocês podem representar Hamlet em cinco minutos.

Skalovskaia - Mas essa é uma ação imensa.

K.S. - A minha infelicidade é que eu ainda não encontrei um nome correspondente. Isso até não é ação; eu quero somente que haja os impulsos para a ação. Isso se relaciona mais com o estado cênico interno. 
Skalovskaia - Na prática do meu trabalho eu revelei que tudo deve ser levado para o processo orgânico da relação.

K.S. - Há diferentes tipos de relações. Dê-me esse processo orgânico, assim como ele é. Pois aí está o problema: todos possuem ações orgânicas, até os cães, o réptil marinho, mas o ator na cena não o possui. No final das contas, tudo vem da relação.

Chur - Mas relacionar-se todos podem, mas atuar na cena nem todos podem.

K.S. - Isso porque todas as pessoas na vida podem ser como pessoas normais, mas na cena ser como uma pessoa normal está longe de ser possível a todos. Nós falamos que todos têm a linha orgânica, não a possui somente o ator em cena. Vejam, somente na cena é possível pensar o que quiser, cantar palavras amorosas em público, pressionar a debutante para junto de si, na qual vocês até nem olham. Vocês devem entender que na cena é necessário fazer o mais simples possível ações orgânicas humanas. Simples assim, parece até que não há nada a fazer aqui.

Rozanova - Eu não consigo imaginar o fantasma: se ele é grande ou pequeno. Eu não consigo senti-lo, mas vejam que eu devo sentir medo.

K.S. - Vocês querem saber como vão sentir, e, então, fixar seus sentimentos. Isso é impossível. Essa é a teoria da arte da representação. Essa é uma arte ingrata, muito difícil. Como se poderia dizer: eu necessito sentir? Vejam: pode-se sentir ou não sentir. Qual fantasma vocês não conseguiriam imaginar, de qualquer forma é necessário perguntar a si mesmo: o que eu faria?

Rozanova - Mas como deveria ser: eu fantasio para mim o fantasma, mas nesse mesmo momento entra um estudante?

K.S. - Assim que ele entrar, você fala para si: se ele fosse o fantasma, o que eu faria? $\mathrm{O}$ ator deve, em qualquer momento de sua vida, poder acionar alguma alavanca, a qual conduz tudo para o lado da imaginação. Imaginem que agora será aberta uma parede e estaremos diante de mil espectadores. Digam, isso será arte? Não. Mas imaginem que esta sala é um quarto do navio "Majestik", no qual vamos para a América. E nós continuamos no navio estudando. Veja que isso não será a vida, mas arte. Arte porque, inicia-se a esfera da imaginação.

Rozanova - Agora eu nas aulas imaginarei aquilo que me é insuficiente.

K.S. - Não, não é necessário. Olhem, como se sua imaginação não estivesse em contato com objetos mortos. Eu tive uma atriz muito talentosa que se perdeu nisso. Ainda há um ator, ao qual esse procedimento conduziu ao rompimento. Antes de tudo, 
para você não existe nenhum Hamlet, existe somente você, e o que você faz e como você age hoje, nas circunstâncias dadas.

Ginzburg - Mas imagine, Konstantin Serguiêievitch, que na cena com alguma pessoa eu devo dar-lhe uma bofetada. E, de repente, hoje meu partner se comporta muito molemente e não me dispõe a isso, a dar-lhe uma bofetada. O que eu devo fazer?

K.S. - Mas você não pode explicar para si mesmo o comportamento dele, totalmente indiferente, como desprezo por você? Imagine, como isso pode levá-lo a explodir!

Ginzburg - Sim, mas o senhor mesmo falou: uma vez é necessário atuar de um jeito, outra vez, de outra forma. Mas como fazer para atuar sempre bem?

K.S. - Por acaso existe tal instrumento, que mede o bom e o ruim. Vejam: nesse momento, bom, mas nesse ruim. Nossa infelicidade é que nós, obrigatoriamente, queremos atuar bem; atuem não bem, mas com verdade. $\mathrm{O}$ ator valoriza a sua atuação pela quantidade de risadas no público. Essa avaliação é mais revoltante e uma avaliação trivial. Vocês devem atuar sempre com lógica. Esforcem-se realmente para captar o partner e saber o que vocês fariam naquelas circunstâncias. Depois de cada espetáculo, vocês devem pegar a esponja, como recomenda Leonidov, e lavar todas as adaptações, para que em vocês permaneçam somente as tarefas principais. O ideal seria cada vez atuar no espetáculo em mise-en-scènes diferentes, para que até elas não se tornassem padronizadas. Inabalável é somente a permanência da linha interna do papel. No ano passado houve uma aula em que vocês me mostraram exercícios com ações com objetos imaginários: vocês enfeitaram um arco com as flores e o retrato. Vocês estavam em cinco pessoas, ficaram de costas para o diretor e enfeitaram a parede. Vocês ficaram assim, como nenhum diretor colocaria os atores, mas essa foi uma mise-en-scène verdadeira: alguém se esticava para pregar algo; alguém se inclinava e com interesse observava as pessoas, permanecendo de costas para mim, como bastões na horta. Uma vez, no ensaio de Talentos e admiradores ${ }^{164}$, batalhamos muito tempo numa cena, e em algum momento os artistas começaram se aconselhar uns com os outros, e cercaram completamente a personagem principal e aglutinaram-se ao redor dela, escutando, o que ela falava. Eu prestei atenção nisso, em que maravilhosa mise-en-scène resultou. Vichinevski, muito sensível nesse aspecto, aproximou-se de mim e perguntou: "O senhor viu?..”.

\footnotetext{
${ }^{164}$ Peça de A. N. Ostrovski. N.T.
} 
Eis o sentido da própria vida. Nenhum diretor se arriscaria em tal mise-en-scène, mas, sem premeditação, saiu maravilhosa.

A melhor artista é nossa natureza; aquilo que nos dá o subconsciente é orgânico e maravilhoso. $\mathrm{Na}$ arte da representação, o ator deve fixar todas suas emoções nos músculos, decorar, e essa cópia da vida levar para cena. Esse trabalho é ingrato e infernal. Os papéis criados por Koklen e Sara Bernard ${ }^{165}$, nos primeiros minutos surpreendem pela sua verossimilhança, mas logo você percebe que se trata de imitação. Eles não comovem. Vocês não vão lembrá-los por muito tempo, mas para nós, para o Teatro de Arte, o maior elogio foi quando as pessoas disseram: "vamos hoje às irmãs Prozorovi”. Isso queria dizer assistir a As Três Irmãs no Teatro de Arte. Os espectadores não somente lembravam o espetáculo, mas o vivenciaram junto com os atores.

Rozanova - O que eu devo fazer agora com Hamlet?

K.S. - Faça as mais simples e habituais ações humanas que compõem os processos: entender, seguir, espiar, convencer, etc.

Krugliak - O senhor diga-me, aquilo que hoje eu escrevo realizarei dentro de cinco anos? A mesma coisa?

K.S. - O processo orgânico caracteriza não somente o homem, mas todos os seres vivos existentes. Vocês deverão realizar cada vez o processo orgânico, mas isso não será repetição, e sim a nova arte, porque cada vez vocês terão que observar o partner e olhar como ele está naquele momento; disso surgirá, a nova arte. Isso é o que nós buscamos. Não percam o momento da comunicação.

Quando Marcelo e Horácio vêm a primeira vez a Hamlet, ele ainda não pode interromper seus pensamentos, ele ainda necessita pousar na terra, entender de onde eles vieram, como eles apareceram aqui. Não deixem passar os momentos de relação nova. A tarefa de Horácio, por sua vez, é de observar Hamlet: por que ele está assim, o que há com ele, como dizer a ele o segredo sobre a Sombra do pai. Finalmente falam para Hamlet sobre a Sombra do pai. No primeiro momento você sempre afasta de si algo desagradável. Imagine, que, chega uma pessoa e lhe fala: o mar Cáspio alaga Moscou, aqui ainda está seco, mas já pela Tverkoi não dá para andar. É claro, no início há um momento de desconfiança. Vocês podem tentar comparar algo, confirmar. Quantas ações Marcelo e Horácio necessitam efetuar para que Hamlet acredite neles. Mas no teatro ruim normalmente isso se faz assim: apenas o ator consegue dizer as primeiras

\footnotetext{
${ }^{165}$ Famosos atores franceses B. K. Koklen e Sara Bernard (1844-1923). K. S. os considerava como os mais importantes exemplares de arte da representação.
} 
duas palavras, o seu partner põe as mãos na cabeça, sabendo perfeitamente, o que o outro falará para ele depois.

Krasnuchkina - Nós sabemos como expor tais estados, como a esperança, o ciúme, etc.

K.S. - O ciúme abrange toda uma série complexa de processos orgânicos. Em esperança não existem os mesmos processos orgânicos, pois em alguns lugares eles são disfarçados, mas em outros são mais contundentes. É mais fácil revelar os processos aguçados.

Krasnuchkina - É necessário pensar não somente em si, mas considerar todas as circunstâncias dadas?

K.S. - Além das circunstâncias dadas, há momentos orgânicos.

Krasnichkina - Mas eles mudariam pelas circunstâncias dadas?

K.S. - Dependendo das circunstâncias dadas, alguns processos orgânicos serão disfarçados, mas outros aparecerão claramente.

Krasnuchkina - Mas tudo é necessário captar imediatamente nas circunstâncias dadas?

K.S. - É evidente por si, que, sem as circunstâncias dadas, até entrar no quarto vocês não podem.

Krasnichkina - Eu surjo na cena no fim do primeiro ato, mas antes disso acontecem alguns eventos importantes. E como devo agir, diante de tudo isso, desde o início? E adiante eu não apareço muito tempo, e depois já enlouqueço. É uma virada tão aguda.

K.S. - As passagens vocês devem unir, fantasiar, sentir. Isso é desejável.

Guinzbur - Mas, se eu analiso todos os processos orgânicos, imaginando logicamente uma única linha, o texto poderá me incomodar? Mas e os versos brancos?

K.S. - Por que você, em sua língua ruim, pode falar sobre importante e belo sentimento e na de Shakespeare não pode? Pode ser que incomode você que aqui se trate de versos e deva ser mantido o ritmo do verso? Mas isso será superado totalmente quando eu ensinar vocês a lerem versos com o metrônomo. A métrica do verso, inerente à obra, penetrará em vocês com tal profundidade que vai soar até o almoço e o jantar. Vocês verão que representar em prosa, por exemplo, A desgraça de ter gênio ${ }^{166}$ simplesmente não é possível.

${ }^{166}$ Peça de A. Griboiédov (1790-1829). N.T. 
A chave de meu método é apenas fazer desaparecer debaixo de vocês o solo de ator no qual vocês estão, e dar outro, verdadeiro, vivo. Vocês começam a me contar sobre a sua vida e não sobre Hamlet, a quem vocês não conhecem. No início isso será lento, fora do ritmo, mas depois essa linha completa-se, desenvolve-se sem passagens, e tudo fica fácil.

Se vocês aprenderem a trabalhar assim como eu lhes falo, conseguem passar o papel de Hamlet em alguns minutos. A cena com a mãe: quero entender; o que quer dizer entender? Compreendo. O encontro com Horácio: não compreendo totalmente. Repito. O que farei, como escutar tais notícias? Assim. Agora entendo. E assim por diante. Dessa forma vocês podem ensaiar a peça no caminho, durante o almoço; podem, durante o dia, executar umas oito vezes toda a peça e ficará a impressão de que já atuaram nesse papel. O papel será fixado em vocês pelas chamadas internas para a ação. Fortaleçam essa linha interna atual; se vocês a criarem e fortalecerem, podem ficar tranqüilos, pois não vão se perder em cena.

(Chur, Krugliak, Krasnuchkina relatam a terceira cena do primeiro ato. Viakhireva conduz a aula)

Vocês estão seguindo pela linha do texto, o que significa pela linha das circunstâncias dadas, mas vocês mesmos achem a linha do processo orgânico.

Krasnichkina - Qual é o processo orgânico aqui?

K.S. - O processo em toda a parte é igual. De toda forma, vocês, no final dos finais, chegam à relação. Sem relação não há o que fazer. Vocês devem encontrar os processos orgânicos e com a mais elementar relação.

(K.S. passa a trabalhar adiante com Krasnichkina e Chur na cena deles)

Krugliak - Se eu quero convencer a minha filha, talvez eu comece de algum ponto distante, com um tema abstrato.

K.S. - Se for necessário, vocês vão falar sobre o tempo. Vocês agora estão diante do papel, como diante do buraco de uma agulha, e tentam por todos os meios entrar nele, mas o encenador, nesses casos, ainda pega o ator pelas pernas e enfia a sua cabeça no buraco da agulha. Eu mesmo quero que vocês, por enquanto, captem do papel aquilo que vocês têm em comum com ele; por enquanto se trata da inter-relação, que é própria de todos os seres vivos. Assim vocês estudam, o processo da relação. Estudam a relação mais elementar. Vejam, antes nós iniciávamos os ensaios com o “período de mesa”. Nós nos sentávamos à mesa por um longo tempo. Confesso que essa “mesa” também eu a 
inventei. Mas eu não dou a "mesa” e com isso eu facilito o trabalho de vocês. Eu exijo de vocês aquilo que agora podem dar, a relação verdadeira.

Krugliak - Por que, quando eu saio na cena, eu me perco e perco aquilo que trabalhei?

K.S. - Porque as condições da arte em público arrastam vocês para a demonstração de si mesmos, mas eu peço o elementar, que realizem sua linha do papel com lógica. Vocês, na realidade, se perturbaram, nesse caso, com o meu artigo. ${ }^{167}$ Você chega ao teatro, conseqüentemente já está na cena, você é ator. Mas, chegando ao teatro imediatamente você se acostuma também com o pior que nele existe. Participando em cenas de massa, vocês devem perder muito tempo para olhar e entender tudo aquilo que vocês podem estudar cuidadosamente no primeiro ano de estada no estúdio. No teatro não pode haver ensino coletivo. Nesse caso, cada estudante deve ter o seu pedagogo, semelhante a uma governanta. Por isso, o mestre pode ter dois, no máximo três, estudantes. Se houver mais, eles voltarão a ser pobres figurantes. O público é um fator positivo importante para o ator. Nós necessitaríamos ter um grupo de espectadores durante o nosso trabalho. A tal liberdade, sobre a qual se fala, adquire-se naquilo que vocês identificarão como a lógica da ação e a lógica dos sentimentos e realizarão na cena. Mas em nenhum caso se deve sair em público com coisas inacabadas. Se vocês saírem em público com o papel inacabado, com o étude, com o espetáculo, então fixarão tudo isso que está ruim.

(K.S. novamente fala sobre o significado do desenvolvimento das mãos. Ele dá a palavra de ordem na nova década: as mãos são os olhos do corpo)

Hamlet - Shakespeare - 3 de junho de 1937 (pp.474-477)

\section{(K.S. pergunta sobre o estado do trabalho sobre Hamlet)}

K.S. - (a Viakhireva) Você não fica remoendo num único lugar? Os alunos pedem para falar o texto de Shakespeare? Eles não discutem demasiado? Você não está conduzindo tudo pelo pensamento? Na vez passada, eu observei essa tendência. Isso é prejudicial. Vamos trabalhar.

\footnotetext{
${ }^{167}$ No dia 8 de maio de 1937, em "Noticias”, foi publicado o artigo de K.S. "Caminho da arte”, no qual ele escreveu, em particular, sobre vantagens da "escola de passagem", escola junto com teatro. (Stanislávski, K.S. Coletânea tomo 6, p.397-401)
} 
(K.S. Pergunta aos estudantes se eles necessitam do texto do autor. Pelas opiniões, se esclarece que, por enquanto, ainda não é necessário o texto exato, mas os pensamentos e sua coerência)

Existe em vocês verdadeiro engate e verdadeira habilidade? Vocês entendem a diferença entre habilidade e engate? Vocês podem engatar-se aos olhos do partner, e não captar nada deles, mas podem pegar algo do partner e dar a ele algo.

Rozanova - Habilidade verdadeira ainda não há.

K.S. - É evidente, a visualização ainda é fraca. De onde você recebe as visualizações? Dos pensamentos?

Rozanova - Da idéia, das circunstâncias dadas, do partner.

K.S. - Começamos a trabalhar. O que você quer fazer, o que propõe?

Rozanova - Eu quero observar.

(Konstantin Stanislávski esclarece sobre a situação com os études, nos quais foi fixado o texto. Ele aprova a resposta do aluno, que, para fixar o texto, é necessário, cada vez, ativar a sua fantasia. Somente assim o texto não senta nos músculos da língua. Para isso é necessário mudar as circunstâncias dadas: sendo suficiente mudar a hora do dia, da manhã para a tarde)

(K.S. solicita que cada um lembre o trabalho que fez com o pedagogo)

K.S. - Vocês compreendem como é necessário proteger a linha ativa interna do papel, entrelaçado com tão grandioso trabalho? Quando essa teia estiver entrelaçada numa corda grossa, vocês já não terão nenhum medo do clichê. Vocês vão sentir que esse é um momento muito importante que deve guiar-se pelas leis da natureza e fortalecê-las. Aqui é necessário mais atenção interna. É muito importante pegar o ritmo verdadeiro, que deve vir das circunstâncias dadas. Um ritmo que foi captado incorretamente leva a interpretar a situação erradamente. Imagine que você vai coroarse e diante disso pula de alegria. Ou vai coroar-se como vai numa procissão fúnebre, atrás do caixão? Não esqueça as diferentes circunstâncias dadas. Não esqueça o “hoje” e o "aqui”. Lembre que “o hoje” e "o aqui” precisam desenvolver-se em cada um, para poder orientar-se bem na cena, adaptando-se ao estado de espírito atual do partner; pode ser que não gostem da estranha (para vocês) ambientação. (Respondendo, Ginzburg levanta, K.S. o faz sentar)

K.S. - Eu exijo que vocês levantem não porque eu sou algum general, querendo para si honras, mas porque vocês devem ter disciplina interna. Porém, quando nós começarmos a trabalhar, não precisam levantar. Não esqueçam que vocês devem treinar 
sua disciplina para que possam conduzir-se dignamente atrás dos bastidores; onde deverá haver silêncio absoluto. Eu estive uma vez na ópera no teatro na Alemanha. Na cena passa um navio no mar. O mar agita-se. Depois de um minuto de escuridão, acende-se a luz, e o que nós vemos: não havia mar nem navio, nada disso! Sentadas, vinte e cinco moças de cabelos dourados mexem na roca ${ }^{168}$. Que técnica magnífica e disciplina são necessárias para isso, para realizar tal mudança em absoluto silêncio! Eu peço a vocês, não ranjam com as cadeiras. Aprendam a levantar uma cadeira sem barulho, quando vocês querem locomovê-la. Isso tudo vocês precisam lembrar para cuidar do silêncio atrás dos bastidores. Se agora vocês não conseguem trabalhar em si mesmos, depois será tarde. Em alguns há uma maneira não adequada: reprimir os outros, mas não a si mesmos.

Ginzburg - Nós sempre temos que trabalhar em pequenos quartos. Nós somos em três. Às vezes até me acontece ter que me comunicar com pessoas imaginárias.

K.S. - Com partner imaginário nós temos que nos comunicar quando comparamos alguém com alguém, ou quando lembramos algo. Há ações materiais e imateriais. Nós agora nos encontramos não num pequeno quarto e nem em três - assim não é necessário alucinar-se. O ator gosta muito de relacionar-se com o imaginário, com objeto fantasiado por ele, mesmo quando ao lado dele, na cena, existe um objeto vivo. Além do objeto fantasiado freqüentemente ele não vê nada o que acontece ao redor e dessa maneira coloca uma parede a separá-lo do partner. Fantasiem, em um dia, uma coisa; em outro dia, outra. Muito freqüentemente as suas fantasias passam a vocês algo que não corresponde à peça, nem ao papel. Eu peço que se detenham somente no partner e usem aquilo que lhes dá a vida verdadeira. Até trabalhando em casa, nunca trabalhem com o partner imaginário; sente sua mãe, a empregada e lhes fale. Se isso não é possível, então é melhor raciocinar: o que eu faria, se meu partner fizesse tal coisa, e o que eu faria, se ele reagisse às minhas palavras de tal forma? Vocês podem sonhar a partir de si mesmos; isso também será impulso para a ação. O querer provoca a aspiração, mas na revelação dessa aspiração há ação; nós agora precisamos esclarecer somente o querer e a aspiração, isto é, o impulso para a ação.

\footnotetext{
${ }^{168}$ Com toda a probabilidade, K. S. tinha em vista a visita de solenidade do Wagner em Baireit em junho de 1902, onde teve a oportunidade de conhecer o mecanismo dos efeitos cênicos na realização da ópera "Holandês Voador”. "Lá, em toda cena,” - escreveu K. S., - "em direções diferentes estão navegando dois navios enormes; as ondas inundam os bordos, os navios se balançam. Eu vi, estando na cena, como dentro dos navios surgem doze pessoas e como elas, andando dentro do navio, o empurram em direções diferentes”. Moscou: “Arte”,1994, p.63.
} 
Ginzburg - Mas, se eu aceito “agora” e “aqui”, não posso aceitar o senhor, Zinaída Serguéivna ${ }^{169}$ e outras pessoas pelas personagens da peça.

K.S. - Eu, Zinaída Serguéivna e todos os que estão sentados ao meu lado todos, para vocês, são o público, mas seus companheiros, sentados com vocês na cena, esses, para vocês, não são público, mas pessoas na cena. Se vocês fizerem tudo para o público, podem se tornar escravos desse público. Nunca se dirijam ao público, caso contrário, vocês se escravizam a ele e nunca mais conseguirão escapar dessa escravidão. É necessário ter uma técnica grandiosa, para aprender a não notar o público. Temam depender da ribalta.

\section{(O trabalho continua)}

Agora, eu acredito em vocês, só olhem para que isso que ocorre em vocês não seja do pensamento.Vocês podem me enganar, mas enganar a si mesmos é impossível, e isso para vocês não passará de graça.

Orlova - Nós conduzimos toda a aula na discussão.

K.S. - Existem várias etapas no trabalho. Primeira, a relação orgânica, depois, pode ser discussões, mais adiante ação, idéias. É necessário passar por cada etapa. Mas por que vocês gostam tanto de discutir?

Estudante - Porque isso não é difícil.

K.S. - Quer dizer que vocês têm vontade fraca. Vocês não conseguem obrigar-se a agir. Porém discorrer demais não presta.

Skotnikóv - Como aprender a escutar um texto já enfadonho e conhecido há tempo?

K.S. - Em primeiro lugar, é necessário colocar o princípio - “se fosse”, em segundo lugar é necessário, de forma nova, imaginar claramente nas visualizações aquilo que lhes diz o partner, ou aquilo que você quer falar a ele.

\section{(O trabalho continua)}

(para Ginzburg) Você gentilmente e de forma humana falou sobre suas idéias, mas eu posso, agora, criticá-lo. Se você fosse o príncipe herdeiro, que deve inspirar respeito, como você se portaria? Nós necessitamos, através da técnica, ir ao subconsciente ou, se a intuição trabalhar, não deve atrapalhar o embrionário subconsciente.

\footnotetext{
${ }^{169}$ Zinaída Serguéivna Alekséieva Sokolova (1865-1950), irmã de K. Stanislávski, pedagoga e diretora do Estúdio de Ópera Bolshoi e mais tarde Teatro de Ópera Stanislávski. Trabalhou juntamente com K. Stanislávski na preparação de artistas-pedagogos sobre o "sistema". N.T.
} 
Akimov - Por que eu preciso falar em voz alta tudo aquilo que me acontece?

K.S. - Para obrigar-se mecanicamente a seguir as leis da natureza, sem excluir nada, enquanto isso não ocorra pelo hábito constante. Depois quando vocês tiverem isso dominado pelo treino, nós deixaremos esse procedimento. Vocês entendem o que se chama sistema? O sistema são as leis da natureza. Se trabalharmos em nós mesmos a habilidade de agir na cena pelas leis da natureza, não excluindo e não mentindo nada, então, coisa alguma poderá atrapalhar o nosso subconsciente. Nesse momento o sistema já não é necessário. Assim, para poder agir pelas leis da natureza, nós nos agarramos ao sistema, aos processos orgânicos, etc.

(Esclarece a relação entre Rosencrantz e Hamlet. Explica a mudança de visão de mundo de Hamlet depois de seu encontro com o Fantasma de seu pai. Depois do intervalo K.S. faz exercícios “toalete do ator” com os estudantes)

No próximo ano, chegando ao Estúdio, vocês deverão fazer a "toalete do ator" tal qual vocês fazem a sua toalete pessoal; isto é lavar o rosto, tomar chá, etc. Cada dia, vocês deverão fazer os exercícios com todos os elementos durante uns cinco ou seis minutos e só depois começar o trabalho artístico do dia. Primeiro fazer no ritmo, com música relaxar os músculos, unindo essa relaxação à execução de pequenas tarefas físicas. Com a música, já poderão concentrar sua atenção. Alguns necessitarão de mais tempo para isso, outros de menos, mas é necessário que tudo esteja no seu ritmo. É necessário, a partir da música, relacionar-se com o outro. Num ritmo - vocês encontram para si o objeto; e em outros ritmos, vocês chamam a atenção dele; num ritmo, vocês projetam os tentáculos nos olhos do objeto; em dois ritmos, vocês querem entender o que há com ele; em um ritmo - dão a ele a sua impressão, as idéias, depois desviam os olhos para o outro partner. Tempo - isto é, um compasso, ou dois compassos - pode-se aumentar na dependência do que a pessoa desejar.

Ação com objeto imaginário, com música. Tudo pode ser feito com música, como vocês viram agora: ação, objeto, relação, atenção, fantasia, verdade, sentimento (este vem ou não vem, mas deverá vir) e ingenuidade. A ingenuidade pela ingenuidade não é necessária, mas, se há verdade, há ingenuidade. A relação deve ser desenvolvida. Entabulem uma conversa ao longo da rua. Procurem um partner distante e experimentem comunicar-lhe algo. Estabelece-se não somente uma relação, mas uma adaptação também. O que em vocês não é suficiente?

Estudantes - As palavras. 
K.S. - Antes de falar sobre a palavra, é necessário falar sobre a dicção, a pronúncia correta do som.

(K.S. faz exercícios com os estudantes sobre a pronúncia de algumas letras, no coletivo).

\section{Hamlet - Shakespeare - Aula com o setor dramático: 26 de outubro de 1937} (pp.479-484)

(Stanislávski pergunta em que estágio se encontra o trabalho sobre Hamlet, V.A. Viakhireva fala).

K.S. - (para Rozanova) Como vai o seu trabalho e quais são as suas dificuldades? Vocês percebem a trilha a seguir, pela qual deve encaminhar-se o trabalho? O que preocupa vocês nesse trabalho, o que alegra?

Rozanova - Eu quero encontrar a linha ininterrupta do papel de Hamlet. A linha se interrompe, quando eu perco a lógica da idéia. É difícil para mim. Eu quero abrir os caminhos - os canais para a linha ininterrupta.

(Rozanova fala sobre a sua linha do papel)

K.S. - O que acontece com vocês no plano psicofísico? Não esqueçam que todas as ações orgânicas, por nossa natureza, são psíquicas e físicas. Isso não é segredo, nem para mim nem para vocês. Mas para não assustá-los, vamos chamá-las de físicas. Comunicam-lhes sobre a morte do pai - o que vocês farão?

Rozanova - Eu quero imaginar, como isso aconteceu. Para isso, necessito arrancar de Horácio o que ele sabe.

K.S. - Você não pode abarcar tudo o que aconteceu, por isso precisa usar alguma imaginação. Assim, vocês têm um momento da imaginação.

(Rozanova continua)

Rozanova - Eu quero esclarecer tudo detalhadamente.

K.S. - Qual processo está acontecendo com você? Houve o momento da imaginação. Agora ele continua. Vocês devem completar o quadro que imaginaram para si mesmos. Você esclarece o que aconteceu. Houve a representação, agora em você surge o julgamento. O julgamento sempre exige visualização prévia. O ator não tem o direito de sustentar o julgamento, enquanto não houver a visualização sobre qualquer fato, acontecimento. Nesse processo é necessário atrair todos os movimentos da vida psíquica. O que vocês fazem quando perdem a linha do papel? 
Rozanova - Eu volto atrás e procuro ver tudo, visualizar.

K.S. - Tenham cuidado somente para não fantasiarem abstratamente sobre algum Hamlet. Poderá existir no nosso tempo alguma história com Hamlet? Pode. Representem, imaginem que Hamlet existe hoje, aqui e agora. Vocês percebem no que consiste a diferença? Imaginem, que vocês têm de agir na presente situação, hoje, aqui. Eis a diferença. Se vocês entenderem isso, entenderão que eu mesmo, pelo caminho simples e direto, penetrei em suas almas e os obrigo a agir assim, como eu necessito. Vocês percebem que eu os obrigo a falar, agindo a partir de si mesmos. Tal personagem, que existe na peça, tal situação e tais circunstâncias dadas, involuntariamente se tornam reais para vocês. (Rozanova continua a falar)

(Para os estudantes) Vocês percebem que ela começa a falar de si mesma: eu sinto, eu quero. Isso é vontade e sentimento. Houve representação, julgamento, mas agora surgem a vontade e o sentimento.

\section{(Rozanova fala se adaptando à realidade)}

K.S. - É formidável que você toma tudo da realidade. Quer dizer, houve representação, julgamento, vontade e sentimento e, agora, ação. Vocês entendem como tudo ocorre sucessivamente?

Rozanova - Eu começo a ter consciência de onde está o pai, e protesto contra seu sofrimento.

K.S. - Isso não está correto, Hamlet vai raciocinar sobre isso dois meses depois que ele viu o Fantasma. Nesse momento vocês se defrontam com um fenômeno, que não podem esclarecer. Você somente assimila para si, somente escuta tal mistério, o qual ainda não conscientizou, porém sente. Vocês devem ter um cuidado terrível para não assustar o Fantasma.

Rozanova - Eu entendo que o pai me chama para se vingar, mas como fazê-lo?

K.S. - Se vocês já entenderam isso agora, o que vocês vão fazer em todos os quatro atos, que estão pela frente? A tarefa agora é assimilar o que o pai falou, mas analisar essas palavras vocês vão fazer depois. Agora vocês precisam falar baixo, não agitar demais as mãos, para não espantar o Fantasma. Hamlet não leva ainda do primeiro encontro com o Fantasma uma linha clara, porque ele duvida da aparição. Toda a tragédia de Hamlet consiste em que ele tomou para si uma tarefa acima de suas forças. Vocês esforçam-se para saber o mistério. Vocês viram o Fantasma e, após o encontro com ele, estão somente no ponto de partida. Vocês não sabem nada, não entendem nada. Vocês devem viver desde o início. Começa o novo ato, nova vida, aqui 
há sobre o que pensar. Vocês continuam a viver, mas já em novas circunstâncias dadas. Quando vocês se encontrarem com Rosencrantz, com Polônio e com os outros, vocês não entenderão como é possível viver em tal mundo, interessar-se por ninharias, quando há algo grandioso. Nisso reside a tragédia em Hamlet; suas dúvidas são iguais a de todos os povos, por todos os séculos.

O ser humano quer entender o sentido da vida. Da força de que ele vive. Vocês começam a agir para saber o sentido da existência. O que fariam caso se encontrassem em tal situação? A tendência humana é, antes de tudo, procurar a ajuda de outros. Mas ninguém pode ajudá-los nisso. Comecem por si sós a vaguear pela vida e revalorizá-la. Por isso Hamlet muda nesse momento. Antes, ele era um homem comum, alegre. Depois de conversar com o Fantasma do pai, ele não consegue ficar alegre, começando nova peça, nova vida. Hamlet já não pode aceitar perto do coração aquilo que o cerca, porque ele conheceu algo maior, mais significativo. Prestem atenção em que Hamlet tornou-se ativo e permaneceu ele mesmo diante do encontro com os atores. Vendo que o homem-ator pode chorar e comiserar-se de algum destino desconhecido, Hamlet começa a entender que ele também é capaz de fazer muito, de enfrentar aquilo que tinha a impressão de não poder dominar.

Agindo lógica e coerentemente, você força a sua natureza orgânica a trabalhar e, dessa forma, o subconsciente. Em nossa arte isto é fundamental, através do consciente alcançar o subconsciente. Nós somente podemos acordar aqueles centros que levam à arte, com os meios diretos nós não podemos governá-los.

(Stanislávski solicita aos alunos "extrair” algumas linhas de Hamlet e fazer delas études, como na aula passada. Os estudantes fazem étude).

Agora eu sinto que, através de simples ações físicas, vocês conseguem acordar a inteligência, a vontade e o sentimento e fazê-los trabalhar. Quando vocês os puxarem, surge o sentimento de verdade e a imaginação. Uma vez que há imaginação e sentimento de verdade, significa que surge a crença. Atraindo, no trabalho, toda sua vida psicológica, vocês estendem a linha, que necessitam. Assim, vocês aprenderão a trabalhar a sós. Somente por esse caminho vocês chegarão à maestria. Não há diretor que possa levá-los a isso. Vocês devem aprender a trabalhar sozinhos.

Vocês têm possibilidade de trabalhar qualquer peça pela linha física, fazer études em qualquer linha da peça, e nenhum de vocês têm a audácia de me dizer que não há nada a fazer. Em primeiro lugar, não deixem de lado os antigos études, aprofundem-nos e repitam-nos; em segundo lugar, façam os próximos études para aquelas peças, que 
vocês estão trabalhando agora. Trabalhem mais vocês mesmos, mostrem ao pedagogo o trabalho independente já feito. Seria bom que o texto não canse os seus ouvidos. Imaginem quão avidamente vocês pegarão as frases do texto, se elas expressarem exatamente aquilo que há tempo vocês entenderam pela lógica da idéia.

(Os estudantes Menchikov e Rozniatovskii mostram o étude "Longe, longe no Oriente”)

K.S. - Em todos os études não há finalização. Vocês não conseguem colocar o ponto final. No início, há pausa pela pausa. É necessário esforçar-se para eliminá-las. Mas, em geral, está bem. O que pode ser feito com esse étude para que se torne mais colorido?

Estudante - Aprofundar as circunstâncias dadas.

(Manifestam-se opiniões sobre a mudança da estrutura do étude. K.S. fala, que ninguém, lamentavelmente, pensa ou propõe como aprofundar o étude)

K.S. - Vocês não peguem um caso particular para fazer o étude, mas por exemplo, peguem um trabalho importante do Estado. Em outras palavras, para aprofundar o étude, é necessário haver um superobjetivo mais significativo. Não selecionem études nos quais não há profundidade. As obras geniais não têm fundo. Não esqueçam que o papel é só uma parte da vida da personagem da peça. Imaginem a vida humana como um círculo fechado, que começa com o nascimento e termina com a morte. Suponhamos que isso é o globo terrestre. O pedaço, do ponto $\mathbf{R}$ até o ponto $\mathbf{A}$, vocês mostram na cena. Em cada vida humana, como no globo terrestre, há camadas. No centro, é claro, está o superobjetivo, a essência do ser humano. Quanto mais profundamente vocês conseguem chegar às camadas, mais perto estarão do superobjetivo. O objetivo do ator é cavar até o centro da terra, que significa chegar ao superobjetivo. Quanto mais vocês aprofundarem os études, tanto melhor. É necessário não ir pela linha externa da fábula, como geralmente fazem os estudantes e até os pedagogos. Esforcem-se para fazer études com interesse, isto é, aprofundá-los, complementando-os com conteúdo. Isso é possível. Façam os études independentemente e mostrem para o pedagogo. Não os joguem fora no caminho. Se os études não estão inscritos na programação, façam-nos de forma independente, nenhum professor se negará a ajudá-los. ${ }^{170}$

${ }^{170}$ O estenograma da aula continua com os estudantes lendo poemas de Maiakovski, que foram suprimidos nesta tradução, em que K. Stanislávski faz correções e observações sobre o ritmo do verso, a dicção, etc. N.T. 


\section{Hamlet - Shakespeare: 7 de março de 1938}

(pp.488-491)

(Stanislávski solicita iniciar a aula com a "toalete do ator". Os alunos fazem os exercícios, depois disso apresentam o trabalho feito sobre Hamlet. Ensaiam a segunda, quarta, quinta e sexta cena de Hamlet)

K.S. - (para Rozanova) Como você se sentiu?

Rozanova - Mal.

K.S. - Com o que está contente e com o que não está?

Rozanova - Eu me confundi aqui. Nós estávamos acostumados com outro espaço. Não senti a linha lógica, às vezes perdi partes dela. Não fiz aquilo que queria fazer.

K.S. - Que critérios vocês se colocam? O que quer dizer "eu atuei bem”, o que quer dizer “eu atuei mal?”

Rozanova - Quando a lógica da linha do papel se estica, como uma corda, e não se rompe, eu não me perco e me sinto bem.

K.S - Isso ainda não é tudo. Mas o que há mais?

Rozanova - Grande ligação com o partner.

K.S. - O que é mais importante, para que vocês vão para a cena?

Estudantes - Agir.

K.S. - Sim, isso é o mais importante - a ação física. O importante é perguntar a si mesmo: “o que eu faria hoje, aqui, nas atuais circunstâncias dadas?”. Esse é o critério do ator. É mais fácil dizer “o que eu faria” do que “o que eu sentiria”.

Ginsburg - Hoje eu não fiz aquilo que é habitual, e não fiz tudo o que queria. Bem no início eu agi como queria. Mas adiante, a partir do momento do diálogo, eu como que avancei ativamente em Hamlet.

K.S. - Em que isso se expressou?

Ginsburg - Eu queria provar a ele o meu amor e fiz isso muito ativamente.

K.S. - Em que sentido "ativamente”? Você avançou nele como ator? Como ser humano, você não faria isso?

Ginsburg - Agora eu o faria como ser humano, se colocado nessas circunstâncias dadas. 
K.S. - Você fala das idéias de Shakespeare, mas mistura o texto do autor com o seu texto. Sente a necessidade do texto de Shakespeare? Ele é lido para você?

Martianov - Quando nós não entendemos as ações, pegamos a peça de Shakespeare. O texto nos ajuda muito e é fácil de decorar.

Kruliak - Eu tenho uma frase na qual as ações alternam-se claramente. E involuntariamente, quando analisamos minhas ações, eu lembrava o texto, a frase.

K.S. - Vocês entendem a diferença entre ação e tarefa? Dividiram o texto nos objetivos?

Viakhireva - Nós no início trabalhamos totalmente sem o texto. Mas no texto procuramos as ações.

K.S. - É necessário entender exatamente de onde vem a tarefa e de onde vem a ação. A tarefa vem da cabeça, e a ação vem da intuição.

Chur - Minha principal tarefa é observar tudo o que acontece aqui, e a interrelação das pessoas ao meu redor.

K.S. - Você é Polônio, um político terrível. Você deve combinar tudo. Você olha para tudo o que se faz ao redor, com enorme atenção. Você deve descobrir detalhadamente todas as inter-relações. O fundamental para você é essa enorme atenção, que perpassa todas as suas ações. Para ser Polônio, vocês não devem interpretar a astúcia, (é impossível interpretar a astúcia), mas devem ter enorme atenção, que não superficial, capaz de penetrar na alma humana. A partir dessa atenção, vocês iniciam a transformação em Polônio. Agora vamos falar sobre onde termina a fala prosaica e onde começa a fala romântica. Fala romântica não quer dizer vibração, tremor de voz e entonação afetada. No que consiste a diferença - como se deve representar Shakespeare e como se deve representar Tchekhov? É possível interpretá-los de maneira igual?

Chur - Em Tchekhov, há semitom.

K.S. - Com Salvini ${ }^{171}$, há semitons em Otelo! Sim e com Duse ${ }^{172}$ também.

Piatnitskaia - Shakespeare é muito difícil de pronunciar. Ele arrasta para a ênfase.

K.S. - O que é a tal ênfase? Essa ênfase é a pronuncia dos cantores. De onde vem essa obscenidade? Se vocês falarem “Kh-o-r-o-ch-a-ia-p-o-g-o-d-a” [bom tempo], assim como vocês falam: "Minha alma está plena”, nisso haverá ênfase. Em Shakespeare, há grandes idéias, mas sobre a grandiosidade não se pode falar como se

\footnotetext{
${ }^{171}$ Tommaso Salvini (1929-1916), ator-trágico italiano. N.T.

172 Eleonora Duse (1858-1924), atriz italiana. N.T.
} 
fala sobre os frios no café da manhã. Quando Salvini começa a atuar, ele nem ergue as mãos, não faz nenhum gesto. Ele nunca se apressa, jamais! E a própria elevação soa de forma simples, mas significativa. Nós lembraremos cada frase dele. Alguns pensam que para a elevação da voz é necessário fabricar algum truque. Cada vogal deve soar, cada consoante deve voar. Se vocês pensam que todo o trabalho consiste na exatidão da dicção, isso será a sua destruição. Vocês devem amar a idéia, ver a sua lógica. Não se deve declamar as frases. Vocês percebem que eu, até estático, não paro de conversar com vocês. Isso não é parada nem buraco, isso é falar no silêncio. A comunicação com vocês eu não interrompo. Não se apressem, isso é o mais importante. Dêem a idéia... Se eu falo e quero ser convincente, eu me torno mais exigente, eu reforço a entonação, eu me imponho para que todos me escutem. Quando eu aprofundo as circunstâncias dadas, dou à idéia maior significado, muda em mim o diapasão da fala. A elevação do estilo inicia lá, onde há maior conteúdo. O mais importante é não se apressar, falem cada palavra até o fim.

(Como exemplo, K.S. lê o monólogo de Otelo no Senado)

Vocês percebem que partes estão aqui, como é necessário dá-las. A elevação também deve ser simples, mas profunda, significativa, aqui deve haver, principalmente, visualizações exatas. E isso absolutamente não quer dizer que na elevação é necessário falar uivado. Não se deve ir somente pela maneira de falar, pois aqui surge o uivo. É importante entender que a tragédia é algo significativo e elevado, e isso cria a ampliação e o aprofundamento das circunstâncias dadas e as suas corretas valorizações.

Rozanova - Eu tenho muito medo de uivar e me esforcei muito para me conter, mas às vezes tenho vontade de libertar os movimentos. Por exemplo, quando o Fantasma avança para Hamlet, eu quero me afastar.

K.S. - Isso que você agora me mostra, isso é afetado. Isso é ênfase. Isso em caso nenhum deve ser feito. O primeiro sinal da ênfase: falar e não ver nada.

(K.S. explica a linha de ação do primeiro quadro. Fala que o modo de se conter depende das circunstâncias dadas)

Ginsburg - Para mim é difícil dizer a fala do trono, quando ao meu redor há poucas pessoas.

K.S. - Como poucas? Mas Polônio! Será que você sabe o que é isso, falar do trono? Amanhã, será noticiado em todos os jornais, não somente do vosso país, mas também de outros paises. Você entende o que é essa responsabilidade? Você entende que, se você começa a confundir-se, isso causará uma má impressão em todos, por isso 
você deve expressar tudo corajosamente e de modo imponente. Agora você tem uma boa transmissão da idéia. Há a linha da ação das palavras. Hoje vocês tiveram a ação da palavra, e isso é muito valioso. Lembrem, que vocês sempre agirão com a palavra, quando vocês tiverem a linha física forte. A linha física - esse é o trilho para o caminho pelo qual, se fortemente calçados, vocês podem ir para todos os lados, para qualquer lugar. Eu posso presentear vocês com outras circunstâncias dadas, mas nelas vocês não devem se perder, mas sim conduzir sua linha física.

Ginsburg - Em Shakespeare o texto é tão rico que, quando eu começo a falar sobre ele, eu expresso muitas idéias no lugar de uma do autor; para mim é difícil retornar ao texto e dizer tudo numa única frase.

K.S. - Se atrás de uma única frase há muitas idéias, isso a enriquecerá. O mais importante, é que vocês não percam o que vocês adquiriram. O principal é que o texto não repouse sob os músculos da língua.

Viakhireva - Isso quer dizer que agora é necessário ir pela linha de ampliação das circunstâncias dadas?

K.S. - Sim, mas é necessário não se conduzir pela maneira de falar, mas pela idéia, pela visualização.

(Martianov pergunta como falar, quando, pelas circunstâncias dadas, é necessário falar em sussurro. K.S. traz, como exemplo, Salvini quando sussurra no papel de Otelo)

Viakhireva - Quer dizer que é necessário partir do fundamento que os estudantes falem significativamente, exato e alto.

K.S. - Sim, necessariamente. Se você disser as mais belas idéias de forma não exata, ninguém se comoverá. Lembrem-se, quando vocês falam baixo, de modo impossível de ser escutado pelas pessoas que estão ao redor, isso quer dizer que vocês não têm certeza daquilo que falam, e não avaliaram suficientemente as circunstâncias dadas. Provavelmente vocês estão agindo, mas a metade da frase eu não escuto. Quando vocês não dominam a voz, quando não conseguem falar a idéia de forma clara, forte, exata, quando não conseguem transmitir o som como se ele voasse para os ouvintes, vocês tentam cobrir essas insuficiências com voz exagerada. Isso resulta em ênfase, mas o som sai de vocês da mesma maneira e não alcança, onde é necessário.

Viakhireva - Pode-se dar aos estudantes trajes, capas, esporas, espadas? 
K.S.- Capas, esporas, espadas já pode dar. Deixe que se acostumem. Chegando ao estúdio, permita que o elenco de Hamlet vista capas. Eu mostrarei como utilizá-las. Mas ao protagonista de Hamlet pode dar o traje.

\section{Hamlet - Shakespeare: 13 de junho de 1938}

(pp.503-512)

Viakhireva - Eu gostaria que o senhor visse nosso trabalho sobre Hamlet e nos ajudasse.

K.S - É claro, é necessário inicialmente vê-lo.

(Aos estudantes) Adotem nos assentos uma posição realmente confortável, para sentirem-se melhor, como em casa. Agora vocês estão sentados na platéia.

Viakhireva - Mantendo todas as regras de boas-maneiras.

K.S. - Em que sentindo? Não é necessário relaxar como após o banho. Aqueles músculos, que devem estar tensos, deixem-nos tensos, mas vocês devem estar totalmente livres. Cheguem até onde vocês possam dizer: "agora estou sentado tranqüilamente, é impossível ficar mais tranqüilo”. Freqüentemente, consegue-se essa liberação, essa liberdade nas ações; ficar preso na imobilidade, também não vai servir para nada.

Viakhireva - (aos estudantes) Olhem para o tapete e digam quantas flores há nele.

K.S. - Por acaso, vocês não podem fazer isso na posição em que estão sentados?

Estudante - Mas as flores se misturam.

K.S. - Sim, se isso for necessário...

Viakhireva - Tânia, para você quantas há?

Estudante - (conta) Sete.

Viakhireva - (ao estudante) Se você agora saísse da entrada e fosse à direita, o que você veria?

Estudante - Saí do portão. Na minha frente vejo o museu Kustarnyi, e vou dobrar à direita. Nesse lado, há um grande edifício de três andares. Em frente do consulado alemão, sempre está um policial. Também lá sempre se encontra uma motocicleta estacionada. Vou adiante. Encontro um portão, depois uma casa branca. A 
travessa está à direita. Eu vou adiante. Passo pela rua de K. Stanislávski ${ }^{173}$, e à esquerda há ainda outra travessa, não lembro como ela se chama.

Viakhireva - Lembrem o que vocês fizeram hoje pela manhã, e lembrando, andem de forma que vocês se sintam confortáveis.

K.S. - Pensem sobre os músculos, para que eles estejam livres.

Viakhireva - Quando lembrarem, comecem a tamborilar o ritmo.

(Os estudantes tamborilam o ritmo)

K.S. (para Viakhireva) - Nesse ritmo não se deve começar a trabalhar, é necessário tranqüilizá-los. Distrair com algo a atenção dos estudantes. Lembrem que vocês no início não entendiam o significado da "toalete do ator".

Estudantes - Antes nós fazíamos a “toalete" pela "toalete”, mas quando começamos a fazer a “toalete do ator” para a peça, ela passou a nos ajudar muito. Antes a fazíamos sem objetivo - simplesmente não compreendíamos sua utilidade.

K.S. - Isso é a afinação. Não se deve tocar um instrumento sem afiná-lo. O treino consiste em obter o estado de espírito verdadeiro, obter o genuíno estado de ânimo do meio do dia. Aqui, é necessário disciplinar todos aqueles fatores que utilizamos para a atuação. É preciso atingir o verdadeiro estado, isto é, o “posso atuar”.

Viakhireva (para Rozanova) - Ira, ache algum lugar e todos os demais vão adaptar-se a partir de você. (realizam a tarefa). Agora Tânia Krasnuchkina e todos os demais devem adaptar-se por ela. (realizam a tarefa)

Coloquem os móveis para Hamlet. (Ensaios das cenas de Hamlet)

K.S. - Como vocês se sentiram? O que saiu e o que não saiu? O que não foi agradável? O príncipe como está?

Rozanova - De diferentes maneiras.

K.S. - Onde, o quê? Relate, fale.

Rozanova - Na primeira cena com o rei, eu não senti nada. Como isso chegou ao senhor? Eu tenho pelo rei uma grande antipatia. Quanto à mãe, acho que a eu a amo mais, que é necessário falar com mais amor: “Mãe, o que tu estás fazendo, recobre os sentidos”. Para mim é muito difícil esse monólogo.

K.S - Você viu a troca de olhares entre rei e a rainha? Ele está no trono, ela está alegre. Se você fosse Hamlet, o que faria? Entrem nesse estado.

\footnotetext{
${ }^{173}$ Devido ao aniversário de 75 anos de K. S. com o decreto de Presidium do Soviete Supremo, a travessa Leontiévski, onde viveu K. S., passou a ter o seu nome.
} 
Rozanova - Eu me esforçaria para entender, indagaria, mas como não posso simplesmente interrogar, é necessário mergulhar nesse trabalho, questionar por que tudo isso aconteceu.

K.S - Aprofunde. Nesse monólogo de Hamlet não há nada para você fazer porque, o que você antes disso já representou. Antes de começar a odiar, é necessário orientar-se de alguma maneira - como viver, para onde ir. Pela peça, Hamlet não entenderá logo tudo. Ele ainda vai para a mãe. Simplesmente olham, como isso pôde acontecer tão rápido. Mas você já representou tudo. Veja o que significa falta de lógica. Você saiu sem lógica e atuou aquilo que na peça ainda não existe. Veja que o rei e a rainha se entreolham, e internamente, em Hamlet, algo desabou. Ele mal pode conter-se, para não invadir a alma da mãe. O que é isso? Que rei é ele? Você não pode aceitar isso.

Rozanova - Aqui há conflito...

K.S. - O conflito principal significativo será mais adiante. Quanto vocês precisam ainda entender! O pai morreu, a mãe se casou. Com isso é necessário se conformar. E se ligar na vida. Isso deve ser digerido de algum modo. Mas vocês sabem tudo desde o início da peça, toda a peça já é conhecida, mas como você manifestou imediatamente o conhecimento, não tem mais nada a atuar. Vocês percebem como a peça está escrita? Aqui toda ação está contida nas palavras. Vocês ainda não possuem a ação da palavra. Hoje nove décimos eu não entendi, porque você não fez o acento correto. Há palavras, mas não frases. O que é difícil na peça de Shakespeare? Aqui não há nenhuma palavra que seja possível omitir, não entender. Aqui há o pensamento da pessoa e, se vocês o suprimirem, jogarão fora alguma parte da peça. Mas dezenas de palavras e idéias não chegam a vocês. No sentido da dicção, no sentido de moldar as frases, vocês não fizeram nada. Nós não falamos a respeito da ação da palavra; a dicção de vocês está muito fraca. Vocês entendem, como isso é importante aqui? Vocês começarem a modular a voz de algum jeito. Lembro que quando falavam com as próprias palavras, vocês expressavam muito bem a idéia. Agora eu já não entendi nada. Se não há ação, e vocês não têm consciência, de que as palavras expressam ação, então já surge o sentimento do ator: inicia-se a inábil afetação, a ênfase. E, graças a Deus, que é inábil, porque se fosse habilidosa, seria ainda mais difícil corrigi-la.

Sobre o que você precisa esforçar-se, para conseguir isso? Vocês não devem ficar confusos por eu criticá-los assim. Mas vocês pegaram como trabalho aquilo com que um ator deve terminar sua carreira. Alta dificuldade, em nossa arte - isso é Hamlet. Mas eu o dei a vocês. Vocês, em Hamlet, entenderão tudo o que os sentimentos e as 
palavras grandes exigem. O que há aqui de ruim? Vocês vão procurar, viver de Hamlet dessa melhor obra de arte. Vocês escolheram o Hamlet com base no raciocínio de que vocês têm temperamento forte.

Rozanova - Não, claro, eu não vou parar nisso. Aqui é exigido um trabalho enorme.

K.S. - Vocês fizeram um trabalho enorme, extenuante, porém um trabalho importante. Se vocês nesse trabalho alcançarem êxito, isso pode ser comparado a cem peças de Ostrovski. Assim se esforcem para superar todas as dificuldades. As dificuldades aqui são enormes, mas essas dificuldades não são restritas a essa peça; boa dicção deve haver em todas as peças, autodomínio deve haver em todas as peças, ação da palavra deverá haver em todas as peças. Dessa forma, tudo aquilo que fazemos aqui, é necessário em outras peças também, mas nessa peça é mais difícil de conseguir do que em outras. Aqui tudo deve ser extraordinariamente simples. Mas assim que você buscar simplicidade consegue trivialidade, vulgaridade, algo mesquinho. Isso significa que não é necessária a simplicidade? Não, a simplicidade é necessária, mas, diante disso, vocês devem ter a voz colocada, devem dizer a frase sem pressa: falar a frase e esperar; será que ela foi? Deve haver um domínio incrível, amor pela frase, pela idéia. Quando houver tudo isso, vocês amarão a palavra, e poderão sentar-se totalmente tranqüilos, e o espectador poderá comentar: “Por favor, não é necessário mais nada, nenhuma mise-enscène, aqui já não há nada a acrescentar”.

Experimente simplesmente dizer o texto pelo sentido. Por que vocês não fazem algo agora? Deixem-me escutar como soam as palavras.

Rozanova - Eu estou me concentrando.

K.S. - Vocês estão aglutinando o sentimento que necessitam. Contra a sua consciência, estão se preparando para representar o sentimento. Não se deve fazer isso. Se eu lhes peço para dizer somente a própria idéia, vocês vão ver que o sentido verdadeiro da palavra puxa-os para a emoção. Mas se tentarem transmitir os sentimentos, eles fogem de você.

Não esqueçam o que falou Salvini: somente no quinto ato das tragédias Otelo, ou Hamlet, aflige-se, emociona-se, e por, no máximo meia hora; o restante do tempo ele fala, transmite a idéia.

Mas eu quero dar em suas mãos, o que ajudará vocês a pegar o papel pelo próprio coração. Experimentem falar a idéia, mas expressando bem somente esse 
sentido. Esforcem-se para transmitir as imagens dessa idéia. Peguem a peça e falem o texto pelo sentido.

Rozanova - “O, esli b etot plotnyi sgustok miassa

Nispal rossoi”.

[Oh, se esta densa carne poluída]

[Caísse como orvalho]

K.S. - Eu não entendi, para que vocês necessitam disso. Expliquem o sentido. O que isso quer dizer. Vocês se apressam muito, mas vocês têm que desenhar o quadro. (fala o texto do papel) O que é isso? O que aconteceu?

Rozanova - “O esli b etot plotnyi sgustok miassa...”. [Oh, se esta densa carne poluída...]

K.S. - Você não tem o direito de parar nem por um segundo. Não tem o direito de interromper o som. Esse deve ser uma nota contínua. Você não tem cantilena. Toda a frase deve ser entregue assim, sem que em nenhum lugar seja interrompida.

Rozanova - “O, esli b etot plotnyi sgustok miassa

Nispal rossoi, tumanom isparilsia...”.

[Oh, se esta densa carne poluída]

[Caísse como orvalho, como neblina se evaporasse]

K.S. - Isso tudo é um quadro enorme. “Nispal rossoi...” [Caísse como orvalho...] - e deve ser contido. Onde você faz o acento? Aqui você tem uma tal pressa! Quando você fala uma frase grande, não deve separar o sujeito do predicado, eles devem estar juntos, ligados, mas não tropeçar um no outro. Deve haver forma. Não pode ser duas notas iguais.

(Repetição)

K.S. - Por que á palavra "tumanom” [como neblina] você está dando esse significado? Você não está indo pelo caminho correto, você está indo pela respiração, pela pronúncia. “Tumanom isparilsia” [como neblina se evaporasse] - isso deve ser uma frase acabada. Vá adiante, molde outra frase. Não despeja uma atrás da outra. Isso quer dizer, sobre o que você está falando?

Rozanova - “O, elsi bi Predvetchnyi ne zapretil grekha samoubiistva...”. [Oh, se não tivesse o Eterno proibido o pecado do suicídio...]

K.S. - Dois adjetivos, dois substantivos, o caso genitivo. Você começa a apressar essas palavras - “O, esli bi Predvetchnyi...” [Oh, se não tivesse o Eterno...] Esse ritmo fica. Percebam que a frase cresce em vocês. Falem isso com amor. "Grekha 
samoubiistva” [o pecado do suicídio]; “bi” [se] - é a sílaba mais alta. Vá daqui para a nota mais alta: “O Boje moi, o Boje miloserdnyi..." [Oh Deus meu, oh Deus misericordioso...] Somente aumenta, não precisa mais nada. Onde está a dificuldade aqui? Está em ser necessário ir até o fim da fala.

Eu aconselho vocês a diariamente pegar qualquer página de jornal e ler cada palavra até o fim - para experimentar sentir a palavra. Quando vocês aprenderem a ler dessa maneira, junto com uma boa colocação da voz e com a respiração correta, essa nota já soará como nota de gaita de fole e em vocês haverá cantilena. Isso tudo é terrivelmente importante. Nisso consiste todo o segredo.

Se em você a voz não soa, não vibra, não produz ressonância, você começa a procurar algo que a obrigue a soar. Então iniciam-se todas essas coisas. O que origina essa má ênfase? Simplesmente a voz não soa, não está colocada. Assim ficam sabendo, o quanto é importante a colocação da voz. E colocação da voz não é usá-la naquilo que cantarem uma vez em três, cinco dias. Não é nisso que reside o trabalho. Vocês devem entender de quais exercícios precisam. Vocês dirão que não têm instrumento. Mas vocês podem usar o diapasão, o assobio. Lembro como eu treinava minha voz na América. Na América, nos hotéis, não se pode cantar alto. Mas lá há pequenas peças onde se penduram os vestidos. E eu entrava nesses armários, me trancava e lá eu cantava ${ }^{174}$. Quando voltei para casa, em Moscou, Nemiróvitch não reconheceu minha voz pelo telefone. No enterro de Iujin, fiz um discurso na rua perto da entrada para o Teatro de Arte $^{175}$.

Dessa forma, toda a pergunta diz respeito aos exercícios diários. E se eu agora cantasse antes de falar com vocês, eu poderia falar durante cinco horas, e quanto mais, melhor será. Forte, fortíssimo vai soar em vocês, se houver piano e pianíssimo [...]

No início é necessário obrigar-se a trabalhar. A voz sai, como forte lança aguda, e nessa ponta é necessário vestir as palavras. Já faz tempo uma cantora falou-me que sorver ao mesmo tempo oxigênio pelo nariz e pela boca proporciona uma respiração mais rápida e completa.

\footnotetext{
${ }^{174}$ Teatro de Arte, guiado por K. S., estava em tournée artística nos USA em 1923-1924.

17525 de outubro de 1927 (dia do enterro do ator e diretor do teatro Mali, A. Iujin) K.S. discursou perto do edifício do TAM, onde parou o cortejo fúnebre com os restos mortais de Iujina no caminho do teatro Mali até túmulo de Novodevitchi Monastyr. K.S. "com grande elevação fez o discurso, quando carregaram o caixão ao lado do TAM, - escreveu Lujski para Nemiróvitch-Dântchenko.- Não sei, pode ser porque a travessa era estreita e as portas do teatro foram abertas... mas a voz do idoso tornou-se de tal forma forte, que a emoção originou nele a verdadeira ênfase, e o discurso provocou enorme impressão". N.D. número 8958.
} 
Estudante - Por acaso é possível respirar ao mesmo tempo pela boca e pelo nariz?

\section{(K.S. demonstra)}

Martianov - É muito difícil. Exaspera-me aquele período extenso, que corresponde às primeiras falas do rei, no qual eu não consigo me compreender. A respiração não é suficiente e não sei onde buscá-la.

K.S - Aqui pode haver vinte respirações. (mostra) Qual é o sentido dessa frase e como transmiti-lo? Você se casou com a irmã e a rainha. É necessário ir até embaixo e depois subir até o alto. “A irmã e a rainha - herdeira de um país guerreiro”, “nós, como se fosse com o triunfo perturbado (pausa), pegamos como esposa...”. Exatamente nesse domínio há ação. E na prosa deve haver ritmo. Em cada frase, há alguns ritmos. Por exemplo, em Gogol, há um ritmo extraordinário, que deve ser expresso exatamente. Aqui, em Shakespeare, há a precisão de um comportamento especial. Quando você fala: “Prezados companheiros..." etc. - esse é um ritmo, mas quando Otelo, no Senado, deve falar: "Respeitáveis e nobres senhores...” - é totalmente diferente.

Vocês percebem como é necessário não se apressar? Vocês não podem, ao dizer seu monólogo, não senti-lo. Se falarem com precisão, o público os seguirá pela linha pela qual o conduzem.

Estudante - Mas como chegar a isso mais rápido?

K.S - Quanto maior for a frase, quanto mais espessa, tanto mais preciso levá-la até o fim. Peguem a tal fala do "trono": "Rimliane, sograjdane, druzia”"176 (Romanos, concidadãos, amigos...). Vejam, que pausas devem ser feitas, para chegar até o povo? Percebem em que porções é necessário transmitir isso?

Rozanova - Certamente, na comunicação com o partner a frase poderá construirse, se analisarmos o texto logicamente. E quando for monólogo? Aqui eu devo colocar perguntas para mim mesmo e respondê-las. Ou possuir um objeto imaginário.

K.S - Aqui há uma comunicação, o cérebro, mas a outra é o plexo solar. Uma é a idéia, a outra é o sentimento, e quando a cabeça fala com o plexo solar, você pode dizer a ele: sim, pois eu te falei isso e isso... Ou vocês possuem o objeto imaginário e passam a ele. Portanto, tudo depende das circunstâncias dadas. Mas, realmente esse é o tipo de comunicação mais difícil. Como se trata do papel de Hamlet, é necessário falar sobre isso agora?

\footnotetext{
${ }^{176}$ Palavras iniciais da fala de Brutus diante do povo depois da morte de Júlio César (“Júlio César”, ato 3, cena 2).
} 
Estudante - Por favor, fale!

K.S. - A mãe não sabe de nada, não entende nada, morrerá e não entenderá nada. Como salvá-la?

Você, Hamlet, deverá pegar a espada e caminhar, andar por todo o palácio e limpar tudo, somente assim você poderá salvar o pai. Com um messias, você deve ir, andar por todo o mundo e limpá-lo. Essa é a idéia, essa é a tarefa, dada a Hamlet pelo pai, e você deve realizá-la, pois somente realizando-a se sentirá bem.

Assim, você descobriu que o pai foi morto, e você não entende nada: como pode haver tais pessoas, como pode a mãe, sem gastar um par de sapatos, ser feliz com outro. Em seguida aparece o Fantasma do pai. Agora você fala com o Fantasma como a um soldado, mas, na realidade, ele é um homem agoniado, no limite das suas forças. Aqui você novamente descobre algo novo e especial. Qual é o superobjetivo de Hamlet?

Estudante - O homem que se enfrentou com a vida.

K.S. - Isso diz respeito ao conteúdo, mas qual é o superobjetivo?

Estudante - Procurar a verdade da vida.

K.S. - O conhecimento da existência. Para quê, por quê, o quê.

Rozanova - Quando eu fiz assim, me disseram, que saí a algum filósofo.

K.S. - O conhecimento da existência. Entender por que tudo aquilo pôde acontecer. Chega o Fantasma do pai; é necessário olhar o Fantasma, saber tudo sobre ele, o que for possível. Chega Ofélia - é necessário perscrutar sua alma. Hamlet quer saber tudo, mas não arrazoa de maneira nenhuma. Com algumas palavras, façam todo o possível para saber, conhecer, tudo aquilo que a vocês não é dado. Vocês sofrem, porque não podem fazer o impossível.

(Ensaiam as cenas desde o início).

K.S - Mas como fazer, para não falar sobre os sentimentos? É preciso achar alguma ação, que leve ao estado de ânimo necessário. Vocês não podem entender como sua mãe recebeu a morte do seu pai e como logo se casou com outro. Tentem entender e confirmar o que é esse Fantasma do pai; esforcem-se para saber do pai tudo aquilo que ele lhes pode falar.

Você lembra da cena do juramento? Hamlet, precisa reconstruir a vida na terra, então isso será bom para ele, e promete morrer em luta por isso. De qualquer forma, Hamlet morre sem realizar tudo. Esse é o conhecimento da existência. Esforçar-se para entender tudo, fazer tudo para saber a verdade. Há o encontro com Horácio. Você 
precisa de Horácio. Você deve incluí-lo numa corrente de circunstâncias, ele deve ajudá-lo.

Rozanova - Eu quero saber dele... entender o que ele sabe.

K.S. - Você não pode falar tudo a ele, apesar dele saber muito, porque ele viu o Fantasma. Ele, querendo ou não, participou de seu segredo. Em qualquer caso, Horácio é uma figura muito importante para vocês.

Após o encontro com o Fantasma do pai vocês já vão reagir em relação a tudo. Falar ao Fantasma como vocês falam é impossível.

Rozanova - Nós fomos ao encontro de um homem vivo.

K.S. - Se este Fantasma falasse tão alto, tudo seria muito mais fácil para vocês. Caso contrário, torna-se muito difícil saber algo sobre ele. Mas com vocês tudo não passa de conversas francas apenas. Isso é claro, depende da atuação do Fantasma, e da de vocês também.

Rozanova - A saída na praça. O senhor não entendeu nada aqui?

K.S. - Entendi pouco; isso não foi uma conversa com o Fantasma, mas uma conversa com um bravo soldado.

Fromgolhd - Como achar a leveza, como se transformar em Fantasma?

K.S. - O Fantasma é algo instável, vacilante, o Fantasma se esconde. Aproximarse dele não é possível.

Rozanova - Nós gostaríamos muito que o senhor dissesse do que gostou e do que não gostou naquilo que o senhor viu.

K.S. - Quando vocês agiram verdadeiramente, foi bom. Por exemplo, no encontro com a mãe, a rainha e o rei Cláudio, depois no momento da espera pelo Fantasma. Aqui houve momentos vivos.

Observe se eu verei desse príncipe, esquecido das regras de bom-tom, a etiqueta. Olhando para longe... (mostra) Achar a verdade... Analisar o que aconteceu... Como uma tarefa matemática inculcada em si - como isso podia acontecer. (mostra) Anda, novamente volta, “Deus meu, Horácio!”. Joga-se para ele. “Mas como, como tu estás?” E, de repente, a novidade sobre o Fantasma do pai. É necessário entender essa notícia. Isso é clareza da atenção. Aqui não há o que atuar. Se o Fantasma é realmente o rei, seu pai, isso significa, que, para além do grande mundo, em você começa a surgir algo novo...

Rozanova - Isso quer dizer, falar sussurrando? 
K.S. - Falar idealmente em sussurro é terrivelmente difícil. Aqui se trata da ação mais simples - conhecer!

Rozanova - Eu todo tempo procuro, procuro e de nenhum jeito consigo encontrar o que necessito. Ou eu faço uma coisa, ou faço outra. O pai fala que é necessário vingar-se pelo triste assassinato.

K.S. - Mas essa tarefa não pode ser resolvida logo.

Rozanova - Mas ele me comunica que é necessário vingar-se pelo triste assassinato.

K.S. - No início é necessário somente entender.

Rozanova - Eu entendo que é necessário não fazer nada, e assim mesmo faço algo, obrigatoriamente.

K.S. - Isso significa o não-lógico. A não-lógica sempre vai para o ofício.

Hamlet está inteiramente orientado para uma finalidade. Ele olha tudo, observa a vida, penetra na sua essência.

Rozanova - Mas que diferença há entre antes do aparecimento do Fantasma e depois do seu aparecimento?

K.S.- Antes do Fantasma, havia "Vossa excelência”, mas depois do Fantasma... (mostra). Se lá é assim e aqui é isso, para que viver no mundo... (mostra).

Rozanova - Quando o Fantasma vai embora, retira-se, o senhor também não nos entendeu totalmente?

K.S. - Não muito.

Rozanova - Eu entendo, que havia uma pessoa e não há mais essa pessoa. Pois ele esteve aqui, falou comigo e - desapareceu. É necessário realizar isso.

K.S. - Quais são as palavras aqui? Com quem se comunicar? Com Horácio? A quem recorrer? Não, é necessário que seja de outra maneira. É necessário gastar toda a vida para saber a verdade, conhecer o mistério da existência.

Rozanova - Mas em nós houve relação com Horácio, nós somos amigos. Isso chegou ao senhor?

K.S. - Aqui há a mais simples ação (mostra).

Rozanova - Mas quando Horácio me pergunta o que aconteceu, como lhe explicar isso?

K.S. - Você não pode dizer a ele tudo aquilo que seu pai lhe revelou. Isso você não vai falar a ninguém no mundo, e jamais falará sobre isso. Haverá qualquer mentira, mas não dirá a ninguém a verdade. 
Rozanova - Quando Horácio e Marcelo chegam à praça, depois do meu encontro com a Sombra, eu ainda vivo aquele momento. Mas todos exigem explicações sobre o que aconteceu. Eu quero compartilhar com alguém, mas ao mesmo tempo não consigo falar nada a eles.

K.S. - Você não pode falar. Você fala que isso é horrível, mas entrar em detalhes você não tem nenhum direito. Você não pode falar para eles nem sim nem não.

Rozanova - E quando Hamlet fala que pode viver sorrindo, e com um sorriso canalha.

K.S. - Você investigue o que quer dizer observar, penetrar, conhecer... Todas as formas, as nuances do conhecimento, todas as vias para isso. Pode ser que Hamlet interprete o papel de louco. Pode-se explicar assim. Mas a pessoa que descobriu o que descobriu Hamlet não pode ser normal para nós, pessoas simples.

Rozanova - Como nós devemos conduzir o trabalho?

K.S. - Esse é um trabalho muito importante e é necessário, junto com todos os grupos, realizar trabalho semelhante. Vai haver As Três Irmãs, o que é maravilhoso, mas e Shakespeare como fica? Esse trabalho deve continuar sempre. Mas ao final vocês devem permitir que representem Hamlet. Para vocês esse é um trabalho muito grande: vocês devem colocar a voz, e nas suas pernas não devem vestir malhas. Exercitem-se em casa, aprendam a fazer exercícios com a postura das pernas.

(Os estudantes fazem exercícios)

K.S. - Quando você dança, como coloca as pernas? Por exemplo, no século XVIII como você pode representar com tais pernas? Você deve ter uma postura leve, é necessário girar as pernas a partir dos quadris.

Rozanova - Mas fale o que foi ruim. Nem que sejam palavras gerais.

K.S. - Houve alguma coisa boa, mas houve pouca ação. Quando você começa a agir, cai na ênfase. Ação da palavra não houve; quando, casualmente, aparecia, foi muito agradável. É necessário que vocês, através desse trabalho, entendam, o quanto é importante a ação na palavra. Se vocês agirem sem ritmo, vai ser ridículo. É necessário representar Shakespeare com total simplicidade; se vocês fazem um gesto, é preciso levá-lo, obrigatoriamente, até o fim.

Krasnuchkina - Eu queria perguntar sobre Ofélia.

K.S. - Antes de tudo, ache-se no papel, então o papel surgirá em você. Ela fala baixo. Falar baixo significa estar confusa. Além disso, você não agiu, portanto não 
entendemos nada. E disso realmente não necessitamos. Qual Ofélia, ainda é cedo para falar. Mostre quem é você no papel, então dirão a você como deve ser sua Ofélia.

Piatnitskaia - Eu como rainha não consigo nada. Ou sou orgulhosa demais, ou arrogante demais.

K.S. - Rainha - isso é rainha. A rainha deve ser proclamada no mundo todo. No início é necessário conseguir que cada palavra da rainha seja fundamental para você. Você teme as palavras. Quando começa a falar baixo, isso quer dizer - a atriz não está no papel.

Piatnitskaia - Eu amo o filho e o marido, pois as pessoas estão sentadas ao redor. Meu marido hoje apresenta-se pela primeira vez à esplendida sociedade.

K.S. - Essa é uma recepção comum. Mandam o mensageiro.

Martianov - Eu todo o tempo temia essa cena.

K.S. - Mas você está no trono, e isso já é esplendido. Trata-se de um ato político de importância muito grande; pois pode mandar agora o mensageiro de seu país a outro país. Você não pode sentar no trono e palitar os dentes. Mas você tem muito pouca oficialidade; ela deverá ser muito maior. Você pensou não sobre o que fazer, mas como fazer.

Martianov - O senhor falou, que se o ator fala baixo, significa que tem medo. Mas veja, isso pode ser outra coisa. Eu agora falei alto.

K.S. - Você ainda não possui fé nas palavras.

Martianov - Falando francamente eu tenho medo de uma idéia lindamente construída. Ela não me caracteriza muito, e eu temo, como se não conseguisse comicidade.

K.S. - Por que não falar belas idéias? Isso, claro, é necessário saber fazer.

(Aos estudantes) A vossa principal tarefa: técnica e técnica. Sacrifiquem alguns anos da sua vida para estudar a técnica do ator, porque depois não vão ter mais tempo. Hoje vocês não têm uma postura acabada, a palavra não vai com a língua. Aquilo de verdadeiro que vocês agora adquirirem, evitará que caiam no ofício. Por isso se agarrem nisso.

Mas há entre vocês os que dizem: "nós já somos atores, precisamos atuar". Todos imaginam que podem ser artistas, atuar, cantar, e todos vão ser artistas, no teatro. Mas perecem. A arte é muito difícil. Por que difícil? Porque exige trabalho diário, sistemático e constante. 


\section{CAPÍTULO III}

\section{APROXIMAÇÃO À ANÁLISE DE ALGUNS ASPECTOS DA IMAGEM ARTÍSTICA NA NOVELA “KROTKAIA” (A DÓCIL), DE FIÓDOR M. DOSTOIÉVSKI}

Na criação de Dostoiévski existe um único tema - o trágico destino do homem, a liberdade do destino do homem. O amor é somente um dos momentos nesse destino. ${ }^{177}$

\section{IMPRESSÕES SOBRE A NOVELA A DÓCIL}

A novela A Dócil, editada na revista mensal Diário de um Escritor em novembro de 1876, foi considerada pelos críticos uma das obras-primas curtas do último período de Dostoiévski, de 1872 a 1881. O texto trata do monólogo interior de um homem, diante do esquife de sua mulher morta, que se jogara de uma janela agarrada a um ícone. O contexto, na narrativa, é evidenciado pela temática feminina, que na época suscitava fortes polêmicas no meio intelectual russo, veiculadas nessa mesma revista, relativamente à submissão da mulher, à igualdade moral e intelectual entre homens e mulheres.

Esse é um dos problemas externos que atuam na construção da narrativa de $A$ Dócil, na qual o autor mostra as conseqüências dessa mentalidade de poder nas relações conjugais através dos motivos e atitudes do herói para com a mulher, dando ênfase, sobretudo à impossibilidade de dominação interna do ser humano. O nome da novela já indica a conotação da submissão da heroína, que soa de certa forma como uma ironia. Sobre isso, Joseph Frank ${ }^{178}$ (1918- ) observa que:

em nenhum outro lugar pode-se mais facilmente do que no Diário acompanhar o processo pelo qual Dostoiévski transformou os faits divers de seu tempo, o relato jornalístico comum de algum evento momentaneamente sensacional, em substância de sua arte. Apenas um mês antes de publicar 'A Tímida' [A Dócil], por exemplo, Dostoiévski escreveu sobre dois suicídios que tinham recentemente chamado sua atenção, sendo um deles o de 'uma jovem costureira que tinha pulado de uma janela segurando uma imagem sagrada em suas mãos' (grifos do original). A versão do jornal atribuía a morte a causas econômicas (...), mas o que evidentemente tocou Dostoiévski

\footnotetext{
${ }^{177}$ BERDIÁEV, N. Mirosozertsánie Dostoiévskovo (O mundo contemplativo de Dostoiévski). Moscou: I. Zakharov, 2001, p.83.

178 Joseph Frank, Professor na Universidade de Stanford, Califórnia, Estados Unidos, e autor de uma biografia em cinco volumes de Dostoiévski.
} 
foi o detalhe do ícone, a combinação do pecado, do desespero com uma devoção tão profunda. 'Essa imagem sagrada em suas mãos é um traço estranho, até hoje inédito num suicídio!', ele escreve. 'Foi um suicídio tímido e humilde'. Este detalhe, claramente, estimulou a imaginação de Dostoiévski e a pôs a trabalhar; o resultado é essa história pungente, que culmina na visão final, desolada, de um mundo totalmente destituído do amor simbolizado pela imagem sagrada. ${ }^{179}$

Vejamos a opinião de Grossman ${ }^{180}$ (1888-1965) sobre a criação dessa obra. Ele esclarece que o projeto da novela iniciou em 1869, quando Dostoiévski planejava criar um conto sobre as divergências e o rompimento familiar, no qual já aparecem as características do marido déspota e da mulher vítima, resultando no assassinato da esposa. O projeto concretiza-se após sete anos, com a criação de A Dócil, num período de muitos suicídios, em que Dostoiévski, além de acompanhar os jornais, investiga o estado psíquico perturbado dessas pessoas. Esse processo de preocupações com o suicídio recebe expressão no artigo Veredicto, publicado no Diário do Escritor. Dostoiévski, diz o crítico, “ficou impressionado com o contraste interior do acontecimento: a aliança extraordinária de desespero e fé, destruição e esperança, morte e amor". ${ }^{181}$ Palavras de Dostoiévski citadas na obra de Grossman:

Essa imagem nas mãos é um traço estranho e desconhecido nos suicidas [...] durante muito tempo não conseguimos deixar de pensar em certas coisas, por mais simples que pareçam, elas como que nos perseguem, e até nos parece então que temos culpa dessas coisas. Essa alma doce e humilde que destruiu a si mesma forçosamente tortura o pensamento. ${ }^{182}$

Ainda de acordo com Grossman, Dostoiévski conservou o plano antigo, “o drama interior” e atribuiu novos traços à heroína criando um desfecho totalmente diferente, que alterou o tom da novela. O antigo projeto do marido tirano e da esposa vítima, conjugado agora ao suicídio da mulher, que se jogara da janela apertando a imagem ao coração consolida-se na narrativa A Dócil. "Dostoiévski abre para si um novo caminho e encontra uma forma 'inédita'. Ele cria uma novela trágica, de inusitada força e de uma verdade insopitável". ${ }^{183}$

\footnotetext{
${ }^{179}$ FRANK, J. Pelo Prisma Russo: Ensaios sobre Literatura e Cultura. São Paulo: Edusp, 1992. pp. 175176.

${ }^{180}$ Leonid P. Grossman, crítico literário russo-soviético, especialista em Dostoiévski.

${ }^{181}$ GROSSMAN, L. Dostoiévski Artista. Rio de Janeiro: Civilização Brasileira, 1967, p. 127.

${ }^{182}$ Ibidem, pp.127-128.

${ }^{183}$ Ibidem, p.124.
} 
Dostoiévski, no prefácio da novela, fala da forma utilizada na narrativa, qualificando-a de monólogo interior, narrativa em primeira pessoa em que o narrador sob estado de choque pelo suicídio da mulher, tenta concentrar seus "pensamentos em um ponto" 184 , que lhe permita fazer uma investigação sobre sua vida pregressa para poder chegar à verdade sobre a tragédia ocorrida. $\mathrm{O}$ autor esclarece que utiliza na narrativa uma técnica semelhante a do estenógrafo, e diz ser isso que constitui o fantástico da novela. O marido fala ora para si mesmo, ora para um interlocutor imaginário, ou ainda para algum juiz, querendo esclarecer para si o trágico acontecimento. Dirigindo-se para um ouvinte invisível, justifica a si e culpa a mulher. Apresenta, em suas “explicações esquisitas”, “rudeza de pensamento” e de “coração”, mas também há “sentimento profundo”. O fantástico da narrativa se dá pela forma empregada, na qual o herói é colocado numa situação limite, em que a tragédia já está consumada. Sobre essa forma de representação diz Bakhtin ${ }^{185}$ (1895-1975) que Dostoiévski "sempre retrata o homem no limiar da última decisão, no momento de crise e reviravolta incompleta" - e não premeditada - “de sua alma”, pois pretende, “descobrir o homem no homem", retratando todas "as profundezas da alma humana”. 186

O monólogo interior possibilita o enfoque do herói no processo de desvelamento da autoconsciência, em que faz uma profunda investigação de sua vida e de sua relação com a mulher. É um discurso direto através do qual a heroína é enfocada sob a perspectiva interior do herói. Encontramos uma analogia com a dramaturgia de Strindberg, referida por Peter Szondi, a “dramaturgia do eu”, do "drama subjetivo”, que "parece coincidir com a teoria do romance psicológico (com a história da evolução da própria alma)" ${ }^{187}$ Diz Grossman que a história narrada sob a ótica da auto-análise do herói que se encontra sob forte conflito psicológico, permite revelar “dois destinos em seu pleno desenvolvimento”. ${ }^{188} \mathrm{E}$ através desse procedimento o discurso se dá de forma direta em que os acontecimentos passados são narrados sob a perspectiva da focalização interna do herói, na medida que ele tenta encontrar uma explicação convincente para si mesmo sobre o ocorrido. O Oficial/Agiota diz: "É ai que

\footnotetext{
${ }^{184}$ DOSTOIÉVSKI, F. M. Krótkaia (A Dócil). Obras Completas, Tomo 10. Leningrado: Naúka, 1982, pp. 378-379.

${ }^{185}$ Mikhail M. Bakhtin, historiador da literatura e filólogo russo-soviético.

${ }^{186}$ BAKHTIN, M. Problemas da Poética de Dostoiévski. $3^{\mathrm{a}}$.ed, Rio de Janeiro: Forense Universitária, 2002, pp.60-61.

${ }^{187}$ SZONDI, P. Teoria do Drama Moderno [1880-1950]. São Paulo: Cosac\&Naify, 2003, p.54.

${ }^{188}$ GROSSMAN, L. Dostoiévski Artista. Rio de Janeiro: Civilização Brasileira, 1967, p.129.
} 
está todo o meu horror, eu entendo tudo!". ${ }^{189}$ O trágico revela-se nele mesmo, no processo de busca, de investigação sobre si mesmo, em sua consciência, resultando aí o tema da novela, ou seja, a verdade. A idéia está nesta busca para decifrar o enigma do suicídio, sendo que a sua revelação eleva o espírito e o coração do herói.

Segundo Grossman, o recurso utilizado na novela testemunha o excelente conhecimento que Dostoiévski possuía deste gênero, como também evidencia o lugar de destaque que o autor dava a arte da história curta, pois conhecia desde criança a coletânea oriental de novelas fantásticas, os contos de Karamzin (1766-1826), Gogol, Puchkin entre muitos outros.

Mas por maior que fosse a sua erudição quanto ao gênero, tinha conhecimento seguro de que o principal problema do novelista consiste em despertar, de chofre e com habilidade, o interesse pelas personagens e pela ação. ${ }^{190}$

Diz que Dostoiévski apresentou um acontecimento incomum em que o conteúdo tenso da novela “encerra a sua ação no círculo único da catástrofe interior»191 , começando a narrativa pelo desfecho trágico.

Embora o monólogo interno, com caráter trágico, seja dominante, constata-se uma multiplicidade de gêneros no interior do texto que coexistem em diferentes níveis. Verifica-se a abrangência "mitológica” na construção do enredo e na composição das personagens com os seus conflitos humanos universais. Além do nível mitológico que revela o eterno, o vertical, aparecem os níveis: familiar, social e psicológico. O plano cósmico que diz respeito à natureza do homem, à morte e à liberdade, tem forte presença na novela.

A novela A Dócil está estruturada em dois capítulos. O primeiro contém seis partes intituladas: Quem era eu e quem era ela; Pedido de casamento; O mais nobre dos homens, mas nem eu mesmo acredito; Planos e mais planos; A Dócil se rebela; Uma recordação terrível.

Na nomeação da primeira parte, Quem era eu e quem era ela, está implícita a apresentação das personagens, que corresponde à exposição. A Dócil faz uma série de visitas à casa de penhores com o objetivo de empenhar objetos para pagar anúncios de

\footnotetext{
${ }^{189}$ DOSTOIÉVSKI, F. M. Krótkaia (A Dócil). Obras Completas, Tomo 10. Leningrado: Naúka, 1982, p.380.

${ }_{190}$ GROSSMAN, L. Dostoiévski Artista. Rio de Janeiro: Civilização Brasileira, 1967, p.130.

${ }^{191}$ Ibidem, p.129.
} 
jornal, solicitando emprego. Já na segunda visita surge o interesse do Oficial/Agiota em relação à adolescente pobre e órfã. Cada visita apresenta um novo elemento, no qual Ele submete a Dócil à prova. Esse fragmento finaliza quando Ela traz a antiga imagem de família para vender. Grossman destaca a importância do último objeto da Dócil que vai parar na casa de penhores, para a construção da novela: “a antiga imagem de família, com casula de prata, que aparecerá no final do drama, e que terá um papel decisivo na elaboração do projeto de Dostoiévski”. 192

O próximo fragmento, intitulado Pedido de casamento, é o acontecimento que dá início à intriga. Nele, o leitor obtém mais informações sobre a heroína e o herói. Ela perdeu seus pais aos 12 anos, é escrava das tias, que a deixam sem comer e pretendem vendê-la para um viúvo vendeiro. O centro de interesse dessa situação é o próprio pedido de casamento em que o Oficial/Agiota aparece como o salvador da heroína. O pedido de casamento é aceito, dando início à vida conjugal, que aparece no desenvolvimento das próximas quatro partes, nas quais são revelados os planos secretos do marido, que esfriam o entusiasmo e os sentimentos da jovem esposa em relação ao amor.

Esse primeiro capítulo culmina com a tentativa de assassinato do marido pela esposa. O marido declara que "o casamento estava desfeito 'ela foi vencida, mas não perdoada”. ${ }^{193}$ Sobre esse desenrolar da novela Grossman afirma que Dostoiévski construiu “magistralmente o ponto central da narrativa. É a virada inesperada $e$ surpreendente da intriga, que marca a crise mais profunda de toda a ação interior". ${ }^{194}$

O segundo capítulo contém quatro partes: Entendo muito bem; Um sonho de orgulho; De repente a venda cai; Atrasei-me não mais que cinco minutos.

Nesse capítulo, após a tentativa de assassinato, uma cama de ferro e um biombo separam o quarto de dormir do casal. A heroína atormentada pelo acontecimento é levada à doença, que a deixa em estado de inconsciência. Quando a Dócil recupera-se, o herói continua em seu enigma e Ela, em seu canto, silenciosa.

A lentidão instalada na narrativa após o acontecimento "homicídio" é quebrada com o fragmento “De repente a venda caiu”, quando o herói é surpreendido pela canção de sua esposa, que lhe suscita a indagação do lugar que Ele ocupa em seu

\footnotetext{
192 GROSSMAN, L. Dostoiévski Artista. Rio de Janeiro: Civilização Brasileira, 1967, p.131.

193 DOSTOIÉVSKI, F. M. Krótkaia (A Dócil). Obras Completas, Tomo 10. Leningrado: Naúka, 1982, Cap. II, $6^{\text {a. }}$ parte, p.403.

${ }^{194}$ GROSSMAN, L. Dostoiévski Artista. Rio de Janeiro: Civilização Brasileira, 1967, p.133.
} 
coração. A partir dessa revelação o herói precipita-se desesperado, declara o seu amor, confessa seu passado e faz planos de uma vida em comum feliz.

Após Ela ter confessado o seu crime e prometer-lhe fidelidade, surpreendentemente acontece nova virada: a heroína comete suicídio, o que constitui o ápice da história. No epílogo, Atrasei-me não mais que cinco minutos, com a tragédia já consumada, restam as infinitas indagações pelas razões de tal desfecho trágico, que dá início à novela e, conforme Grossman, à “construção anelar da novela”.

É a 'novela-espiral' (segundo o conhecido termo de Paul Heyse). As curvas afastam-se cada vez mais do ponto de partida, mas a mola distendida se contrai de repente, na direção do centro inicial, de modo que o desfecho, o fim da espiral, se dispõe justamente por cima de seu inicio: a introdução ao relato. ${ }^{195}$

Tudo o que é informado ao leitor sobre a heroína e demais personagens referidas na história é através do narrador, a personagem Oficial/Agiota. O diálogo entre ambos, em que aparece como projeção que faz dela, acontece pela primeira vez no final da primeira parte, em que Ela empenha a imagem de Nossa Senhora, quando Ele cita Goethe e Ela diz: "Que pensamento é esse? De onde vem? Eu já ouvi essa idéia em algum lugar...”.196 A próxima intervenção direta ocorre no Pedido de casamento, gerando uma expectativa por parte do herói, que pergunta: "Pois então, minha senhora?” Ela responde: “Espere, estou pensando". ${ }^{197}$ Na parte na qual a Dócil se rebela, o diálogo se apresenta de forma densa, com interrogações e explicações em que as personagens são colocadas em confronto:

Quer dizer que é verdade que o senhor foi expulso do regimento porque não teve coragem de se bater num duelo? perguntou ela, de repente, à queima-roupa [...] É verdade [...] Foi expulso como um covarde? [...] O senhor, porém, não me falou nada disso antes do casamento. $^{198}$

O diálogo ainda aparece no enfrentamento entre o herói e o oficial-inimigo e em raros informes necessários entre a Dócil, o Agiota/Oficial e a criada Lukéria.

\footnotetext{
${ }^{195}$ GROSSMAN, L. Dostoiévski Artista. Rio de Janeiro: Civilização Brasileira, 1967, p 129.

196 DOSTOIÉVSKI, F. M. Krótkaia (A Dócil). Obras Completas, Tomo 10. Leningrado: Naúka, 1982, Cap. I, $1^{\text {a. }}$ parte, p. 384.

197 Ibidem, Cap. I, $2^{\text {a. }}$ parte, p.388.

198 Ibidem, Cap. I, $5^{\mathrm{a}}$ parte, p.397.
} 
$\operatorname{Arban}^{199}$ (1903-1991) enfatiza um dos recursos utilizados por Dostoiévski para agarrar o leitor, para tomá-lo como testemunha, como cúmplice: a palavra "Senhores". E considera essa atitude do herói dúbia, uma fuga para o fundo de si mesmo e enfrentamento com o outro, uma recusa e possessão do outro, diferente dele, o qual ele tem que convencer, que agarrar: "Deixa o mundo para perseguir a si mesmo no fundo de si; depois deixar-se, para apossar-se do mundo". ${ }^{200}$ Ao mapear o texto sob essa perspectiva, do chamamento do leitor, enquanto interlocutor, a encontramos mais de trinta vezes só na primeira parte desta novela. Esse recurso aparece de diversas formas, além da palavra "Senhores”, por exemplo: "Reparem...”, “Eis o que aconteceu”, "Notem tudo isso", "Queiram notar isso também”, “Os senhores perguntam”, "Eu Ihes respondo”, “Esperem...” “Não, ouçam”, “Então, reparem”, “Hão de concordar”, “Acreditem”, “Permitam-me, Senhores”, "Vejam”, “Pasmem os Senhores”, “Vão rir de minha inquietação”, “E olha”, “Lembram-se”, “Os senhores acham...”.

A novela $A$ Dócil possui uma única personagem que manifesta diretamente suas opiniões, no presente, sobre as outras personagens e sobre si mesma. Ela expressa em diferentes planos a temática do poder, do domínio, do orgulho, da mesquinhez, do egoísmo, refletindo as muitas faces do problema, através da penetração cruel sobre si mesma, aprofundando-se cada vez mais nas diferentes camadas ocultas da personagem.

O mosaico de revelações, confissões e descobertas da personagem é conduzido pela idéia principal, que é a busca da verdade. O esclarecimento dessa idéia é o eixo principal que dá unidade à narrativa, pois monopoliza e ajusta as diferentes opiniões expressas pela personagem sobre si, sobre a heroína, e sobre os outros, chegando a um resultado mais ou menos satisfatório das razões, justificativas e explicações, que o ajudam na elucidação do acontecimento trágico.

Na novela, o método de se colocar em julgamento diante de si mesmo e dos outros gera ironia e suaviza o trágico da situação, conferindo um caráter de distanciamento crítico e, às vezes, cômico. Consideramos que muitas vezes, esse recurso soa como a manifestação do próprio autor, entendida como ironia, erudição, indignação, crítica à personagem. Seguem-se exemplos:

\footnotetext{
${ }^{199}$ Dominique Arban, escritora e especialista em Dostoiévski.

${ }^{200}$ ARBAN, D. Dostoiévski. Rio de Janeiro: José Olympio, 1989, pp.52-53.
} 
Oh, que sujeito inconveniente, infame! ${ }^{201}$; Realmente pode acontecer que uma pessoa dormindo profundamente abra os olhos e até mesmo erga por um segundo a cabeça e olhe o ambiente, porém depois de um instante, sem consciência deite a cabeça no travesseiro e durma, não lembrando mais de nada. ${ }^{202}$

Meletínski $^{203}$ (1918-2005) fala do elemento demoníaco na obra de Dostoiévski como um novo caráter de manifestação do caos:

[...] nós nos deparamos não só com o reflexo da humilhação social como também com a alienação da alma do herói. [...] Os próprios conflitos sociais, a luta do bem e do mal, e na perspectiva da obra mais tardia de Dostoiévski, a luta do cosmos contra o caos transportam-se para a profundeza da alma humana, dando origem ao 'subsolo' psicológico. ${ }^{204}$

A barbárie que se manifesta na personalidade do herói é justificada, em parte, pela sua vida pregressa, pelas injustiças e humilhações sofridas no passado, sendo que suas escolhas são uma forma de vingança por todo o mal que sofreu da própria sociedade, como também uma forma de autoflagelação. A casa de penhora faz parte dessa vingança e é justificada como um meio de preparar o futuro, de alcançar os objetivos elevados, que aspiram ao bem, à felicidade. A atividade de agiotagem tem um caráter dúbio: é marginal, mas permitida pela sociedade. A Dócil diz ao marido, em tom debochado: “Ah agora o senhor é um figurão - um financista!”, 205

O aspecto demoníaco é também manifesto na escolha, na aplicação de um bem recebido, a herança, para a multiplicação rápida do dinheiro através de um meio, “o caixa”, questionável moralmente. Essa escolha, além de constituir uma vingança contra as injustiças recebidas, o possibilita a exercer a vontade de poder, a dominar, a manipular outras pessoas, vítimas de circunstâncias adversas. O orgulho, o egoísmo, a mesquinhez são características de sua personalidade que geram sentimentos de vingança e ressentimento e que o levam a ações destrutivas, reveladoras do caos da alma do herói.

\footnotetext{
${ }^{201}$ DOSTOIÉVSKI, F. M. Krótkaia (A Dócil). Obras Completas, Tomo 10. Leningrado: Naúka, 1982, 1982, Cap. I, 2 2a parte, p. 388.

${ }^{202}$ DOSTOIÉVSKI, F. M. Krótkaia (A Dócil). Obras Completas, Tomo 10. Leningrado: Naúka, 1982, Cap. I, 6aparte, p. 401.

${ }^{203}$ Eleazar M. Meletínski, doutor em ciências filológicas, historiador da cultura e do folclore, estudioso da literatura comparada ocidental e oriental, do mito, da poética histórica, dos arquétipos e de seus reflexos na literatura.

${ }^{204}$ MELETÍNSKI, E. M. Os Arquétipos Literários. São Paulo:Ateliê Editora, 1998, p.210.

${ }^{205}$ DOSTOIÉVSKI, F. M. Krótkaia (A Dócil). Obras Completas, Tomo 10. Leningrado: Naúka, 1982, Cap. I, $5^{\text {a. }}$ parte, p.398.
} 
As forças do cosmos e do caos coexistem nesta novela. Essa evidência pode ser constatada quando a Dócil vai empenhar o último objeto que ainda lhe resta, o ícone de Nossa Senhora. Nessa cena aparece explicitamente o confronto do sagrado e do demoníaco, o ícone e a referência a Mefistófeles.

Em Dostoiévski, o bem e o mal estão sempre presentes na alma humana e em constante conflito. O bem, na personagem do Oficial/Agiota aparece relacionado ao sentimento, às questões do coração, à intuição e ao sofrimento. No próprio ato de desvelamento do herói, o mergulho na profundidade de sua alma manifesta o bem, a busca da verdade, do cosmos, da harmonia. Na novela, só no ponto mais expressivo da dor do herói, no seu ápice, é que ouvimos a palavra “coração” pronunciada inúmeras vezes. Achimbáieva, no seu artigo O coração na obra de Dostoiévski e antropologia bíblica, destaca, sobretudo, a palavra “coração” na obra de Dostoiévski. Diz que o centro de atenção de Dostoiévski é a imagem do coração. O coração é o centro espiritual da existência física do ser humano e tem suas fontes em Karamzin, na Bíblia e no Evangelho. “Aplica-te com todo o cuidado possível à guarda do teu coração, porque dele é que procede a vida”. ${ }^{206}$

\section{A IMAGEM ARTÍSTICA DA NOVELA A DÓCIL}

Para nos aproximarmos a uma análise de alguns aspectos da imagem artística na novela A Dócil, dividimos o enredo em três partes e as nomeamos segundo os principais acontecimentos que ocorrem em cada parte: primeira parte-conhecimento, sedução e conquista; segunda parte: submissão, dominação, transgressão e rebeldia; terceira parte: punição, castigo, declaração, confissão e morte.

Primeira parte: conhecimento, sedução e conquista.

É formada por situações nas quais nos é dado a conhecer "quem era Ele e quem era Ela” e se estende até o casamento. As situações que compõem o prólogo se constituem das várias vindas da Dócil à casa de penhores com o objetivo de empenhar objetos, somadas às situações de investigação que o penhorista realiza para colher informações sobre a heroína. A introdução tem como ápice o empenho da imagem sagrada da Virgem com o Menino, lembrança dos pais, que morreram.

\footnotetext{
${ }^{206}$ ACHIMBÁIEVA, N.T. Sérdtse v proizvedéniakh Dostoiévskovo i bibléiskaia antropológia (O coração na obra de Dostoiévski e antropologia bíblica). In. Dostoiévskii v kontsé $X X$ véka (Dostoiévski no final do século XX). Moscou: Klassika Plius, 1996, p.379.
} 
Essa parte da narrativa enfoca os procedimentos do herói para seduzir a Dócil e o suborno que comete para colher informações sobre Ela. Por parte da heroína, percebe-se uma espécie de desafio às regras vigentes, pois, ao freqüentar um espaço não recomendável para senhoritas de sua idade, está quebrando um limite de conveniência social estabelecido. Ele, por ocasião das visitas da heroína ao caixa, submete-a a inúmeras provas, observando suas reações como se fosse um cientista diante de seu objeto de estudo.

Verifica-se, através dessas pequenas crueldades com as quais coloca a heroína em constrangimento, o tipo de mentalidade do herói. Esses episódios culminam com o empenho da imagem sagrada, último objeto que resta à heroína, quando Ele, inesperadamente, apresenta-se a Ela como Mefistófeles, que se oferece a Fausto e num arroubo de teatralidade diz: “ $\mathrm{Eu}$, eu sou aquela parte do todo que quer fazer o mal, mas que cria o bem”. ${ }^{207}$ Aqui há um confronto entre o sagrado e o demoníaco, que sofre uma inversão pela astúcia do herói. Nesse confronto, o herói consegue se elevar aos olhos da Dócil e lhe despertar o interesse por ser percebido como homem culto, por citar Goethe. Essa é a resposta que Ele precisa para sua auto-afirmação, ou seja, chamar a atenção sobre si e fazer com que Ela o redimensione para além da profissão que exerce, quebrando dessa forma os limites que os separam.

Eleva-se, desta forma, perante os olhos dela como um homem superior. Diz Ele: “Acertei em cheio no que lhe agrada” e "Ela queria dizer eu não sabia que o senhor era um homem culto”. Nessa mesma situação é também estabelecida uma relativização entre o bem e o mal: "Eu bem sei, eu além do mal não faço nada, sabemos muito bem um agiota será sempre um agiota”. Ela, na qual domina o sentimento de compaixão e bondade, responde: “Mas eu não queria dizer nada disso, sempre é possível se fazer o bem em qualquer situação, sobretudo em qualquer situação". 208

Ele, após ter concluído as investigações sobre Ela, já não tem dúvida de seu poder e a vê como sua, pedindo-a em casamento. As peculiaridades inusitadas indicativas do temperamento da heroína o desafiam e estimulam o seu poder - o rubor, os olhos azuis, grandes e pensativos, que, quando é provocada, pegam fogo. $\mathrm{O}$ alto e o baixo são aqui estabelecidos como: culto-elevado, jovem, pura, calada, boa, tímida, impulsiva, temperamental / agiota, pobre, órfã.

\footnotetext{
${ }^{207}$ DOSTOIÉVSKI, F. M. Krótkaia (A Dócil). Obras Completas, Tomo 10. Leningrado: Naúka, 1982, Cap. I, $1^{\mathrm{a}}$ parte, p.384.

${ }^{208}$ Ibidem, Cap. I, $1^{\mathrm{a}}$ parte, p.384.
} 
O pedido de casamento é feito no portão, que, como sabemos, é um arquétipo de passagem, é uma fronteira, um limite social e de geração existente entre ambos: Ela, plebéia, Ele, nobre, Ela com 15 anos, Ele com 41. Enquanto espera por Ela parado no portão, Ele diz para si mesmo já não ter medo de nada e afirma suas convicções sobre sua superioridade em relação ao rival, o vendeiro, que se encontra no interior da casa da Dócil. Ela está na lama, e Ele a retira dessa lama e das garras do vendeiro e das tias, que a submetem à condição de escrava e, enquanto está à espera do "sim”, pensa: "você é alto, bem-apessoado, nobre de origem, você em si não é nada mau”. ${ }^{209}$ Ele dimensiona a situação, para si mesmo, e afirma surgir como de um mundo superior, salvando-a do domínio e das garras do comerciante gordo, viúvo, velho e bêbado, que tem três filhos e que já “matou duas mulheres”. 210

A criada Lukéria, depois do pedido lhe diz: “E o enxoval a menina não tem nada como é que ela vai se casar". ${ }^{211}$ A Dócil afirma que não precisa de nada mas Ele declara que atribui grande importância às roupas brancas e que Ele mesmo lhe dará o enxoval. Lukéria joga-se a seus pés: “O senhor é um salvador, caiu do céu, obrigada por estar levando a minha querida menina”. ${ }^{212}$ Assim, ele se apresenta diante da heroína personificando o herói positivo, imagem do príncipe dos contos de fada.

Nessa primeira parte, os arquétipos, elevados a símbolos, presentes são: as inúmeras provas a que submete a heroína, a Imagem Sagrada, Mefistófeles, o portão, a lama, as roupas brancas, as ações e atitudes do herói e a condição da heroína, pobre, órfã e escrava que está a venda.

A composição é criada sob a perspectiva das oposições, dos contrastes que se estabelecem entre o herói e a heroína, que alcançam dimensão mitológica, e se dão entre alto/baixo e denotam níveis sociais e de valor, ou seja, qualidades positivas/negativas: Ele - culto, nobre, alto, oficial, educado, bem-apessoado, benfeitor, generoso / meiaidade, agiota, egoísta, mesquinho, orgulhoso, pragmático, calculista, utilitarista. Ela jovem, pura, ingênua, boa, calada, tímida, humilde, magnânima, romântica, sonhadora, sentimental, educada, instruída, generosa, idealista, impetuosa, temperamental, orgulhosa/, pobre, órfã, escrava.

\footnotetext{
${ }^{209}$ DOSTOIÉVSKI, F. M. Krótkaia (A Dócil). Obras Completas, Tomo 10. Leningrado: Naúka, 1982, Cap. I, $1^{\mathrm{a}}$ parte, p.388.

${ }^{210}$ Ibidem, Cap. I, $2^{\mathrm{a}}$ parte, p.386.

${ }^{211}$ Ibidem, Cap. I, $3^{\mathrm{a}}$ parte, p.389.

${ }^{212}$ Ibidem, Cap. I, $2^{\mathrm{a}}$ parte, p.388.
} 
O enredo, neste início, assume o caráter de romance de aventura, o herói nos revelando como conheceu e conquistou a Dócil, como a submeteu a diferentes provas, os obstáculos que enfrentou e venceu, as investigações e, enfim, culmina com o casamento. Percebemos características semelhantes do “espaço pontuado”, proveniente do folclore, da novela picaresca, em que o herói experimenta algumas aventuras, nos segmentos dos episódios que recebem esse significado pelas ações do herói.

Segunda parte: submissão, dominação, transgressão e rebeldia.

Começa a vida em comum do casal: introduzindo a Dócil na perigosa atividade profissional do marido, que a ensina a usar uma arma, a discordância entre ambos na avaliação dos objetos, os arroubos e o silêncio. Ele não a reconhece como parceira igual na relação e na atividade que exerce. Ela ocupa uma condição subalterna, de escrava do marido, não tem voz nem autonomia para decidir sobre a avaliação dos objetos. Diz ele: “Aqui mando eu e tenho o direito de ver a vida com os meus olhos". ${ }^{213}$ Algumas características do caráter da heroína, como impetuosa, orgulhosa, temperamental, sofrem uma inversão no decorrer da história: se antes elas constituíam estímulos para o herói, agora se tornam obstáculos aos seus objetivos de poder e domínio. Já no início, o herói sublinha a diferença entre ambos: “Ela viu num instante que nós somos diferentes e que eu, que eu sou um enigma". 214

Dostoiévski faz uma clara alusão à impossibilidade de uma mútua felicidade quando dominam idéias tão contraditórias entre o casal. O conflito agora se estabelece claramente entre dois pontos de vista, o confronto entre duas visões de mundo. As visões e mentalidades diferentes do herói e da heroína determinam fronteiras definidas e estabelecidas entre cima/baixo, o material/espiritual, horizontal/vertical. Ela, como já mencionamos, apresenta-se com características positivas, plena de idealização, porém orgulhosa e rebelde. Ele está imbuído de uma idéia fixa: acumular dinheiro, prioridade que exclui a relação afetiva. Antes quer respeito e valorização e, para isso, impõe distância e esfriamento do entusiasmo juvenil, opondo-se à aproximação. Ele rejeita a expressão dos sentimentos, esconde-os até de si, porque antes quer moldar, dominar e “infundir grandeza no coração, nos olhos do coração”. 215

Além do que, a caixa de penhores constitui obstáculo para a transparência na relação do casal. Para ele, está em primeiro lugar a realização material, o

${ }^{213}$ DOSTOIÉVSKI, F. M. Krótkaia (A Dócil). Obras Completas, Tomo 10. Leningrado: Naúka, 1982, Cap. I, $5^{\mathrm{a}}$ parte, p.395.

${ }^{214}$ Ibidem, Cap. I, $3^{\mathrm{a}}$ parte, p.390.

${ }^{215}$ Ibidem, Cap. I, $3^{\mathrm{a}}$ parte, p.390. 
reconhecimento e, depois, o amor. As desavenças, as diferenças, a severidade, o enigma, o dinheiro, a vida sob cálculo matemático, as intrigas, a mesquinhez, a verdade sobre o passado, a mentira, a revolta, a desconfiança sobre suposta traição, a recusa ao duelo com o rival levam ao extremo a heroína, que tenta eliminar o herói.

As desavenças espirituais, materiais, familiares e afetivas levam ao silêncio: “Aos enlevos eu respondia com o silêncio". ${ }^{216}$ Interrompida a comunicação, surgem as desconfianças e suspeitas. O diálogo suspenso começa a gerar a intolerância, e as relações ficam cada vez mais extremas e agudas. Vemos o isolamento de dois seres que vivem na mesma casa, unidos pelo matrimônio, mas que resolveram ficar calados. As fronteiras, os paroxismos entre ambos estabelecem-se em níveis multiplicadores.

Ela começa a dar ouvidos aos mexericos e intrigas de alguns freqüentadores da casa de penhores. Rebela-se, sai de casa, rompe o pacto, quebra os limites do acordo nupcial: não ir a lugar nenhum sem o marido. A Dócil torna-se intolerante, impetuosa e transforma-se em fera. Rebela-se, "busca a desordem", vira pelo avesso. A irracionalidade a domina, a pressão sobre ela a leva a revelar um lado de si mesma irracional, contrariando até mesmo o seu caráter. A heroína sai em busca de informações, quer saber toda a verdade sobre o passado oculto do marido. Descobre que o Oficial/Agiota foi expulso do regimento por covardia. Quer confirmação e, para isso, marca um encontro com um antigo colega de regimento do marido. O inimigo de outrora, responsável pela expulsão do herói do regimento, volta e, como um fantasma do passado, encontra o solo propício para semear a discórdia. Ela rompe a fronteira da conveniência, para uma mulher casada, e marca um encontro com o inimigo do marido, a fim de esclarecer os boatos. Ele a espia, num quarto ao lado, espremido, reflete sobre sua situação: “atrás de uma porta entreaberta, para ouvir o primeiro rendez-vous a sós da minha mulher com aquela besta do Iefímovitch". 217

Nesse espaço minúsculo, “impuro”, Ele a descobre em toda a sua grandeza, e em seu poder de argumentação, “onde é que essa monossilábica aprendeu tudo isso?”. ${ }^{218}$ Ela revela-se como ideal de pureza, grandeza e, ao mesmo tempo, de astúcia e inteligência jamais imaginado por Ele. Nesse espaço fechado, secreto, considerado impróprio para uma jovem e respeitável mulher casada, Ela trava um duelo com o inimigo do marido e o vence, não com o poder de uma arma, mas com o poder da

${ }^{216}$ DOSTOIÉVSKI, F. M. Krótkaia (A Dócil). Obras Completas, Tomo 10. Leningrado: Naúka, 1982, Cap. I, $3^{\mathrm{a}}$ parte, p.390.

${ }^{217}$ Ibidem, Cap. I, $5^{\mathrm{a}}$ parte, p.396.

${ }^{218}$ Ibidem, Cap. I, $5^{\mathrm{a}}$ parte, p.398. 
palavra, pela argumentação, inteligência e astúcia, exatamente o que lhe era negado no espaço familiar.

Estabelece-se a inversão no espaço de comunicação, que deveria ser no seio da família, lugar ideal para o diálogo e a cumplicidade, Ela, aqui, revela toda sua capacidade e potencialidade sufocadas. Inverte-se dessa forma o significado do espaço, da situação em que Ele a submetia e da representação que tinha sobre Ela. O herói penetra no ambiente com uma arma e salva a mulher, ingênua e pura, das garras do inimigo, qualificando-o “de uma besta mundana, pervertida e embotada, com uma alma de réptil". ${ }^{219}$ Sente-se vitorioso pela façanha, apesar de ter-se revelado o contrário, novamente um covarde, pois, se encontrando já na soleira da porta, Iefímovitch o desafia novamente ao duelo. Uma fronteira que o herói se negou ultrapassar, porém a ultrapassa quando a mulher tenta matá-lo.

Ao invadir o espaço secreto, íntimo, dos supostos amantes, constata-se, além da inversão não esperada pelo herói, ou seja, o surpreendente desafio para defender a própria honra e a da mulher, uma quebra de fronteiras, dos limites, no que tange as conveniências da liberdade do próprio indivíduo.

A questão da liberdade, que pertence à categoria superior, vertical e aberta, nesta situação é fortemente denotada pela reação da heroína que, ao voltar para casa, tenta assassinar o marido. Essa idéia de liberdade está presente ao longo da narrativa e é carregada pela heroína, que se opõe à mão-de-ferro do marido para dominá-la. Domínio e liberdade são duas forças que se contrapõem e geram o principal conflito da novela. A idéia em sua totalidade é carregada por essa oposição. Os contrastes evidenciados são: Ela, rebelde, agressiva, indisciplinada / corajosa, magnânima, pura, astuta, inteligente; Ele, covarde, mesquinho, medroso / defensor-salvador.

A tentativa de assassinato do marido pode ser justificada pelas razões da heroína, pela falta de verdade, de liberdade e de honra-dignidade. A situação da tentativa de assassinato, que o herói qualifica de "um duelo terrível de vida ou morte, o duelo daquele mesmo covarde de ontem, expulso pelos companheiros por sua covardia ${ }^{220}$, libera o herói de seu trauma e produz o efeito de redenção. O herói, ao ter enfrentado a morte, sente-se vingado de seu passado sombrio, que manchava a sua honra e que o afligia a cada minuto.

\footnotetext{
${ }^{219}$ DOSTOIÉVSKI, F. M. Krótkaia (A Dócil). Obras Completas, Tomo 10. Leningrado: Naúka, 1982, Cap. I, $5^{\mathrm{a}}$ parte, p.398.

${ }^{220}$ Ibidem, Cap. I, $6^{\text {a }}$ parte, p.402.
} 
Terceira parte: a punição, o castigo, o isolamento, a liberação.

A Dócil, por ter tentado assassinar o marido, sofre a punição, o castigo, pelo seu crime, apesar deste ter-se convertido em regenerador da auto-estima do herói. Ele compra um biombo e uma "pequena cama de ferro", que estabelecem o lugar que Ela ocupa na casa, a partir desse momento, e a condição de pobreza a qual Ela está reduzida, demarcando um novo território entre eles. Ele diz: “Ela está vencida, mas não está perdoada” ${ }^{221}$. Há não só separação de corpos, mas de espaço, dentro de um espaço comum, onde é ainda possível manter a vigilância sobre a condenada. A pressão desses fatos leva a heroína a um estado febril, e nas seis semanas seguintes, em que se encontra inconsciente e delira, Ele vela dia e noite por Ela e reza pedindo a Deus que Ela não morra.

Num primeiro plano, o alto e o baixo aparecem sob o enfoque de poder/dependência. Condição que se estabelece pela generosidade do marido em zelar pela cativa e enferma esposa: ele providencia médico, medicamentos, alimentos, passeios ao sol, sob vigilância. Concomitante a essa coordenada horizontal, paradoxalmente, transcorre uma mutação nos sentimentos do herói que transcende o nível material-poder/dependência. O herói, nessa situação, mostra secretamente sua generosidade, expande o seu coração, enfraquece sua mesquinhez, eleva seu espírito e, apesar do temor, tece sonhos, alimenta esperanças, encontra de certa forma a paz. Paz no sofrimento.

[...] Tu não imaginas o que eu suportei gemendo ao seu lado durante a doença. Eu gemia surdamente e sufocava os gemidos no meu peito, [...] Eu não podia conceber, nem sequer supor que tu morresses sem saber de tudo. ${ }^{222}$

A sua alma e a sua mente passam por um processo de amaciamento, de flexibilidade e de expansão e dá evasão aos sentimentos de piedade e compaixão. Simultaneamente a esses sentimentos por vê-la "tão arrasada, tão esmagada" ${ }^{223}$, vive numa espécie de estado de isolamento contemplativo, tece sonhos de uma vida futura feliz e pratica desinteressadamente algumas boas ações. O “carrasco” se humaniza e vemos a espiritualidade dominar, o vertical se impondo ao horizontal. A inconsciência,

${ }^{221}$ DOSTOIÉVSKI, F. M. Krótkaia (A Dócil). Obras Completas, Tomo 10. Leningrado: Naúka, 1982, Cap. I, 6aparte, p.403.

${ }^{222}$ Ibidem, Cap. II, 6 $6^{\mathrm{a}}$ parte, p.404.

${ }^{223}$ Ibidem, Cap. II, $2^{\mathrm{a}}$ parte, p.407. 
o estado febril, a debilidade física e moral, a culpa, a doença, o desvelo, a humanização, o ensimesmar-se, os devaneios, as descobertas, o amor, são estados opostos aos que geraram os conflitos das situações anteriores. Domina, agora, o interno sobre o externo, o cheio sobre o vazio, destaca-se o silêncio da trégua, da alienação da alma. Cada um permanece em seu próprio mundo, fechado e dividido, mas que se encontra em processo de mutação. Quando a Dócil recupera a consciência, o herói continua em seu enigma, e Ela em seu canto silenciosa. "Decidi adiar nosso futuro [...] deixando, enquanto isso, tudo tal como estava". 224

Aqui Dostoiévski parece falar da impossibilidade de saber tudo o que se passa no interior de um homem, das intenções e motivos de seu agir, de seus sentimentos e de que todos os julgamentos que se possa fazer se constituem de meias verdades, "Aquilo que é secreto permanece no peito desse homem" [...] "eu sou um enigma”. 225

Na narrativa, num esforço para decifrar toda a verdade e compreender realmente as causas da tragédia, faz revelações sobre o seu passado, expõe o seu verdadeiro caráter, confessa suas dificuldades afetivas.

Na confissão que faz a esposa, Ele declara que jamais gostaram dele, nem mesmo na escola, não fala dos pais nem da infância, mas confessa sua incapacidade em expressar os sentimentos. "Sofre calado", tem medo de parecer ridículo. Constata-se oposição quanto às emoções entre o herói e a heroína. A Dócil vem de uma família em que havia harmonia, os pais contavam-lhe histórias quando criança, havia amor, enquanto Ele é analfabeto em relação às afetividades.

A canção expressa pela heroína, após a recuperação da doença, quebra o silêncio dominante que se estabeleceu entre eles, demonstra a reestruturação interna, o renascimento para a vida, a autonomia, a libertação que transcorre no interior da personagem. Esse fato é transformado em acontecimento por Ele, pois traz o reconhecimento de sua cegueira durante o inverno, em que esteve alienado, em devaneios e estados de êxtase, dividido entre o amor e o ódio e, ao mesmo tempo, tecendo sonhos de uma vida feliz, e indaga: "tinha estado eu junto de minha alma?”. ${ }^{226}$ A transformação interna das personagens está associada à estação do ano, ao inverno, quando aparentemente tudo dorme, mas a vitalidade da semente continua agindo internamente.

${ }^{224}$ DOSTOIÉVSKI, F. M. Krótkaia (A Dócil). Obras Completas, Tomo 10. Leningrado: Naúka, 1982, 1982, Cap. II, 6aparte, p.404.

${ }^{225}$ Ibidem, Cap. I, $3^{\mathrm{a}}$ parte, pp.390-391.

${ }^{226}$ Ibidem, Cap. II, $2^{\mathrm{a}}$ parte, p.410. 
Pela canção a heroína expressa a impossibilidade de domínio interno e o herói surpreso se pergunta: "ela está cantando, será que esqueceu de mim? [...] Subi a escada correndo... entrei... era como se todo o chão ondeasse e eu flutuasse num rio". ${ }^{227} \mathrm{E}$ semiconsciente, agora, do lugar que ocupa no coração da heroína, precipita-se desesperadamente em busca do tempo perdido, da felicidade, com declarações, confissões, arrependimentos, promessas, aspirações, juras de amor eterno. Essa atitude do herói, no seu desespero para reconquistar o amor da heroína, torna-se patética. Percebe-se o terror dela opondo-se ao êxtase dele, o que cria o trágico.

A precipitação obsessiva do herói e a impotência da frágil heroína em corresponder a suas aspirações, levam-na ao suicídio, o que gera uma oposição ao ideal perseguido por Ele. O choque entre o real e o ideal se dá na heroína, pois sob a influência da literatura romântica, que mostra o amor ideal, o amor sublime, é levada a preferir a morte a viver sem esse ideal. Ela espera a realização espiritual com a união, mas a falta de correspondência a seus sentimentos gera sofrimento e angústia, causa uma ruptura entre o amor ideal e o estado da alma. A imagem sagrada junto ao peito assume o significado de protesto contra a vida de desamor e também denota a pureza e a inocência da heroína, que não foi reconhecida nem entendida em sua identidade.

Com a trágica morte da heroína, Ele destitui todo o mundo ordenado, esbraveja contra todo o constituído e lança seu protesto desesperado e solitário. A idéia que se estabelece através dos choques dos protagonistas se impõe de forma clara e transcende ao espaço da ação, ao microcosmo do conflito entre as personagens. As relações se multiplicam para além das fronteiras locais e nacionais, para outros níveis espaciais, e se alcança assim a universalidade da idéia.

\section{O Espaço Artístico}

De acordo com Reis ${ }^{228}$ (1950- ), o espaço é uma categoria fundamental da narrativa, pelas articulações funcionais com as demais categorias e pelo significado que o caracteriza. O espaço é um conjunto de relações existentes entre os lugares, o meio, o cenário da ação, as pessoas envolvidas na ação, os eventos e as personagens que neles participam. Ele integra os componentes físicos que servem de cenário, onde se desenvolve a ação, o movimento das personagens, cenários geográficos, ruas, objetos, o

\footnotetext{
${ }^{227}$ DOSTOIÉVSKI, F. M. Krótkaia (A Dócil). Obras Completas, Tomo 10. Leningrado: Naúka, 1982, Cap. II, $2^{\mathrm{a}}$ parte, pp.409-410.

${ }^{228}$ Carlos Reis, Professor Catedrático da Universidade de Coimbra, Portugal.
} 
espaço social, o espaço psicológico. ${ }^{229}$ Segundo Bakhtin, “Dostoiévski via e pensava seu mundo predominantemente no espaço e não no tempo. Daí sua profunda atração pela forma dramática". ${ }^{230} \mathrm{O}$ autor percebia tudo em coexistência, em contigüidade e em simultaneidade situada no espaço, o que lhe permitia dramatizar

as contradições e etapas interiores do desenvolvimento de um indivíduo, obrigando os personagens a dialogar com seus duplos, com o diabo, com o seu alter-ego e com sua caricatura. ${ }^{231}$

Na novela A Dócil, através do recurso do monólogo interior, evidencia-se o espaço psicológico das reflexões e autoconsciência do herói. É um espaço concentrado onde Ele realiza suas confissões, "cenário como luta íntima e como voz cindida da personagem”. ${ }^{232}$ Como já foi mencionado, a narrativa transcorre em um único espaço, a sala onde jaz a mulher morta, a casa de penhores, descrita pelo próprio herói, contendo duas salas - uma sala grande, onde está o caixa de penhores, e a outra um aposento privado (sala e quarto). A ação da história, dos acontecimentos, narrada pelo herói, transcorre em vários ambientes internos e externos. A personagem informa sobre as suas saídas à rua, ao mercado, à praça, ao teatro. Outro lugar que possui uma conotação simbólica é o da cena do pedido de casamento, que ocorre no portão da casa da Dócil, citado muitas vezes pelo herói. Outro espaço referido é no momento do enfrentamento com o oficial inimigo, em que inicialmente esconde-se atrás da porta do quarto ao lado, para ouvir, e depois invade o quarto contíguo para salvar a mulher. O segundo capítulo da novela, no que corresponde ao passado, transcorre praticamente no ambiente íntimo da casa, sala-quarto do casal, separado este por um biombo, o que limita o espaço, dando conotação de opressão. E o pátio, onde a vítima se joga da janela.

A novela A Dócil se passa na cidade de São Petersburgo. Percebemos o espaço da cidade como aberto, horizontal, onde todos circulam em busca de seus interesses. Dentro desse espaço, há os excluídos, e são esses que Dostoiévski enfoca na novela. Esse espaço é explorado e dado a conhecer essencialmente pelo herói e pela heroína, tendo como pano de fundo uma luta pela inclusão social e, com ela, a regeneração moral. O jornal é o maior símbolo de espaço de oportunidades, mas nem sempre

\footnotetext{
${ }^{229}$ REIS, C.; LOPES, A. C. M. Dicionário de Teoria da Narrativa. São Paulo: Ática, 1988, pp.204-208.

230 BAKHTIN, M. Problemas da Poética de Dostoiévski. $3^{\mathrm{a}}$.ed, Rio de Janeiro: Forense Universitária, 2002, p.28.

${ }^{231}$ Ibidem, pp.28-29.

${ }^{232}$ REIS, C.; LOPES, A. C. M. Dicionário de Teoria da Narrativa. São Paulo: Ática, 1988, p.206.
} 
corresponde às expectativas que as pessoas depositam nele, a exemplo da heroína, que gasta todas as economias com os anúncios e não consegue emprego. Assim, o jornal tem conotação negativa, pois ele é ilusório e sensacionalista.

Para o herói, a cidade é um espaço, sobretudo para negociar, especular, buscar informações e espionar. Para Ela, a cidade é um espaço de luta, na busca de emancipação e trabalho, enfim, de liberdade. A Dócil, apesar de ter estudado para ser preceptora, se preparado para conquistar a sua independência, não consegue emprego e tem como única opção cair nas mãos do penhorista. Este tem planos futuros de inclusão na sociedade da qual foi excluído, pois a atividade exercida por Ele, no presente, é apenas um meio para atingir mais rapidamente o seu objetivo.

Sonha em ser feliz, "com a mulher amada, com uma família”, "junto a montanhas e vinhedos”233, e ser incluído numa comunidade humana fraternal. Esse sonho de felicidade é num lugar distante, na Criméia ou em Bologna, pois parece impossível, para o herói, que seja realizado em São Petersburgo por ser um lugar de negócios, especulações, trabalho, sofrimento e condições climáticas não favoráveis. Quando Ele sai para a rua, transtornado por ter ouvido a canção da mulher, descreve as ruas da cidade como um lugar aglomerado de gente, tumultuado. As pessoas circulam nas ruas abarrotadas, se dão encontrões, apesar da amplitude das ruas não há ordenação. Ele vai até a esquina pede ao cocheiro para ir até determinada ponte da cidade. Lá se dá conta que não sabe porque está ali.

Essa imagem caótica da cidade, multiplica o seu caos interno: o externo reforça o interno. Quando o herói fala de seu passado mais remoto, relata as condições desumanas de existência de então: “Eu cheguei a passar as noites na Siénnaia, na casa Viáziemskii junto com toda a espécie de gente”. 234

A cidade é aberta, porém tem conotação negativa. Nela há camadas sociais bem definidas, fechadas, fronteiras que se multiplicam a cada passo. Testemunham isso, além dos clientes desesperados que chegam ao estabelecimento para empenharem seus pertences, as condições em que vivem as tias, em um lugar qualificado por Ele de lama, degradado, no qual a heroína vive em condição social desumana, de submundo, como escrava que está à venda. Entre Ele e Ela também se estabelecem fronteiras sociais, apesar de ambos estarem à margem.

\footnotetext{
${ }^{233}$ DOSTOIÉVSKI, F. M. Krótkaia (A Dócil). Obras Completas, Tomo 10. Leningrado: Naúka, 1982, Cap. I, $4^{\mathrm{a}}$ parte, p.394.

${ }^{234}$ Ibidem, Cap. I, $5^{a}$ parte, p.397.
} 
O espaço da casa do penhorista, onde jaz, em cima de duas mesas de jogo encostadas, sua mulher, que se suicidou, é o mesmo espaço em que as contradições entre o casal se aguçaram, o que resultou nesse fim trágico. Esse espaço descrito pelo herói contém dois níveis: o inferior, onde fica uma grande sala dividida com a caixa de penhores, e o superior, ligado por uma escada, onde fica o quarto de dormir. Percebemos uma conotação simbólica entre os níveis superior e inferior e entre a divisão do espaço da caixa penhores e os cômodos da casa. Esses significados estão intimamente ligados à relação entre o casal e a atividade profissional do herói. Na parte inferior, coexistem dois espaços num mesmo espaço, a caixa de penhores e o lar, que criam um antagonismo pelo significado que encerram.

A casa de penhores é o espaço onde se desenvolve grande parte do enredo, a história, que inicia a partir do momento em que o herói conhece a heroína e se estende até a sua morte. É um espaço fechado, a porta é trancada e aberta após o toque da campainha, por Ele ou a criada. Diz Ele: “eu não possuo homens fortes, nem cães para proteção, como o fazem os outros penhoristas, por isso possuo uma arma”. ${ }^{235}$

A casa de penhores não é um ponto comercial aberto, onde todos podem entrar e circular. Esse controle é uma barreira que vem de dentro e de fora. A atividade é perigosa, exige cuidado, parece não permitida oficialmente, mas “tolerada”, recebendo o espaço, dessa forma, conotação negativa, por se encontrar à margem da sociedade, sendo, portanto, imoral, segundo os padrões gerais aceitos e constituídos de então. Há fronteiras estabelecidas entre o legal e o ilegal, e nosso herói se sente constrangido em tal situação. Acha-se exposto ao julgamento dos olhares alheios, como também sofre por se ver excluído, e este é mais um ponto traumático do herói, pois sofre da síndrome de exclusão social. Sua profissão, caracteriza-se por manipular e explorar os que se encontram em dificuldades, pessoas que se desfazem de seus pertences por necessidade. A atividade se alimenta da desgraça alheia, tendo como único objetivo buscar o lucro garantido, "porque nós só aceitamos ouro". ${ }^{236}$ Quanto pior para os outros, melhor para o negócio. Quando as pessoas entram na casa para empenhar seus objetos buscam a salvação de problemas financeiros, mas também trazem a destruição da casa, da vida privada do casal, o que parece uma espécie de vingança.

\footnotetext{
${ }^{235}$ DOSTOIÉVSKI, F. M. Krótkaia (A Dócil). Obras Completas, Tomo 10. Leningrado: Naúka, 1982, Cap. I, $5^{\mathrm{a}}$ parte, p.400.

${ }^{236}$ Ibidem, Cap. I, $1^{\text {a }}$ parte, p.381.
} 
As divergências geradas pelos diferentes pontos de vista do casal sobre o tratamento com os clientes, a avaliação dos objetos, somadas às intrigas sobre o passado do herói, que alguns semeiam ao freqüentarem o estabelecimento, reforçam a discórdia entre o casal. Esse conflito é gerado porque Ela quer reverter o significado negativo do espaço da caixa de penhores, tornando-o um espaço sagrado, verdadeiro, onde possa realizar o Bem. Essa atitude caracteriza a índole de valores da heroína, que tem raiz cultural e humana.

A reversão no espaço, de ponto comercial para o da prática do Bem, também acontece pela atitude do herói, quando realiza algumas ações desinteressadas. Nesse mesmo espaço, que gerou tantas brigas, acontece também o processo de desvelamento de sua autoconsciência, quando Ele, diante do caixão com a mulher morta, investiga as causas da tragédia e descobre algumas verdades, transcendendo, dessa forma, para um nível mais profundo e humano, o significado da sua atitude para com a heroína.

Tanto no espaço interno da casa quanto no da cidade, há luta constante, gerada pela competitividade, para os indivíduos se estabelecerem social e humanamente diante da penosa existência. O oratório com a lamparina acesa e os ícones denotam o paroxismo da atividade depredadora com a necessidade de proteção, o demoníaco e o sagrado convivendo no mesmo espaço. A casa de penhores agrega o lugar da família e os negócios. Aqui, Dostoiévski inverte o espaço primordial da família, equivalente ao paraíso, e a casa torna-se o inferno. Sobre essa inversão Lotman ${ }^{237}$ (1922-1993) diz que Dostoiévski "muda o modo característico da casa: fria, sempre alheia, estranha e hostil a qualquer intimidade, isso-pseudônimo de, 'casa morta' através da qual transparece o contorno do inferno de Dante”. ${ }^{238}$

É um espaço de depredação e opressão. Nela há medo, discórdia, silêncio e degradação humana. O herói aplica o mesmo procedimento da vida profissional às relações afetivas. Ele, em seu lugar de trabalho e de negócios, isolado em si mesmo, tece planos, projetos, sem sentimentos e paixões, à base do cálculo. Nesse espaço não existe comunicação, há silêncio. Não há relacionamento nem comunhão. Não há lugar para a fraternidade, compaixão, ou amor.

\footnotetext{
${ }^{237}$ Juri M. Lotman, filólogo russo, teórico e cientista da semiótica, literatura e cultura. Membro fundador da Escola Semiótica de Tartu - Moscou.

${ }^{238}$ LOTMAN, Iu. M. Óbrazy priródnykh stikhíy v rússkoi literatúre [Púchkin-Dostoiévski-Blok] (As imagens dos elementos da natureza na literatura russa [Puchkin-Dostoiévski-Blok]). In. LOTMAN, Iu. M. Puchkin - biográfia pissátelia (Puchkin - biografia do escritor). São Petersburgo: Iskusstvo, 1995, p.817.
} 
A Dócil, após a doença, encontra-se silenciosa e isolada em sua mesa de trabalho, numa imagem de submissão e aceitação de sua condição de prisioneira do marido. De súbito, esse quadro, aparentemente estático e definitivo, é quebrado, e criase uma oposição entre o espaço fechado e opressivo da casa e o espaço interno da heroína. Essa ruptura é determinada pela canção da heroína, que possui conotação positiva, de liberdade interna, portanto de espaço aberto. No espaço fechado da casa também se constata a oposição às aspirações de autonomia, a independência e amor da heroína. O amor é um espaço aberto, pois nele dominam a compreensão, a cumplicidade, a tolerância, a generosidade e a compaixão.

A morte assume um aspecto positivo, pois tem relação com o espaço aberto, que é reforçado pela escolha da heroína, que voa pela janela apertando a imagem sagrada junto ao coração, rompendo, desta forma, com a opressão do espaço interior, fechado da casa, em busca de liberdade. Com esse salto para o externo, Ela resgata a imagem sagrada e a si mesma; elege uma vida liberta, transcendente, atemporal. Concomitantemente à idéia de liberdade, na atitude da heroína, constata-se um paroxismo entre o suicídio, a negação da vida, e a imagem sagrada. Seria o suicídio da heroína uma forma de rebeldia contra o mundo existente? Diante da impotência frente à ordem estabelecida, há uma única esperança, o amor do Sagrado? Palavras do herói: “Ah ignorância! Ah natureza! Os homens estão sozinhos na terra - essa é a desgraça! [...] Homens amai-vos uns aos outros”. 239

Os objetos também pertencem à categoria de espaço, e quanto a isso Grossman qualifica Dostoiévski como o mestre da caracterização psicológica, em que dramatiza os objetos habituais do cotidiano, dizendo que:

Penetra na ação a imagem-objeto, que pareceria estranha a luta interior e ao conflito de idéias. E, no entanto, ela adquire importância fundamental no drama e, não raro, torna-se parte essencial, voltando no curso da ação e comunicando um ritmo interior aos acontecimentos do entrecho em progresso. A repetição dos motivos típicos ocorre, em Dostoiévski, também no mundo inanimado, que reflete, em seus pormenores sugestivos, a dor e as aflições das criaturas vivas. ${ }^{240}$

\footnotetext{
${ }^{239}$ DOSTOIÉVSKI, F. M. Krótkaia (A Dócil). Obras Completas, Tomo 10. Leningrado: Naúka, 1982, Cap. II, 4 a parte, p.419.

${ }^{240}$ GROSSMAN, L. Dostoiévski Artista. Rio de Janeiro: Civilização Brasileira, 1967, p.155.
} 
Enfatiza que "Dostoiévski não procura dar vida aos objetos inanimados, mas comunica-lhes uma vitalidade peculiar, capaz de inspirar emoções de horror". ${ }^{241}$ Acrescenta que "são inesquecíveis em A Dócil, as botinhas da suicida", que "estão junto à cama como que a esperá-la”. ${ }^{242} \mathrm{O}$ herói transforma-as em símbolo de beleza e fascínio.

Outros objetos na novela que possuem forte conotação simbólica e que determinam a essência e o estado psicológico das personagens nas situações limites são a Imagem de Nossa Senhora, a lamparina, a escada, o revólver, a cama, o biombo, o relógio. Dostoiévski além de dar caracterização psicológica e dramatizar os objetos, torna-os parte da ação, da luta interna das personagens, comunicando-lhes emoções positivas e negativas. No desespero final da narrativa, o herói assim refere-se ao relógio: “o pêndulo bate insensível, nauseante. São duas horas da madrugada. ... Não, é sério, quando a levarem amanhã, o que vai ser de mim?”. ${ }^{243}$

A imagem da Virgem com o Menino tem forte conotação simbólica, associada essencialmente à heroína, e está presente ao longo da trajetória do enredo. Assim como os ícones, a lamparina, a mortuária branca, simbolizando a pureza da heroína, são objetos que possuem uma relação com o eterno, o espiritual; o revólver é tratado como símbolo ambíguo, de proteção e violência; a pequena cama de ferro e o biombo, como símbolos de pobreza; já o relógio e o caixão são objetos frios, e estão fortemente ligados à catástrofe. $^{244}$ Os objetos determinam a essência e o estado psicológico das personagens, impregnando as tensas situações de atmosferas peculiares, como também designam valores sociais, culturais, espirituais e humanos.

\section{O Tempo Artístico}

A história é narrada pelo herói numa seqüência temporal que coincide com o tempo objetivo do mundo real, o tempo da enunciação. Esse tempo é o da narrativa, o qual corresponde ao fluxo dos pensamentos, ao estado psíquico do herói no ato presente em que expressa o monólogo, a revelação da autoconsciência. O recurso do monólogo interior, utilizado pelo autor, possibilita, pelo seu princípio eclíptico, que a ação da

\footnotetext{
${ }^{241}$ GROSSMAN, L. Dostoiévski Artista. Rio de Janeiro: Civilização Brasileira, 1967, p.156.

${ }^{242}$ Ibidem, p.156.

${ }^{243}$ DOSTOIÉVSKI, F. M. Krótkaia (A Dócil). Obras Completas, Tomo 10. Leningrado: Naúka, 1982, Cap. II, $4^{\mathrm{a}}$ parte, p.419.

${ }^{244}$ LOTMAN, Iu. M. Óbrazy priródnykh stikhíy v rússkoi literatúre [Púchkin-Dostoiévski-Blok] (As imagens dos elementos da natureza na literatura russa [Puchkin-Dostoiévski-Blok]). In. LOTMAN, Iu. M. Puchkin - biográfia pissátelia (Puchkin - biografia do escritor). São Petersburgo: Iskusstvo, 1995, pp.815-820.
} 
narrativa se dê no tempo presente, o tempo da enunciação, tempo do mundo real, durante o qual viabiliza a representação da corrente da consciência. Em A Dócil o autor outorga ao herói investigar o que aconteceu e descobrir a verdade, ou seja, os motivos que levaram a mulher a dar fim a sua vida. O autor esclarece no prefácio que o processo da narração prolonga-se por algumas horas, com interrupções e pausas. O herói informa que “...há 6 horas que já estou tentando aclarar...”. ${ }^{245}$ Trata-se de uma citação direta dos pensamentos da personagem em primeira pessoa e no presente.

Conforme Reis, o tempo subjetivo, psicológico do monólogo interior possibilita a abertura do tempo vivencial da personagem, diferente do tempo cronológico, linear, que comanda o desenvolvimento das ações nas quais as personagens estão envolvidas. A ordem temporal é a relação entre história e discurso, que constitui um domínio de organização da narrativa. Estudar a ordem temporal de uma narrativa é confrontar a ordem de disposição dos eventos ou segmentos temporais no discurso narrativo com a ordem de sucessão desses mesmos eventos temporais na história. A disposição da história é alternada pelo anacronismo no discurso. A reordenação da história ao nível do discurso, a seqüência de eventos, de acordo com a sua ordem de ocorrência (causa e efeito), subsume a dimensão temporal. ${ }^{246}$

Em A Dócil, a relação entre a história e o discurso, ou seja, a ordem temporal, se estabelece praticamente sobre o passado, que constitui a linha fundamental pela qual é conduzida a narrativa pelo herói. A ordem de disposição dos acontecimentos é reordenada pelo herói de forma a obedecer a uma seqüência que vai do esclarecimento inicial: Quem era eu e quem era ela, em que o Oficial/Agiota esclarece como se conheceram, o seu interesse pela heroína e as estratégias utilizadas para chegar à conquista, ao casamento, à relação conjugal até a trágica morte.

Nessas digressões estão intercalados acontecimentos que esclarecem o passado mais longínquo da heroína, investigada pelo herói, e sobre si mesmo. Esse procedimento pode ser evidenciado no fragmento Um sonho de orgulho, em que, diante do sofrimento presente, o herói faz uma confissão e esclarece o seu passado de degradação e humilhação. Essa reordenação discursiva na narrativa se dá, segundo Reis $^{247}$, através de articulações anacrônicas dos acontecimentos e são viabilizadas pelas motivações do herói subjacentes às reordenações: relação dialética passado/presente,

${ }^{245}$ DOSTOIÉVSKI, F. M. Krótkaia (A Dócil). Obras Completas, Tomo 10. Leningrado: Naúka, 1982, Cap. I, $1^{\mathrm{a}}$ parte, p.380.

${ }^{246}$ REIS, C.; LOPES, A. C. M. Dicionário de Teoria da Narrativa. São Paulo: Ática, 1988, pp.266-270.

${ }^{247}$ Ibidem, p.269. 
apresentadas numa óptica casualista-determinista das raízes remotas das motivações de certas situações e ocorrências, recuperação de fatos necessários para se compreender, em termos funcionais, o contexto temático, ideológico que caracteriza a narrativa.

Os acontecimentos em $A$ Dócil não se dão de forma linear, mas são ordenados pelo fluxo da consciência, das reminiscências, ligados ao estado interno, psicológico e subjetivo da personagem. A narrativa se passa em algumas horas, é um tempo real, não cronológico, poder-se-ia classificá-lo como um tempo teatral, ou seja, que se dá no aqui e no agora em que, segundo Peter Szondi, “o presente do drama é absoluto porque não possui nenhum contexto temporal: 'O drama não conhece o conceito de tempo'. 'A unidade de tempo significa o estar-destacado do tempo,", ${ }^{248}$

O caráter do tempo nas situações do texto A Dócil, a condensação temporal, o retardamento, o aumento de velocidade estão ligados à centralidade da ação. A velocidade na sucessão dos acontecimentos narrados, o deslocamento temporal, o tempo cronológico e o psicológico coexistem. Quando a personagem não consegue avançar na narrativa, ela mesma alerta sobre a necessidade de acelerar o andamento do relato. Essas observações do autor feitas pela personagem causam um estranhamento e a situam na perspectiva do receptor. O tempo do receptor se dá através da intervenção do autor, sobre o andamento temporal da história, mediada pela personagem: “vou encurtar esse quadro"249; “"Mais rápido, mais rápido...”. 250

Para Bakhtin, "O dinamismo e a rapidez são a superação do tempo, é o único meio de superar o tempo no tempo". ${ }^{251}$ E afirma que a categoria fundamental da visão artística de Dostoiévski é a de “coexistência e interação". ${ }^{252}$ Pois o tempo e o espaço em Dostoiévski estão relacionados organicamente aos elementos estruturais da obra. A concentração da ação num determinado espaço é atribuída a essa exigência não biográfica da narrativa. Toda a vida da personagem é revista dentro desse espaço de tempo do relato confessional, que está intimamente ligado ao espaço em que a ação transcorre - sala onde a mulher jaz morta.

O tempo artístico da narrativa é engendrado pelo autor, com a eleição dos acontecimentos significativos da vida do herói, que são vistos sob a retrospectiva do

\footnotetext{
${ }^{248}$ SZONDI, P. Teoria do Drama Moderno [1880-1950]. São Paulo: Cosac\&Naify, 2003, pp. 92-93.

${ }^{249}$ DOSTOIÉVSKI, F. M. Krótkaia (A Dócil). Obras Completas, Tomo 10. Leningrado: Naúka, 1982, Cap. I, $5^{\mathrm{a}}$ parte, p.396.

${ }^{250}$ Ibidem, Cap. I, $1^{\text {a }}$ parte, p.385.

${ }^{251}$ BAKHTIN, M. Problemas da Poética de Dostoiévski. $3^{\text {a }}$.ed, Rio de Janeiro: Forense Universitária, 2002, p.29.

${ }^{252}$ Ibidem, p.28.
} 
passado, onde há a reconstrução de um tempo mais abrangente, o da memória. Dentro das categorias do tempo, o classificaríamos como tempo reversível, um tempo dinâmico que vai do presente para o passado; um tempo subjetivo, pois o herói volta ao passado para captar a própria essência de sua história. O tempo cronológico é o tempo objetivo, o tempo histórico, que corresponde ao fluxo do tempo, no qual os acontecimentos ocorrem sucessivamente. Os acontecimentos são organizados de tal forma que nos é informado a todo o momento, através da construção sintática da narrativa, o seu transcorrer: quando, depois, pela manhã, à tarde, à noite, logo depois, antes, novamente, naquele tempo, até aquele exato minuto, na mesma hora, para sempre, pela vida inteira, agora mesmo, cinco minutos antes, agora, ainda, mais dois dias, um momento, um repente, todo esse tempo, não mais de dez minutos, precisamente o tempo, nunca mais, uma hora ou duas horas depois ou antes, outra vez, enquanto, uma única vez, ainda há pouco, duas horas da madrugada, quando amanhã, durante o inverno, a primavera chegou, etc. Do fluir dos acontecimentos, da informação detalhada de quando transcorre as ações e de suas repentinas mudanças apreende-se o tempo-ritmo da narrativa.

Em A Dócil percebe-se a tragédia do tempo histórico, móvel, sobre o homem, quando o herói fala do incessante bater do relógio e da impossibilidade de parar o tempo. É a tragédia da vulnerabilidade do homem diante da implacabilidade de estar vivo. O transcorrer histórico é o das fatalidades, das surpresas, das frustrações, das revelações inusitadas que levam à catástrofe. O presente é o inferno da consciência em que o herói está mergulhado. O passado é o dos acontecimentos que culminaram nesse final trágico, que são trazidos à memória. O passado é o grande vilão, mas é ele que possibilita a reflexão presente. O tempo da história é portador da morte, da desgraça, da desventura, da destruição.

É através do tempo cronológico que o passado é reconstruído, no qual transcorrem os acontecimentos determinantes da vida do herói, inesperados, como acasos do destino, que, para o herói, determinam tragicamente a sua vida. A exemplo do episódio no "büffet do teatro", pelo qual foi acusado de não defender o regimento a que pertencia, o herói afirma que estava por acaso naquele local e naquele instante. Novamente, ao ficar sem emprego, por ter saído do regimento, coincidiu de ter seu patrimônio depredado pelo cunhado, obrigado a viver na rua como um mendigo, quando, de repente, é contemplado com uma herança de sua madrinha. E, sobretudo, as duas horas em que se afastou de casa para os preparativos da viagem e os cinco minutos 
que chegou atrasado, não conseguindo evitar a tragédia, são atribuídos ao acaso. Cheguei só cinco minutos atrasado ${ }^{253}$ é o titulo de seu monólogo final. Na consciência do herói, a sua tragédia é engendrada pelo acaso, pela fatalidade que se dá no tempo e no espaço casuais, onde o herói ou está presente, ou não pode evitar a tragédia por estar ausente. Assim ele se justifica: “os senhores acham ridículo que eu me lamente do acaso e dos cinco minutos? [...] O que dói é que tudo não passou de um acaso, um mero, bárbaro, corriqueiro acaso". ${ }^{254}$ É um tempo trágico, fatal, é o lamento da implacabilidade do tempo.

O herói diante da catástrofe é lançado no caos mítico, no universo da consciência, dos pensamentos confusos, que analogicamente transcorrem no tempo mitológico, que é o tempo que tende ao passado, ao primordial, onde do caos surge a ordem. Trata-se de um tempo cíclico e reiterativo.

Na tentativa de ordenar suas idéias, esclarecer o ocorrido e encontrar uma razão plausível para o acontecido, Ele se vê obrigado a ir ao fundo de si mesmo, de sua autoconsciência, deparando-se e enfrentando-se com todos os seus preconceitos, bloqueios e resistências, na revelação de seu lado monstruoso e trágico.

Ao iniciar o mergulho no espaço da memória, o herói traz à tona o passado revisado e refletido e, através desse processo, consegue ordenar de certa forma o turbilhão que se abateu sobre Ele e tomar consciência de seu isolamento, que se torna mais agudo. Ao realizar essa viagem no passado, Ele toma consciência de sua solidão, de sua exclusão social e humana, de sua própria natureza e de seu caráter demoníaco. Ele está só, com os objetos, os cômodos vazios, e o relógio, indiferente a tudo, continua a bater. No início da narrativa, o herói indaga: “Como é que eu vou ficar sozinho?”255, e no fim de seu monólogo diz "não há ninguém, essa é a desgraça [...] Os cômodos, e eu sozinho com os penhores. Quando amanhã a levarem embora, o que vai ser de mim?”. ${ }^{256}$ O estado desesperador do herói é contraposto ao tempo dinâmico, que continua seu ritmo incessante, alheio à sua desgraça. O relógio é um símbolo dessa alienação do tempo que escoa, e o herói, imerso em si mesmo, em sua dor, encontra-se noutra dimensão, a da autoconsciência.

\footnotetext{
${ }^{253}$ DOSTOIÉVSKI, F. M. Krótkaia (A Dócil). Obras Completas, Tomo 10. Leningrado: Naúka, 1982, Cap. II, $4^{\mathrm{a}}$ parte, p.416.

${ }^{254}$ Ibidem, Cap. II, $4^{\mathrm{a}}$ parte, pp.418-417.

${ }^{255}$ Ibidem, Cap. I, $1^{\text {a }}$ parte, p.380.

${ }^{256}$ Ibidem, Cap. II, $4^{\mathrm{a}}$ parte, pp.418-419.
} 
Identificamos outros modelos de tempo artístico, existentes na composição da novela, além dos já analisados: o tempo imóvel, qualificado como o tempo subjetivo das sensações do herói, um tempo passado, gelado, não existente e atemporal, que está ligado ao tempo mítico, irreversível.

Esse tipo de tempo também coexiste com outros modelos de tempo na composição artística da novela, e está relacionado à alma do herói, a alienação de si, e aparece na segunda parte da novela. Quando Ele, nos momentos de felicidade e em seus estados de êxtase, devaneios e sonhos, perde o sentido do tempo, o tempo móvel é contraposto ao tempo imóvel, à vida plena. Também aparece no momento em que o revolver é apontado para sua cabeça e quando a heroína fica em estado febril e inconsciente. Sobre esse tipo de tempo, Lotman afirma que, na poética de Dostoiévski, a percepção do sono, entendido também como sonho, é um prolongamento dos quatro elementos da natureza, e se apresenta como quinto elemento e que tem fonte tradicional.

A continuidade dos elementos como se encontra fora do tempo normal, como instantâneo : Isso paralisa, estaciona o tempo por um instante. Tal sinal atribui-se ao sono. Por isso a agudez da existência do elemento revela-se como 'vida, prolongando-se pela lei do sono'. ${ }^{257}$

O tempo integral, que representa o passado, o presente e o futuro como um conjunto, e que coincide com o atemporal, e que afirma a coexistência de todos os tempos, parece também estar presente na novela como uma apreensão da história, em que o herói projeta todos os seus sonhos para o futuro. Mas, dentro da tragédia em que o herói se encontra, no presente, tem-se a impressão de não haver perspectiva futura, só há desolação, no entanto o autor não fecha a mensagem da narrativa, mas a deixa em aberto, dando lugar ao mistério.

Lotman fala também da estrutura mitológica na consciência artística de Dostoiévski e do interesse do autor pela existência da gênese arcaica das imagens dos elementos da natureza, terra, água, fogo, ar. Diz que:

A sincronia do sistema dos elementos em Dostoiévski é construído de tal forma que o ar , a água, o fogo se contrapõem a terra, a qual

${ }^{257}$ LOTMAN, Iu. M. Óbrazy priródnykh stikhíy v rússkoi literatúre [Púchkin-Dostoiévski-Blok] (As imagens dos elementos da natureza na literatura russa [Puchkin-Dostoiévski-Blok]). In. LOTMAN, Iu. M. Puchkin - biográfia pissátelia (Puchkin - biografia do escritor). São Petersburgo: Iskusstvo, 1995, p.818. 
ocupa posição central nessa estrutura. A terra possui sinal estável , e não móvel [...] Em oposição à terra os restantes elementos móveis infiltram-se na vida humana, destruindo- $a$, arruinando- $a$, trazem ruína ou sofrimento. ${ }^{258}$

Em A Dócil, o mundo da forças da natureza aparece caracterizado pelo inverno, pela primavera, pelo ar, pela névoa, pelo frio, que possuem significados analógicos aos estados internos, psicológicos das personagens, como também às suas existências. Ele indaga: "Onde esteve a minha alma durante todo o inverno? [...] Estava eu junto da minha alma?”259, o que reflete a alienação do herói, nessa estação do ano. A expressão “O inverno a esgotou” 260 demonstra a implacabilidade da natureza, que exige forças sobre-humanas para que sejam suportadas suas intempéries.

“O ar está fresco não vá se resfriar” ${ }^{261}$ são as últimas palavras da criada Lukéria, antes de a heroína se jogar da janela. Isso sugere que a entrada do ar na casa traz novos pensamentos, novas idéias: o exterior subverte o interior. $\mathrm{O}$ ar, elemento móvel, está ligado à destruição, ao demoníaco e está colocado paralelo à morte. A lama (variação da água), outro elemento impuro-demoníaco que é citado pelo herói para representar as condições da heroína: órfã, pobre e escrava. As personagens nas obras de Dostoiévski vivem em luta constante com as forças da natureza. ${ }^{262}$

\section{As oscilações na mentalidade dos heróis}

Os pensamentos do herói apresentam raciocínios infundados, axiomas e máximas vigentes, preconceitos em relação à mulher, sua condição e natureza. Por outro lado, é misterioso, enigmático e supersticioso e atribui o fatalismo ao acaso, sentindo-se inconformado e impotente por não poder controlar as circunstâncias externas, atribui as desventuras ao acaso. Isso pode ser verificado em passagens significativas da vida do

\footnotetext{
${ }^{258}$ LOTMAN, Iu. M. Óbrazy priródnykh stikhíy v rússkoi literatúre [Púchkin-Dostoiévski-Blok] (As imagens dos elementos da natureza na literatura russa [Puchkin-Dostoiévski-Blok]). In. LOTMAN, Iu. M. Puchkin - biográfia pissátelia (Puchkin - biografia do escritor). São Petersburgo: Iskusstvo, 1995, p.818. ${ }^{259}$ DOSTOIÉVSKI, F. M. Krótkaia (A Dócil). Obras Completas, Tomo 10. Leningrado: Naúka, 1982, Cap. II, $2^{\mathrm{a}}$ parte, p. 410 .

${ }^{260}$ Ibidem, Cap. II, $4^{\mathrm{a}}$ parte, p. 418.

${ }^{261}$ Ibidem, Cap. II, $3^{\mathrm{a}}$ parte, p.416.

${ }^{262}$ LOTMAN, Iu. M. Óbrazy priródnykh stikhíy v rússkoi literatúre [Púchkin-Dostoiévski-Blok] (As imagens dos elementos da natureza na literatura russa [Puchkin-Dostoiévski-Blok]). In. LOTMAN, Iu. M. Puchkin - biográfia pissátelia (Puchkin - biografia do escritor). São Petersburgo: Iskusstvo, 1995, pp.815-820.
} 
herói: quando vivia nas ruas como mendigo foi contemplado com uma herança de sua madrinha, com a qual decidiu-se pela caixa de penhores.

Essa escolha, subterraneamente, na consciência do herói, apresenta-se como arquétipo da consciência mitológica: uma má aplicação do objeto mágico, ou seja, a utilização do objeto mágico para o mal leva à destruição. O herói, apesar de ter violado essa "verdade”, por dominar nele uma racionalidade utilitária, ao tentar reconquistar a felicidade renuncia a tudo o que ganhou com a caixa de penhores e diz que doará aos pobres, ficando somente com os três mil iniciais herdados da madrinha. Assim resgata os princípios, há muito sabidos, necessários para poder ser feliz.

Pode-se também depreender disso, outra crença: o poder material associado ao egoísmo, à mesquinhez e ao seu afã em conquistá-lo, independente dos meios utilizados, é destrutivo: leva à morte, à desgraça, ao castigo. Os ícones junto à lamparina acesa, dividindo o mesmo espaço com a caixa de penhores, também remetem a essa ambigüidade do pensamento do herói. Ele e Ela apresentam duas mentalidades com coordenadas que entram em choque - Reto/Curvo: Ele, racional, pragmático, utilitarista, egoísta, individualista e voluntarista; Ela, intuitiva, pura, sentimental, generosa, correta, orgulhosa, rebelde, impulsiva e irracional.

Paradoxalmente, constatamos o afã da heroína em conquistar a independência, a autonomia e a liberdade, o que constitui uma luta pela libertação da mulher de sua época. Essa luta tem sua origem no Ocidente, e é propagada na cultura russa, sendo um de seus ideólogos Stuart Mill (1806-1873), citado ironicamente pelo herói.

A concepção sobre o ideal romântico, que tem sua origem nas leituras de romances do gênero, também atestam essas influências do pensamento ocidental na mentalidade da heroína. Ambos os heróis apresentam ambigüidade entre esses “dois pólos”. Não há um exemplar puro dessa cultura, mas apresentam dominância de uma ou de outra na forma de pensar e agir. Constatamos uma oposição entre vontade/destino.

Ao longo da narrativa percebe-se a incoerência no pensamento do herói, que oscila entre essas duas mentalidades: uma voluntarista e outra mística. Identificamos essa polaridade e a qualificamos como modelo limítrofe, que consiste no espaço do extremo, da fronteira, o ponto de contato do seu com o alheio, de uma cultura que está entre o Ocidente e o Oriente, espaço fronteiriço, que se projeta na consciência do herói. O herói está agarrado a dois mundos, o que gera o conflito, pois a indefinição e o seu estado de ânimo produzem uma tensão aguda. 
Essa bipolaridade, por um lado, está presente na mentalidade do herói, em suas fórmulas de conduzir a vida, na mentalidade utilitária, nas reflexões expressas em seu aprofundamento na autoconsciência. Por outro lado, vemos a sua oposição. Os seus desejos mais íntimos de idealização de uma vida feliz correspondem à integração na comunidade humana. Os acasos, os imprevistos não calculados a que o ser humano está submetido pelo próprio transcorrer da vida, a implacabilidade do destino, que destruiu todas as suas aspirações são fatores que se chocam na mente do herói, que fogem às explicações racionais.

O herói e a heroína parecem constituir uma metáfora do conflito existente entre estes pólos, Oriente e Ocidente. A Rússia é considerada uma ponte entre essas duas culturas, em que dominam fortes oposições entre voluntarismo e fatalismo. As oposições são infinitas, os conflitos insolúveis. Há luta constante para imposição de pontos de vista no nível cósmico: razão/sentimento-coração. 


\section{CAPÍTULO IV}

\section{ADAPTAÇÃO E ANÁLISE ATIVA DE A DÓCIL, DE FIÓDOR M. DOSTOIÉVSKI}

Essa alma doce e humilde que destruiu a si mesma forçosamente tortura o pensamento.

\section{ADAPTAÇÃO DA NOVELA “KROTKAIA” (A DÓCIL) ${ }^{262}$}

Personagens: Ele, Ela, Lukéria e Iefímovitch.

\section{Cena I}

RITUAL FÚNEBRE - Pausa cênica do diretor

Local - Caixa de penhores

Narrativa - Eu não paro de querer esclarecer tudo para mim mesmo. Pois já faz seis horas que eu quero ver claro e não encontro meio de juntar as idéias num ponto. Eis como isso aconteceu: Vou simplesmente contar pela ordem (ordem!). Senhores, vou contar assim como eu mesmo entendo. É aí que está todo o meu horror, eu entendo tudo!

Querem saber, se é para comȩ̧ar do começo, Ela veio a minha casa...

\section{Cena II}

\section{PENHORA DE OBJETOS}

\section{Local - Caixa de penhores}

Ela entra no estabelecimento do Oficial/Agiota para penhorar alguns objetos. Parece agitada.

Ele - Senhorita, nós não trabalhamos com esse tipo de objeto. Ele vale muito pouco.

Ela entrega mais alguns objetos.

Ele - Senhorita, nós trabalhamos somente com ouro puro, estes objetos são mal banhados a ouro. Valem quanto muito 30 copeques.

Ela tira do pescoço a corrente com medalhinha e a entrega para Ele.

${ }^{262}$ DOSTOIÉVSKI, F. M. Krótkaia (A Dócil). Obras Completas, Tomo 10. Leningrado: Naúka, 1982. 
Ele - Tome 50 copeques.

\section{Ela pega o dinheiro e sai rapidamente.}

Ele - (para si) Calada! Os outros discutem, insistem, regateiam para que lhes dêem mais. Essa não, aceita o que derem.

\section{Cena III}

\section{HUMILHAÇÃO}

\section{Local - Caixa de penhores.}

Ela chega com uma jaquetinha velha de pele de lebre. Está perturbada.

Ele - A senhora pretende empenhar isso? Esses "restos" devem ter passado pela guerra contra Napoleão. (ri zombeteiramente)

Ela arranca a jaquetinha das mãos dele e sai indignada.

Ele - Deus meu, como ela enrubesceu! Os seus olhos azuis, grandes e pensativos pegaram fogo. Como é jovem, deve ter no máximo catorze anos!

Narrativa - Esse foi o meu primeiro pensamento sobre Ela. Meus senhores, nunca me permito uma coisa dessas, sou um gentleman com a clientela, poucas palavras, gentil e austero. Acho que estou me atrapalhando todo.

\section{Cena IV}

\section{REVIDE}

\section{Local - Caixa de penhores}

Ela entra na caixa de penhores, constrangida pela situação do dia anterior. Entrega um camafeu.

Ele - (Recebe-a com severidade) Veja, os outros penhoristas não aceitam um objeto assim, eles só querem ouro. Eu só faço isso para a senhora, para a senhora. Moser e Dobroravóv recusariam esse tipo de objeto. Eles não querem nem conversa, a senhora sabe, pois esteve lá, não? (Entrega-Ihe dois rublos. Ela, calada, pega o dinheiro e sai) Ele - (para si) O que é a pobreza! E como enrubesceu! Fui cruel! Dei-lhe uma alfinetada! Será que essa vitória sobre ela vale dois rublos? Eh,eh,eh!! Será que vale? Será que vale? Mas eu que não aceito nada além de ouro e prata, como é que fui aceitar esse camafeu sem valor? 
Narrativa - Esse foi o meu segundo pensamento particular sobre Ela. O que é que está acontecendo comigo? Se eu continuar assim, quando é que vou conseguir juntar tudo num ponto? Ah, Meu Deus!

\section{Cena V}

\section{SUBORNO}

\section{Local - Rua}

Ele - Com licença! A senhora mora aqui?

Lukéria - Sim, senhor! O que deseja?

Ele - É aqui que mora essa senhorita que acabou de entrar?

Lukéria - É... Ela mora aqui, sim senhor... mas por que o senhor está querendo saber?

Ele - É que Ela esteve no meu estabelecimento algumas vezes...

Lukéria - Estabelecimento?

Ele - Eu tenho uma casa de penhores...

Lukéria - Ah! O senhor é o penhorista!

Ele - Bom, uma menina tão jovem indo numa casa de penhores... e com uns objetos que não se costuma penhorar... Por que Ela está penhorando esses objetos?

Lukéria - Porque precisa. Com licença...

Ele - Precisa? O que a senhora é dela? (mostra dinheiro)

Lukéria - Sou Lukéria, a criada. É que a menina precisa pagar os anúncios no jornal, no “Gólos”. Ela quer trabalhar como preceptora, só que ninguém a chamou ainda, e então Ela está penhorando todos os objetos que ficaram do seu papácha e da sua mamácha.

Ele - Objetos que ficaram?

Lukéria - Sim, os pais morreram há três anos. O pai dela foi funcionário público, tinha até um título de nobreza pessoal.

Ele - Então Ela mora sozinha com a senhora?

Lukéria - Não, agora Ela mora com as tias. A pobrezinha tem que trabalhar o dia inteiro em regime de servidão. Ela dá aulas aos seis filhos de uma das tias, que é viúva, 
a outra é uma solteirona. E ainda tem que lavar e, costurar a roupa e com aqueles seus pulmões fracos, até esfregar o chão. E mesmo assim Ela conseguiu, com muito esforço, debaixo de um trabalho desumano, achar tempo para estudar. Foi aprovada e agora pode trabalhar como preceptora.

Ele - (para si) Isso da parte dela significa que aspira ao que é supremo e nobre.

Lukéria - As tias, sem mais nem menos, até batem nela, lhe jogam na cara o pão de cada dia...

Ele - Que velhas detestáveis e desregradas!

Lukéria - E agora, então, aconteceu o pior.

Ele - Mas o que foi que aconteceu?

Lukéria - Não sei se devo contar esse horror que estão querendo fazer com a menina.

Ele - Fale, por favor!

Lukéria - Acabaram fazendo planos para vendê-la!

Ele - Vendê-la?

Lukéria - Sim, para um vendeiro gordo que a vem vigiando há um ano. Ele tem duas mercearias, é daqui da vizinhança. Ele já enterrou duas mulheres e procura uma terceira, de modo que não tira o olho da menina: "Boazinha - diz o vendeiro - calada, cresceu na pobreza, enquanto que eu me caso por causa dos órfãos.” Ele já fez o pedido e começou a se entender com as tias, além do mais - tem cinqüenta anos; Ela ainda não fez dezesseis, está apavorada. Foi por isso que Ela começou a colocar os anúncios com mais freqüência. Pediu às tias que lhe dessem pelo menos uma gotinha de tempo para pensar. As tias deram essa gotinha, mas só uma, não deram outra, começaram a martirizá-la: “Mesmo sem uma boca a mais nós não sabemos o que é comer”. Com licença, Boa Noite.

\section{Ele entrega o dinheiro.}

Narrativa - Investiguei todas as circunstâncias da vida dela. Ela publicava os anúncios com seus últimos recursos, de início com soberba: "preceptora, à disposição inclusive para viajar. Enviar condições pelo correio.” Depois dizia: “à disposição para tudo, dar aulas, dama de companhia, fazer trabalhos domésticos, cuidar de doentes, e sei costurar" etc., etc., tudo isso já conhecido! E no final Ela já estava à beira do desespero e se oferecia até mesmo "sem ordenado, pelo pão." Eu esperava a sua chegada com impaciência. Eu já pressentia quando Ela estava por vir. 


\section{Cena VI}

\section{PROVA}

\section{Local - Caixa de penhores}

\section{Ela chega com uma piteira para empenhar.}

Ele - (Exagera na amabilidade) Bom dia, como a senhorita tem passado? Uma piteira em âmbar? Nada mal! A quem pertence?

Ela -Pertenceu a meu pai, senhor.

Ele - Pertenceu? Quer dizer que a senhorita é órfã? (ela faz que sim) Faz muito tempo?

Ela - Meus pais morreram há três anos, senhor.

Ele - Sinto muito! (para si) Uma pecinha à toa, coisa de amador. - Dois rublos está bem?

Ele - (para si) Vou colocá-la à prova mais uma vez! - A senhorita veja esse anúncio. “Pessoa jovem, órfã de pai e mãe, procura emprego de preceptora de crianças pequenas, de preferência em casa de viúvo de mais idade. Pode ajudar no trabalho de casa” - Veja: essa colocou o anúncio hoje pela manhã, e à tarde, com certeza, já estará empregada. É assim que se deve anunciar!

Ele - Tome os dois rublos.

\section{Ela pega o dinheiro e vai embora.}

Ele (para si) - Corou de novo e os olhos novamente faiscaram. Como é dócil! Bem, piteiras ela não tem mais, já não tem mais nada! Isso me agrada muito!

Narrativa - Foi aí que descobri que Ela era boa e dócil. Agora quero apenas recordar como então, de repente, me veio essa intenção, banquei o importante diante dela e cresci a seus olhos. Escutem! Escutem! Agora sim é que tudo começa, é que até aqui eu só me atrapalhava...

\section{Cena VII}

\section{PENHORA ESPIRITUAL}

\section{Local - Caixa de penhores}

Ela aparece muito agitada. Ele a recebe com cortesia exagerada. 
Ele - E então senhorita? O que temos hoje para empenhar?

\section{Ela mostra a imagem.}

Ele - Ah, uma imagem, o ícone da Virgem com o Menino! Vejo que é antiga, familiar. Uma bela moldura de prata banhada em ouro. Seria melhor que a senhorita tirasse a moldura e levasse o ícone, afinal de contas, não fica bem penhorar uma imagem sagrada.

Ela - E por acaso é proibido para o senhor?

Ele - Não, não é que seja proibido, é que, talvez, para a senhora mesma..., vejo que ele lhe é caro.

Ela - Então tire.

Ele - Sabe de uma coisa? Eu não vou tirar a moldura, vou colocá-lo no meu oratório, junto com as outras imagens, à luz da lamparina. Desde que eu abri o caixa, mantenho uma lamparina acesa. Tome aqui dez rublos..., não faça cerimônia.

Ela - Não preciso de dez, dê-me cinco, venho resgatá-la assim que puder.

Ele - Mas não quer os dez? A imagem vale! Não se deve desdenhar ninguém, senhorita. Eu mesmo estive em tais dificuldades, ou até piores, e se agora a senhorita me vê aqui, nessa ocupação... isso foi depois de tudo o que eu sofri.

Ela - O senhor está se vingando da sociedade? Está?

Ele - (para si) Ahá! Então é assim que você é, seu caráter se revela sob nova direção. Veja senhorita: “Eu! - Eu sou uma parte daquela parte do todo que quer fazer o mal, mas cria o bem”.

Ela - Espere um pouco...Que pensamento é esse? De onde é que vem? Eu já ouvi essa idéia em algum lugar...

Ele - Não precisa quebrar a cabeça, com essa expressão Mefistófeles recomenda-se a Fausto. Já leu Fausto?

Ela - Não... não com muita atenção.

Ele - Quer dizer que não leu absolutamente. Deveria ler. E..., aliás, volto a perceber nos lábios da senhorita um traço de zombaria. Por favor, não atribua a mim tanto mau gosto que, para embelezar o meu papel de penhorista, queira me recomendar à senhorita como Mefistófeles recomenda-se a Fausto. Um agiota vai ser sempre um agiota. Sabemos muito bem disso.

Ela - O senhor é um tanto estranho... Eu não queria, em absoluto, dizer-lhe nada nesse sentido, de jeito nenhum... 
Ele - (para si) Ela queria dizer: "Eu não esperava que o senhor fosse um homem culto”. Incrível, acertei em cheio no que lhe agrada! - (para Ela) Veja: em qualquer profissão pode-se praticar o bem. É evidente que, não estou falando de mim, eu, exceto o mal, convenhamos, não faço nada, mas...

Ela - É claro que se pode fazer o bem em qualquer situação. Sobretudo em qualquer situação.

Ela sai.

Narrativa - Ah, eu me lembro de todos esses momentos. E o mais importante é que eu já a olhava como minha e não duvidava do meu poder. Os senhores sabem como esse pensamento é voluptuoso quando já não se tem qualquer dúvida. Eu, então, estava totalmente decidido!

\section{Cena VII}

O PACTO

\section{Local - Em frente ao portão}

Ele - Lukéria!

Lukéria - Ah! O senhor... Boa -noite!

Ele - Boa noite! A senhorita está? Eu gostaria de falar com Ela.

Lukéria - Ah...a senhorinha... Ela está...mas está acompanhada, o vendeiro está aí! O prazo acabou hoje. Ele trouxe as alianças e o noivado vai ser acertado ainda hoje com as tias. Até uma libra de balas ele trouxe para a menina...

Ele - (nervoso) Mas então Lukéria vá chamá-la.

Lukéria - Mas agora? Ela está lá junto com as tias fazendo sala ao vendeiro, como é que vou poder...

Ele - Vá lá e cochiche no seu ouvido, diga-lhe que tenho algo de caráter muito inadiável para lhe dizer.

\section{Lukéria sai.}

Ele - (para si) Tudo está nas minhas mãos, eu surjo como de um mundo superior. Em todo caso, sou um capitão-mor. Como são horríveis os podres em que Ela está metida! Não consigo entender como ainda era possível rir do jeito que riu há pouco e mostrar curiosidade pelas palavras de Mefistófeles encontrando-se Ela em tal horror. Ah, juventude! Na juventude há grandeza: apesar de se encontrar à beira da ruína as 
grandes palavras de Goethe resplandecem. A juventude ainda que sem rumo é sempre generosa.

\section{Lukéria entra acompanhada pela Dócil.}

Ela - Mas é o penhorista! O que será que ele quer? Ele não disse nada?

Lukéria - Não, só disse que era urgente.

Ela - Boa-noite! Algum problema com os meus objetos?

Ele - Não, senhorita. Não se espante com as minhas maneiras e... com o fato de eu estar aqui no portão...sou um homem direto..., franco e estudei bem as circunstâncias do caso... Para mim é uma felicidade e uma honra poder...

Ela - Uma felicidade e uma honra?

Ele - Sim..., exatamente, considero uma honra e uma felicidade. Em primeiro lugar tenho que lhe dizer que não sou particularmente talentoso, nem demasiado inteligente, talvez nem mesmo bom, mas talvez um egoísta bastante barato e... é bem possível que eu traga em mim muito de desagradável ainda em outros aspectos.

Ela - Por favor, não fale assim de si!

Ele - Mas senhorita..., eu também tenho algumas qualidades: recebi uma boa educação, sou capitão do estado maior, reformado de um brilhante regimento, sou nobre de origem, independente. E se mantenho a caixa de penhores é porque tenho um objetivo: existe uma certa circunstância. Quero que a senhorita saiba que sou eu que fico imensamente grato pelo favor e não a senhorita. A senhorita me concede sua mão em casamento?

\section{Surpresa, Ela se afasta.}

Ele (para si) - Eu já não tenho medo de nada. O merceeiro gordo, de qualquer modo, é para ela mais asqueroso do que eu. Você é alto, bem-apessoado, bem-educado e, em si, não é nada mau.

Ele - E então, como é, senhorita?

Ela - O senhor espere, eu estou pensando.

Ele (para si) - Será possível que ela esteja escolhendo entre mim e o comerciante?

Ele - Estou esperando a sua resposta, senhorita!

Ela - Senhor! Sim... eu aceito.Obrigada. 
Ele - (tira a aliança e a coloca no dedo dela) Eu pensei em celebrar o casamento à la inglesa, isto é, a dois, exceto duas testemunhas, uma das quais pode ser Lukéria. Depois direto para o trem, ir para Moscou, num hotel, ficar lá umas duas semanas, eu tenho mesmo um negócio por lá.

Ela - (devolve a aliança) Não, eu não posso aceitar. Eu quero que seja feito como de costume: que o senhor venha à casa das tias e apresente seus respeitos como parentes de quem o senhor está me tomando e trate com elas os detalhes do casamento. E quanto à viagem, eu prefiro ficar aqui.

Ele - Que seja como a senhorita quiser. Quero acrescentar que a senhorita será bem alimentada. A senhorita e Lukéria, que passará a viver conosco. Mas não vai haver vestidos, bailes, teatros, a não ser, talvez, no futuro, quando eu tiver atingido o meu objetivo, que a senhorita ficará sabendo com o tempo.

Lukéria - Mas e o enxoval? A menina não tem nada! Como é que ela vai se casar?

Ela - Não preciso de nada! Lukéria!

Ele - Sem nada também não é possível! Eu dou muita importância às roupas brancas. Eu dou o enxoval para Ela. Ah, quero acrescentar que a senhorita se ocupará da recepção dos objetos e da saída do dinheiro, e a Lukéria se ocupará da casa.

Ela - Por favor! O senhor me dê licença, eu preciso entrar.

Ele - Por favor! Amanhã eu virei falar com as suas tias e combinarei tudo com elas. Boa noite!

Lukéria - (corre atrás dele) Senhor! Para o senhor poder levar a menina daqui, as tias vão querer algum dinheiro. Elas devem para o vendeiro e o senhor sabe que há tempo elas estão comprando por conta. Agora que o casamento não vai sair, elas vão ter que pagar o homem.

Ele - Não se preocupe, Lukéria, darei a elas o que lhes é devido.

Lukéria - O senhor caiu do céu! O senhor é um salvador! Deus lhe pague por levar a nossa querida menina. Mas não vá dizer isso a Ela, porque é tímida, mas é muito orgulhosa.

Ele - (para si) Ah, Ela é orgulhosa! Que bom que Ela é orgulhosa, eu gosto das orgulhosinhas - Elas são particularmente belas quando... bem, quando já não mais se duvida do próprio poder que se tem sobre elas. 
Narrativa - Ah, que homem baixo, inconveniente! Os senhores sabem, quando Ela estava lá no portão, toda pensativa, para me dizer o sim, Ela poderia ter tido o seguinte pensamento: “ Se a desgraça está aqui e lá, não é melhor escolher logo o pior, isto é, o merceeiro gordo, morto de bêbado, que me mate o mais depressa possível?" Poderia haver um pensamento assim? O que os senhores acham? Entre as duas desgraças, escolher a pior, isto é, o comerciante. Então quem era para Ela o pior? Eu ou o comerciante? O comerciante ou o agiota que cita Goethe. Queria apreender tudo isso, toda essa lama. Ah, que lama! De que lama eu a arranquei então! Ela tinha que entender isso, reconhecer o valor do meu ato!

\section{Cena IX}

\section{O CASAMENTO}

\section{Cena imagética}

Narrativa - Agradava-me saber que eu tinha 41 anos e Ela mal fizera 16. Isso me cativava, essa sensação de desigualdade, era muito doce, muito doce.

\section{Cena X}

\section{RITUAL DE INICIAÇÃO}

\section{Local - Caixa de Penhores}

Ela o surpreende com o revolver.

Ela - Por que o senhor tem essa arma?

Ele - Não mantenho cães enormes, nem criados fortes, como o fazem os outros penhoristas, por isso tenho esse revólver. É para autodefesa.

Ela - Deixa eu ver!

Ele - A senhora gostaria de aprender a atirar?

Ela - Sim, o senhor me ensina!

Ele a ensina a atirar e depois a empossa no caixa.

\section{Cena XI}

ROTINA 


\section{Local - Caixa de Penhores / Rua}

Segue-se uma passagem de tempo que se caracteriza por uma mímesis que dá a conotação da rotina de trabalho do casal e do aumento da tensão cotidiana em sua relação.

\section{Cena XII}

\section{ARREBATAMENTO I}

\section{Local - Caixa de penhores}

Ele chega da rua. Ela recebe-o afetuosamente.

Ela - (Enquanto aquece os pés dele) Sabe, meu pai me contava histórias enquanto eu passava óleo nos seus pés. O senhor conhece alguma história?

Ele - Não.

Ela - Ele sempre contava a história de uma menina pobre - que numa noite de tempestade de neve morreu de fome e de frio.

Narrativa - Quando eu voltava ao anoitecer, Ela me contava, com o seu fascinante balbuciar da inocência, toda sua infância, a sua meninice, sobre a casa paterna, sobre o pai e a mãe. Ela se lançava sobre mim com amor. A minha idéia consistia em responder aos arrebatamentos com o silêncio, dando, logo, um banho de água fria no seu entusiasmo. Ela viu num instante que nós somos diferentes e que eu sou um enigma. E eu apostei nesse enigma! Foi então para que Ela decifrasse esse enigma que eu acabei fazendo toda essa bobagem! Embora me sentindo satisfeito, criei todo um sistema. Ele surgiu por si mesmo, sem esforço. Mas por que é que eu estou me caluniando! O sistema era verdadeiro. Não, escutem, se é para julgar um homem então que o julguem com conhecimento de causa.

Ele - Estão faltando 40 copeques, a senhora colocou em algum outro lugar?

Ela - Lukéria precisou para comprar umas coisas para casa.

Ele - Como assim, precisou? Venha até aqui, por favor.

Ele - Olha, quando nós casamos, eu já havia explicado que seria dado um rublo por dia para a nossa alimentação, e depois eu mesmo aumentei essa quantia em trinta copeques. Eu preciso juntar trinta mil rublos em três anos e não tem outra forma de fazer isso a não ser economizando, a senhora sabe. Até ao teatro, que eu disse que não haveria, nós 
temos ido uma vez por mês. Já fomos três vezes, e com cadeira especial! E tem mais: os objetos estão sendo avaliados acima do valor, sobre isso nós já conversamos...

Ela - O senhor tem que entender que as pessoas precisam!

Ele - Quem precisa?

Ela - As pessoas que vem ao seu estabelecimento.

Ele - Isso aqui não é uma casa de filantropia. Para conseguir meu objetivo é preciso economizar e pagar pelos objetos o que eles valem. A senhora é jovem e não sabe de onde vem o dinheiro, assim é fácil ser generosa. Essa generosidade é admirável, mas não vale um copeque! Pois não resultou do fato de ter vivido, são só as "primeiras impressões da existência”. Mas quero ver como é que se arranja no trabalho árduo.

Ela - Entendo... O senhor tem razão, tem objetivos, isso mostra a sua firmeza de caráter. Pela economia eu renuncio ao teatro.

\section{Ela sai.}

Narrativa - Mas, senhores, a generosidade barata é sempre fácil, e até o sacrifício da própria vida também sai barato, pois é só o sangue que ferve, há um excesso de energia. Tomem uma proeza difícil, abafada, sem esplendor, alvo de difamação, na qual há muito sacrifício e nem uma gota de glória, na qual um homem brilhante é exposto diante de todo o mundo como um infame, quando na verdade é mais integro que todos os homens da face da terra. Bem, experimentem realizar essa façanha. Os senhores se recusariam. Enquanto que eu - eu não fiz outra coisa, em toda a minha vida, senão carregar essa façanha. Foi debaixo de severidade que a trouxe para casa. A juventude despreza o dinheiro, eu me agarrei ao dinheiro, teimei no dinheiro. E insisti tanto que Ela foi emudecendo cada vez mais e mais.

\section{Cena XIII}

\section{ARREBATAMENTO II}

\section{Local - Caixa de penhores}

Ele está obcecadamente fazendo contas, ela tenta aproximação e ele a rejeita.

Ela - O senhor só pensa em trabalho e em dinheiro! Por isso todas as pessoas que vêm aqui dizem que o senhor é um mesquinho, um sovina. Até aquele seu antigo colega de regimento insinuou coisas sobre o senhor.

Ele - Ah, a senhora anda dando ouvidos àquele canalha do Iefímovitch, que veio à loja com a desculpa de penhorar objetos para ficar falando a meu respeito, eu ouvi suas 
risadinhas com ele. Na ocasião eu o proibi expressamente de retornar ao meu estabelecimento em consideração às nossas relações do passado.

Ela - Não foi só ele que falou aquelas vulgaridades. Todos falam sobre o senhor...

Ele - Ah, então a senhora anda colhendo informações sobre a minha vida com essa gente baixa, miserável?

Narrativa - Vejam só: a juventude tem pouca tolerância, basta um porém e vem o desprezo. Mas eu queria infundir-lhe grandeza, direto no coração, infundi-la nos olhos do coração. Como é que eu poderia explicar a minha caixa de penhores a um caráter assim? Fiz uso do orgulho, falava quase calado. É que eu sou mestre em falar calado, passei toda a minha vida falando calado e vivi, comigo mesmo, tragédias inteiras calado. Eu também fui infeliz! Fui abandonado e esquecido por todos, e ninguém, ninguém sabe disso! E, de repente, vem essa menina, recolhe das mãos de gente baixa pormenores sobre mim e pensa que sabe tudo, enquanto o que é secreto permanece apenas no peito deste homem! Queria que Ela descobrisse por si mesma, sem mim, mas não pelas histórias dos canalhas e desse valor. Eu sempre fui orgulhoso, eu sempre quis tudo ou nada! Foi justamente por isso que me vi forçado a agir assim. Porque os senhores hão de concordar que se fosse eu a chegar e lhe explicar, lhe sugerir, bajular e implorar respeito - seria o mesmo que mendigar... Aliás... Aliás, por que é que eu estou falando disso! É estúpido, estúpido, mil vezes estúpido!

\section{Cena XIV}

\section{DEPOSIÇÃO}

\section{Local - Quarto}

Ela - (lendo) "Ela principiou fazendo-me conhecer a ternura dos seus sentimentos pelos movimentos expressivos dos olhos; mas eu, em lugar de lhe corresponder, fingi que não percebi os seus desígnios; o que lhe não desagradou por me supor ainda novato em amor. Julgando inútil a linguagem dos olhos pelo estado de inocência em que me supunha, declarou-se abertamente comigo na primeira conversação que tivemos.”263

\section{Ele entra e fica parado na porta. Ela começa a bater a ponta dos pés no chão.}

Ele - Posso saber o que é isso? A senhora trocou o medalhão que a viúva do general empenhou por esse bracelete? A viúva trouxe o medalhão, que era lembrança do seu

263 LESAGE, A-R. História de Gil Blas de Santillana. Porto Alegre: Mercado Aberto, 1999, p.416. 
finado marido, se desfez em lamúrias e suplicou que o guardasse. Eu dei trinta rublos. Ela voltou pedindo para trocar o medalhão pelo bracelete, que não vale nem oito rublos. É evidente que recusei, a senhora sabe, estava lá e viu tudo. E foi só ela aparecer quando eu não estava que a senhora trocou o medalhão por esse bracelete.

Ela - Mas, senhor a mulher chorou tanto, dava pena de ver.

Ele - Sabe quanto prejuízo eu tive? O dinheiro é meu, eu tenho o direito de ver a vida com os meus olhos, e, quando a convidei para vir para a minha casa, não escondi nada. E foi justamente com esse sorriso zombeteiro que a senhora entrou em minha casa. Como que, depois de ter saído de tanta lama e miséria, depois de ter lavado o chão, de repente inventa de soltar o dinheiro como bem entende e ainda tem a coragem de torcer o nariz para a nossa pobreza! Aliás, não é pobreza, é economia. E há até luxo no que é preciso, na roupa e na limpeza.

Ela começa a tremer e a gritar, tendo um ataque histérico joga-se no chão chorando. Ele se espanta, mas procura manter-se frio.

Ele - A partir de hoje, eu a proíbo de tomar parte nos negócios.

\section{Ela continua chorando e começa a se recompor.}

Narrativa - Ao acolhê-la em minha casa, queria conquistar toda a sua estima. Queria que se pusesse de joelhos diante de mim pelos meus sofrimentos. Eu, então, tinha certeza do seu amor. Uma mulher que ama vai endeusar até mesmo os vícios, os crimes do ser amado. Se o mais generoso dos homens tornou-se um agiota, quer dizer que havia motivos. "Os senhores me repudiaram, isto é, os homens me enxotaram com um silêncio de desprezo. Agora eu estou no direito de me proteger dos senhores com um muro, juntar esses trinta mil rublos e viver o resto dos meus dias em algum lugar na minha propriedade, longe de todos, sem lhes guardar rancor, com um ideal na alma, com a mulher amada no coração, com uma família, se Deus quisesse, e ajudando os vizinhos da comunidade”.

Eis a razão do silêncio orgulhoso, eis a razão de ficarmos calados. O que é que Ela ia entender das minhas justificativas, dos meus sofrimentos, na flor da juventude? Acreditem, eu me tornava intolerável para ela. Ah, como é horrível a verdade sobre a terra! Essa preciosidade, essa dócil, esse céu - Ela era um tirano, o intolerável tirano da minha alma e o meu carrasco. Vocês pensam que eu não a amava? Quem pode dizer que eu não a amava? 


\section{Ela se arruma para sair.}

Ele - Eu vejo cada vez mais um ar de atrevimento da vossa parte.A senhora não pode sair sozinha, isso foi combinado ainda quando éramos noivos. Uma mulher, ainda mais de dezesseis anos, tem que se submeter inteiramente ao marido.

\section{Ela sai às gargalhadas.}

Narrativa - Vejam só: aqui se deu uma cruel ironia do destino e da natureza: nós somos malditos, a vida dos homens é maldita em geral. Agora eu entendo que devo ter cometido algum erro. O meu plano era claro como o céu: “Austero, orgulhoso e não necessita dos consolos morais de ninguém, sofre calado. Eu acreditava que depois Ela veria que aqui houve generosidade - mas só que Ela não foi capaz de perceber! - e, quando adivinhasse isso um dia iria dar dez vezes mais valor e cairia aniquilada, as mãos postas em súplica”. Eis o plano. Mas alguma coisa eu não soube fazer, devo ter perdido alguma coisa de vista. Mas basta, estou farto! E agora pedir perdão a quem? Se está acabado, está acabado. Coragem, homem, e seja orgulhoso! O culpado não és tu!

Bem, então eu vou dizer a verdade, não terei medo de ficar face a face com a verdade: Ela é a culpada, Ela é a culpada!

\section{Cena XV}

\section{INTERROGATÓRIO}

\section{Local - Caixa de penhores}

\section{Ele está lendo o jornal. Ela entra e começa a bater o pezinho.}

Ela - Quer dizer que é verdade que o senhor foi expulso do regimento porque não teve coragem de se bater num duelo?

Ele - É verdade; por uma sentença dos oficiais, fui convidado a me afastar do regimento, apesar de que eu mesmo, antes disso, já tivesse pedido baixa.

Ela - Foi expulso como um covarde?

Ele - Sim, eles julgaram-me covarde. Recusei-me ao duelo não porque fosse covarde, mas porque não quis me submeter a sua sentença tirânica e provocar um duelo, quando eu mesmo não me considerava ofendido. Sabe, ter me revoltado contra tal tirania e ter arcado com todas as conseqüências acabou mostrando muito mais valentia do que quaisquer duelos. 


\section{Ela ri maldosamente e rasga o jornal.}

Ela - E é verdade que depois disso o senhor ficou três anos mendigando copeques como um vagabundo pelas ruas de São Petersburgo e passando a noite debaixo das mesas de bilhar?

Ele - Eu cheguei a passar as noites nos cortiços, no baixo meretrício da cidade, amontoado com toda espécie de gente. Sim, é verdade, depois do regimento houve na minha vida muita vergonha e muita degradação, mas não degradação moral, porque eu mesmo, então, era o primeiro a detestar os meus atos. Era apenas a degradação da minha vontade e da minha inteligência, e foi provocada somente pelo desespero da minha situação. Mas isso passou.

\section{Ela se pintando.}

Ela - Ah passou! Agora o senhor é uma personalidade - um financista!

Ele - A senhora está se referindo à caixa de penhores?

Ela - Entenda como quiser.

Ela (saindo) - O senhor, porém, não me falou nada disso antes do casamento.

Narrativa - Vejam: na minha vida houve uma terrível circunstância externa, que me sufocava a cada dia e a cada hora, que foi a perda da reputação e a saída do regimento.

\section{Cena XVI}

INTIMAÇÃO

\section{Local - Quartel}

Iefímovitch - Ficamos sabendo que o senhor estava presente, no bufê do teatro, durante o intervalo, quando um hussardo começou a dizer alto, diante de todos os oficiais e do público ali presente, que o capitão do nosso regimento acabara de fazer um escândalo, no corredor e que estava bêbado. Por que o senhor não defendeu nosso capitão por ele ter sido tratado dessa forma insolente? E não interrompeu o tal hussardo com uma descompostura?

Ele - Mas e por que razão eu deveria? Se ele tem uma rixa com o nosso capitão, isso é um problema pessoal deles, por que é que eu ia me intrometer?

Iefímovitch - O problema não é pessoal, mas diz respeito ao regimento, e, como dos nossos oficiais apenas o senhor estava lá presente, demonstrou pela sua omissão que no 
nosso regimento há oficiais não tão escrupulosos da sua própria honra e da honra do regimento. Mas o senhor ainda pode consertar tudo isso se estiver disposto a tirar satisfações formais com o tal hussardo. Aceitando a se bater em duelo com ele!

Ele - Recuso-me a aceitar tal determinação. Não vou me submeter às vossas leis tirânicas.

Iefímovitch - Então o senhor prefere ser expulso do regimento como um covarde!

Narrativa - Recusei-me com orgulho e pedi baixa imediatamente. Saí com soberba, mas com o espírito espedaçado. Perdi a vontade e a razão. Nessa ocasião, coincidiu que o marido da minha irmã, em Moscou, esbanjou nosso patrimônio e fiquei na miséria. Eu poderia ter conseguido um emprego civil, mas depois de uma farda brilhante não queria ocupar um cargo em algum ponto da estrada de ferro. Pensei: vergonha por vergonha, desonra por desonra, decadência por decadência, e quanto pior, melhor - eis a minha escolha. Foram três anos de recordações tenebrosas. De repente morre, em Moscou, minha madrinha, deixando-me três mil rublos em testamento. Decidi meu destino, optando pela caixa de penhores, e, sem pedir perdão a ninguém, pensei: primeiro dinheiro, em seguida, vida nova, longe das antigas recordações - era esse o plano. Contudo, o passado sombrio, a reputação para sempre manchada de minha honra, afligia-me a cada minuto. Foi então que me casei.

\section{Cena XVII}

REVELAÇÃO

\section{Local - Caixa de Penhores}

Lukéria (recolhendo os jornais) - Senhor, a tia solteirona esteve aqui. Ela disse que quem está por trás de tudo isso é um tal de Iefímovitch, que foi seu antigo colega de regimento. A patroa já tem um encontro marcado com ele, e quem está comandando a coisa toda é Iulia Sansonovna, a viúva de um general. Agora é a casa dela que a patroa freqüenta.

Ele - Esse Iefímovitch, foi quem mais mal me causou no regimento, e esse descarado teve ainda a coragem de entrar no meu estabelecimento para falar a meu respeito.

Ele se veste toma o revólver e sai.

Lukéria - Senhor! (Faz o sinal da cruz)

\section{Cena XVIII}




\section{TRAIÇÃO}

\section{Local - Esconderijo}

Ele espiando o encontro entre Ela e Iefímovitch.

Ele - E como é que essa ingênua, essa monossilábica, sabe de tudo isso? Quanto brilho há nas suas palavras, que perspicácia nas respostas rápidas, que verdade na sua reprovação! E ao mesmo tempo uma inocência virginal. Somente por ódio de mim, poderia resolver-se a maquinar esse encontro, mas, agora, os seus olhos se abrem. Ela está louca para me ferir, mas, atrevendo-se a tal indecência, não suportou a desordem. E uma criatura como Ela, imaculada e pura, portadora de um ideal, poderia se deixar seduzir por um Iefímovitch ou qualquer uma desses imbecis da alta sociedade?

Ele invade o quarto com o revólver em punho e a convida a sair.

Iefímovitch - Ah...! Contra o sagrado dever do matrimônio eu não protesto, pode levála, pode levá-la! E fique sabendo que, embora um homem honrado não possa se bater em duelo com o senhor, mesmo assim, em respeito à sua dama, estou às suas ordens...Isso se o senhor aceitar correr o risco...

Ele - Ouviste o que ele disse?

Ele leva-a embora.

Narrativa - Por que é que eu a amava, por que é que eu lhe dava valor, por que é que eu havia me casado com Ela? Ah é claro que eu sabia o quanto Ela me odiava então, mas também sabia o quanto era pura.

\section{Cena XIX}

VINGANÇA

Local - Quarto

Ele a conduz pela mão até à casa. Ele coloca o revólver sobre a mesa. Ela, com um sorriso de zombaria lança-lhe um olhar de desafio. Ele tira a camisa e se deita. Ela senta numa cadeira e adormece ali. Ele acorda e vê a mulher em pé, com o revólver, avançando em sua direção. Ele fecha os olhos. Ela chega até a cama e se inclina sobre ele. Coloca o revólver nas têmporas dele. Ele faz um movimento convulsivo e abre os olhos, os dois se encaram um momento, o revólver continua em sua têmpora. Ele fecha rapidamente os olhos. Quando Ele torna a abri-los, Ela já colocou o revólver sobre a mesa. 
Narrativa - Os senhores vão perguntar: tinha eu alguma esperança de que me salvaria? Não tinha nenhuma esperança. Por que eu aceitava a morte? De que me serviria a vida depois de ter um revólver apontado contra mim por uma criatura que eu adorava? Além disso, eu sabia que entre nós nesse momento iniciava-se uma luta, um duelo terrível de vida ou morte, o duelo daquele mesmo covarde de ontem, expulso pelos companheiros por sua covardia. Eu sabia disso, e ela também sabia, caso tenha adivinhado a verdade, que eu não estava dormindo. Mas os senhores vão me perguntar novamente: por que é que não a salvei do crime? Ah, me fiz mil vezes essa pergunta cada vez que, com um frio na espinha, lembrava esse segundo. Mas naquele momento a minha alma estava imersa num desespero sombrio: eu estava destruído, então quem é que eu poderia salvar? Ao trazê-la para casa, eu pensava estar trazendo um amigo, eu necessitava muito de um amigo. Mas via que esse amigo, era preciso prepará-lo, completá-lo, e até mesmo dominá-lo. E podia eu explicar alguma coisa a essa menina toda cheia de preconceitos? Como é que eu podia, sem a ajuda casual dessa terrível catástrofe, ocorrida com o revólver, convencê-la de que não sou um covarde e de que no regimento me acusaram injustamente? Mas, ao suportar o revólver na cabeça, eu tinha me vingado de todo o meu passado sombrio. E, ainda que ninguém tenha ficado sabendo daquilo, Ela ficou sabendo, e isso era tudo para mim, porque Ela mesma era tudo para mim! Aos olhos dela eu já não podia ser um patife, um covarde e, sim, talvez, apenas um homem esquisito, mas agora também esse pensamento, nem me desagrada tanto: esquisitice não é defeito, ao contrário, às vezes até atrai o caráter feminino.

\section{Cena XX}

\section{ENIGMA}

\section{Local - Sala}

Ele entra na sala e aceita dela uma xícara de chá, lança-lhe um olhar, Ela sorri palidamente, com jeito interrogativo.

Ele (para si) - Então quer dizer que ainda está em dúvida e está se perguntando: “Ele sabe ou não sabe, Ele viu ou não viu?”. 
Narrativa - Comprei uma pequena cama de ferro e um biombo. Ela entendeu que eu “tinha visto tudo e sabia de tudo”. À noite Ela foi se deitar em silêncio nessa sua nova cama: o casamento estava rompido, “está vencida, mas não está perdoada”. À noite teve febre e caiu em delírio.

\section{Cena X}

\section{PROVAÇÃO}

\section{Local - Quarto}

Ela passa seis semanas de cama.

Narrativa - Durante as seis semanas da doença, cuidamos dela dia e noite. Eu não poupava dinheiro, e até queria gastar com Ela. Quando Ela ficou fora de perigo, decidi adiar o nosso futuro. Pensava: Ela está abalada demais e arrasada demais. O que tinha acontecido era o suficiente para a minha tranqüilidade e para os meus sonhos. Aí está o mal, é que eu sou um sonhador e achava que Ela esperaria. Eu gostava de olhar para Ela furtivamente, mas durante todo o inverno não tinha percebido um único olhar seu para mim! Achei que isso fosse timidez. Além do mais, Ela tinha o ar de uma docilidade tão tímida, de tanta fraqueza depois da doença. Pensava, é melhor esperar e - "e de repente Ela mesma vai se aproximar de ti...” Aos meus olhos estava tão derrotada, tão humilhada, tão esmagada, que eu me atormentava de pena dela, embora a idéia da sua humilhação me agradasse. Agradava-me a idéia dessa nossa desigualdade.

\section{Cena XXII}

RECLUSÃO

\section{Local - Quarto}

A luz indica que vem chegando a primavera e o sol passa a iluminar o quarto. Ela está em sua mesa de trabalho, em sua nova atividade de costurar. Começa a tossir, Lukéria a socorre.

Narrativa - De repente, notei nela um estado de concentração. Não era silêncio, era já ensimesmamento. Surpreendeu-me que Ela tivesse ficado tão franzina, magrinha, o rostinho pálido, os lábios embranquecidos. 


\section{Ele fica na porta espreitando-a.}

Lukéria - O que o doutor disse?

Ele - Ele não a examinou muito - esses médicos são às vezes de uma negligência arrogante, apenas me disse que eram resquícios da doença.

Ela (com um sorriso incerto) - Mas eu estou bem. Estou muito bem.

Ele - Ele aconselhou, que, com a primavera, não seria nada mal fazer uma viagem para algum lugar à beira-mar ou, se não fosse possível, então simplesmente mudar para uma datcha. Disse que havia fraqueza ou algo assim.

Ela (séria) - Eu estou bem. Muito bem.

Ele (para si) - Ela enrubesceu, pelo visto de vergonha.

Narrativa - Ah, agora eu entendo: Ela sentia vergonha porque eu ainda me preocupava com Ela como um verdadeiro marido. Mas na época não entendi e atribuí o rubor à sua resignação. Uma venda funesta e terrível pendia diante de meus olhos e me cegava a mente. De repente, recuperei a visão e entendi tudo! Será que foi um raio de sol que acendeu na minha mente embotada o pensamento e a intuição? Não, foi uma veia entorpecida que começou de repente a vibrar, reanimou e iluminou toda a minha alma embrutecida e o meu orgulho demoníaco.

\section{Cena XXIII}

RESSURREIÇÃO

\section{Local - Caixa de Penhores / Quarto}

Ele está no caixa, Ela, sentada em sua mesa de trabalho, começa a cantar, com voz fraca, e ao elevá-la, esgarça-se. Ela pigarreia e volta a cantar bem baixinho.

Ele (Fica um tempo parado, perplexo. Para si.) - Pobre vozinha, tão fraca, esgarçou-se de dar pena. Está cantando, e na minha presença! Será que esqueceu que eu existo? Ele chega até à porta do quarto para observá-la. Desnorteado, pega o chapéu e chama Lukéria, que vem ajudá-lo a vestir o casaco.

Ele - Ela está cantando? É a primeira vez que ela canta?

Lukéria (olha-o sem entender) - Não, quando o senhor não está, às vezes ela canta.

Ele sai para a rua a esmo. 
Narrativa - Essa novidade causou em mim uma impressão espantosa. Sem saber o que estava fazendo, sai a andar sem rumo! Eu me lembro de tudo! Mas no meu coração começou de repente uma espécie de êxtase. A pobre notinha trincada voltou a soar na minha alma. Estava caindo, estava caindo a venda dos meus olhos! (Voltando a ouvir a voz) - Se começou a cantar na minha presença, então se esqueceu de mim! - Isso é evidente e terrível. Isso era o que o coração sentia. Mas o êxtase irradiava-se na minha alma dominando o pavor. Onde eu tinha estado durante todo o inverno? Tinha eu estado junto da minha alma?

\section{Cena XXIV}

REVELAÇÃO

Local - Quarto

Entra precipitadamente no quarto, ela está no mesmo lugar, levanta a cabeça e o olha indiferente. Ele aproxima-se e toma suas mãos..

Ele - Vamos conversar... diga alguma coisa... Sabe... até hoje eu quase nunca te ouvi cantar, a não ser quando ainda brincávamos de tiro ao alvo. A tua voz, então, era bastante forte, sonora, agradável e sadia. Agora a cançãozinha estava tão fraquinha, como se na tua voz houvesse alguma coisa trincada, como se estivesse doente.

Ela o olha com severidade e espanto. Ele cai aos seus pés, Ela dá um salto, Ele a pega pelas mãos e beija seus pés. Ela começa a olhar, tentando entender, apreensiva. Depois começa a rir, com um misto de choro.

Ele - (balbuciando) Eu te amo, me deixa beijar o teu vestido... adorar-te, assim, a vida inteira...Tu não imaginas o que eu suportei, gemendo ao teu lado durante a doença. Eu gemia surdamente e sufocava os gemidos no meu peito. Eu não podia conceber nem sequer supor que tu morresses sem saber de tudo.

Ela - O senhor se acalme! Chega, não se torture!

Ele - Embora tivesse rompido o casamento ao comprar a cama e o biombo, jamais, jamais, pude ver-te como uma criminosa. O meu ódio jamais poderia amadurecer e se arraigar na minha alma. E não porque julgasse levianamente o teu crime, e sim porque tinha a intenção de te perdoar tudo, já desde o primeiro dia.

Ela começa a tremer e a soluçar, tem um ataque de histeria. Ele a carrega para a cama.

Ele - A tua voz está tão trincada, vou levar-te para Bolonha, para tomar banhos de mar e depois começaremos vida nova! 


\section{Ela chora.}

Ela - E eu pensava que o senhor me deixaria assim...!

Ele - Eu não vou te perguntar mais nada, mais nada - não me responde nada, me ignore completamente, e me deixe apenas te adorar, te olhar do meu canto, faça de mim o teu objeto.

Ele a faz dormir, fica ao seu lado a noite inteira. Lukéria permanece ali vigiando

Ele - Lukéria, vá se deitar, amanhã vai começar algo inteiramente novo. (para si)

Amanhã Ela vai acordar, e eu vou lhe dizer tudo, e Ela vai compreender tudo.

Narrativa - E eu acreditava nisso cegamente, apesar de ver em seus olhos um severo espanto e perceber sua silenciosa indagação: “Então o senhor ainda quer amor? Amor?". "E eu pensava que o senhor me deixaria assim", - ah, essas foram as suas mais importantes palavras e as mais esclarecedoras para mim naquela noite, como se elas me dessem uma punhalada no coração! Ah, a idéia de uma menina de dez anos! E acreditava mesmo e acreditava realmente que tudo ficaria assim: Ela na sua mesa, eu na minha, e assim nós dois, até os sessenta anos. E, de repente - aqui chego eu, o marido, e o marido precisa de amor! Ah, que equívoco, ah que cegueira a minha! Essas palavras me explicaram tudo, tudo, mas enquanto Ela estava diante dos meus olhos eu tinha uma esperança incontida e estava terrivelmente feliz. O principal aqui é essa viagem à Bolonha. Não sei por que só pensava que Bolonha - era tudo, que em Bolonha encontrava-se algo definitivo. "Para Bolonha, para Bolonha! Eu esperava alucinado pelo amanhecer".

\section{Cena XXV}

\section{CONFISSÃO}

\section{Local - Quarto}

\section{Amanhece.}

Ele - Eu quero te dizer que durante todo o inverno não fiz outra coisa senão estar certo do teu amor. Veja, até aquela catástrofe com o revólver, a perda da reputação e a saída do regimento me sufocavam a cada dia e a cada hora. Havia uma injustiça tirânica contra mim. È verdade que meus companheiros não gostavam de mim por causa do meu caráter difícil e, talvez, ridículo. Ah, jamais gostaram de mim, nem mesmo na escola. O caso do regimento, embora fosse uma conseqüência do desafeto que me votavam, sem dúvida teve um caráter acidental. A caixa de penhores existe apenas como degradação 
da minha vontade, da minha razão, uma idéia pessoal de autoflagelação e arrogância. No bufê eu realmente me acovardei, por causa do meu caráter, das minhas inseguranças: impressionou-me o ambiente. Acovardei-me não com o duelo, e sim por medo de parecer ridículo. Só que depois já não queria reconhecer isso e comecei a atormentar a todos, e por isso te atormentei também, e me casei para te atormentar.

Ela - O senhor está exagerando... o senhor está se torturando!

Ele - Ah, a primavera chegou, vamos para Bolonha! Lá está o sol, lá está o nosso novo sol! Fecharei a casa de penhores, passarei o negócio para Dobronrávov. Nós podemos distribuir tudo entre os pobres e ficar só com os três mil iniciais, herdados da minha madrinha, com os quais viajaremos para Bolonha, para depois voltarmos e começarmos uma nova vida de trabalho. Vamos para Bolonha, vamos para Bolonha!

\section{Ela sorri.}

Ele - Eu te considero, sem comparação, sem comparação, mais culta e mais desenvolvida que eu.

Ela (constrangida) - O senhor está exagerando.

Ele - Eu me deleito com a tua conversa. Eu me lembro do êxtase que tive quando, estava atrás da porta, ouvindo o duelo da inocência com aquela besta do Iefímovitch, e como eu me deliciei com a tua inteligência, com a agudeza do teu espírito de uma tal simplicidade infantil...

Ela (chora) - Eu sou uma criminosa, eu sei disso, o meu crime me atormentou durante todo o inverno, e ainda agora me tortura... eu valorizo muito a sua generosidade... eu vou respeitar o senhor, serei a sua fiel esposa.

\section{Cena XXVI}

\section{CELEBRAÇÃO}

Ele levanta de um salto e a abraça, beijando-lhe o rosto e os lábios. Cena imagética.

Narrativa - Eu a beijava como marido, pela primeira vez depois de uma longa separação. É verdade, verdade incontestável que eu cometi um erro, talvez muitos erros. Precipitei-me, demais, mas a confissão era necessária, imprescindível - era mais que uma confissão! Não ocultei nem sequer aquilo que até de mim mesmo vinha ocultando a vida inteira 


\section{Cena XXVII}

\section{LIBERTAÇÃO}

\section{Local - Quarto}

Lukéria vem até o quarto, vê o ícone fora do lugar.

Lukéria - O que está fazendo senhora?

Ela - Nada, Lukéria, vá embora... Fique, Lukéria

\section{Aproxima-se de Lukéria e a beija.}

Lukéria - A senhora está feliz?

Ela - Sim, Lukéria.

Lukéria - Há tempo, senhora, que o patrão deveria ter-lhe pedido perdão... Graças a

Deus fizeram as pazes.

Ela - Está bem, pode ir. Vai Lukéria!

Ela sorri de um jeito estranho. Lukéria sai. Ela está junto à janela de costas, segurando o ícone, quando Lukéria entra.

Lukéria - Está frio, senhora, não vá pegar um resfriado!

Ela ouve, faz que vai se virar e dá um passo adiante, aperta o ícone e se joga da janela.

Lukéria - Senhora, senhora!

\section{Cena XXVIII}

\section{SUPLICA CÓSMICA}

\section{Local - Rua / Caixa de Penhores}

Ele encontra-a morta no pátio. Lukéria se aproxima.

\footnotetext{
Narrativa - Para que fui sair ainda há pouco... os nossos passaportes para a viagem... Ah meu Deus! Se eu tivesse voltado cinco minutos antes. E agora essa multidão diante da nossa porta. Ah meu Deus!

Eles não tiram os olhos de mim. Todos ficam falando coisas: "saiu da boca uma gotinha de sangue, uma gotinha, uma gotinha!”.

Ah, crueldade, ah, absurdo! Para que essa mulher foi morrer!?

Eu sei, eu sei, não adianta ficar quebrando a cabeça: fez muitas promessas, teve medo de não poder cumpri-las - é evidente.
} 
Por que ela foi morrer? Eu a teria deixado assim, se ela quisesse. Não, não é nada disso. Foi simplesmente porque comigo precisava ser honesta; se é para amar, então é amar por inteiro, e não como teria amado o comerciante. E, como ela era casta demais, pura demais para concordar com o amor que necessitava o comerciante, não quis me enganar com um meio-amor. Muito honesta mesmo, aí é que está. E eu que queria infundir-lhe grandeza de coração. Idéia estranha!

Será que ela me desprezava? Ah, e daí que me desprezasse, - contanto que estivesse viva, viva! Agora não deixo Lukéria ir embora por nada desse mundo!

Lukéria - Senhor! Eu não vou mais ficar morando aqui nessa casa, assim que a patroa for enterrada, vou -me embora.

Nem Lukéria pode gostar de mim. O mais lastimável é que tudo não passou de um acaso. Agora, de novo os cômodos vazios, de novo eu sozinho. Não há ninguém eis a desgraça!

Se pelo menos tivesse deixado um bilhete... Ela ainda poderia ter vivido comigo. Cheguei atrasado!

Como Ela está franzina no caixão, como se afilou o seu narizinho! Os cílios parecem setas. E do jeito que caiu não esmagou e não quebrou nada! Só essa "gotinha de sangue". E se fosse possível não enterrá-la? Oh! Não, levá-la embora é quase impossível! Delírio, aí é que está o delírio, eu a esgotei! Foi isso... Queria rezar, mas não consigo - o que é que há para se rezar aqui - tudo é um pecado só!

O que são para mim agora as vossas leis? De que me servem os vossos usos, os vossos costumes, a vossa vida, o vosso estado, a vossa fé? Que me julgue o vosso juiz, que me levem para o vosso tribunal público, e eu vou dizer que não reconheço nada. $O$ juiz vai gritar: “Cale-se, oficial!” E eu vou lhe gritar: “Onde está agora o poder que me obriga a obedecer-lhe?".

Por que a tenebrosa teimosia destruiu aquilo que me era mais caro que tudo?

Cega, cega! Está morta, não pode ouvir! Tu não sabes com que paraíso eu teria te cercado. O paraíso estava na minha alma, eu o teria plantado em volta de ti! Bem, tu não me amarias - e daí, o que importa? Ah, se Ela abrisse os olhos uma única vez! Se me lançasse um olhar, como ainda há pouco, quando estava diante de mim e jurava que seria uma esposa fiel! Ah, num olhar ela teria entendido tudo! 
Ah, ignorância! Os homens estão sozinhos na terra - essa é a desgraça! Dizem que o sol nasce para todos. Olhem para ele, por acaso ele não é um cadáver? Tudo está morto, e há cadáveres por toda a parte. Os homens estão sozinhos, e em volta deles o silêncio - eis a terra! "Homens, amai-vos uns aos outros”. De quem é esse mandamento?

As suas botinhas estão junto da cama, como se esperassem por ela... não, é verdade, quando a levarem embora, o que vai ser de mim? O que vai ser de mim...! 


\section{ANÁLISE ATIVA DA ADAPTAÇÃO DA NARRATIVA DE A DÓCIL}

Levados pela complexidade da novela A Dócil, de Dostoiévski, a qual apresenta uma estrutura cíclica, peculiar, com dois níveis, o narrativo e o dramático, optamos por analisá-los em separado, porém sem que o elo entre ambos se perca. Como já foi mencionado, a história é revelada pelo herói através de um mergulho em sua autoconsciência, sendo que é nessa reflexão por meio de seus propósitos que decifraremos a idéia geral da obra, o superobjetivo e a linha transversal de ação do herói dentro da tragédia, ou seja, da narrativa .

O nível dramático será analisado em seus aspectos gerais, particulares e singulares, definindo primeiramente os grandes acontecimentos da história: o inicial, fundamental, central e final ou principal, com as respectivas circunstâncias que lhe dão origem, o superobjetivo e a linha transversal de ação das personagens. Em seguida será feita uma análise detalhada dos acontecimentos seqüenciais que compõem a história do relacionamento do casal que surge como resultado do ato de reflexão, que emerge da memória, do passado do herói.

Idéia da narrativa: A tragédia leva o herói à busca da verdade, através da imersão na autoconsciência, que o leva a entrar em contato com a real verdade, o que resulta no reconhecimento de seus erros e da crueldade da mentalidade do mundo que ele representa alcançando assim a purificação e a elevação de seus sentimentos e da sua vida mental e espiritual.

O herói, após o suicídio da mulher, reflete sobre seus atos, toma consciência do mundo do qual ele é o seu representante típico, o que leva assim, ao enfraquecimento desse universo e de suas leis destruidoras. Ele, além de ter empurrado a heroína para a morte, destruiu suas próprias possibilidades de felicidade e sua almejada inclusão na comunidade humana.

Superobjetivo do Oficial/Agiota dentro da tragédia: Decifrar o enigma da morte suicida da mulher, a fim de esclarecer a verdade para si mesmo e suavizar sua alma atormentada.

Linha Transversal de ação do Oficial/Agiota dentro da tragédia: Luta para decifrar o enigma do suicídio da mulher por meio de um confronto ininterrupto com sua consciência e chegar à verdade sobre o mesmo. 


\section{ANÁLISE ATIVA DOS GRANDES ACONTECIMENTOS DA ADAPTAÇÃo DE A DÓCIL}

Idéia: Num mundo dominado pela mesquinhez, pelo egoísmo e por uma mentalidade utilitarista e predatória que caracterizam a prevalência das relações de poder, a luta pela liberdade e a sua afirmação como valor primordial do ser humano leva a heroína, jovem, plena de sonhos e ideais, à autodestruição, como único caminho possível encontrado para alcançar a liberdade.

A heroína, esgotada em todas as suas forças vitais, encontra no suicídio uma forma de libertação do mundo que a oprime e que a leva ao sofrimento. Não se deixando submeter às ordens que dominam esse universo constituído, rompe com as suas regras e leis e, num ato heróico de desobediência ao mesmo, encontra no suicídio a salvação.

Tema: Independência e liberdade, condições necessárias para a realização das potencialidades humanas, para a felicidade.

Superobjetivo do Oficial/Agiota: Domesticar a esposa para ter o seu reconhecimento e obter a reintegração na comunidade social e humana como forma de alcançar a felicidade. A máxima do herói: “Os fins justificam os meios” - Mefistófeles.

Linha Transversal da contra-ação carregada pelo Oficial/Agiota: Luta para impor valores egoístas, mesquinhos e exercer o poder, o domínio sobre a esposa, como meio de alcançar a felicidade.

Superobjetivo da Dócil: A busca de realização afetiva, pessoal e de independência e liberdade para alcançar a felicidade.

Linha Transversal de Ação da Dócil: Luta para realizar suas aspirações afetivas e pessoais e afirmar seus valores de independência e liberdade.

Circunstâncias Dadas do Universo Inicial da obra, contidas no grande círculo: Repetimos que o universo da obra é caracterizado pela soma de todas as circunstâncias que compõem esse contexto sob os aspectos filosóficos, culturais, políticos, sociais, econômicos e pessoais. O universo inicial que permeia a história do relacionamento do casal, revivida pelo Oficial/Agiota, após o suicídio da mulher, nós o caracterizamos assim: predominância de interesses egoístas e mesquinhos movidos pelo bem material que visa ao maior lucro, que se dá em cima da desgraça alheia, onde a troca não é justa e igualitária. 
Vemos, por um lado, um mundo racional, utilitarista e predatório, representado pelos agiotas e o comerciante, caracterizado, sobretudo, na figura do Oficial/Agiota, que, movido pela ganância em acumular dinheiro, reduz o ser humano ao cálculo em que o objeto representa somente um valor material; por outro lado, há pessoas necessitadas, que, para sobreviverem, entregam seus objetos, que têm um valor afetivo, espiritual, impagável. Esse universo transcorre à margem da sociedade constituída legalmente, representa o mundo dos excluídos, dos marginalizados, dos ressentidos socialmente, mas não deixa de ser um microcosmo da grande esfera dessa sociedade constituída.

Quem carrega o lado "obscuro" desse universo inicial, caracterizado pela mentalidade depredatória, utilitarista, mesquinha, egoísta e escravocrata, são os agiotas, o vendeiro, as tias e Iefímovitch. O vendeiro quer comprar a Dócil, as tias a tratam como escrava e querem vendê-la, os agiotas em geral são insensíveis às suas necessidades e, particularmente, o Oficial/Agiota a vê como uma presa fácil para ser submetida ao seu domínio, Iefímovitch quer se divertir por algumas horas, tornando-a seu objeto sexual.

O Oficial/Agiota carrega a contra-ação representada pelo universo inicial que na II Parte do espetáculo se fortalece e surge claramente caracterizada como “Dominação”. A linha transversal de ação, carregada pela Dócil, emerge no acontecimento “O Pacto” que se dá pelo processo de transformação do pedido de casamento.

Acontecimento Inicial (Universo Inicial): É concretizado cenicamente por um ou mais acontecimentos. Em A Dócil, abrange todos os acontecimentos que compõem a I parte, que nomeamos de “A Conquista”, e vai até o "Pacto", somando um total de sete acontecimentos, com as respectivas circunstâncias que lhes dão origem.

Principal Circunstância Dada: Nós a determinamos como sendo a aceitação do pedido de casamento por parte da Dócil. Essa circunstância vai gerar o acontecimento que dá origem à história, “O Pacto”, pois sem ela a história não existiria. Entendemos que essa circunstância é a que dá início à história.

Acontecimento Fundamental: É o acontecimento que inicia a história originado pela principal circunstância dada. Ele acontece no pedido de casamento, que sofre uma transformação qualitativa pela entrada da principal circunstância dada, que origina o acontecimento “O Pacto”. Nele são determinadas as exigências e as regras do compromisso estabelecido de ambas as partes. 
Circunstância que gerou o Acontecimento Central: A tomada de consciência da sua incapacidade em corresponder aos apelos apaixonados do marido e a impossibilidade de violar a sua natureza liberta e seus valores espirituais.

Acontecimento Central: “Libertação”. Neste acontecimento todas as forças dramáticas se conjugam para um ponto, o ápice da história, o suicídio da heroína. Aqui cessa a luta iniciada por ela, através da linha transversal de ação, que percorreu todos os acontecimentos, mas que emerge claramente em “O Pacto" e se impõe durante todo o processo da história, até o seu término, sendo que, com a morte agarrada ao ícone da virgem Ela resgata a sua identidade e seus valores espirituais sufocados.

Circunstância que gerou o acontecimento Final ou Principal: O suicídio da Dócil.

\section{Acontecimento Final ou Principal: “Súplica Cósmica”}

Esse acontecimento que representa ao mesmo tempo o início, da tragédia em que o Oficial/Agiota encontra a mulher morta, é também o fechamento cíclico da história, em que são mostradas a atitude do herói diante da tragédia e o resultado dessa viagem interior em sua autoconsciência. A trajetória que ele percorreu em busca da verdade o leva a tomar consciência da co-responsabilidade pelo suicídio da mulher, o que "Ihe eleva avassaladoramente o coração e a inteligência”. O epílogo nós nomeamos de “Súplica Cósmica”, pois entendemos que nele há o apelo e as indagações para poder entender o enigma, não só do suicídio, mas do destino e, talvez, "aceitar” seus desígnios. É também um grito de rebeldia por essa “ofensa” e uma despedida inconformada, em que se dá um processo de reconhecimento da sua condição de solidão e da destruição dos seus sonhos.

\section{ANÁLISE ATIVA DOS ACONTECIMENTOS SEQÜENCIAIS DA ADAPTAÇÃO DE A DÓCIL}

\section{I - Acontecimento: Ritual Fúnebre}

Palavras-chave: "Ah, crueldade, ah, absurdo! Para que essa mulher foi morrer!?".

Esse acontecimento é representado por um cortejo ritualístico em que o Oficial/Agiota traz nos braços a mulher morta, toda de branco, vestida de noiva, que acabara de encontrar morta no pátio, e a deposita numa mesa no interior da caixa de penhores. Diante do desespero desse universo trágico, o herói inicia uma revisão do seu 
passado através de um mergulho em sua autoconsciência, trazendo à memória a sua relação com a suicida, revivendo-a no presente trágico. "Se querem saber, Ela veio a minha casa”.

\section{PARTE I - Conquista (Universo Inicial)}

\section{II - Acontecimento: Penhora de Objetos}

Palavras-chave: "Calada! Os outros discutem, insistem, regateiam para que lhes dêem mais. Essa não, aceita o que derem”.

Objetivo do acontecimento: Mostrar o universo de uma casa de penhores, onde predomina o lucro.

Circunstância dada que gerou o acontecimento: A necessidade de conseguir dinheiro para pagar anúncios de jornal a fim de alcançar a independência e a liberdade.

Objetivo dela: Conseguir o dinheiro necessário com objetos que possuem grande valor afetivo, mas pouco valor material.

Obstáculos dela: O desconhecimento das regras que dominam o mundo da agiotagem. O ambiente não adequado para uma adolescente, a ingenuidade, o apego afetivo aos objetos, o desconhecimento do valor real dos objetos.

Ação dela: Observar, valorizar, esperar, calar, lamentar, refletir, entregar, surpreender, conformar, desprender-se.

Objetivo dele: Tirar o máximo de lucro dos objetos.

Obstáculos dele: Ela é uma cliente diferente para aquele ambiente: jovem, ingênua, pobre, calada - "aceita o que derem”.

Ação dele: Desvalorizar os objetos, tirar proveito.

\section{III - Acontecimento: Humilhação}

Palavras-chave: “Os seus olhos azuis, grandes e pensativos como que pegaram fogo". "Esse foi o meu primeiro pensamento sobre ela, num sentido particular".

Objetivo do acontecimento: Mostrar o poder e o desdém dele sobre a penhora de objetos que não sejam de ouro, sem valor, e a reação da indefesa e pobre órfã, seu orgulho e a sua dignidade.

Circunstância dada que gerou o acontecimento: Querer penhorar um objeto não adequado, sem valor para os penhoristas. 
Objetivo dela: Obter a soma de dinheiro necessária para poder pagar os anúncios de jornal.

Obstáculos dela: A recusa do objeto pelos outros penhoristas, a qualidade do objeto, o abrigo próprio que a protege, o orgulho, a dignidade.

Ação dela: Valorizar, defender, atacar, arrancar, fugir.

Obstáculos dele: A atitude dela, o orgulho, a ação inesperada dela, a ofensa, a excitação e a reação inesperada dele.

Ação dele: Desdenhar, zombar, provocar, surpreender, regozijar, descobrir.

\section{IV - Acontecimento: Revide}

Palavras-chave: “O que faz a pobreza! Fui cruel! Dei-lhe uma alfinetada! Será que essa vitória sobre ela vale dois rubros?”.

Objetivo do acontecimento: Mostrar a mudança de atitude do Oficial/Agiota gerada pelo seu interesse em conquistar a heroína mediante a aceitação e a supervalorização do objeto.

Circunstância dada que gerou o acontecimento: A reação inesperada dela, causada pelo desdém relativo à “jaquetinha”, despertou o interesse amoroso do Oficial/Agiota pela Dócil, tornando-se Ela objeto de sua cobiça.

Objetivo dele: Chamar atenção sobre si e mostrar o seu poder.

Obstáculos dele: A imprevisibilidade dela, a mesquinhez, o lucro.

Ações dele: Mostrar seriedade, repreender, acusar, informar, valorizar, humilhar, doar, festejar, decidir.

Objetivo dela: Conseguir que Ele aceite a penhora do objeto.

Obstáculos dela: O orgulho, a dignidade, ter que suportar as humilhações. O “escândalo” da “jaquetinha”.

Ações dela: Valorizar, silenciar, admirar, ignorar, aceitar, apressar.

\section{V - Acontecimento: Suborno}

Palavras-chave: "Investiguei todas as circunstâncias da vida dela”.

Objetivo do acontecimento: Mostrar quais os meios que Ele utiliza para obter informações, para saber e conhecer quem era Ela.

Circunstância dada que gerou o acontecimento: O total desconhecimento de seu objeto de interesse.

Objetivo dele: Investigar a vida da Dócil, obter informações sobre Ela. 
Obstáculos dele: Desconhecer Lukéria. Subornar.

Ação dele: Seguir, espiar, abordar, interessar, seduzir, subornar, indagar, valorizar, indignar, agradecer.

Objetivo de Lukéria: Encontrar uma saída para a situação crítica da Dócil.

Obstáculos de Lukéria: As tias, a integridade e descrição da Dócil, o Oficial/ Agiota.

Ação de Lukéria: Indagar, desconfiar, contar, aceitar, espreitar, esquivar, segredar.

\section{VI - Acontecimento: Prova}

Palavras-chave: “Eu esperava a sua chegada com impaciência. Eu já pressentia quando Ela estava por vir”.

Objetivo do acontecimento: Mostrar as estratégias do Agiota no processo de sedução de seu objeto de desejo através de revelações, provocações e constrangimentos a que Ele submete a heroína.

Circunstância dada que gerou o acontecimento: O conhecimento que Ele obteve da vida e da situação crítica da Dócil.

Objetivo dele: Assediar e intimidar a Dócil, usando as informações que Ele possui sobre a vida dela.

Obstáculos dele: O temperamento dela, o silêncio, a imprevisibilidade, o tipo arredio, discreto, e o recato dela.

Ação dele: Agradar, elogiar, indagar, forçar, submeter, constranger, invadir, revelar, aconselhar, provocar, experimentar, desafiar.

Objetivo dela: Conseguir a quantia necessária para poder pagar os anúncios de jornal.

Obstáculos dela: O último objeto do pai e que tem muito valor afetivo, os constrangimentos.

Ação dela: Suportar, responder, livrar, fugir, conjeturar, calar.

\section{VII - Acontecimento: Penhora Espiritual}

Palavras-chave: “Foi aí que eu descobri que Ela era boa e dócil” "Agora quero apenas recordar como então tive essa intenção, banquei o importante diante dela e cresci a seus olhos”. 
Objetivo do acontecimento: Mostrar o jogo de sedução utilizado pelo herói, através da figura de Mefistófeles confrontada à imagem sagrada, e como Ele consegue alterar a sua imagem, despertando o interesse da Dócil ao citar Goethe.

Circunstância dada que gerou o acontecimento: A situação crítica em que a Dócil se encontra, prestes a ser comprada pelo vendeiro, o que a obriga a empenhar o último bem que lhe resta, o seu maior bem espiritual, a imagem sagrada. Conjugada à confirmação de que Ela corresponde ao ideal de mulher que Ele busca.

Objetivo dele: Seduzir e impressionar a Dócil, despertando o seu interesse sobre Ele e que Ela o veja, o dimensione para além da profissão que Ele exerce, como um homem culto e elevado.

Obstáculos dele: A profissão, o caixa, a idade dele, o comportamento dela, o caráter e impetuosidade dela, a idade dela.

Ação dele: Provocar, seduzir, surpreender, revelar, agradar, repreender demonstrar, desafiar, comover, ofender.

Objetivo dela: Obter a garantia de que a imagem será resgatada, que Ele entenda e compreenda a importância da imagem para Ela.

Obstáculos dela: A imagem sagrada, que representa o seu maior valor espiritual. Receio de não poder resgatar a imagem dentro do prazo.

Ação dela: Valorizar, surpreender, provocar, instigar, lamentar.

\section{VIII - Acontecimento: O Pacto}

\section{(Acontecimento Fundamental)}

Palavras-chave: “O mais importante é que eu já a olhava como minha e não duvidada do meu poder”.

Objetivo do Acontecimento: Mostrar como Ele utiliza a situação crítica da Dócil e consegue impressioná-la e convencê-la a aceitar o pedido de casamento.

Circunstância dada que gerou o acontecimento: A certeza de que Ela não tem mais escolha, o que lhe confere poder sobre ela, confirmado pela situação anterior.

Objetivo dele: Que Ela o aceite como noivo.

Obstáculos dele: A dúvida, a pureza e integridade dela, a rejeição, o vendeiro, as tias, a profissão dele, a diferença de idade entre eles.

Ação dele: Valorizar, elogiar, concordar, convencer, persuadir, seduzir, deslumbrar, combinar, estipular, convencionar. 
Objetivo dela: Escolher o melhor entre o Oficial/Agiota e o vendeiro para a independência e liberdade que Ela almeja.

Obstáculos dela: A idade, a dúvida, a profissão e o desconhecimento dele, os sonhos de felicidade e independência, o romantismo.

Ação dela: Desobedecer, refletir, ponderar, decidir, exigir, pactuar.

Objetivo de Lukéria: Salvar a Dócil das tias e do casamento com o vendeiro.

Obstáculos de Lukéria: O orgulho da Dócil, o temperamento dela, a presença do vendeiro, as exigências das tias, a falta de enxoval, a dívida das tias, as imposições do Oficial/Agiota.

Ação de Lukéria: instigar, atiçar, pressionar, agradecer, valorizar, aconselhar, confessar.

Observação: Nesse acontecimento surge a principal circunstância dada: “a aceitação do pedido de casamento”, que dá origem ao acontecimento fundamental, o qual ocorre dentro do pedido de casamento como um processo de desenvolvimento e transformação pela entrada da Principal Circunstância Dada - “a aceitação do pedido” - que dá início, em primeiro plano, ao acontecimento fundamental chamado: “O Pacto”, no qual inicia o tema, pois, se a Dócil não aceitasse o pedido do Oficial/Agiota, não haveria essa história. Neste acontecimento ocorrem as imposições e o conhecimento das regras de “O Pacto” e as exigências de ambas as partes.

\section{IX - Acontecimento: O Casamento}

Palavras-chave: “Agradava-me saber que eu tinha quarenta e um anos e Ela mal fizera dezesseis. Isso me cativava, essa sensação de desigualdade era muito doce, muito doce".

Objetivo do acontecimento: Mostrar a concretização da conquista e o início da almejada reinclusão social de ambos. Neste acontecimento imagético, é dado realce ao ritual de iniciação, a importância do rito de passagem, o seu significado social, cultural espiritual e pessoal.

\section{PARTE II - Domínio}

\section{X - Acontecimento: Ritual de Iniciação}

Palavras-chave: "Não mantenho cães enormes nem criados fortes, como fazem os outros penhoristas, por isso tenho uma arma para autodefesa”. 
Objetivo do Acontecimento: Mostrar a passagem de um conhecimento do marido para a esposa, a Dócil, e a sua iniciação e integração na perigosa atividade de agiota.

Circunstância dada que gerou o acontecimento: A promessa feita pelo Oficial/Agiota, durante o “O Acordo”, de empossá-la nas atividades da caixa de penhores.

Objetivo dele: Integrar a esposa no trabalho da caixa de penhores.

Obstáculos dele: Imaturidade, juventude e inexperiência dela, desconfiança dele, insegurança, a dúvida, o seu lado enigmático, a profissão obscura e violenta.

Ação dele: Esconder, decidir, ensinar, transmitir, ordenar, empossar, doar, afirmar.

Objetivo dela: Corresponder às expectativas na nova vida e no novo trabalho, buscando a afetividade e a igualdade com o marido.

Obstáculos dela: A arma, o desconhecimento da atividade, a severidade do marido.

Ação dela: Provar, experimentar, realizar, vibrar, brincar, divertir, aprender.

\section{XI - Acontecimento: Rotina}

Palavras-chave: “Ela viu num instante que nós somos diferentes e que eu sou um enigma e eu apostei nesse enigma”.

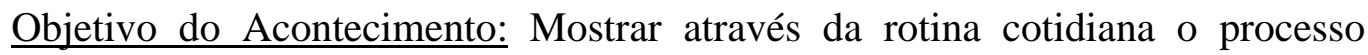
gradativo do aumento das tensões nas relações entre o casal. Esse acontecimento foi concretizado cenicamente através de uma mímesis coreográfica de movimentos precisos e repetitivos, sob o som rítmico do ábaco executado pela heroína.

Circunstância dada que gerou o acontecimento: A proposição secreta de um sistema pelo Oficial/Agiota.

Objetivo dele: Colocar em prática o seu plano secreto, congelando os impulsos afetivos da esposa e mostrando a eficácia e a severidade da gerência e otimização das atividades externas e internas do caixa.

Obstáculos dele: Imaturidade, generosidade e entusiasmo juvenil dela, afetividade dela, os próprios impulsos e sentimentos dele.

Ação dele: Verificar, avaliar, recusar, controlar, vigiar, proteger-se, controlar-se, calar, paralisar. 
Objetivo dela: Corresponder às expectativas do marido, mostrando capacidade no novo trabalho, dedicação zelo e carinho.

Obstáculos dela: Inexperiência, insegurança, incompreensão das atitudes do marido, controle, severidade, autoridade, incomunicabilidade e rigidez afetiva do marido.

Ação dela: Executar, mostrar, observar, indagar, zelar, agradar, expor-se, acariciar, amansar.

\section{XII - Acontecimento: Arrebatamento I}

Palavras-chave: “A minha idéia consistia em responder aos arrebatamentos com o silêncio, dando logo um banho de água fria no seu entusiasmo”.

Objetivo do acontecimento: Mostrar o processo de domínio e domesticação do Oficial/Agiota sobre a esposa e as discordâncias entre o casal em nível afetivo e material.

Circunstância dada que gerou o acontecimento: O surgimento dos primeiros obstáculos para colocar em prática o sistema que Ele planejou, quando Ela decide tomar iniciativas profissionais, domésticas e afetivas independentes.

Objetivo dele: Que Ela adivinhe, por si só, as regras do jogo que Ele impõe.

Obstáculos dele: A inocência, a generosidade, a impetuosidade, a juventude, a independência e a busca de concretização do amor por parte da esposa. A idéia secreta do sistema e o não entendimento dela sobre o mesmo, o sentimento que Ele nutre por Ela, a necessidade de se controlar.

Ação dele: Vigiar, controlar, educar, moldar, aconselhar, proibir, punir.

Objetivo dela: Busca de afetividade e autonomia.

Obstáculos dela: A incógnita que Ele representa, o silêncio, a avareza e rigidez dele, a dignidade, inibição e orgulho dela.

Ação dela: Valorizar, amenizar, rebelar, aceitar, desconfiar, renunciar, tolerar, relevar.

\section{XIII - Acontecimento: Arrebatamento II}

Palavras-chave: "Queria que Ela descobrisse por si mesma, sem mim, mas não pelas histórias dos canalhas, e desse valor”. 
Objetivo do Acontecimento: Mostrar as reações causadas pela insistência dele em permanecer dentro do enigmático sistema planejado por Ele, de domesticação, severidade, incomunicabilidade e acúmulo de dinheiro.

Circunstância dada que gerou o acontecimento: Chegam aos ouvidos da Dócil informações sobre a vida do Oficial/Agiota e boatos sobre a sua mesquinhez. Revelação de como os outros o vêem e o que pensam sobre ele.

Objetivo dele: Ser reconhecido pela esposa como um homem de valor.

Obstáculos dele: O mistério, o passado, os desafetos, as intrigas, a desconfiança dela, o egoísmo, o orgulho, a obsessão pelo dinheiro, a mesquinhez, o silêncio e a incomunicabilidade.

Ação dele: Rejeitar, defender-se, acusar, prender, calar, esperar.

Objetivo dela: Desafiar a tirania afetiva e material do marido.

Obstáculos dela: Respeito pelo marido, a incerteza sobre as intrigas, dignidade, a dúvida, a bondade.

Ação dela: Aconchegar, afagar, acariciar, rebelar-se, acusar, enfrentar, desafiar.

\section{XIV - Acontecimento: Deposição}

Palavras-chave: "Foi debaixo de severidade que a trouxe para casa. A juventude despreza o dinheiro, eu me agarrei ao dinheiro, teimei no dinheiro". "Uma mulher, ainda mais de dezesseis anos, tem de se submeter inteiramente ao marido".

Objetivo do Acontecimento: Mostrar o limite a que chegaram as desavenças e a intolerância entre o casal, causadas pela generosidade da esposa na avaliação dos objetos e pela atitude do marido diante da autonomia da esposa.

Circunstância dada que gerou o acontecimento: Desobedecendo à determinação do marido, Ela troca o medalhão pelo bracelete, atribuindo a este o mesmo valor, o que traz prejuízos consideráveis aos planos de acúmulo de dinheiro do marido.

Objetivo dele: Frear as ações financeiras independentes da esposa, reduzindo-a a um lugar subalterno na casa.

Obstáculos dele: Rebeldia, impetuosidade, imprevisibilidade, atrevimento dela, desobediência.

Ação dele: Acusar, ofender, esmagar, ferir, proibir, depor.

Objetivo dela: Insurgir-se contra o poder que a oprime resgatando a dignidade ofendida e pisoteada. 
Obstáculos dela: A ira dele, a sua condição de dependência material, o acordo entre ambos, a proibição.

Ação dela: Defender, justificar, rebelar, reagir, enfrentar, escarnecer, desafiar.

\section{XV - Acontecimento: Interrogatório}

Palavras-chave: "Uma mulher que ama vai endeusar até mesmo os vícios, os crimes do ser amado. Se o mais generoso dos homens tornou-se um agiota, quer dizer que havia motivos”.

Objetivo do acontecimento: Mostrar o enfrentamento entre a Dócil e o Oficial/Agiota, quando Ela exige a revelação da verdade sobre o seu passado mantido em segredo, a sete-chaves.

Circunstância dada que gerou o acontecimento : As informações que Ela colheu, ao sair de casa, sobre o passado do marido, as quais foram omitidas por Ele.

Objetivo dele: Justificar-se e defender-se das acusações sobre os acontecimentos do passado, argumentando que foi vítima de uma injustiça tirânica.

Obstáculos dele: Admitir a verdade. A descoberta que Ela fez sobre o seu passado. A incógnita do passado. O sofrimento pelo qual Ele passou, a vergonha, a humilhação. A perseguição do passado que volta, ferida aberta que Ele tentou esquecer. O abalo de sua autoridade e imagem diante dela. A dignidade e o valor dele. Admitir que Ele foi considerado covarde.

Ações dele: Calar, confirmar, justificar, defender-se, valorizar, convencer, amenizar, conter.

Objetivo dela: Ela quer saber toda verdade, dita por Ele próprio sobre as informações que obteve em relação ao seu passado obscuro.

Obstáculos dela: O equívoco dela em relação a Ele, aceitar a verdade, o desmoronamento do ideal, o desencanto, a transgressão de sua própria natureza.

Ações dela: Enfrentar, indagar, encurralar, cercar, pressionar, obrigar, saber, acusar, desdenhar, ironizar, cobrar, desprezar, humilhar.

\section{XVI - Acontecimento: Intimação}

Palavras-chave: “Na minha vida houve uma terrível circunstância externa, que me sufocava a cada dia e a cada hora, que foi a perda da reputação e a saída do regimento". 
Objetivo do acontecimento: Mostrar e elucidar o passado mais longínquo do herói configurado pelo presente acontecimento, que gerou o seu trauma inicial, o qual explica em parte as escolhas e o comportamento do Oficial/Agiota.

Circunstância dada que originou o acontecimento: A verdade sobre o passado, que veio à tona, e a volta do inimigo, que surge como um fantasma, a perseguir a vida presente do herói, impedindo-o de realizar seus planos e atingir a sua realização pessoal.

Objetivo do Agiota: Não se envolver em mazelas internas do regimento, em rixas pessoais da corporação, desacatando e desobedecendo à autoridade do mesmo. Não quer comprometimento com questões coletivas.

Obstáculos do Agiota: A insegurança, a omissão diante do incidente ocorrido, o dever, a moral, a honra, as regras do regimento, a perda da reputação, o orgulho.

Ações do Agiota: Omitir, reagir, recusar, negar, desacatar, desafiar, indagar, defender, desobedecer, excluir.

Objetivo do Iefímovitch: Obrigar o colega a assumir um dever em relação à defesa e à honra do regimento, desafiando-o a tomar uma atitude heróica, colocando em cheque a sua coragem, a fim de ridicularizá-lo.

Obstáculos do Iefímovitch: A omissão do Agiota, o caráter do Agiota, o desacato e a defesa do Agiota.

Ações do Iefímovitch: Surpreender, acusar, questionar, indagar, provocar, obrigar, ameaçar, ridicularizar, punir.

\section{XVII - Acontecimento: Revelação}

Palavras-chave: "Esse Iefímovitch foi o que mais mal me causou no regimento, $e$ esse descarado teve ainda a coragem de entrar no meu estabelecimento para falar a meu respeito".

Objetivo do acontecimento: Mostrar as providências tomadas pelo Oficial/Agiota sobre os atos insubordinados e independentes da Dócil.

Circunstância dada que gerou o acontecimento: $\mathrm{O}$ resultado do pagamento às tias por informações obtidas por meio da espionagem sobre as saídas da esposa.

Objetivo do Agiota: Saber onde e com quem a Dócil está se encontrando.

Obstáculos do Agiota: A fidelidade, o amor, o caráter e a dedicação de Lukéria com a Dócil.

Ações do Agiota: Escutar, cercar, pressionar, esbravejar, indagar, decidir, rebelar. 
Objetivo de Lukéria: Zelar pela reputação de sua senhora.

Obstáculos de Lukéria: A reação e atitude do Oficial/Agiota, a ameaça, o temor pela tragédia.

Ações de Lukéria: Revelar, suplicar, rezar.

\section{XVIII - Acontecimento: Traição}

Palavras-chave: "Somente por ódio de mim, poderia resolver-se a maquinar esse encontro, mas agora os seus olhos se abrem”.

Objetivo do acontecimento: Mostrar a verdade sobre a acusação de infidelidade da Dócil e a descoberta do Oficial/Agiota sobre a sua pureza, o seu caráter e integridade moral.

Circunstância dada que gerou o acontecimento: O conhecimento do encontro marcado entre a esposa, a Dócil, e o suposto “amante”, antigo colega de regimento e inimigo, Iefímovitch.

Objetivo do Agiota: Salvar a mulher das garras do inimigo.

Obstáculos do Agiota: Não ser percebido, a verdade, o autocontrole, a presença do inimigo do passado, a infidelidade.

Ações do Agiota: Esconder-se, vigiar, descobrir, espiar, admirar, vibrar, flagrar, invadir, enfrentar, proteger, recusar, ignorar, convidar, salvar.

Objetivo do Iefímovitch: Quer se divertir e desfrutar de um momento voluptuoso com a mulher do inimigo.

Obstáculos do Iefímovitch: A atitude da Dócil. O Oficial/Agiota.

Ações do Iefímovitch: Seduzir, cercar, envolver, convencer, agradar, provocar, desafiar.

Objetivo da Dócil: Descobrir e confirmar toda a verdade sobre o passado do marido, sobretudo sobre sua covardia, com o seu principal inimigo e responsável pela sua expulsão do regimento.

Obstáculos da Dócil: O encontro secreto, ser casada, a pressão de Iefímovitch, a volúpia de Iefímovitch, a fogosidade e impetuosidade dele.

Ações da Dócil: Jogar, seduzir, argumentar, desvencilhar-se, defender-se, escarnecer, indagar, escapar, obedecer, submeter-se. 


\section{XIX - Acontecimento: Vingança}

Palavras-chave: “Eu sabia que entre nós nesse momento iniciava-se uma luta, um duelo terrível de vida ou morte, o duelo daquele mesmo covarde de ontem, expulso pelos companheiros por sua covardia”.

Objetivo do acontecimento: Mostrar o ápice da crise no relacionamento do casal com o desmoronamento, o rompimento da idealização e o total desencantamento em relação ao amor, à confiança, à igualdade, à verdade, à coragem, à honra, à dignidade e à liberdade.

Circunstância dada que gerou o acontecimento: A confirmação de que Ele, realmente, era um covarde duas vezes, por não ter aceitado o duelo no regimento e, agora, negando-se ao desafio do rival para salvar a honra da mulher.

Objetivo do Agiota: Resgatar a sua dignidade e honra provando, para a Dócil, e sobretudo, para si mesmo, que Ele não é um covarde, testando a sua heróica coragem ao enfrentar o revólver na cabeça apontado pela esposa.

Obstáculos do Agiota: Aceitar a morte, suportar o revólver, simular que está dormindo, os sentimentos em relação a Ela.

Ações do Agiota: Provar, suportar, simular, fingir, sacrificar, resistir, autoimolar, vingar.

Objetivo da Dócil: Eliminar o marido covarde.

Obstáculos da Dócil: Os princípios - valores - morais e cristãos, a bondade.

Ações da Dócil: Convencer-se, refletir, planejar, observar, decidir, simular, esgueirar-se, tatear, silenciar, duvidar, fraquejar.

Objetivo da Lukéria: Certificar-se de que nada de mal aconteceu a sua senhora.

Obstáculos da Lukéria: a espera prolongada, o silêncio de ambos.

Ações da Lukéria: Esperar, rezar, recear, servir, zelar, dedicar, alegrar.

\section{PARTE III- Castigo}

\section{XX - Acontecimento: Enigma}

Palavras-chave: "Então quer dizer que ainda está em dúvida e está se perguntando: Ele sabe ou não sabe , Ele viu ou não viu?”.

Objetivo do acontecimento: Mostrar a dúvida de ambos sobre o conhecimento da tentativa de assassinato. 
Circunstância dada que gerou o acontecimento: A tentativa oculta de assassinato do marido.

Objetivo do Agiota: Quer saber se Ela tem certeza de que Ele viu o atentado.

Obstáculos do Agiota: O conhecimento do fato, a dúvida do que cada um sabe, o silêncio entre eles.

Ações do Agiota: Decifrar, observar, simular.

Objetivo da Dócil: Quer saber se Ele viu, se sabe que Ela tentou matá-lo.

Obstáculos da Dócil: A verdade, o que cada um sabe, o silêncio entre eles.

Ações da Dócil: Decifrar, interrogar, simular, disfarçar, servir, cumprir o ritual, a obrigação, de servi-lo.

Objetivo da Lukéria: Descobrir o que está acontecendo entre o casal.

Obstáculos da Lukéria: O silêncio enigmático, a descrição.

Ações da Lukéria: Observar, servir, deduzir, simular.

\section{XXI - Acontecimento: Provação}

Palavras-chave: “À noite ela foi se deitar em silêncio em sua nova cama: o casamento estava rompido. Ela está vencida, mas não está perdoada. À noite teve febre e caiu em delírio”.

Objetivo do acontecimento: Mostrar as conseqüências da transgressão da natureza moral, psíquica e física da Dócil, diante do reconhecimento de que Ela é uma criminosa, e o zelo do marido com a condenada.

Circunstância dada que gerou o acontecimento: A revelação de que "Ele tinha visto e sabia de tudo" sobre a tentativa de assassinato a partir da compra da "pequena cama de ferro e um biombo", que significam o rompimento do casamento.

Objetivo do Agiota: Prover todas as necessidades para poder salvar a mulher.

Obstáculos do Agiota: A racionalidade, a mesquinhez, o orgulho, o egoísmo dele, a debilidade e a permanência de febre dela, o ato dela querer eliminá-lo.

Ações do Agiota: Rezar, zelar, suplicar, prover, cuidar, proteger, acudir, remediar, espiar, olhar furtivamente, esperar, apiedar-se, espreitar.

Objetivo da Dócil: Lutar contra a morte.

Obstáculos da Dócil: A febre, a debilidade, a culpa, a condição atual que Ela ocupa na casa, a gravidade da doença, a constituição física debilitada.

Ações da Dócil: Combater, aquietar, rezar, apaziguar, acalmar, lutar.

Objetivo da Lukéria: Salvar, cuidar e amparar a Dócil. 
Obstáculos da Lukéria: A natureza debilitada da Dócil, a situação à qual está reduzida na casa, o Oficial/Agiota.

Ações da Lukéria: Zelar, cuidar, rezar, velar, acudir, remediar, consolar, proteger fortalecer, apiedar, obrigar.

\section{XXII - Acontecimento: Reclusão}

Palavras-chave: “Ah, agora eu entendo: Ela sentia vergonha porque eu ainda me preocupava com Ela como um verdadeiro marido".

Objetivo do acontecimento: Mostrar os cuidados do marido dispensados a esposa na condição de isolamento e debilidade a que está reduzida.

Circunstância dada que gerou o acontecimento: O castigo imposto pela transgressão dela ao tentar matá-lo.

Objetivo do Agiota: Demonstrar e convencer a esposa de sua bondade e generosidade.

Obstáculos do Agiota: O silêncio, a indiferença e a ausência dela, o ressentimento dele.

Ações do Agiota: Espreitar, controlar, zelar, cuidar, doar, beneficiar, valorizar, afirmar, provar, demonstrar, cercar, insinuar, cortejar, obsequiar.

Objetivo da Dócil: Buscar, no isolamento, a reestruturação interna, a imersão em si mesma.

Obstáculos da Dócil: O interesse, o zelo e o controle do marido com relação a Ela, a culpa, a vergonha, o rubor.

Ações da Dócil: Assimilar, superar, dispensar, esconder, ignorar, vedar, afastar.

Objetivo da Lukéria: Inteirar-se do real estado de saúde da Dócil.

Obstáculos da Lukéria: O silêncio dele e o estado ensimesmado e débil da Dócil.

Ações da Lukéria: Zelar, cuidar, indagar, descobrir, obsequiar.

\section{XXIII - Acontecimento: Ressurreição}

Palavras-chave: “Estava caindo, estava caindo a venda dos meus olhos! Se começou a cantar na minha presença, então se esqueceu de mim!”.

Objetivo do acontecimento: Mostrar a virada radical de atitude do Oficial/Agiota gerada pela canção da esposa. 
Circunstância dada que gerou o acontecimento: A revelação expressa pela canção, recebida pelo Oficial/Agiota como um sinal de libertação e independência da Dócil, leva-o a descobrir e a dimensionar o amor que sente pela esposa.

Objetivo do Agiota: Admitir e dar evasão aos sentimentos que nutre pela esposa, os quais sempre escondeu até de si.

Obstáculos do Agiota: A desconfiança, a intuição, a alienação dela, o longo período de silêncio entre eles, a incomunicabilidade, o pressentimento de que Ela o tinha esquecido. O pressuposto consentimento existente entre eles: Ela permaneceria no seu canto e Ele no dele para sempre.

Ações do Agiota: Indagar, escutar, surpreender, espiar, irromper, fugir, aliviar, desafogar, abrandar, vibrar, desembaraçar, conjeturar, decidir, retomar.

Objetivo da Dócil: Superar a derrota, o esmagamento, a humilhação e o isolamento e ressurgir secretamente como ser livre.

Obstáculos da Dócil: O isolamento, a culpa, o estado físico e psíquico debilitado, o silêncio, a incomunicabilidade, o Oficial/Agiota.

Ações da Dócil: Esconder, libertar, cantar, comunicar, harmonizar.

Objetivo da Lukéria: Zelar pela saúde de sua senhora.

Obstáculos da Lukéria: A perplexidade dele, a falta de entendimento do que está acontecendo, o estado agitado dele.

Ações da Lukéria: Servir, ajudar, corresponder.

\section{XXIV - Acontecimento: Revelação}

Palavras-chave: “'Então tu ainda queres amor? Amor? E eu pensava que me deixarias assim'. Ah, essas foram as suas mais importantes palavras e as mais esclarecedoras para mim naquela noite, como se elas me dessem uma punhalada no coração!”.

Objetivo do acontecimento: Mostrar a precipitação do marido ao buscar recuperar o amor da mulher.

Circunstância dada que gerou o acontecimento: A consciência de seu amor por Ela e a possibilidade dela o ter esquecido.

Objetivo do Agiota: Reconquistar o amor da esposa.

Obstáculo do Agiota: O possível esquecimento, a rejeição, a independência, o afastamento, a indiferença dela, a condição de isolamento que Ele impôs a Ela. 
Ações do Agiota: Declarar-se, humilhar-se, expor-se, agradar, admirar, adorar, explicar-se, prometer, planejar, velar, cuidar, atordoar, importunar, socorrer.

Objetivo da Dócil: Evitar e rejeitar os arroubos do Oficial/Agiota.

Obstáculos da Dócil: O desespero, as súplicas e a humilhação dele, a piedade e generosidade dela, a saúde precária dela.

Ações da Dócil: Acalmar, apiedar-se, compreender, defender-se, esquivar-se, fugir, reagir, surpreender.

Objetivo da Lukéria: Zelar pela saúde da Dócil.

Obstáculo da Lukéria: O estado perturbado do patrão, o abalo psíquico e físico da Dócil.

Ações da Lukéria: Cuidar, acarinhar, ajudar.

\section{XXV - Acontecimento: Confissão}

Palavras-chave: “Amanhã Ela vai acordar, e eu vou lhe dizer tudo, e Ela vai compreender tudo”.

Objetivo do acontecimento: Mostrar o reconhecimento do herói sobre a verdade do seu passado e os motivos das atitudes para com a mulher.

Circunstância dada que gerou o acontecimento: O reconhecimento do herói da necessidade de contar toda a verdade sobre o seu passado na esperança de que Ela o compreenda e o perdoe.

Objetivo do Agiota: Comover a alma da esposa para receber o seu perdão e o seu amor.

Obstáculos do Agiota: A exposição, o próprio passado, o desmoronamento do ideal, a tentativa de assassinato, o ressentimento, a debilidade da mulher, o pavor, a reação dela e o distanciamento entre eles, o reconhecimento dos erros, o orgulho.

Ações do Agiota: Comover, declarar, revelar, reconhecer, esclarecer, prometer, desorientar, justificar, confessar, elogiar, exaltar, destacar, recordar, convencer.

Objetivo da Dócil: Ceder às súplicas e apelos do marido confessando sua culpa e reconhecendo ser uma assassina.

Obstáculos da Dócil: A impulsividade dele, a declaração dele, o amor dele, as súplicas dele, a fragilidade dele, o reconhecimento dele, a generosidade e a piedade dela, a bondade dela, a culpa dela.

Ações da Dócil: Acalmar, afastar, deter, recusar, fugir, pacificar, evitar, submeter-se, declarar-se, confessar. 


\section{XXVI - Acontecimento: Celebração}

Palavras-chave: “Eu a beijava como marido, pela primeira vez depois de uma longa separação”.

Objetivo do acontecimento: Mostrar a retomada do casamento, a celebração e a idealização do amor na esperança da felicidade almejada pelo Oficial/Agiota, acentuando o descompasso entre o entusiasmo dele e a petrificação e o pânico dela.

Circunstância dada que gerou o acontecimento: O reconhecimento e promessa de que será uma esposa fiel e que irá respeitá-lo.

Objetivo do Agiota: Festejar a realização do seu sonho de felicidade (provar para Ela o quanto ele a ama; comemorar a retomada do casamento; realizar o sonho de felicidade).

Obstáculos do Agiota: O pânico, a introspecção e a alienação dela.

Ações do Agiota: Adorar, idolatrar, exaltar, venerar, vibrar, festejar, comemorar, seduzir, possuir, admirar, declarar, afagar, transmitir, mostrar, constranger, impor, dominar, submeter, sujeitar.

Objetivo da Dócil: Expiar a culpa, se imolando e se oferecendo em sacrifício.

Obstáculo da Dócil: A falta de amor, a natureza liberta dela, arrebatamento dele, o amor dele, a indiferença dela em relação a Ele, a falta de intimidade, o desencanto eles se tornaram estranhos, alheios um ao outro.

Ações da Dócil: Compreender, decifrar e dimensionar o futuro, calar, aceitar, evitar, submeter-se, imolar, sacrificar, subordinar-se, redimir-se.

\section{XXVII - Acontecimento: Libertação}

\section{(Acontecimento Central)}

Palavras-chave: “Assustou-se com o meu amor, perguntou-se seriamente: aceitar ou não aceitar, e não suportando a questão achou melhor morrer”.

Objetivo do acontecimento: Mostrar o espírito liberto da Dócil, o seu resgate espiritual, optando pela morte voluntária com a imagem da Virgem com o Menino agarrada junto ao peito.

Circunstância dada que gerou o acontecimento: A tomada de consciência da incapacidade dela em corresponder aos apelos apaixonados do marido, e a impossibilidade de violar a sua natureza liberta e seus valores espirituais.

Objetivo da Dócil: Resgatar a sua liberdade, o seu maior bem espiritual. 
Obstáculos da Dócil: A vida, a juventude, a religiosidade.

Ações da Dócil: Protestar, rebelar, contemplar, refutar, afastar, ocultar, despedirse, pedir absolvição, pedir perdão, apelar, apaziguar, negar, desobedecer, precipitar-se.

Objetivo da Lukéria: Impedir que algum mal aconteça a sua patroa.

Obstáculo da Lukéria: O silêncio da Dócil, a discrição da Dócil, o mistério da Dócil, as atitudes e as ações estranhas da Dócil.

Ações da Lukéria: Vigiar, repreender, descobrir, compreender, indagar, estranhar, insistir, agradar, animar, intuir, surpreender, suplicar.

\section{XXVIII - Acontecimento: Súplica Cósmica}

\section{(Acontecimento Final ou Principal)}

Palavras-chave: “Cheguei atrasado! Só cinco minutos. O mais lastimável é que tudo não passou de um acaso. Isso é uma afronta! Por que a tenebrosa teimosia destruiu aquilo que me era mais caro que tudo?”.

Objetivo do acontecimento: Mostrar a atitude do herói diante da tragédia, o reconhecimento da sua condição de solidão e da destruição dos seus sonhos. A tomada de consciência da co-responsabilidade pelo suicídio da mulher.

Circunstância dada que gerou o acontecimento: O suicídio da Dócil.

Objetivo do Agiota: Decifrar a verdade sobre as causas da morte da esposa através de um mergulho em sua autoconsciência.

Obstáculo do Agiota: O orgulho, a vaidade, a exposição, o egoísmo, a mesquinhez, as falhas dele, a verdade, a consciência dele, o reconhecimento, admitir e aceitar a verdade, a honestidade.

Ações do Agiota: Lamentar, indagar, suplicar, confrontar, reclamar, contemplar, exaltar, recordar, exortar, negar, culpar, rebelar, amaldiçoar, desacatar, reconhecer, esbravejar, injuriar, afrontar, transgredir, atacar, encarar, admitir, despedir, aceitar e alienar.

Objetivo da Lukéria: Cumprir o seu dever até o último momento, prestando a última homenagem à sua senhora

Obstáculo da Lukéria: O Oficial/Agiota, a tragédia, a culpa.

Ações da Lukéria: Homenagear, velar, servir, enfeitar, preparar, rezar, enfrentar, culpar, refutar, despedir, contemplar. 


\section{DA AČ̃̃o AO ESPETÁCULO}

O sistema é antes de tudo prática artística. Esse é um trabalho prático sobre o papel; é a organização sobre os ensaios no trabalho prático artístico. É a sistematização envolvendo o processo de trabalho de toda a natureza artística do ator. ${ }^{264}$

Nessa parte final pretende-se relacionar, de forma sintética, a teoria sobre o “sistema”, desenvolvida nos capítulos I e II, e a investigação e análise apresentadas nos capítulos III e IV, com a realização da prática, com o ator, na montagem de A Dócil, de Dostoiévski, resgatando os elementos fundamentais do "sistema" que possibilitaram o processo de criação do espetáculo pelo diretor e ator por meio do método da análise ativa.

Para poder criar pelo método, há a exigência de um ator que seja capaz de improvisar todos os acontecimentos seqüenciais da obra e os tangenciais ao texto, que constituem o romance da vida das personagens, como também estar sempre presente de forma orgânica, em permanente estado de improvisação, no aqui e no agora, em cada apresentação do espetáculo, com adaptações renovadas.

A técnica da improvisação exige um grau elevado de disponibilidade, uma flexibilidade mental e física para a criação de partituras de ações físicas concretas e coerentes com a situação e com as circunstâncias da obra. O ator, para corresponder a essas exigências, deve passar por um nível elevado de formação e investigação sobre si mesmo. Necessita se submeter a uma formação corporal e mental continuada, que envolva todos os elementos necessários para a obtenção da ação orgânica. Esses elementos integram as investigações de K. Stanislávski que precederam o método das ações físicas, mas estão incorporados e articulados ativamente na criação através desse novo método, como podemos observar nas aulas-ensaios do mestre.

Considera-se que a capacidade para a improvisação deve ser inerente ao ator, pelo menos em embrião, e pode ser educada, desenvolvida e dominada através do treino constante da imaginação criativa, do desenvolvimento da intuição, do aperfeiçoamento das habilidades e da capacidade de criar em si mesmo o estado geral do improviso, que leva ao entusiasmo e ao jogo que contagia todo o coletivo.

Os atores, para poderem passar pelo processo de criação através do método da análise ativa, devem ter a formação adequada dentro do método das ações físicas, que

\footnotetext{
${ }^{264}$ KEDROV, M. N. Stat'i, retchi (Ensaios e discursos). Moscou: VTO, 1978, p.120.
} 
exige o conhecimento das leis objetivas da criação, ou seja, o domínio de seus elementos, para poderem gerar a ação orgânica. Essa vincula-se ao processo da relação conflituosa entre as personagens nas circunstâncias dadas e tem como meio de investigação a improvisação de études, sendo esse meio um dos fundamentos do método da criação, pois possibilita ao ator gerar a idéia da obra pela sua capacidade de existir nas circunstâncias dadas, experimentando a verdade organicamente e não por meio de especulações teóricas. Assim, o ator atua em seu próprio nome, com seu corpo físico e psíquico, e origina o texto do papel com suas próprias palavras.

Essa exigência determinou que os atores com os quais fosse trabalhar tivessem alguma familiaridade com o método, demanda correspondida pelos atores oriundos do Curso de Artes Cênicas da UFSM que haviam sido meus alunos e que se dispuseram a passar por um período de pesquisa e aperfeiçoamento com relação aos elementos do “sistema” na esfera psicofísica, considerados fundamentais.

Para dar uma idéia do processo de formação e experimentação a que os atores se submeteram, passo a descrever de forma bastante sucinta o trabalho prático sobre a natureza ativa dos elementos trabalhados através dos princípios que guiaram a sua condução:

Foi criado um treino físico básico, para o qual foram selecionados exercícios que, na sua execução, deveriam atender a alguns princípios fundamentais da organicidade desenvolvidos por meio dos elementos do "sistema". Assim deveriam propiciar o envolvimento de todo o corpo, por meio de um impulso físico, orgânico, que iniciaria nos pés, de onde a energia do movimento passaria a circular pelo corpo, pelas extremidades dos dedos das mãos e pelos olhos, atingindo, dessa forma, o espaço circundante. Os exercícios originaram-se de várias tendências corporais, que passaram por esse critério ativo. Esse treino dava início ao trabalho cotidiano produtivo e criativo, que tinha como objetivo, além do aquecimento, a aquisição das qualidades plásticas corporais expressivas, o controle, a prontidão, a precisão e oposição do movimento, e a emissão de raios, conforme os elementos do "sistema" relação, liberdade muscular e leis do movimento cênico. Esses princípios deveriam estar presentes em toda e qualquer ação psicofísica e tinham como objetivo fundamental despertar a atividade no ator, a sua organicidade, e obter a organização correta da "vida do corpo humano", fortalecendo dessa forma a "vida do espírito humano” da personagem a ser criada. 
O elemento tempo-ritmo foi desenvolvido, na prática, pelo treino das diferentes velocidades, criado por mim a partir desse elemento tão valorizado por $\mathrm{K}$. Stanislávski, sobre o qual já foi dissertado, e da teorização sobre os fundamentos do movimento cênico de I. É. Kokh. O ator, a partir do domínio de nove a onze velocidades, utilizadas nas mais variadas atividades, desde o mais básico dos deslocamentos no espaço, a caminhada, por exemplo, passa a incorporar diferentes dinâmicas e intensidades do movimento num determinado intervalo de tempo. Tanto na realização e encadeamento lógico e coerente da ação física, em sua linha ininterrupta, quanto na ação da palavra cênica e em todos os níveis da criação, é o tempo-ritmo que irá determinar a sua verdade cênica. Esse elemento, que K. Stanislávski considerou uma de suas maiores descobertas para a arte do diretor e, sobretudo, para a do ator, se constituiu num meio poderoso na criação da personagem, através de sua linha física e psíquica, na geração da ação da palavra pelo ator, e ainda na construção de acontecimentos pelo diretor e na encenação como um todo. Para o ator apreender sua total dimensão, interna e externa, é exigido não só o domínio mecânico da técnica, mas o envolvimento da própria essência, que abarca sua personalidade total, desde o instinto até o fluir corporal, mental e emocional, com observação e percepção apuradas e conectadas com as manifestações da vida que colocam todos os elementos do "sistema” em atividade. Sua correta aplicação na criação das ações físicas para a composição da partitura do papel e na articulação do texto constitui um instrumento para o ator, conferindo-lhe a capacidade de poder distribuir de forma correta o tempo-ritmo da linha transversal, de ação na condução do seu superobjetivo, e dando ao diretor a possibilidade de “orquestrar” o espetáculo.

A ação com objeto imaginário, aplicada na criação de études, foi a técnica usada para o ator desenvolver os elementos do “sistema' abordados nos capítulos I e II: a concentração, a percepção, a imaginação, o mágico “se”, as circunstâncias dadas, o superobjetivo, a linha transversal de ação, a relação, a adaptação, a fé e a verdade. A partir da observação pertinaz de situações cotidianas da vida do ator, foram construídas possibilidades narrativas que priorizassem o desenvolvimento dos círculos de atenção e da capacidade de transitar em suas diferentes esferas através da visualização de imagens concretas. A observação e percepção, como meio de alimentar a imaginação e desenvolver a sensibilidade, se deram sobre os mais variados fenômenos da vida e da natureza, que incluíram luz, cores, sons, ritmos, 
movimentos, linhas, atmosferas, energias, os quais passaram por um processo de síntese e foram expressos por meio de ações psicofísicas envolvendo o espectro corporal do ator em situações concretas, na composição de études. A individualidade do ator na criação, além da observação e percepção da realidade, na realização de études, concretizadas através de ações com objetos imaginários, com as quais o ator tivesse alguma familiaridade, foi estimulada por meio de inúmeros recursos oriundos das artes plásticas, música, canções, literatura e outras imagens. Essa prática tinha como objetivos trabalhar os elementos da ação para obter a organicidade e apreender a estrutura do pequeno núcleo da criação dramática, de seus momentos principais, já explicitados no capítulo I, que são o inicial, o fundamental, o central e o final.

O processo de investigação na criação, por meio da improvisação de études, capacitou o ator a dominar a evolução qualitativa da ação, através de seus momentos essenciais de mudanças e de valorizações de cada acontecimento, com as suas respectivas circunstâncias, objetivos, linha transversal de ação e idéia, e também possibilitou ao ator desenvolver a sua potencialidade criativa de forma orgânica, articulada e disciplinada. O domínio dos elementos estruturais do étude foi considerado imprescindível para o ator poder criar a partitura de ações lógica e coerente com o papel, conciliando, assim, a rigorosa subordinação ao superobjetivo da obra do autor com a liberdade criativa do ator, de expressão da sua individualidade, no entendimento da idéia.

Durante o período de experimentação que antecedeu à criação da montagem, procurou-se gerar no coletivo condições que favorecessem o surgimento da improvisação, pois penso ser esta um dos meios mais eficazes para manter sempre viva a verdade em cena, o que é essencial para a arte teatral. A permanência da atmosfera criativa por meio do improviso foi um dos grandes esforços realizados no período do trabalho do ator sobre si mesmo e durante o processo de criação de A Dócil, voltado, então, totalmente para a concretização do espetáculo.

O processo de escolha do texto obedeceu à evocação de algumas imagens já esmaecidas pelo tempo, mas que, de quando em vez, me perseguiam; lembranças longínquas de uma montagem de Krótkaia, de Dostoiévski, direção de Lev Dodin, encenada no teatro de câmera do BDT em Leningrado em 1981, com o grande ator Oleg Borissov (1929-1994) no papel do herói. A novela, que Dostoiévski chamou de fantástica pela forma, recebeu pela primeira vez, nos palcos soviéticos, leitura cênica, 
na qual o diretor conseguiu reunir a detalhada complexidade psicológica da obra com a linguagem artística do autor, concretizada no espetáculo ao longo de mais de três horas de duração.

O texto só foi lido quando já estava cursando as disciplinas do doutorado e fazia algumas tentativas de análise literária sobre a novela. A leitura da novela causou-me grande impacto pela sua dramaticidade e qualidades cênicas. A soma das impressões passadas, fortificadas, agora, pelo conhecimento do texto e pelas suas possibilidades dramáticas, aliadas ao número de personagens da obra, determinou minha escolha, pois vinha ao encontro do número de pessoas que participavam do laboratório sobre os elementos do "sistema" e o método de análise ativa.

A escolha dos atores para os papéis não foi determinada pelo critério de maior ou menor talento nem por um perfil adequado às personagens. O que contou foi a disponibilidade do grupo em participar de uma pesquisa que incluía uma montagem com caráter experimental. Sabia do desafio que ia ser enfrentado, pois se tratava de uma das obras curtas mais complexas de Dostoiévski, autor ainda não trabalhado por mim, ao longo de minha experiência acadêmica. A isso somavam-se outros fatores, como o elenco jovem, em que um dos atores teria que atuar no papel do herói, com o dobro de sua idade.

Além dessa dificuldade, de tornar verossímil a personagem, o ator, idealmente, teria de transitar pelos gêneros dramático e narrativo, este vivenciado tragicamente, o que exigiria a constante alteração de seu estado anímico. Na novela, o dramático se desenvolve por meio da narração do herói, o que exige um critério rigoroso de seleção dos acontecimentos por parte do diretor, para que os atores possam operar com esses dois níveis de forma diferenciada tecnicamente.

No tema dessa obra, ocupa lugar de destaque a falta de comunicação entre a protagonista e o antagonista, que se situam em posições radicalmente opostas. A relação entre ambos evidencia-se pelo ressentimento social, que tem raízes profundas na sociedade e na mentalidade cultural, mas também se fundamenta no egoísmo e na arrogância do caráter do antagonista, no apego insensato às coisas materiais, o que leva à destruição daquilo que é mais valioso na sua vida, ao extermínio de uma vida jovem, sua esposa, plena de possibilidades e sonhos.

Essa idéia toma universalidade no mundo contemporâneo, não somente manifesta nas relações humanas em nível pessoal, mas também em todas as relações predatórias do homem com seus semelhantes, com os demais seres e com a própria 
natureza. A idéia que permeia a concretização dramática do espetáculo é essa desumanização do homem, que termina destruindo as próprias possibilidades e potencialidades de ser e de vir a ser.

Foi a ação do ator, realizada nos acontecimentos do espetáculo eleitos na novela pelo diretor, pautada nos princípios do método de análise ativa, por meio da improvisação, que possibilitou a realização dessa complexa idéia, expressa pela relação conflituosa das personagens que a habitam. Procurei seguir os preceitos de Tovstonógov, que diz:

O êxito do trabalho depende da capacidade do diretor de completar três difíceis tarefas no processo de ensaios: construir os acontecimentos seqüenciais da obra, realizar o conflito em cada um dos seus episódios e manter todo o elenco de intérpretes em estado de prontidão para a improvisação. ${ }^{265}$

O processo criativo do espetáculo iniciou pela investigação do romance da vida das personagens, em que a improvisação aparece como um dos fundamentos do método de criação e foi aplicada, nessa etapa, para investigar, compreender e conhecer a abrangência das mesmas no seu plano universal. Toda a vida das personagens foi vivenciada na prática por meio de improvisações sobre os mais diversos temas, situações e circunstâncias que contemplassem essa totalidade.

Considero que esse procedimento de busca e descoberta, vivenciado no aqui e no agora, da vida pregressa das personagens e de projetar seus sonhos é uma forma ativa de concretizar a imaginação e a intuição do ator sobre a biografia das mesmas. Igualmente o ajudará, na atuação do papel em cena, a gerar a ação da palavra por meio das imagens referenciais ao texto, concretamente vivenciadas na experiência e na criação do papel como um todo. Pois este é limitado à parte, ou seja, ao médio círculo, ao particular, que constitui a história do autor, enquanto que a personagem pertence ao grande círculo, ao universal, possui uma amplitude maior e deve ser completada pela imaginação ativa do ator e do diretor.

Muitas imagens cênicas geradas nesse processo criativo, por meio da improvisação, de conhecimento da vida das personagens, fizeram parte do espetáculo, inseridas nos flashes de memória do herói. Essas reminiscências ajudavam a esclarecer o passado mais longínquo do herói, e justificavam, até certo ponto, o seu

${ }^{265}$ TOVSTONÓGOV, G. A. Zametki o teatral'noi improvizatsii (Apontamentos sobre a improvisação teatral). In. Revista TEATR, número 4, abril. Moscou: União dos escritores da URSS e Ministério da Cultura da URSS, 1985, p. 136. 
comportamento tão estranho e contraditório em relação à heroína, dando-lhe uma dimensão mais humana em seu estado trágico.

O trabalho de criação do espetáculo, realizado a partir dos fatos da obra, ocorreu concomitante ao da biografia das personagens, sendo que, sempre que necessário, foram criados études para desvendar a natureza de determinados conflitos. Todos os fatos referidos na narrativa e transformados em acontecimentos pela valorização do diretor foram concretizados por meio da ação psicofísica dos atores, colocados nas circunstâncias dadas na obra, de forma a estabelecer um processo ativo de luta entre os mesmos e o objetivo a ser alcançado no dado momento. Essa maneira do ator se colocar em nome próprio nas circunstâncias da obra, com tarefas ativas e concretas, para solucionar a proposição conflituosa do acontecimento através da ação psicofísica e gerar o texto com suas próprias palavras, é exigência da última metodologia de K. Stanislávski, que foi explicitada nos capítulos I e II e, de forma exemplar, em suas aulas-ensaios.

O estudo da análise da obra junto com o ator foi realizado não pela via intelectual, mas ativamente, no espaço cênico, pelo caminho da improvisação. Quando necessário, foram discutidos e explicitados os detalhes sobre a ação e as personagens, a linha da ação e do comportamento dos mesmos, a essência de suas inter-relações, revelados a linha ininterrupta da ação da obra, as circunstâncias, os objetivos de cada acontecimento. E assim foi determinado o conflito da ação, o superobjetivo e a linha transversal de ação, sempre ditados pela necessidade de esclarecimentos e aprofundamento das cenas. Para evitar a dispersão do objetivo do autor, o processo de criação, por meio da improvisação, foi conduzido de forma a subordinar 0 desenvolvimento da linha transversal de ação à lógica da novela, para poder construir dessa forma os acontecimentos seqüenciais da mesma.

Nos ensaios, com a pesquisa, buscou-se criar a atmosfera da ação de maneira ativa e orgânica, construindo, com os artistas, todas as possibilidades de reação orgânica nas mudanças geradas pela entrada de novas circunstâncias, encontrando o seu ritmo justo, para poder expressar sinceramente na cena a vida legitima, não qualquer condição emocional teatral, ou seja, a representação de sentimentos, tão abominada por K. Stanislávski.

O espetáculo foi construído pelo processo de improvisação na totalidade do tema dado pelo autor, sendo que a adaptação da novela e a sua composição, ou seja, a miseen-scène, foram resultados da ação, desse mergulho no tecido físico, mental e 
emocional do ator, para a criação, em cena, da imagem artística das personagens, de sua concretização pela linha física e, conseqüentemente, psíquica, nos acontecimentos seqüenciais da obra. Com o artista gerando as palavras a partir de si, de seu estado emocional em relação à imagem, expressando o exato sentido de sua compreensão da personagem, direto na cena, pelo processo ativo correspondente à obra do autor e à criação do espetáculo, obteve-se o resultado da adaptação da novela, o sistema do espetáculo.

Segundo as indicações de Tovstonógov ${ }^{266}$, as palavras escritas do texto são apenas uma parte do "todo invisível”, ainda não constituem a totalidade dramatúrgica da obra, pois, ao serem pronunciadas pelo ator em determinadas circunstâncias surgidas de situações concretas, elas geram vida. Faz-se necessário penetrar naquilo que está por trás das palavras; saber e poder, através da sua espessura, encontrar as circunstâncias dadas e, por meio delas, abrir caminho para os sentimentos e pensamentos do homem, os quais determinam nele essa ou aquela manifestação. A palavra é o resultado final do impulso, o qual surge de nossa relação com a vida, de nossa atitude e comportamento que exigem expressão. Esse processo começa a se realizar na alma do autor, para depois se repetir na alma do ator. Abre-se, assim, o caminho para o necessário salto qualitativo, de transformação e metamorfose do ator, ou seja, a passagem do atorpersonagem para a personagem-ator.

Nessa evolução, houve a necessidade, nos ensaios, de o ator encontrar as palavras justas, que se aproximassem cada vez mais das palavras do autor dentro das circunstâncias e acontecimentos concretos. Em cada ensaio, havia alguns acertos do diretor, junto com os atores, mudanças de palavras, de frases, monólogos, incluindo ou retirando do texto tudo aquilo que era necessário para explicitar a idéia do autor, conservando o seu estilo. Esse procedimento do diretor junto aos atores continuou sendo realizado, não só nas etapas de preparação da montagem, mas após o espetáculo ter estreado. $^{267} \mathrm{O}$ texto passou por inúmeras redações, feitas pelo diretor, e a montagem sofreu constantes articulações de suas partes, incluindo ou reduzindo textos, acontecimentos e imagens, sendo a versão final a que está agregada à tese.

\footnotetext{
${ }^{266}$ TOVSTONÓGOV, G. A. Zametki o teatral'noi improvizatsii (Apontamentos sobre a improvisação teatral). In. Revista TEATR, número 4, abril. Moscou: União dos escritores da URSS e Ministério da Cultura da URSS, 1985, p.138.

${ }^{267}$ O espetáculo A Dócil estreou em janeiro de 2005, no Teatro Dante Barone, em Porto Alegre. Realizou duas temporadas em teatros públicos entre outros, num total de 41 apresentações.
} 
Sabe-se que esse procedimento de compor a dramaturgia do espetáculo, quer pelo dramaturgo, quer pelo próprio diretor, por meio da pesquisa improvisacional, pela via orgânica dos atores, a partir de uma obra literária ou outro material textual, na história da encenação, não só a moderna, mas a clássica, conta com muitos exemplos.

Porém o que se salienta aqui não é o ineditismo de tal procedimento, mas aquilo que, sob meu ponto de vista, acredito ser a melhor maneira de realizar a encenação da prosa, ou seja, a concretização cênica de uma obra literária, através do processo dos ensaios por meio da improvisação, utilizando o método de análise ativa, que, por sua essência, propicia tal processo criativo e favorece a articulação das partes com o todo.

Seguem-se algumas considerações relativamente ao objetivo desse estudo sobre K. Stanislávski, o que penso ser essencial para desfazer os mal-entendidos existentes sobre o "sistema” como um todo. Mais especificamente, há insuficiente informação, em nosso país; existem poucas traduções diretas do russo sobre a metodologia e investigação dos últimos anos de sua vida, quando já não atuava nem assinava os espetáculos do TAM, mas trabalhava no Estúdio de Ópera Dramática. Como já foi dito, o local onde desenvolveu as suas últimas investigações práticas e a organização do “sistema”, que o levou à criação do método das ações físicas, foi, na maioria das vezes, a sua casa, em sua cadeira de enfermo.

Este trabalho pretende trazer uma contribuição aos profissionais da área teatral no sentido de ampliar e aprofundar a pesquisa sobre o método de análise ativa através de sua aplicação prática na abordagem da análise do texto dramático ou literário na criação do espetáculo. Esse método constitui-se num importante instrumento para os diretores, os atores e os pedagogos, bem como ajuda na compreensão da especificidade da arte teatral em sua totalidade e possibilita análise e leitura atualizadas do teatro contemporâneo. Em nossos dias, para todos os que trabalham com a arte teatral, independente de aplicarem outros métodos em suas criações, é imprescindível que conheçam as descobertas do grande e incomparável K. Stanislávski: ator, diretor, pesquisador e pedagogo.

São relevantes as criações teatrais não só do mestre e criador russo, mas também de seus discípulos, que confirmam o método como um princípio capaz de revelar a estrutura da ação, transcendendo a mera interpretação textual e possibilitando ao ator chegar ao âmago da ação que originou a palavra, o que lhe confere a função de criador. Para K. Stanislávski, possuir o domínio do método é ter um instrumento fundamental para especificidade da criação teatral, o qual, além de revelar a célula 
primeira da criação e articular a estrutura da ação entre a parte e o todo, possibilita aos criadores do espetáculo, diretor e ator, que produzam uma obra de arte original, sem alterar o sentido profundo do material textual que origina o espetáculo.

O fenomenal desenvolvimento dos estudos de K. Stanislávski, tanto na esfera teórica quanto na realização artística, na Rússia e na era soviética contribuiu para a realização deste estudo. O amplo material deixado pelo mestre abriu um enorme leque de possibilidades para a pesquisa teórica e prática. Neste trabalho foram abordados alguns dos princípios fundamentais do seu "sistema”, sobretudo, do método de análise ativa, que contém o das ações físicas, para a criação do diretor e do ator.

No que tange à palavra e à sua expressão, estamos longe do almejado pelo mestre. Seus ensinamentos e métodos, se forem desenvolvidos em sua totalidade, vão exigir muitos anos de estudo e dedicação prática para ser possível dominar essa complexa técnica, em que a palavra possa chegar a soar como música, como era o desejo do mestre. Não bastam algumas semanas de cursos, ou até alguns semestres de formação, ou a participação em algumas montagens. K. Stanislávski deixou material imenso e ímpar a ser explorado, subordinado aos princípios do "sistema”, que somente tangenciamos nesse estudo. Embora os avanços de Grotowski e do teatro antropológico, encabeçado por Barba, sejam muito significativos, penso que, salvo alguns grupos em nosso país, essas experiências ainda nos chegam como utopias.

Para seguir o método na criação do papel e do espetáculo, nos diz o mestre “saber é pouco", temos que "saber fazer": isso significa que são exigidos tempo, paixão e empenho permanentes. É necessário estar completamente comprometido com a investigação sobre si mesmo, com o aprimoramento técnico-artístico, e mais: para fazer parte do teatro de arte propagado pelo "sistema”, há a exigência constante de aperfeiçoamento humano, que para K. Stanislávski não se constituía em esfera separada mas, sim, complementar.

Pode-se dizer que a universalidade do "sistema” se depreende de seus princípios, que tratam da criação da arte teatral como um organismo vivo, em constante processo de produção pelo ator, como células vivas, orgânicas, articuladas pelo diretor. A metodologia de K. Stanislávski não perde o seu significado, mesmo diante de outra estética totalmente diferente, pois ela não determina estilos nem fórmulas, e quem dela se aproximar com essa concepção a destruirá. Se, por um lado, pode-se afirmar que o método de análise ativa é eficaz para a criação a partir de qualquer material textual e por meio dele é possível produzir um espetáculo bem articulado e criativo, por outro 
lado, deve-se advertir que os procedimentos podem ser repetidos, mas os processos são únicos e necessitam ser sempre construídos de novo. O caminho deve ser sempre aberto, não pela memória mecânica, mas pelo processo orgânico, como se fosse pela primeira vez. K. Stanislávski nos diz em suas lições:

Conseguir obter a verdade na cena é muito difícil. Em cada novo papel, o ator deve aprender novamente a andar, falar e saudar.[...] $\mathrm{Na}$ cena precisa voltar a estudar tudo novamente, abrir o caminho.[...] Para simplesmente sentar, na cena, estar no estado "eu existo", é necessário todo o sistema, é necessário o superobjetivo e a linha transversal de ação. ${ }^{268}$

O que permanece de cada nova criação é a experiência e, com ela, o aperfeiçoamento artístico e humano, o instrumento mais burilado e desenvolvido, a sensibilidade e a intuição mais afloradas, mas é necessário, toda vez, saber tocar o complexo instrumento de forma única, mas tocar, e não imitar, o que já foi feito. Para o ator poder fazer soar o seu próprio instrumento precisa ter um grande domínio de habilidades, possuir capacidade para fazer soar em uníssimo as três grandes vertentes, que são o corpo, a mente e os sentimentos. Tudo isso para saber tocar a música dos sentimentos, a "grande música”, o que exige descobrir novas nuanças jamais imaginadas, mergulhar em águas desconhecidas e encontrar o prazer da descoberta nessa imersão, trazendo à tona as recompensas e alegrias nos corações dos espectadores, pela revelação dos segredos encontrados e compartilhados durante essa viagem ao desconhecido. Essa é a grande arte, que K. Stanislávski almejava que soasse sempre de forma única, viva, potente, e que chegasse ao espectador e o arrebatasse por completo.

Para finalizar, cito novamente K. Stanislávski:

Todo o nosso sistema existe para que, com a técnica consciente, possa provocar a arte subconsciente e obrigue a nossa natureza a agir, mas a natureza - a melhor artista. Todos os elementos do sistema devem conduzir à criação da verdade interna do estado geral da arte. Nós aprendemos a procurar nas obras o superobjetivo e a conduzir a linha transversal de ação. Aquilo que agora nós estudamos - os assim chamados elementos do sistema - é a décima parte do sistema, isso é ainda o sistema com letras minúsculas. Para que se assimile, domine, os restantes nove décimos do sistema, o sistema com letras maiúsculas, é necessário aprender a conduzir à criação subconsciente. Tudo é para isso. O sistema com letras

268 STANISLÁVSKI, K. aput VINOGRADSKAIA, I. N. (org.) Stanislávski Repetíruet (Stanislávski ensaiando). Moscou: MKHT, 2000, p.444. 
minúsculas é prescindível sem o sistema com letras maiúsculas. Nos elementos existem iscas [manki]. Cada isca [manok] pode conduzir até a verossimilhança dos sentimentos e das paixões. A verossimilhança dos sentimentos - isto é, até o limiar do inconsciente, mas a autenticidade das paixões acontece após o limiar. ${ }^{269}$

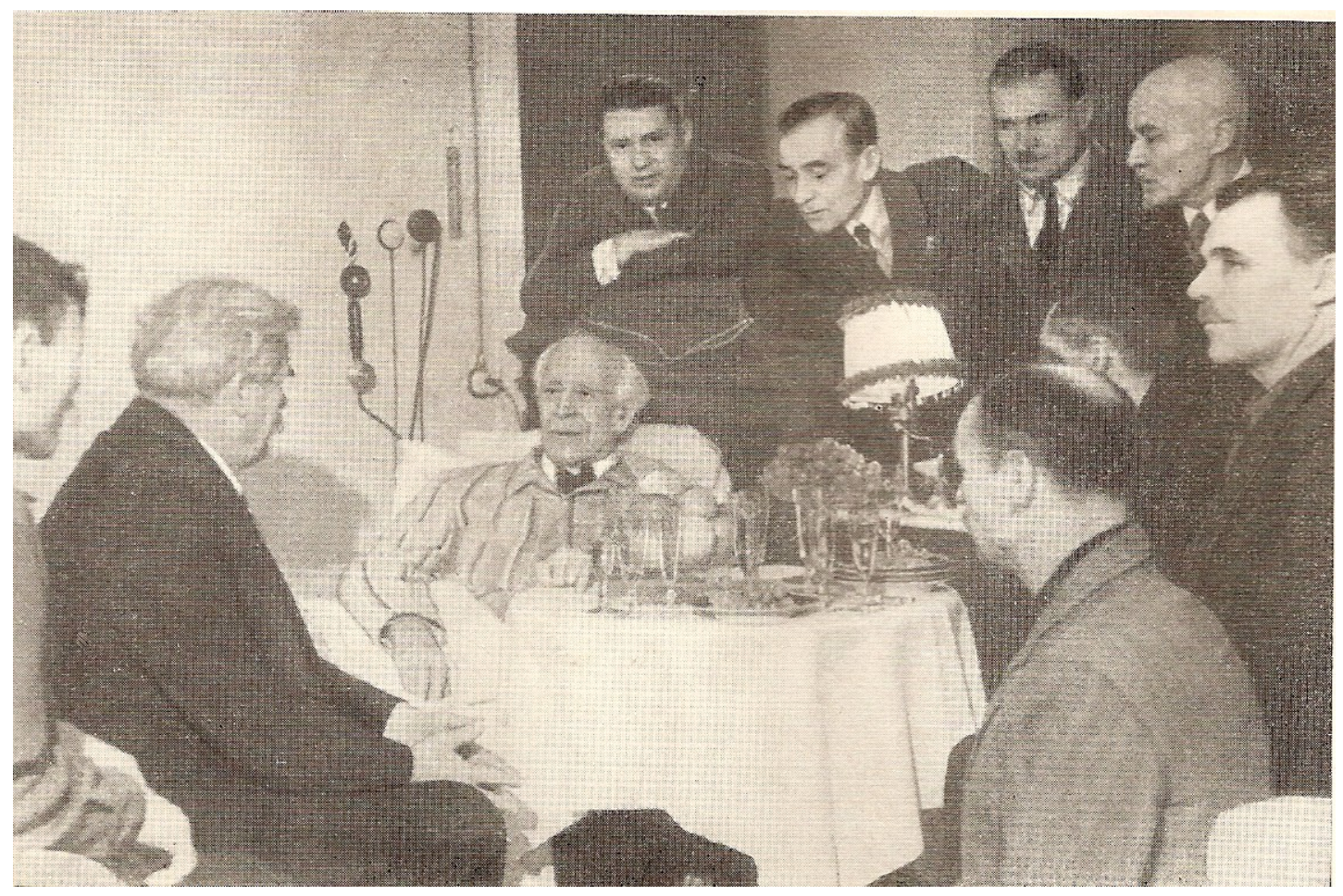

Konstantin Stanislávski no dia de seu aniversário de 75 anos com artistas e trabalhadores do TAM. 1938.

${ }^{269}$ STANISLÁVSKI, K. aput VINOGRADSKAIA, I. N. (org.) Stanislávski Repetíruet (Stanislávski ensaiando). Moscou: MKHT, 2000, p.443. 


\section{REFERÊNCIAS BIBLIOGRÁFICAS}

\section{De K. Stanislávski:}

STANISLÁVSKI, K. Sobránie sotchinéni v 8 tomakh, 1954-1961. Moiá jizn’ v iskússtve (Minha vida na arte). Tomo 1. Moscou: Iskusstvo, 1954.

. Sobránie sotchinénii v 8 tomakh, 1954-1961. Rabota aktiora nad soboi. Rabota nad soboi $v$ tvórtcheskom protsésse perejivânia (O trabalho do ator sobre si mesmo. O trabalho sobre si mesmo no processo da criação da vivência). Tomo 2, Moscou: Iskusstvo, 1954.

. Sobránie sotchinénii v 8 tomakh, 1954-1961. Rabota aktiora nad soboi. Rabota nad soboi $v$ tvórtcheskom protsésse voplochtchênia ( $\mathrm{O}$ trabalho do ator sobre si mesmo. O trabalho sobre si mesmo no processo da encarnação). Tomo 3, Moscou: Iskusstvo, 1955.

. Sobránie sotchinéni v 8 tomakh, 1954-1961. Rabota aktiora nad róliu (O trabalho do ator sobre o papel). Tomo 4, Moscou: Iskusstvo, 1957.

. Sobránie sotchinéni v 8 tomakh, 1954-1961. Stat'i, réchi, zamétki, dnevniki, vospominânia [1877-1917] (Artigos, Palestras, Anotações, Diário e Recordações [1877-1917]). Tomo 5, Moscou: Iskusstvo, 1958.

. Sobránie sotchinéni v 8 tomakh, 1954-1961. Stat'i, rechi, zamétki, dnevniki, vospominânia [1817-1938] (Artigos, Palestras, Anotações, Diário e Recordações [1917-1938]). Tomo 6, Moscou: Iskusstvo, 1959.

. Sobránie sotchinéni v 8 tomakh, 1954-1961. Pís'́ma 1886-1917 (Cartas 1886-

1917). Tomo 7, Moscou: Iskusstvo, 1960.

. Sobránie sotchinéni v 8 tomakh, 1954-1961. Pís'ma 1918-1938 (Cartas 1918-

1938). Tomo 8, Moscou: Iskusstvo, 1961.

. Pólnoie sobránie sotchiniéni $v$ vos'mi tomakh (As obras completas em oito volumes).

Moscou: Iskusstvo 1954-1 e 2 tom; 1955-3 tom; 1957-tom 4; 1958-tom 5; 1959-tom 6;

1960-tom 7; 1961 -tom 8.

. Moiá jisn' iskússtve (Minha vida na arte). Moscou: Iskusstvo, 1962.

. Vospominânia i pís’ma (Memória e cartas). Moscou: Ed. Progress, 1963.

. El trabajo del actor sobre su papel. Buenos Aires: Quetzal, 1977.

. El trabajo del actor sobre si mismo en el proceso criador de las vivencias. Buenos

Aires: Quetzal, 1980.

. Moiá jisn’ v iskússtve (Minha vida na arte). Moscou: Iskusstvo, 1983.

. El Trabajo del actor sobre si mismo en el proceso creador de la encarnación. Buenos

Aires: Quetzal, 1983.

. Mi vida en el Arte. Habana: Editorial Arte e Literatura, 1985.

. El Arte Escénico. México: Siglo Veintiuno Editores, 1985.

. Iz zapisnykh kníjek 1912-1938 (Dos cadernos de anotações 1912-1938). 2 v. Moscou:

VTO, 1986.

. Trabajos Teatrales: Correspondencia. Buenos Aires: Quetzal, 1986.

. Stanislávski repetíruiet (Stanislávski ensaiando). Moscou: Ed. MKHT, 2000.

. Lesione al Teatro Bol'soj. Roma: Dino Audino Editore, 2004. 


\section{Sobre K. Stanislávski e o "sistema":}

ABRAMIANA, D. N. (org.) Stanislávski v meniáiuschemsia mire (Stanislávski no mundo em transformação). Materiais do simpósio Internacional - de 27 de fevereiro a 09 de março de 1989. Moscou: MKTS, 1994.

BOLESLÁVSKI, R. A arte do Ator. São Paulo: Perspectiva, 1992.

CAVALIERE, A.; VASSINA, E. A herança de Stanislávski no teatro norte-americano: caminhos e descaminhos. In Crop. Theater Studies. Guest Editro Maria Silvia Betti. São Paulo: Humanitas/FFLCH/USP. Crop. Número 7, p. 1-394, 2001.

CRUCIANI, F. Registi Pedagoghi e Comunità Teatrale nel Novecento. Roma: E\&A editori associati, 1995.

CHUB, Iu. G. (org.) Tipítcheskie óbrazy na stsene. (Imagens cênicas típicas) Moscou: Iskusstvo, 1953.

DAL FORNO, A. “A organicidade do ator” - Dissertação de mestrado, Universidade Estadual de Campinas, Instituto de Artes, Campinas, 2002.

EFROS, A. Proféssia: regissior (A profissão do diretor). Moscou: Iskusstvo, 1979.

EINES, J. Alegato em favor del actor. Madrid: Editorial Fundamentos, 1985.

GIPPIUS, S. V. (org.) Stsenítcheskaia pedagôguika (Pedagogia cênica). Volume 2. Leningrado: LGITMiK, 1976.

GONTCHARÓV, A. A. Regissiôrskie tetrádi (Cadernos do diretor). Moscou: VTO, 1980.

GORCHAKOV, N. M. Las lecciones de 'regisseur' de Stanislávski. Montevidéu: Ediciones Pueblos Unidos, 1956.

. Vajtángov: lecciones de regisseur. $2^{\mathrm{a}}$ ed., Buenos Aires: Domingo Cortizo Editor, 1987.

GROTOWSKI, J. De la Compañia Teatral a el Arte como Veículo. El Performer. Respuesta a Stanislavski. In. Revista Máscara, Ano3, n¹1-12, México: Escenologia, 1993.

GUINSBURG, J. Stanislávski, Meyerhold e Cia. São Paulo: Perspectiva, 2001. . Stanislávski e o Teatro de Arte de Moscou, 2ª Ed. São Paulo: Perspectiva, 2001.

JIMENEZ, S. (org.) El Evanagelio de Stanislávski segun sus apostoles, los apócrifos, la reforma, los falsos profetas y Judas Iscariote. México: Gaceta, 1990.

KALÁCHNIKOV, I. C. Estetítcheski ideal K. Stanislávskovo (O ideal estético de K. Stanislávski). Moscou: Naúka, 1965.

KEDROV, M. N. Stat’i, retchi (Ensaios e discursos). Moscou: VTO, 1978. 
KISSELIOVA, N. V.; FROLÓV, V. A. Osnóvi sistémy Stanislávskovo (Fundamentos do Sistema de Stanislávski). Moscou: Fenix, 2000.

KLIMOVA, L. P. Soderjatel'nost' stsenitcheskoi formy (A riqueza do conteúdo das formas cênicas). Leningrado: LGITMiK 1977.

. (org.) Problémy teórii i práktiki rússkoi sovétskoi regissúry - 19l7-1925. Sbornik statéi. (Problemas teóricos e práticos da direção russo soviética - 1917-1925. Coletânea de artigos). Leningrado: LGITMiK, 1978.

KNÉBEL, M. O. O tom, tchto mne kájetsia osóbenno vájnym (Sobre o que me parece especialmente importante). Moscou: Iskusstvo, 1971.

. Poésia pedagóguiki (Poesia da pedagogia). Moscou: VTO, 1976.

. O déistvennom análise piécy i roli (Sobre a análise ativa da peça e do papel). Moscou: Iskusstvo, 1982.

.Poética de la Pedagogía Teatral. México: Siglo Veintiuno Editores S.A, 1991.

. El Último Stanislavski, Análisis Activo de la Obra y el Papel. Madrid: Editorial Fundamentos, 1999.

.La Palabra en la Creación Actoral. Madrid: Editorial Fundamentos, 2000.

KOKH, I. É. Osnóvy stsetchískogo dvijênia (Fundamentos do movimento cênico). Leningrado: Iskusstvo, 1970.

- Osnóvy stsenítcheskogo dvijênia (Fundamentos do movimento cênico). Moscou: Prosvechtchenie, 1976.

KOKÓRIN, A. K. Vam priviet ot Stanislávskovo (Saudações de Stanislávski para vocês). Moscou: A.K. Kokórin, 2001.

KOZLIANINOVA, I. P. (org.) Kul'tura stsenicheskoi rechi (A cultura da palavra cênica). Moscou: VTO, 1979.

KRÍSTI, G. Vospitânie aktiora chkóly Stanislávskovo (Formação de ator da Escola de Stanislávski). Moscou: Iskusstvo, 1978.

KUSNET, E. Introdução ao “Método da Ação Inconsciente”. São Paulo: FAAP, 1971. . Ator e Método. São Paulo: Hucitec; Rio de Janeiro: Funarte, 2003.

LEBEDEVA, V. E. Liúdi i súd'by. Xx vek (Pessoas e destinos. Século XX). Moscou: O.G.I., 2002.

LITVIN, B. Masterstvo regissiora: poisk obraznosti (Maestria do diretor: busca da expressividade). Perm': IPP Real, 2000.

LIVNEV, D. G. Stsenítcheskoe perevoploschênie (Metamorfose cênica). Moscou: GITI, 1991.

MARINIS, M. de. In Cerca dell'attore: um balancio del Novecento teatrale. Roma: Bulzoni Editore, 2000.

MEYERHOLD, V. E. Stat'i, pís'ma, rétchi, besêdy (Artigos, cartas, discursos, palestras). 2 v. Moscou: Iskusstvo, 1968. 
Comunicacion - Textos Teóricos. Vol. 01 e 02. Madrid: Comunicación, 1972.

. Tvórtcheskoe naslédie (A herança artística de V. E. Meyerhold). Moscou: VTO, 1978.

MOLLICA, F. (org). Il teatro possibile: Stanislavskij e il Primo studio Del Teatro d'arte di Mosca. Firenze: La Casa Usher, 1989.

NEMERÓVSKI, A. Plastítcheskaia vyrazítel'nost' aktiora (A expressividade plástica do ator). Moscou: Iskusstvo, 1976.

NEMIRÓVITCH-DÂNTCHENKO, V. I. O tvórtchestve aktiora (Sobre o trabalho criativo do ator). Moscou: Iskusstvo, 1973. . Retsénzii, ótcherki, 1917-1942 (Resenhas e crônicas, 1917-1942). Moscou: VTO, 1980.

POLAMÍCHEV, A. Masterstvó regissióra: déistvenni análiz piêcy (A maestria do diretor: a análise da ação da peça). Moscou: Prosveschênie, 1982.

. Masterstvó regissióra: ot análisa k voploschéniu (A profissão do diretor: da análise à concretização cênica). Moscou: Iskusstvo, 1992.

POLIAKOVA, E. A. Poétika drámy i estétika teatra v románe (A poética do drama e a estética do teatro no romance). Moscou: RGGU, 2002.

POPOV, A. D. Tvórtcheskoe nasliédie. Vospominánia i razmychliênia o teatre (A herança artística. Memórias e reflexões sobre teatro). Moscou: VTO, 1979.

.Tvórtcheskoe nasliédie. Stat'i, doklády, vystupiênia (A herança artística. Artigos. Comunicações, Discursos). Moscou: VTO, 1980.

RIPELLINO, A. M. O Truque e a Alma. São Paulo: Perspectiva, 1996.

REMEZ, O. Ia. (org.) Mastertsvo regissiora - pérvi kurs - Sbórnik naútchnykh trudov.

(Maestria do diretor - primeiro curso). Moscou: GITIS, 1982.

REVISTA MÁSCARA. Stanislávski, Esse Desconocido. Ano 3, número 15. México, D.F.: 1993.

RUFFINI, F. Teatro e Boxe: I'atleta del cuore nella scena del Novacento. Bologna: Società Editrice il Mulino, 1994.

. Teatri sopra la pelle teatro sotto la pelle. La Rivista del Manifesto, Itália, número 9, 2000. Disponível em www.larivistadelmanifesto.it/archivio/9/9A2000915.html, data de acesso 26/09/2001.

. Stanislavskij: Dal lavoro dell'attore al lavoro su di sé. Roma: Laterza, 2003.

RUGGIERI, V. L'Esperienza Estéticaa - Fondamenti psicofisiologici per un 'educazione estética. Roma: Ed.Armando, 1997.

SCANDOLARA, C. "Os estúdios do Teatro de Arte de Moscou e a formação pedagógica teatral no século $X X$ ” - Dissertação de mestrado, Universidade Estadual de Campinas, Instituto de Artes, Campinas, 2006. 
SERRANO, R. Tesis sobre Stanislavski: en la educación del actor. México: Escenología, 1996.

SLÓNOVA, N. Jisn’ na stsene (A vida na cena). Moscou: Iskusstvo, 1971.

STRÓEVA, M. N. Regissiórskie iskânia Stanilávskovo - 1898-1917 (As buscas do Stanislávski encenador - 1898-1917). Moscou: Naúka, 1973.

- Regissiórskie iskânia Stanilávskovo - 1917-1938 (As buscas do Stanislávski encenador - 1917-1938). Moscou: Naúka, 1977.

STRÓMOV, Iu. A. Put' aktiora k tvórtcheskomu perevoploschéniu (O caminho do ator para a metamorfose artística). Moscou: Prosveschênie, 1980.

SULÍMOV, M. V. Natchálni etap rabóty regissiora nad piésoi (Etapa inicial do trabalho do diretor sobre a peça). Leningrado: LGITMiK, 1979.

. Regissior naediné s piéssoi, 1999 (O diretor em solidão com a peça). Mundo virtual www.domika dramaturga. 03/2002.

SZABO, D. Traité de mise em scène. Méthode dês actions scéniques paradoxales. Paris: L’Hartmattan, 2001.

TAKEDA, C. L. O cotidiano de uma lenda: Cartas do Teatro de Arte de Moscou. São Paulo: Perspectiva, 2003.

TCHEKHOV, M. Para o ator. São Paulo: Martins Fontes, 1986.

. Literatúrnoe naslêdie $v$ dvukh tomakh (Pesquisa na literatura em dois tomos). Sob a redação científica de Maria O. Knébel. Moscou: Iskusstvo, 1986.

TOPORKÓV, V. O. Stanislavski na repetítsii (Stanislávski nos ensaios). Moscou: Iskusstvo, 1950. . Stanislavsky dirige. Buenos Aires: Compañía General Fabril Editora, 1961. . Stanislavskij alle prove: gli ultimi anni. A cura di Fausto Malcovatti. Milano: Ubulibri, 1991.

TOVSTÓNOGÓV, G. A. Krug Mýslei (Círculo dos pensamentos). Leningrado: Iskusstvo, 1972. . Zérkalo Stséni (O espelho da cena). 2 volumes. Leningrado: Iskusstvo, 1980. . La profesion de diretor de escena. La Habana: Ed.Arte y Literatura, 1980. . Zametki o teatral'noi improvizatsii (Apontamentos sobre a improvisação teatral). In. Revista TEATR, número 4, abril. Moscou: União dos escritores da URSS e Ministério da Cultura da URSS, 1985. . Premiéry (Estréias). Moscou: Artist. Regissior.Teatr, 1994.

TSIMBAL, S. Tvórtcheskaia sud’ba Pevtsova (O destino artístico de Pevtsov). Moscou/Leningrado: Iskusstvo, 1957.

VAJTÁNGOV, E. Lecciones de Regisseur. Buenos Aires: Editorial Quetzal, 1987. . E. Vajtángov: Teoria y práctica teatral. Jorge Suara (org). Madrid: Realizacion Gráfica: Carácter S.A., 1997. 
VARPAKHÓVSKI, L. Nabliudiénia, análiz, ópyt (Anotações, análise, experiência). Moscou: VTO, 1978.

VINOGRÁDSKAIA, I. N. (org.) Jisn' i tvórtchestvo Stanislávskovo (A vida e a arte de Stanislávski). Moscou: VTO, 1 e 2 tomo - 1971; 3 tomo - 1973; 4 tomo - 1976. (org.) Stanislávski Repetíruet (Stanislávski ensaiando). Moscou: MKHT, 2000.

. (org.) Jisn' i tvórtchestvo Stanislávskovo - Letopis', tom 4 -1928-1938 (A vida e a arte de Stanislávski - Anais tomo 4 - 1928-1938). Moscou: Moskóvski Khudójestvenni Teatr, 2003.

VLADÍMIROV, S.V. Redaktsiónnaia kolléguia. U istókov regissury (Nas origens da direção teatral). Leningrado: LGITMiK, 1976.

VLADÍMIROVA, Z. M. O. Knébel. Moscou: Iskusstvo, 1991.

ZABOZLAEVA, T.B. (org.) Iz istórii rússkoi sovétskoi regissúry - 1930-kh godov (Da história da arte de direção russa). Leningrado: LGITMiK, 1979.

ZAKHAVA,V. Masterstvó aktiora i regissiora (A profissão do ator e do diretor) Moscou: Prosveschênie, 1978.

ZINGERMAN, B.I. Tchelovek $v$ meniáiuchtchemsia mire. Zamétki na temu teatra XX veka (O homem no mundo em transformação. Anotações no tema do teatro do século XX). In: Teatr XX Veka - zakonomérnosti razvítia (O teatro do século XX - as leis do desenvolvimento). Moscou: Indrik, 2003.

. Bestsennye uroki Stanislavskovo (As valiosas aulas de Stanislávski). In: Teatr XX

Veka - zakonomernosti razvítia (O teatro do século XX - as leis do desenvolvimento). Moscou: Indrik, 2003.

. Sviazúiustchaia nit' pissáteley i regissiórov (O fio de ligação entre autores e diretores). Moscou: OGI, 2002.

ZVEREVOI, N.A. (org.) Mastertsvó regissióra i-v kúrsy (Maestria do ator - cursos de I-V). Moscou: GITIS, 2002.

\section{De F. M. Dostoiévski:}

DOSTOIÉVSKI, F. M. Os Irmãos Karamazov. São Paulo: Abril Cultural, 1971. . Pobre Gente / O Duplo. Rio de Janeiro: Companhia José Aguilar Editora, 1975. . Krótkaia (A Dócil). Obras Completas, Tomo 10. Leningrado: Naúka, 1982. . Dnevnik pissátelia (O diário do escritor). São Petersburgo: Ázbuka, 1999. . O Crocodilo e Notas de Inverno sobre Impressões de Verão. Tradução de Boris Schnaiderman. São Paulo: Ed.34, 2000. . Memórias do Subsolo. Tradução de Boris Schnaiderman. São Paulo: Ed.34, 2000. . Crime e Castigo. Tradução de Paulo Bezerra. São Paulo: Ed.34, 2001. . O Idiota. Tradução de Paulo Bezerra. São Paulo: Ed.34, 2002.

2002 Niétotchka Niezvânova. Tradução de Boris Schnaiderman. São Paulo: Ed.34, . O Eterno Marido. Tradução de Boris Schnaiderman. São Paulo: Ed.34, 2003. 
Duas Narrativas Fantásticas - A Dócil e O Sonho de um Homem Ridículo.

Tradução de Vadim Nikitin. São Paulo: Ed.34, 2003.

. Uma Criatura Dócil. Tradução de Fátima Bianchi. São Paulo: Cosac\&Naif, 2003.

. Um Jogador. Tradução de Boris Schnaiderman. São Paulo: Ed.34, 2004.

. “Bobók”. Tradução de Paulo Bezerra. São Paulo: Ed.34, 2005.

Os Demônios. Tradução de Paulo Bezerra. São Paulo: Ed.34, 2005.

\section{Sobre F. M. Dostoiévski:}

ACHIMBÁIEVA, N. T. Sérdtse $v$ proizvedéniakh Dostoiévskovo i bibléiskaia antropológia (O coração na obra de Dostoiévski e antropologia bíblica). In. Dostoiévskii v kontsé XX véka (Dostoiévski no final do século XX). Moscou: Klassika Plius, 1996.

ALEKSÉIEV, M. O dramatícheskikh ópytakh Dostoiévskovo (Sobre as experiências dramáticas de Dostoiévski). In: Tvórtchestvo Dostoiévskovo (A obra de Dostoiévski 1821-1881-1921). Odessa: , 1921.

ARBAN, D. Dostoiévski. Rio de Janeiro: José Olympio, 1989.

BAKHTIN, M. Problemas da Poética de Dostoiévski. $3^{\mathrm{a}}$.ed, Rio de Janeiro: Forense Universitária, 2002.

BARBOSA, J. A. Dostoiévski sob o manto do profeta. Dossiê Cult. São Paulo, 2002.

BERDIÁEV, N. Mirosozertsánie Dostoiévskovo (O mundo contemplativo de Dostoiévski). Moscou: I. Zakharov, 2001.

BIANCHI, M de F. Os Caminhos da Razão e as Tramas Secretas do Coração: a representação da realidade em A dócil, de Dostoiévski, dissertação de mestrado FFLCH-LE: USP: São Paulo, 2001.

BORISOV, O. Bez znákov prepinánia - dnevnik 1974-1994 (Sem sinais de pontuação diário 1974-1994). Moscou: Ast.Astrel', 2002.

DOstOIÉVSKI, A. G. Meu Marido Dostoiévski. Tradução de Zóia R. Prestes. Rio de Janeiro: Mauad, 1999.

FOKIN, P. E. K voprósu o génezise “Dnevnika Pisatelia” 1876-1877 gg. F. M. Dostoiveskovo (Perguntas sobre a gênese do "Diário do Escritor” 1876-1877 de F. M. Dostoiévski). In. Dostoiévskii v kontsé XX veka (Dostoiévski no final do século XX). Moscou: Klassika Plius, 1996.

FRANK, J. Pelo Prisma Russo: Ensaios sobre Literatura e Cultura, São Paulo: Edusp, 1992.

. Dostoiévski: As sementes da revolta, 1821-1849. São Paulo: Edusp, 1999.

Dostoiévski: Os anos de provação, 1850-1859. São Paulo: Edusp, 1999.

Dostoiévski: Os efeitos da libertação, 1860-1865. São Paulo: Edusp, 2002.

. Dostoiévski: Os anos milagrosos, 1865-1871. São Paulo: Edusp, 2003. 
GROSSMAN, L. Dostoiévski Artista, Rio de Janeiro: Civilização Brasileira, 1967.

GURG, M. Transformátsia motívov 'Krótkoi' v póvesti F. Moriaka 'Tereza Dekeiru' (A transformação do motivo 'Krótkaia' na obra 'Thérèse Desqueyroux' de F. Mauriac) In. Dostoevskii i mirovaia kul'tura - Al'manakh n.13 (Dostoiévski e a cultura mundial Almanaque n.13). São Petersburgo: Serébriani Vek, 1999.

KULECHOVA, V. I. (org.) Rússkaia literatúra XIX veka i khristiânstvo (Literatura do século XIX e cristianismo). Moscou: Moskóvskogo Universiteta, 1997.

LOTMAN, Iu. M. A Estrutura do Texto Artístico. Lisboa: Estampa, 1978.

; USPENSKII, B.; IVANÓV, V.; e outros. Ensaios de semiótica soviética. Lisboa: Livros Horizonte, 1981.

Óbrazy priródnykh stikhíy v rússkoi literatúre [Púchkin-Dostoiévski-Blok] (As imagens dos elementos da natureza na literatura russa [Puchkin-Dostoiévski-Blok]). In. LOTMAN, Iu. M. Puchkin - biográfia pissátelia (Puchkin - biografia do escritor). São Petersburgo: Iskusstvo, 1995.

. Iazyk teatra (A linguagem do teatro). In: LOTMAN, Iu. M. (Lotman sobre a arte). São Petersburgo: Iskusstvo, 1998.

MELETÍNSKI, E. M. A poética do mito. Rio de Janeiro: Florense Universitária, 1987. . Os Arquétipos Literários. São Paulo: Ateliê Editora, 1998.

MIKHNOVETS, N. Mekhanízm smysloporojdênia v 'Krótkoi' (O mecanismo originário da idéia de 'Krotkaia'). In. Dostoêvski i mirováia kul'tura - Al'manakh n.13 (Dostoiévski e a cultura mundial - Almanaque n.13). São Petersburgo: Serebriani Vek, 1999.

NINOVA, A. A. (org.) Dostoiévskii i teatr - Sbórnik statéi (Dostoiévski e teatro - coletânea dos ensaios). Leningrado: Iskusstvo, 1983.

PONDÉ, L. F. Crítica e profecia: a filosofia da religião em Dostoiévski. São Paulo: Ed. 34, 2003.

SANTA ROSA, V. Dostoiévski, um cristão torturado. Brasília: Civilização Brasileira, 1980.

SCHNAIDERMAN, B. Dostoiévski: Prosa Poesia. São Paulo: Perspectiva, 1982.

STEPANIAN, K. (org.) Dostoiévski v kontse xx veka (Dostoiévski no fim do século XX). Moscou: Klassika Plius, 1996.

VASSINA, E.; D’AGOSTINI, N. Dostoiévski: Literatura e Teatro. Anais do colóquio nacional letras em diálogo e em contexto: rumos e desafios. Porto Alegre: Programa de Pós-graduação em Letras da UFRGS, 2003. 


\section{Bibliografia Geral:}

APPIA, A. Attore Musica e Scena. Milão: Feltrinelli Editore, 1983.

ARISTÓTELES, F. Poética. Tradução de Eudoro de Sousa. Lisboa: Casa da Moeda, 1986.

- Arte Retórica e Arte Poética. Tradução de Antônio Pinto de Carvalho. Rio de Janeiro: Tecnoprint, s/d.

ARMELLA, V. A. El concepto de técnica, arte y producción en la filosofia de Aristóteles. México D.F.: Fondo de Cultura Económica, 1993.

ARTAUD, A. Artaud e o teatro. São Paulo: Perspectiva, 1990. . Linguagem e Vida. São Paulo: Perspectiva, 1995. . O Teatro e seu Duplo. 2a ed., São Paulo: Martins Fontes,1999.

ASLAN, O. O ator no século XX. São Paulo: Perspectiva, 2003.

AUERBACH, E. Mímesis. 2a .ed., São Paulo: Perspectiva, Coleção Estudos, 1987.

BAKHTIN, M. Questões de literatura e de Estética: A Teoria do Romance. 2a .ed., São Paulo: UNESP/Hucitec, 1990.

. Estética da criação verbal. São Paulo: Martins Fontes, 1997.

BARBA, E. Além das Ilhas Flutuantes. São Paulo - Campinas: Hucitec e Ed. da Unicamp, 1991.

. A Canoa de Papel: Tratado de Antropologia Teatral. São Paulo: Hucitec, 1994.

; SAVARESE, N. A Arte Secreta do Ator: Dicionário de Antropologia Teatral.

Campinas: Ed. da Unicamp, 1995.

BENDER, I. C. Comédia e riso: uma poética do teatro cômico. Porto Alegre: Ed. Universidade/UFRGS/EDPUCRS, 1996.

BENTLEY, E. O dramaturgo como pensador: um estudo da dramaturgia nos tempos modernos: Wagner, Ibsen, Strindberg, Shaw, Pirandello, Sartre, Brecht. Rio de Janeiro: Civilização Brasileira, 1991.

BERDiÁEV, N. A Idéia Russa - Problemas Básicos do Pensamento Russo do Século $X I X$ e do Início do Século XX. Tradução de José Mata Veríssimo e Elena Vássina. In. Revista de Estudos Orientais, n.4. São Paulo: USP/FFLCH, 2003.

BERGSON, H. Matéria e Memória. Ensaio sobre a relação do corpo com o espírito. São Paulo: Martins Fontes, 1999.

BERTHOLD, M. História Mundial do Teatro. São Paulo: Perspectiva, 2001.

BORNHEIM, G. Brecht - A Estética do Teatro. São Paulo: Graal, 1992.

BORDINI, M. G. Fenomenologia e teoria literária. Criação \& Crítica, volume 3. São Paulo: Edusp, 1990. 
BOUFFONNEERIES. Exercice (S). Lectoure: Bouffonneirries-Contrastes, Revue Trimestrielle. 18-19, 1989.

. Exercice (S) 2. Lectoure: Bouffonneirries-Contrastes, Revue Trimestrielle. 24-25, 1991.

BROOK, P. El Espacio Vacío, arte e técnica del teatro. Barcelona: Nexos, 1986.

. O Ponto de Mudança, Quarenta anos de experiências teatrais: 1946-1987. 2a ed., Rio de Janeiro: Civilização Brasileira, 1995. . A Porta Aberta. Rio de Janeiro: Civilização Brasileira, 1999.

BROWN, R. M. El Arte del suicidio. Madrid: Editorial Síntesis, 2001.

CAMPBELL, J. O Herói de mil faces. São Paulo: Cultrix/Pensamento, 1997.

CARLSON, M. Teorias do Teatro: Estudo histórico-crítico, dos gregos à atualidade. Tradução de Gilson César Cardoso de Souza. São Paulo: Ed. da Unesp, 1995.

CAVALIERE, A. O Inspetor Geral de Gogol/Meyerhold. São Paulo: Perspectiva, 1996. ; VASSINA, E.; SILVA, N. (org.). Tipologia do simbolismo nas culturas russa e ocidental. São Paulo: Associação Editorial Humanitas, 2005.

CRAIG, E. G. Del arte del teatro. Buenos Aires: Libreria Hachette, s/d.

CRUCIANI, F. Il “luogo dei possibili”. In: GUCCINI, Gerardo; VALENTI, Cristina (org.). Tecniche delle rappresentazione e storiografia: materili della sesta sessione dell'ISTA (p.46/53). Milão: Biblioteca Universale Synergon, 1992.

COPEAU, J. Il luogo del teatro. Antologia degli scriti a cura di Maria Inês Aliverti. Firenze: La Casa Usher, 1988.

DODDS, E. R. Os gregos e o irracional. São Paulo: Escuta, 2002.

DAMÁSIO, A. O Erro de Descartes Emoção, Razão e Cérebro Humano. São Paulo: Companhia das Letras, 1998.

- O Mistério da Consciência. Do corpo e das Emoções ao conhecimento de si. São Paulo: Companhia das Letras, 2000.

DIETERICH, G. Diccionario del Teatro. Madrid: Alianza Editorial, 1995.

DREIDEN, S. D.; PEVTSOVA, P. I. (org.). I. N. Pevtsov - Literatúrno-teatrálnoe naslêdie (I. N. Pevtsov - A herança literária e teatral). Moscou: VTO, 1978.

EISENSTEIN, S. A Forma do Filme. Rio de Janeiro: Jorge Zahar, 2002. . O Sentido do Filme. Rio de Janeiro: Jorge Zahar, 2002.

FELDENKRAIS, M. Consciência pelo Movimento, 5ª . Ed. São Paulo: Summus, s.d.

GÖETHE, J. W. Fausto. La Habana: Editorial Arte y Literatura, 1980. 
GROTOWSKI, J. Em Busca de Um Teatro Pobre. Rio de Janeiro: Civilização Brasileira, 1976.

GROTOWSKI, J. Tecniche Originarie Dell'Atore. Italia: Istituto Del Teatro e dello Spettacolo: I cattedra di Storia del teatro e dello spettacolo. Transcrição integral das lições de Jerzy Grotowski feita por: Francesca Catarci, Maria Rosaria Iaruzzi, Donatella Massimilla, Giulio Cesare Scervini,MariaBruna Sirabella e Luiza Tinti.Tradução de Luisa Tinti, digitado, s/ed, 1982. . Hacia um teatro pobre. México D.F.: Siglo Veintiuno, 1986.

. El Performer. In. Revista Máscara, Ano 3, números 11-12, México: Escenologia, 1993.

. El Príncipe Constante de Ryszard Cieslak. In. Revista Máscara, número 16, México: Escenologia, 1994.

GUINSBURG, J.; NETO, T. C.; CARDOSO, R. C. Semiologia do Teatro. São Paulo: Perspectiva , 1988.

GURDJIEFF, G. I. Encontros com Homens Notáveis. São Paulo: Pensamento, 1999. . Gurdjieff fala a seus alunos. 9a. Ed. São Paulo: Pensamento, 2000.

HAOULI, J. El. Demetrio Stratos: em busca da voz-música. Londrina: J.E. Haouli, 2002.

HAUSER, A. Introduccion a la Historia del Arte. La Habana: Arte y Sociedad, 1969. . História Social da Literatura e da Arte. Tradução de Walter H. Geenen. $2^{\text {a }}$ ed. v.1 e v.2. São Paulo: Mestre Jou, 1972.

HEGEL, F. De lo Bello y sus Formasi Tradução de Manuel Granell. Madrid: Espasa Calpe, 1946.

HETHMON, R. H. El método del Actors Studio: conversaciones con Lee Strasberg. Madrid: Editorial Fundamentos, 1986.

IVANOV, V. (org.) Mnemozina - dokuménty i fákty iz istórii otétchestvennogo teatra $X X$ veka - istorítcheski al'manakh výpusk 2 (Mnemozina - documentos e fatos da história nacional do teatro do século XX) Moscou: Editorial URSS, 2000.

JEAGER, W. Paidéia: A Formação do Homem Grego. Tradução de Artur M. Parreira. $2^{a}$ edição. São Paulo: Martins Fontes / Editora Universidade de Brasília, 1989.

__. Aristóteles. Tradução de José Gaos. México: Fondo de Cultura Económica, 1992.

JIMENEZ, S.; CEBALLOS, E. (org.) Técnicas y teorias de la dirección escénica. México: Gaceta, 1988.

JUNG, C. G. O Homem e seus símbolos. Rio de Janeiro: Nova Fronteira, 1987.

KANTOR, T. El teatro de la muerte. Buenos Aires: Ediciones de la Flor, 1984.

KAYSER, W. Interpretación y Análisis de la obra literária. Madrid: Editorial Gredos, 1972. 
KESSELMAN, H; PAVLOVSKY, E. A Multiplicação Dramática. São Paulo: Hucitec, 1991.

KITTO, H. D. F. A Tragédia Grega. Volume I, Tradução de José Manuel Coutinho e Castro. Coimbra/ Portugal: Ed. Arménio Amado, 1990.

A Tragédia Grega. Volume II, Tradução de José Manuel Coutinho e Castro. Coimbra/Portugal: Ed. Arménio Amado, 1990.

LABAN, R. Domínio do Movimento. São Paulo: Summus Editorial, 1978.

LESAGE, A-R. História de Gil Blas de Santillana. Porto Alegre: Mercado Aberto, 1999.

LIMA, L. C. Mimeis e Modernidade - Forma das Sombras. Rio de Janeiro: Graal Ltda, Biblioteca de Teoria Crítica Literária, 1980. Vida e Mimeis. Rio de Janeiro: Ed. 34, 1995.

LUKÁCS, G. Teoria do Romance. Tradução de Alfredo Margarido. Lisboa: Presença, s.d.

. Ontologia do Ser Social: A Falsa e a Verdadeira Ontologia de Hegel. Tradução de Carlos Nelson Coutinho. São Paulo: Ciências Humanas, 1979.

. Estética 1: La Peculiaridad de lo Estético. Tradução de Manuel Sacristán, Vol. 1,2,3 e 4. Barcelona: Grijalbo, 1982.

MARINIS, M. de. Capire il teatro. Firenze: La Casa Usher, 1988.

Mimo e Teatro nel Novecento . Firenze: La Casa Usher, 1993.

_. A cura di, Dramaturgia Dell'Attore. Teatro Eurasiano nº. 3. Porretta Terme. Bolonha: I Quaderni del Battelo Ebbro, 1997.

MIME JOURNAL 1993/1994. Words on Decroux. California: Pomona College Theatre/Department for The Claremont Colleges, 1993.

MIME JOURNAL 1995. Incorporated Knowledge. California: Pomona College Theatre/Department for The Claremont Colleges, 1995.

MIME JOURNAL 1996. Theatre and Sport. California: Pomona College Theatre/Department for The Claremont Colleges, 1996.

MIME JOURNAL 1997. Words on Decroux 2 California: Pomona College Theatre/Department for The Claremont Colleges, 1997.

MIME JOURNAL 2000/2001. An Etienne Decroux Album. California: Pomona College Theatre/Department for The Claremont Colleges, 2001.

MONOD, R. Los Textos de Teatro. La Habana: Editorial Pueblo y Educación, 1989.

OIDA, Y. Um ator errante. São Paulo: Beca Produções Culturais, 1999. . O ator invisível. São Paulo: Beca Produções Culturais, 2001.

OUSPENSKY, P.D. Fragmentos de um Ensinamento Desconhecido. São Paulo: Pensamento, 1987.

PALLOTTINI, R. Dramaturgia, a construção do personagem. São Paulo: Ática, 1989. 
PAVIS, P. Dicionário de Teatro. São Paulo: Perspectiva, 1996.

. A análise dos espetáculos: teatro, mímica, dança, dança-teatro, cinema. São

Paulo: Perspectiva, 2005.

PICON-VALLIN, B. Histoire d'um cheval. In. V. GARCIA, R. WILSON, G. TOVSTONÓGOV, M. ULUSOY, etudes de Odette Aslan, Denis Bablet, Monique Monoy, Catherine Mounies, Béatrice Picon-Vallin. Réunies et présentées par Denis Bablet - Les voies de la creation théâtrale. v. XII. Páginas 176-223. Paris: CNRS, 1984.

PROPP, V. Comicidade e riso. São Paulo: Ática, 1992. . As raízes históricas do conto maravilhoso. São Paulo: Martins Fontes, 2002.

RICHARDS, T. Al lavoro com Grotowski sulle azioni fisiche. Milão: Ubulibri, 1993.

RICOEUR, P. Tempo e Narrativa (tomo 1). Campinas: Papirus, 1994.

REIS, C.; LOPES, A. C. M. Dicionário de Teoria da Narrativa, São Paulo: Ática, 1988.

REVISTA MÁSCARA. La Voz. Ano 2, números 4/5. México, D.F.: Escenologia, 1991. REVISTA MÁSCARA. Ano 3, números 11/12. México, D.F.: 1993.

REVISTA MÁCARA. Ano 4, números 21/22, México, D.F.: Escenologia, 1996.

REVISTA SALA PRETA. Apontamentos sobre o texto teatral contemporâneo, de Sílvia Fernandes; $O$ teatro de origem não-dramaturgica, de José Eduardo Vendramini. Departamento de Artes Cênicas - ECA/USP - ano 1, nº 1, 2001.

REVISTA DE ESTUDOS ORIENTAIS. São Paulo: Humanitas FFLCH/USP, n. 3, dez. 1999.

ROSENFELD, A. O Teatro Épico. São Paulo: Perspectiva,1994.

ROUBINE, J-J. A arte do ator. Rio de Janeiro: Jorge Zahar, 1987. . A Linguagem da Encenação Teatral. Rio de Janeiro: Jorge Zahar, 1998. . Introdução às grandes teorias do teatro. Rio de Janeiro: Jorge Zahar, 2003.

RYNGAERT, J-P. Introdução à análise do teatro. São Paulo: Martins Fontes, 1995. . Ler o Teatro Contemporâneo. São Paulo: Martins Fontes, 1998.

RUFFINI, F. I Teatri di Artaud: crudeltá, corpo-mente. Bologna: Società Editrice il Mulino, 1996.

SÁNCHEZ, J. A. Dramaturgias de la imagen. Múrcia/Cuenca: Grafica Cuencas, 1992/94.

SAVARESE, N. Teatro e Spettacolo fra Oriente e Occidente. Roma: Editori Laterza, 1997.

SCHNAIDERMAN, B. Projeções: Rússia/Brasil/Itália. São Paulo: Perspectiva, 1977. Semiótica Russa. São Paulo: Perspectiva, 1979. 
SHAKESPEARE, W. Romeu e Julieta. Trad. Onestaldo de Pennafort. Porto Alegre: Edição da Livraria do Globo, 1947. . Hamlet. São Paulo: Abril Cultural, 1976.

STAROSÉL’SKAIA, N. Tovstonógov. Moscou: Molodáia Gvárdia, 2004.

STRASBERG, L. Um sonho de Paixão: O desenvolvimento do Método. Rio de Janeiro: Civilização Brasileira, 1990.

SZONDI, P. Teoria do Drama Moderno [1880-1950]. São Paulo: Cosac\&Naify, 2003.

TAVIANI, F. Ryszard Cieslak, in Memorian (1927-1990). In. Revista Máscara, número 16, México: Escenologia, 1994.

TAMÁRTCHENKO, N. D. Teoretitcheskaia poétika: poniatia i opredelenia (Poética teórica: entendimentos e definições). Moscou: ,2001.

TARKOVSKI, A. Esculpir o Tempo. 2a ed., São Paulo: Martins Fontes, 1998.

TODOROV, T. Simbolismo e interpretação. Lisboa: Edições 70, 1978.

TOPORÓV, V. N. Mito, Símbolo, Modelo, pesquisa na área mitopoética, coletânea, Moscou: Ed. do Grupo Progresso Cultura, s/d.

TOUCHARD, P-A. Apologia del teatro. Buenos Aires: Compañia General Fabril Editora, 1961.

VAILLAND, R. Experiência do drama. Porto: Editorial Presença, 1962.

VEINSTEIN, A. La Puesta em escena, Su condición estética. Buenos Aires: Compañia General Fabril Editora, 1962.

VILLAR, J. De la tradición teatral. Buenos Aires: Ediciones Leviatán, 1956.

WAJDA, A. Um cinema chamado desejo. Rio de Janeiro: Campus, 1989.

WEKWERTH, M. Diálogo sobre a encenação, um manual de direção teatral. São Paulo: Hucitec, 1986.

WILLIAMS, R. Tragédia Moderna. São Paulo: Cosac\&Naify, 2002.

WRIGHT, E. A. Para comprender el teatro actual. La Habana: Instituto del Libro, 1969. 
ANEXOS

(material referente à montagem do espetáculo A Dócil) 